\title{
Chemical Synthesis and Biological Evaluations of Adiponectin Collagenous Domain Glycoforms
}

Hongxiang $\mathrm{Wu}^{1, \#}$, Yiwei Zhang ${ }^{2,3, \#}$, Yuanxin $\mathrm{Li}^{2,3, \#}$, Jianchao $\mathrm{Xu}^{1}, \mathrm{Yu}$ Wang ${ }^{2,3,}{ }^{,}$, Xuechen $\mathrm{Li}^{1,{ }^{1,}}$

${ }^{1}$ Department of Chemistry, ${ }^{2}$ State Key Laboratory of Pharmaceutical Biotechnology, and ${ }^{3}$ Department of Pharmacology and Pharmacy, The University of Hong Kong, Hong Kong, P. R. China, SAR.

\#Contributed equally ${ }^{*}$ Corresponding authors: yuwanghk@hku.hk; xuechenl@hku.hk

\section{Supplementary Information}

$\begin{array}{ll}\text { I. General Information } & \text { P2 }\end{array}$

II. Cell Assays and Animal Experiments. $\quad$ P4

III. General Experimental Procedures $\quad$ P8

IV. Synthesis of glycosylated (2S,5R)-hydroxylysine building block $\quad$ P10

$\begin{array}{ll}\text { V. Synthesis of protected salicylaldehyde } & \text { P31 }\end{array}$

VI. Synthesis of adiponectin glycosylated collagen-like peptide analogues $\quad$ P32

VII. $\quad{ }^{1} \mathrm{H}$ and ${ }^{13} \mathrm{C}$ NMR spectra $\quad$ P114 


\section{General Information}

\section{A. Materials and methods and abbreviations}

All commercial materials (Aldrich, Chemimpex, Fluka and GL Biochem) were used without further purification. All solvents were reagent grade or HPLC grade (RCI or DUKSAN). Dry dichloromethane $\left(\mathrm{CH}_{2} \mathrm{Cl}_{2}\right)$ was distilled from calcium hydride $\left(\mathrm{CaH}_{2}\right)$. All reversed-phase (RP) high-performance liquid chromatography (HPLC) separations involved a mobile phase of $0.1 \%$ trifluoroacetic acid (TFA) (v/v) in acetonitrile $\left(\mathrm{CH}_{3} \mathrm{CN}\right) / 0.1 \%$ TFA $(\mathrm{v} / \mathrm{v})$ in water $\left(\mathrm{H}_{2} \mathrm{O}\right)$ were performed with a Waters HPLC system equipped with a photodiode array detector (Waters 2996) using a Vydac 214TPTM C4 column (5 $\mu$, $300 \AA, 4.6 \times 250 \mathrm{~mm}$ ) at a flow rate of $0.6 \mathrm{~mL} / \mathrm{min}$ for analytical HPLC and Vydac 214TPTM C4 column $(10 \mu \mathrm{m}, 300 \AA, 22 \times 250 \mathrm{~mm})$ or Vydac $218 \mathrm{TPTM} \mathrm{C} 18$ column $(10 \mu \mathrm{m}, 300 \AA, 22 \times 250 \mathrm{~mm})$ at a flow rate of $10 \mathrm{~mL} / \mathrm{min}$ for preparative HPLC. Low-resolution mass spectral (MS) analyses were performed with a Waters 3100 mass spectrometer using electrospray ionization (ESI, in positive mode unless otherwise specified). The results were analyzed with Waters Empower software. Calculated masses were based upon the most abundant isotope of a given ion. Analytical TLC was performed on E. Merck silica gel 60 F254 plates and visualized under UV light $(254 \mathrm{~nm})$ or by staining with ninhydrin or $5 \%$ sulfuric acid in ethanol. Silica flash column chromatography was performed on E. Merck 230-400 mesh silica gel 60. ${ }^{1} \mathrm{H}$ and ${ }^{13} \mathrm{C}$ nuclear magnetic resonance (NMR) spectra were recorded at $298 \mathrm{~K}$ on Bruker Avance DRX 300 FT-NMR Spectrometer at $75 \mathrm{MHz}$ for ${ }^{13} \mathrm{C}$ NMR or Bruker Avance DRX 400 FT-NMR spectrometer at $400 \mathrm{MHz}$ for ${ }^{1} \mathrm{H}$ NMR and $100 \mathrm{MHz}$ for ${ }^{13} \mathrm{C}$ NMR or Bruker Avance DRX 600 FT-NMR spectrometer at $150 \mathrm{MHz}$ for ${ }^{13} \mathrm{C}$ NMR. Chemical shifts are reported in parts per million (ppm) and are referenced to solvent residual signals: $\mathrm{CDCl}_{3}(\delta 7.26[1 \mathrm{H}]) .{ }^{1} \mathrm{H}$ NMR data is reported as chemical shift $(\delta)$, relative integral, multiplicity $(\mathrm{s}=$ singlet, $\mathrm{d}=$ doublet, $\mathrm{t}=$ triplet, $\mathrm{dd}=$ doublet of doublets, $\mathrm{td}=$ triplet of doublets), coupling constant $(\mathrm{J} \mathrm{Hz})$. UPLC-MS = Ultra Performance Liquid Chromatography massspectrometry; $\mathrm{PG}=$ protecting groups; $\mathrm{SAL}=$ salicylaldehyde; $\mathrm{DMF}=$ dimethylformamide; $\mathrm{TIPS}=$ 
triisopropylsilane; Mbn = 4-methyl benzyl. For glycosylated 5-hydroxylysine building block coupling, double coupling is required for sufficient conversion (1.2 equiv, $0.1 \mathrm{M}, 6 \mathrm{~h}$, twice). 


\section{Cell Assays and Animal Experiments.}

\section{Animals}

Mice without wild type ADIPOQ alleles (AKO) were maintained on both C57BL/6J and FVB/N background. In metabolic related assays, AKO mice of C57BL/6J background were fed with high-fat diet (19.33 kcal/g from 49.85\% fat, 20\% protein, and 30.15\% carbohydrate; D12451; Research Diet, New Brunswick, NJ, U.S.A.) to induce dietary obesity. For studies related to mammary tumor development, FVB/N-Tg (MMTV-PyVT)634 Mul/J [002374 from Jackson Laboratory (Bar Harbor, ME, U.S.A.)] were cross-bred with AKO of FVB/N background to produce mice without the ADIPOQ alleles (PyVT-AKO). NU/J athymic nude mice (002019) and nonobese diabetic/severe combined immunodeficient NOD.CB17Prkdcscid/J (NOD/SCID; 001303) mice were obtained from the Jackson Laboratory.

\section{Cancer cell proliferative assay}

MDA-MB-231 cells were cultured in DMEM supplemented with 10\% FBS and 1\% penicillinstreptomycin-fungisone at $37^{\circ} \mathrm{C}$ and under $5 \% \mathrm{CO}_{2} 95 \%$ humidified air. After harvested, cells were seeded at a density of 3000 cells per well in 96-well plates and then cultured for 24 hours. After fasting in DMEM with $0.5 \%$ FBS for 24 hours, cells were subsequently stimulated with $2.5 \%$ FBS in the presence of peptides or human adiponectin. The viable cell numbers at 24 hours at different doses were manually counted by mixing with trypan blue dye for analysis. The maximum inhibition rate (Emax) and half maximal effective concentration (EC50) were used to evaluate the anti-tumor activity of peptides and adiponectin.

\section{In vivo anti-tumor activity assay}

All animal care and experimental protocols complied with the institutional guidelines for the care and use of laboratory animals and were approved by the Committee on the Use of Live Animals for Teaching and Research of the University of Hong Kong. All mouse models were housed in a room under the controlled temperature $\left(23 \pm 1^{\circ} \mathrm{C}\right)$ and 12-h light-dark cycles, with free access to water and standard mouse chow If not specifically noted (4.07 kcal/g; LabDiet 5053; LabDiet, Purina Mills, Richmond, VA, U.S.A.). 
Human breast cancer MDA-MB-231 cells were treated with vesicle (PBS) or $20 \mu \mathrm{g} / \mathrm{ml}$ adiponectin glycol-peptides for 24 hours in the absence of fetal bovine serum. A total number of $2 \times 10^{5}$ cells were harvested from each treatment group and injected into the right third mammary fat pad of NOD/SCID mice (six-weeks old, female) and a total number of $5 \times 10^{6}$ cells were harvested from each treatment group and injected in to the right third mammary fat pad of Nude mice (six-weeks old, female). Tumor development was monitored 3 times a week by a digital Vernier caliper by the formula of [sagittal dimension $(\mathrm{mm}) \times$ cross dimension $(\mathrm{mm}) \times 2] / 2$. Mice were sacrificed thirteen days after injection for collecting and weighing tumors and lungs. Data are presented as mean $\pm \mathrm{SEM} ;{ }^{*}, \mathrm{P}<0.05, * *, \mathrm{P}<0.01$ vs corresponding vehicle controls $(n=6)$.

FVB/N-Tg (MMTV-PyVT) 634Mul/J (FVB/N pyvt+/-) adiponectin knocks out (AKO) mice were intraperitoneally injected with $40 \mu \mathrm{g}$ ACD peptide hAdn-WM6877 $(0.4 \mu \mathrm{g} / \mu \mathrm{l}, 100 \mu \mathrm{l})$ or equal volume of PBS per day start from 7-week age, daily injection. Tumor development was monitored every week. Tumor volume was measured using a digital Vernier caliper by the formula of [sagittal dimension $(\mathrm{mm}) \times$ cross dimension $(\mathrm{mm}) \times 2] / 2$. After five weeks injection, mice were sacrificed for collecting and weighing tumors and lungs. Data are presented as mean $\pm \mathrm{SEM}$; $, \mathrm{P}<0.05, * *, \mathrm{P}<0.01$ vs corresponding vehicle controls $(n=6)$.

\section{Metabolic regulative effect of ACD peptide}

ACD peptide hAdn-WM6877 was chose for testing of anti-obesity and insulin-sensitizing functions. WM6877 (40 $\mu \mathrm{g}, 0.4 \mu \mathrm{g} / \mu \mathrm{l}, 100 \mu \mathrm{l})$ or equal volume of PBS was injected into 12-week old C57BL/6J AKO /mice every day for 5 weeks. These mice have been fed with high-fat diet for 8 weeks to induce dietary obesity. Body weight and fat mass composition were measured every week. The body mass composition was assessed using a Bruker minispec Body Composition Analyzer (Bruker Optics, Inc., Woodlands, TX) and all the mice are in conscious and unanesthetized. The intraperitoneal glucose tolerance test (ipGTT) and insulin tolerance test (ITT) were performed using mice that were fasted overnight and for $6 \mathrm{~h}$, respectively. In brief, for ipGTT, mice were given a glucose load by intraperitoneal injection ( $1 \mathrm{~g}$ of glucose/kg of body weight). For ITT, mice were intraperitoneally injected with insulin (1 unit/kg of body weight). Plasma glucose levels were measured at different time points by tail nicking using an Accu-Check Advantage II Glucometer (Roche Diagnostics, Mannheim, Germany). Circulating 
and tissue contents of lipids, including triglycerides, total cholesterols, were analyzed using LiquiColor Triglycerides and Stanbio Cholesterol (Stanbio Laboratory, Boerne, TX) and the Half-Micro Test Kit (Roche Diagnostics), respectively. Metabolic rate $\left(\mathrm{VO}_{2}, \mathrm{VCO}_{2}\right.$, and respiratory exchange ratio [RER]) was measured by indirect calorimetry using a six-chamber open-circuit Oxymax system component of the Comprehensive Laboratory Animal Monitoring System (CLAMS; Columbus Instruments, Columbus, $\mathrm{OH})$. Before recording the data. All mice were acclimatized to the cage for 48 hours.

\section{Histological assay}

After injection of hAdn-WM6877 for 4 weeks AKO mice were sacrificed to collect liver tissues. Tissues were cut into small pieces and fixed in $10 \%$ formalin solution for $48 \mathrm{~h}$ before transferring to $75 \%$ ethanol for long-term storage at $4{ }^{\circ} \mathrm{C}$. The paraffin blocks were prepared for sectioning at $5 \mu \mathrm{m}$ thickness. The tissue slides were stained with hematoxylin and eosin $(H \& E)$ solution. Frozen liver tissues were embedded in Tissue-Tek OCT compound (Sakura ${ }^{\circledR}$ Finetek, CA, U.S.A.), sectioned at $5 \mu \mathrm{m}$ and then stained with Oil Red O (Sigma-Aldrich) for $10 \mathrm{~min}$. All slides were examined under Olympus biological microscope BX41, and images were captured using an Olympus DP72 color digital camera.

\section{Quantitative PCR (QPCR) analysis}

After 8 weeks of HFD, $40 \mu \mathrm{g}$ ADC peptide hAdn-WM6877 $(0.4 \mu \mathrm{g} / \mu \mathrm{l}, 100 \mu \mathrm{l})$ or equal volume of PBS was daily injected into AKO mice. Mice were sacrificed after 5 weeks treatment for collecting liver samples. Total RNA was isolated from liver samples using TRIZOL reagent according to the manufacturer's instructions. Approximately $100 \mathrm{mg}$ were homogenized in $1 \mathrm{ml}$ TRIZOL reagent. After centrifuging $(12,000 \times \mathrm{g})$, supernatants were collected to remove insoluble materials. Then added 200 microliters of chloroform into the homogenate, followed by vigorous shaking and incubated at room temperature for 5 minutes. The mixture was then centrifuged $(12,000 \times \mathrm{g})$ for ten minutes at $4^{\circ} \mathrm{C}$. After centrifugation, $500 \mu \mathrm{l}$ of isopropanol were added to the supernatant. After centrifugation $(12,000 \times \mathrm{g})$ for 10 minutes at $4^{\circ} \mathrm{C}$, using $75 \%$ ethanol to wash the precipitated RNA pellets and then the RNA was dissolved in DEPC water. The concentration of RNA was determined by Gene Quant RNA/DNA calculator at absorbance of 260/280 nm (Pharmacia Biotech, Uppsala, Sweden). After the preparation of samples, QPCR was performed by SYBR Green PCR Master Mix on an ABI PRISM 7900 HT Sequence Detection System (Applied Biosystems, Foster City, CA). The levels of Ribosomal 18S, IL6, IL10, CD68, 
MCP-1 and TNF $\alpha$ genes were detected. The primers used were purchased from RIBOBIO. Quantification was achieved by $\Delta \Delta \mathrm{Ct}$ values that were normalized with GADPH as a reference control. The expression level is calculated by $2^{-\Delta \Delta \mathrm{Ct}}$ for comparison.

\section{Combination index (CI) analysis}

CI is used to determine the mode of drug interaction. To analyze the CI, MDA-MB-31 cells were seeded in 96-well plates to do the chess-board assay. Cells were treated with a concentration of adiponectin ranging from 0 to $2.5 \mu \mathrm{g} / \mathrm{ml}$ and of hAdn-WM or hAdn-WM656877101 ranging from 0 to $20 \mu \mathrm{g} / \mathrm{ml}$ for 24 hours and then cell numbers were counted. CI was calculated by the formula of $\mathrm{CI}=\mathrm{CA}, \mathrm{x} / \mathrm{Cx}, \mathrm{A}+\mathrm{CB}, \mathrm{x} / \mathrm{Cx}, \mathrm{B}$, where $\mathrm{CA}, \mathrm{x}$ and $\mathrm{CB}, \mathrm{x}$ are the concentration of drug $\mathrm{A}$ and $\mathrm{B}$ used in combination to achieve $\mathrm{x} \%$ drug effect (inhibition rate); $\mathrm{Cx}, \mathrm{A}$ and $\mathrm{Cx}, \mathrm{B}$ are the concentrations for single agents to achieve the same effect. A CI of less than, equal to, and more than 1 indicates synergy, additivity, and antagonism, respectively. 


\section{General Experimental Procedures}

\section{A. Fmoc-based Solid-phase Peptide Synthesis (SPPS)}

The solid phase peptide synthesis of peptides/glycopeptides was carried out manually using 2-chlorotrityl resin (CS Biochem, loading: $\sim 0.5 \mathrm{mmol} / \mathrm{g}$ ) unless otherwise specified. 2-chloro-trityl chloride resin was swollen in dry $\mathrm{CH}_{2} \mathrm{Cl}_{2}$ for 30 min then washed with $\mathrm{CH}_{2} \mathrm{Cl}_{2}(5 \times 3 \mathrm{~mL})$. A solution of FmocHN-Xaa$\mathrm{COOH}$ (4.0 equiv. relative to resin capacity) and DIEA (8.0 equiv. relative to resin capacity) in $\mathrm{CH}_{2} \mathrm{Cl}_{2}$ was added and the resin was shaken at room temperature (r. t.) for 2 h. The resin was washed with DMF $(5 \times 3 \mathrm{~mL})$ and $\mathrm{CH}_{2} \mathrm{Cl}_{2}(5 \times 3 \mathrm{~mL})$. The resin was treated with a solution of $\mathrm{CH}_{2} \mathrm{Cl}_{2} / \mathrm{CH}_{3} \mathrm{OH} / \mathrm{DIEA}$ $(17: 2: 1, \mathrm{v} / \mathrm{v} / \mathrm{v}, 3 \mathrm{~mL})$ for $1 \mathrm{~h}$ to cap the unreacted sites, and was washed sequentially with $\mathrm{DMF}(5 \times 3 \mathrm{~mL})$, $\mathrm{CH}_{2} \mathrm{Cl}_{2}(5 \times 3 \mathrm{~mL})$, and DMF $(5 \times 3 \mathrm{~mL})$. The resin was subsequently submitted to iterative peptide assembly (Fmoc-SPPS). The following Fmoc amino acids and Boc amino acids from GL Biochem were employed: FmocHN-Ala-COOH, FmocHN-Cys(Trt)-COOH, FmocHN-Cys(StBu)-COOH, FmocHNAsp(OtBu)-COOH, FmocHN-Glu(OtBu)-COOH, FmocHN-Phe-COOH, FmocHN-Gly-COOH, FmocHN-His(Trt)-COOH, FmocHN-Ile-COOH, FmocHN-Lys(Boc)-COOH, FmocHN-Leu-COOH, FmocHN-Met-COOH， FmocHN-Asn(Trt)-COOH， FmocHN-Pro-COOH，FmocHN-Gln(Trt)-COOH, FmocHN-Arg(Pbf)-COOH, FmocHN-Ser(tBu)-COOH, FmocHN-Thr(tBu)-COOH, FmocHN-Val-COOH, FmocHN-Trp(Boc)-COOH, FmocHN-Tyr(tBu)-COOH. For the Fmoc removal step, the resin was treated with the deblock solution (20\% piperidine in DMF) at room temperature for $15 \mathrm{~min}$. The resin was then washed sequentially with DMF $(5 \times 3 \mathrm{~mL}), \mathrm{CH}_{2} \mathrm{Cl}_{2}(5 \times 3 \mathrm{~mL})$, and DMF $(5 \times 3 \mathrm{~mL})$. For the coupling step, a solution of Fmoc protected amino acid (2.0 equiv. according to the resin capacity), HATU (2.0 equiv.) and DIEA (5.0 equiv.) in DMF was gently agitated with the resin at room temperature for $40 \mathrm{~min}$. The resin was washed with DMF $(5 \times 3 \mathrm{~mL}), \mathrm{CH}_{2} \mathrm{Cl}_{2}(5 \times 3 \mathrm{~mL})$, and DMF $(5 \times 3 \mathrm{~mL})$. This procedure was repeated twice for coupling each amino acid. For the glycosylated lysine coupling step, a solution of Fmoc protected amino acid (1.5 equiv. according to the resin capacity), HATU (1.5 equiv.) and DIEA 
(3.0 equiv.) in DMF was gently agitated with the resin at room temperature for $8 \mathrm{~h}$. The resin was washed with DMF $(5 \times 3 \mathrm{~mL}), \mathrm{CH}_{2} \mathrm{Cl}_{2}(5 \times 3 \mathrm{~mL})$, and DMF $(5 \times 3 \mathrm{~mL})$. This procedure was repeated twice.

\section{B. Cleavage of crude protected peptide bearing the free carboxylic acid at the C-terminus from resin with Cocktail A}

The on-resin fully protected peptidyl acid, obtained as described in the previous section, was subjected to mild acidic cleavage cocktail (5 - $10 \mathrm{~mL})$ of $\mathrm{CH}_{2} \mathrm{Cl}_{2} / \mathrm{AcOH} /$ trifluoroethanol $(8 / 1 / 1, \mathrm{v} / \mathrm{v} / \mathrm{v}), 3$ times for 60 min each. Following filtration, the resulting cleavage solutions were combined and concentrated to give crude protected peptide bearing the free carboxylic acid at the C-terminus. 


\section{Synthesis of glycosylated $(2 S, 5 R)$-hydroxylysine building block}

\section{Part 1. Synthesis of L-a-vinylglycine (Compound 1.3)}

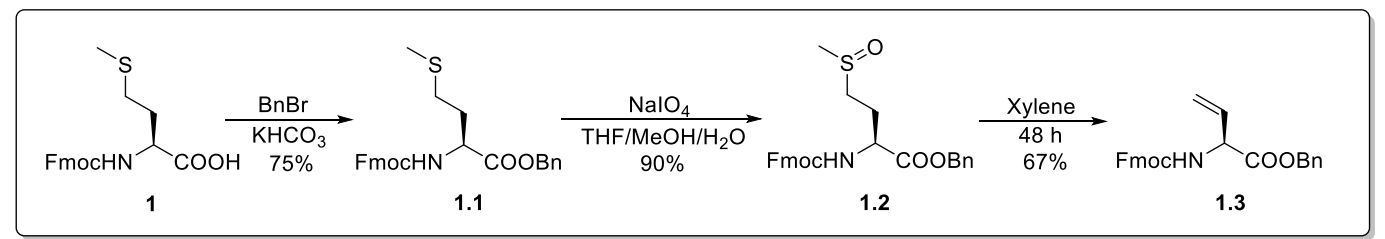

\section{Scheme S1. Synthesis of L-a-vinylglycine}

\section{Compound 1.1:}

$\mathrm{KHCO}_{3}(13.5 \mathrm{~g}, 134.60 \mathrm{mmol}, 2.5$ equiv.) was slowly added to the mixture of Fmoc-Met-OH 1 (20.0 g, $53.80 \mathrm{mmol}, 1.0$ equiv.), $\mathrm{BnBr}(13.7 \mathrm{~g}, 80.70 \mathrm{mmol}, 1.5$ equiv.) in anhydrous $\mathrm{DMF}(50 \mathrm{~mL})$. The reaction mixture was stirred at room temperature for $4 \mathrm{~h}$. Till the full conversion of the acid $\mathbf{1}$, the reaction mixture was diluted with EtOAc $(500 \mathrm{~mL})$ and washed sequentially with $1 \mathrm{~N} \mathrm{HCl}(3 \times 100 \mathrm{~mL})$ and brine $(100 \mathrm{~mL})$. The organic phase was dried over $\mathrm{Na}_{2} \mathrm{SO}_{4}$ and concentrated under vacuum. Purification by silica gel chromatography $(n$-hexane/EtOAc $=6: 1)$ gave Fmoc-Met-OBn 1.1 (18.6 g, 75\%) as a white solid.

${ }^{1} \mathrm{H}$ NMR (400 MHz, $\left.\mathrm{CDCl}_{3}\right), \delta=7.75(2 \mathrm{H}, \mathrm{d}, J=7.5 \mathrm{~Hz}), 7.57(2 \mathrm{H}, \mathrm{d}, J=7.5 \mathrm{~Hz}), 7.26-7.40(9 \mathrm{H}, \mathrm{m})$, $5.46(1 \mathrm{H}, \mathrm{d}, J=8.0 \mathrm{~Hz}), 5.19(2 \mathrm{H}, \mathrm{dd}, J=8.0 \mathrm{~Hz}, 9.2 \mathrm{~Hz}), 5.05(1 \mathrm{H}, \mathrm{dd}, J=12.6 \mathrm{~Hz}), 4.41(2 \mathrm{H}, \mathrm{d}, J=$ $6.9 \mathrm{~Hz}), 4.21(1 \mathrm{H}, \mathrm{t}, J=6.9 \mathrm{~Hz}), 2.37-2.50(2 \mathrm{H}, \mathrm{m}), 2.20-2.31(1 \mathrm{H}, \mathrm{m}), 2.04(3 \mathrm{H}, \mathrm{s}), 1.94-2.04(1 \mathrm{H}, \mathrm{m})$.

${ }^{13} \mathrm{C}$ NMR $\left(100 \mathrm{MHz}, \mathrm{CDCl}_{3}\right), \delta=171.7,155.7,143.7,143.5,141.1,135.0,128.5,128.2,127.5,126.3$, $124.9,119.8,67.2,66.8,53.1,46.9,31.6,29.5,15.2$.

HRMS (ESI+) for $\mathrm{C}_{27} \mathrm{H}_{27} \mathrm{NNaO}_{4} \mathrm{~S}(+)[\mathrm{M}+\mathrm{Na}]+$ : calcd 484.1558; found 484.1552. 


\section{Compound 1.2:}

$\mathrm{NaIO}_{4}\left(8.6 \mathrm{~g}, 40.3 \mathrm{mmol}, 1.0\right.$ equiv) in $\mathrm{H}_{2} \mathrm{O}(20 \mathrm{~mL})$ was slowly added to the mixture of $\mathbf{1 . 1}(18.6 \mathrm{~g}, 40.3$ mmol, 1.0 equiv.) in $\mathrm{MeOH}(200 \mathrm{~mL})$ and THF (40 mL) in ice bath. The cooling bath was then removed and the mixture was stirred overnight. After full conversion was achieved, the reaction mixture was concentrated under vacuum. The residue was diluted with DCM $(500 \mathrm{~mL})$ and washed with $1 \mathrm{~N} \mathrm{HCl}(2 \times$ $100 \mathrm{~mL})$ and brine $(100 \mathrm{~mL})$. The organic phase was dried over anhydrous $\mathrm{Na}_{2} \mathrm{SO}_{4}$ and concentrated under vacuum. Purification by silica gel chromatography $\left(\mathrm{CH}_{2} \mathrm{Cl}_{2} / \mathrm{MeOH}=18: 1\right)$ gave 1.2 (17.3 g, 90\%) as a white solid.

${ }^{1} \mathrm{H}$ NMR $\left(400 \mathrm{MHz}, \mathrm{CDCl}_{3}\right), \delta=7.75(2 \mathrm{H}, \mathrm{d}, J=7.5 \mathrm{~Hz}), 7.59(2 \mathrm{H}, \mathrm{s}), 7.30-7.41(9 \mathrm{H}, \mathrm{m}), 5.91-5.99$ $(1 \mathrm{H}, \mathrm{m}), 5.19(2 \mathrm{H}, \mathrm{dd}, J=12.3 \mathrm{~Hz}, 18.5 \mathrm{~Hz}), 4.50-4.52(1 \mathrm{H}, \mathrm{m}), 4.40(2 \mathrm{H}, \mathrm{dd}, J=6.6 \mathrm{~Hz}, 11.4 \mathrm{~Hz}), 4.19$ $(1 \mathrm{H}, \mathrm{t}, J=6.5 \mathrm{~Hz}), 2.64-2.70(2 \mathrm{H}, \mathrm{m}), 2.48(3 \mathrm{H}, \mathrm{d}, J=6.3 \mathrm{~Hz}), 2.37-2.42(1 \mathrm{H}, \mathrm{m}), 2.15-2.19(1 \mathrm{H}, \mathrm{m})$.

${ }^{13} \mathrm{C}$ NMR $\left(100 \mathrm{MHz}, \mathrm{CDCl}_{3}\right), \delta=171.0,156.0,143.7,143.5,141.1,134.8,128.6,128.3,127.6,127.0$, $119.8,67.5,66.9,53.0,52.8,50.0,49.9,47.0,38.4,25.9,25.5$.

HRMS (ESI+) for $\mathrm{C}_{27} \mathrm{H}_{27} \mathrm{NNaO}_{5} \mathrm{~S}(+)$ [M+Na]+: calcd 500.1508; found 500.1517.

\section{Compound 1.3:}

The compound 1.2 (17.3 g, $36.2 \mathrm{mmol})$ was refluxed in xylene $(250 \mathrm{~mL})$ for $24 \mathrm{~h}$. After full conversion, the solvent was removed under vacuum and the residue was purified by silica gel chromatography $(n$ hexane/EtOAc $=7: 1)$ to afford $\mathbf{1 . 3}$ as a light yellow solid $(10.0 \mathrm{~g}, 67 \%){ }^{1}$

${ }^{1} \mathrm{H}$ NMR (400 MHz, $\left.\mathrm{CDCl}_{3}\right), \delta=7.78(2 \mathrm{H}, \mathrm{d}, J=7.5 \mathrm{~Hz}), 7.61(2 \mathrm{H}, \mathrm{d}, J=7.5 \mathrm{~Hz}), 7.28-7.42(9 \mathrm{H}, \mathrm{m})$, 5.85-6.06 (1H, m), $5.51(1 \mathrm{H}, \mathrm{d}, J=7.3 \mathrm{~Hz}), 5.29-5.38(2 \mathrm{H}, \mathrm{m}), 5.23(2 \mathrm{H}, \mathrm{s}), 5.20(1 \mathrm{H}, \mathrm{m}), 5.44(2 \mathrm{H}, \mathrm{d}, J$ $=6.8 \mathrm{~Hz}), 4.25(1 \mathrm{H}, \mathrm{t}, J=6.8 \mathrm{~Hz})$.

${ }^{13} \mathrm{C} \mathrm{NMR}\left(100 \mathrm{MHz}, \mathrm{CDCl}_{3}\right), \delta=170.2,155.5,143.7,143.6,141.2,135.0,132.1,128.5,128.4,128.1$, 127.6, 127.0, 125.0, 119.9, 117.8, 67.4, 67.0, 56.1, 47.0. 


\section{Part 2. Synthesis of Boc-4-amine-3-(R)-hydroxyl-1-butene (Compound 2.3-1)}

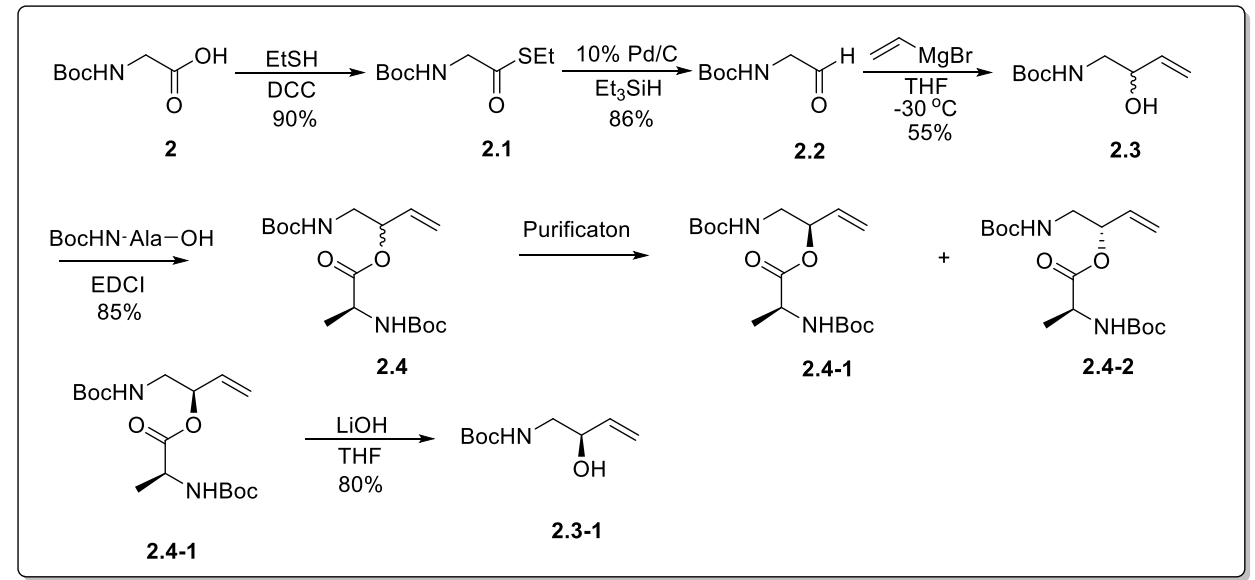

Scheme S2. Synthesis of compound 2.3-1 via chiral resolution approach.

\section{Compound 2.1:}

DMAP (418.3 mg, 3.42 mmol, 0.1 equiv.) was added to the solution of Boc-Gly-OH 2 (6.0 g, 34.20 mmol, 1.0 equiv.), EtSH ( $5 \mathrm{~mL}, 68.50 \mathrm{mmol}, 2.0$ equiv.) and DCC (7.0 g, $34.2 \mathrm{mmol}, 1.0$ equiv.) in anhydrous $\mathrm{CH}_{2} \mathrm{Cl}_{2}$ under argon. The reaction mixture was stirred at room temperature for $4 \mathrm{~h}$. After full conversion, the white suspension was filtrated through celite and the filtrate was concentrated under vacuum. The residue was purified by silica gel chromatography ( $n$-hexane/EtOAc $=5: 1)$ to give $\mathbf{2 . 1}$ as a colorless oil $(6.7 \mathrm{~g}, 90 \%)$.

${ }^{1} \mathrm{H}$ NMR (400 MHz, $\left.\mathrm{CDCl}_{3}\right), \delta 5.11(\mathrm{~s}, 1 \mathrm{H}), 4.06(\mathrm{~d}, J=6.0 \mathrm{~Hz}, 2 \mathrm{H}), 2.93(\mathrm{q}, J=7.4 \mathrm{~Hz}, 2 \mathrm{H}), 1.48$ (s, 9H), $1.28(\mathrm{t}, J=7.4 \mathrm{~Hz}, 3 \mathrm{H})$.

${ }^{13} \mathrm{C}$ NMR $\left(100 \mathrm{MHz}, \mathrm{CDCl}_{3}\right), \delta$ 198.5, 155.4, 80.3, 50.2, 28.5, 23.2, 14.9.

HRMS (FAB) for $\mathrm{C}_{7} \mathrm{H}_{14} \mathrm{NO}_{3}$ : calcd 160.0895; found 160.0889 .

\section{Compound 2.2:}

$\mathrm{Et}_{3} \mathrm{SiH}(7.20 \mathrm{~mL}, 45.6 \mathrm{mmol}, 2.0$ equiv) was slowly added to the mixture of compound 2.1 (5.0 g, 22.80 mmol, 1.0 equiv.) and $10 \% \mathrm{Pd} / \mathrm{C}(500.0 \mathrm{mg})$ in anhydrous DCM under argon. The reaction mixture was 
stirred at room temperature for $3 \mathrm{~h}$, then was filtered through celite. The filtrate was concentrated under vacuum and the residue was purified by flash silica gel chromatography ( $n$-hexane/EtOAc $=3: 1)$ to give 2.2 as a colorless oil $(3.2 \mathrm{~g}, 86 \%)$.

${ }^{1} \mathrm{H}$ NMR (400 MHz, $\left.\mathrm{CDCl}_{3}\right), \delta 9.58(\mathrm{~s}, 1 \mathrm{H}), 5.41(\mathrm{~s}, 1 \mathrm{H}), 3.99$ (d, J=5.2 Hz, 2H), 1.40 (s, 9H).

${ }^{13} \mathrm{C}$ NMR (100 MHz, $\left.\mathrm{CDCl}_{3}\right), \delta 197.7,155.8,80.0,51.2,28.2$.

HRMS (CI+) for $\mathrm{C}_{7} \mathrm{H}_{13} \mathrm{NO}_{3}$ : calcd 159.0895; found 159.0892.

\section{Compound 2.3:}

Under argon protection, vinylmagnesium bromide solution (1M in THF, $24.7 \mathrm{~mL}, 2.0$ equiv.) was added into a $100 \mathrm{~mL}$ round bottom flask. The solution was cooled to $-30{ }^{\circ} \mathrm{C}$, then the solution of compound $\mathbf{2 . 2}$ (1.8 g, $12.40 \mathrm{mmol}, 1.0$ equiv.) in anhydrous THF $(20 \mathrm{~mL})$ was added. The resultant solution was stirred at $-30{ }^{\circ} \mathrm{C}$ for $2 \mathrm{~h}$, then the saturated $\mathrm{NH}_{4} \mathrm{Cl}$ aqueous solution $(20 \mathrm{~mL})$ was added slowly to quench the reaction. THF was evaporated under vacuum, and the residue was diluted with EtOAc $(150 \mathrm{~mL})$. The organic phase was washed with water $(2 \times 30 \mathrm{~mL})$ and brine $(30 \mathrm{~mL})$. The organic phase was dried over anhydrous $\mathrm{Na}_{2} \mathrm{SO}_{4}$. The residue was purified by silica gel chromatography $(n$-hexane/EtOAc $=3: 1)$ to give $\mathbf{2 . 3}$ as a colorless oil (1.1 $\mathrm{g}, 55 \%)$.

${ }^{1} \mathrm{H}$ NMR $\left(400 \mathrm{MHz}, \mathrm{CDCl}_{3}\right): \delta=5.83(1 \mathrm{H}, \mathrm{ddd}, J=5.7 \mathrm{~Hz}, 6.5 \mathrm{~Hz}, 12.2 \mathrm{~Hz}), 5.33(1 \mathrm{H}, \mathrm{d}, J=14.6 \mathrm{~Hz})$, $5.18(1 \mathrm{H}, \mathrm{d}, J=11.7 \mathrm{~Hz}), 5.16(1 \mathrm{H}, \mathrm{m}), 4.22(1 \mathrm{H}, \mathrm{m}), 3.28-3.37(2 \mathrm{H}, \mathrm{m}), 3.06-3.08(1 \mathrm{H} . \mathrm{m}), 1.44(9 \mathrm{H}$, s).

${ }^{13} \mathrm{C} \mathrm{NMR}\left(100 \mathrm{MHz}, \mathrm{CDCl}_{3}\right): \delta=156.7,138.0,116.1,79.6,72.2,46.2,28.4$.

HRMS (CI+) for $\mathrm{C}_{9} \mathrm{H}_{18} \mathrm{O}_{3} \mathrm{~N}$ : calcd 188.1286; found 188.1282. 


\section{Compound 2.4:}

DMAP (44.6 mg, $0.36 \mathrm{mmol}, 0.1$ equiv.) was added to the solution of 2.3 ( $0.7 \mathrm{~g}, 3.65 \mathrm{mmol}, 1.0$ equiv.), Boc-Ala-OH (1.05 g, $5.45 \mathrm{mmol}, 1.5$ equiv.) and EDCI (1.4 g, $7.25 \mathrm{mmol}, 2.0$ equiv.) in anydrous DCM $(15 \mathrm{~mL})$ under argon. The reaction mixture was stirred at room temperature for $8 \mathrm{~h}$, then was diluted with ethyl acetate $(200 \mathrm{~mL})$ and washed sequentially with $1 \mathrm{~N} \mathrm{HCl}(2 \times 30 \mathrm{~mL})$ and brine $(30 \mathrm{~mL})$. The organic phase was dried over anhydrous $\mathrm{Na}_{2} \mathrm{SO}_{4}$ and concentrated under vacuum. The residue was purified by silica gel chromatography $(n$-hexane/EtOAc $=7: 1)$ to give the compound 2.4-1 (lower polarity, $0.51 \mathrm{~g}, 40 \%$ ) and compound $\mathbf{2 . 4 - 2}$ (higher polarity, $0.57 \mathrm{~g}, 45 \%$ ).

Compound 2.4-1: ${ }^{1} \mathrm{H}$ NMR (400 MHz, CDCl3): $\delta=5.77(1 \mathrm{H}, \mathrm{ddd}, J=6.1 \mathrm{~Hz}, 10.6 \mathrm{~Hz}, 17.0 \mathrm{~Hz})$, 5.29-5.35 (3H, m), $5.02(1 \mathrm{H}, \mathrm{d}, J=5.6 \mathrm{~Hz}), 4.91(1 \mathrm{H}, \mathrm{s}), 4.28(1 \mathrm{H}, \mathrm{t}, J=6.1 \mathrm{~Hz}), 3.45(1 \mathrm{H}, \mathrm{m})$, 3.23-3.27 (1H, m), $1.44(9 \mathrm{H}, \mathrm{s}), 1.43(9 \mathrm{H}, \mathrm{s}), 1.40(3 \mathrm{H}, \mathrm{d}, J=11.3 \mathrm{~Hz})$.

${ }^{13} \mathrm{C}$ NMR $\left(100 \mathrm{MHz}, \mathrm{CDCl}_{3}\right): \delta=172.4,156.0,155.4,133.1,118.6,80.1,79.6,74.6,49.7,43.6,28.4$, 18.4. HRMS (ESI+) for $\mathrm{C}_{17} \mathrm{H}_{30} \mathrm{~N}_{2} \mathrm{NaO}_{6}(+)[\mathrm{M}+\mathrm{Na}]+$ : calcd 381.1996; found 381.2002.

Compound 2.4-2: ${ }^{1} \mathrm{H}$ NMR (400 MHz, $\left.\mathrm{CDCl}_{3}\right): \delta=5.77(1 \mathrm{H}, \mathrm{ddd}, J=5.8 \mathrm{~Hz}, 10.6 \mathrm{~Hz}, 16.9 \mathrm{~Hz})$, 5.24-5.37 (3H, m), 5.00-5.03 (2H, m), $4.26(1 \mathrm{H}, \mathrm{t}, J=6.6 \mathrm{~Hz}), 3.20-3.27(1 \mathrm{H}, \mathrm{m}), 1.44(9 \mathrm{H}, \mathrm{s}), 1.42$ $(9 \mathrm{H}, \mathrm{s}), 1.38(3 \mathrm{H}, \mathrm{d}, J=7.2 \mathrm{~Hz})$.

${ }^{13} \mathrm{C}$ NMR $\left(100 \mathrm{MHz}, \mathrm{CDCl}_{3}\right): \delta 172.7,156.0,155.3,133.2,118.5,80.2,79.7,74.8,49.6,43.8 .28 .5,18.3$. HRMS (ESI+) for $\mathrm{C}_{17} \mathrm{H}_{30} \mathrm{~N}_{2} \mathrm{NaO}_{6}(+)$ [M+Na]+: calcd 381.1996; found 381.2002.

\section{Compound 2.3-1:}

$1 \mathrm{M}$ aqueous lithium hydroxide (36.7 $\mathrm{mg}, 0.90 \mathrm{mmol}, 3.0$ equiv.) was added to the solution of compound 2.4-1 (100.0 mg, $0.30 \mathrm{mmol}, 1.0$ equiv.) in THF at room temperature. The mixture was stirred for $4 \mathrm{~h}$ and extracted with ethyl acetate $(3 \times 30 \mathrm{~mL})$. The combined organic phase was washed with aqueous sodium bicarbonate $(30 \mathrm{~mL})$ and brine $(20 \mathrm{~mL})$, and dried over anhydrous $\mathrm{Na}_{2} \mathrm{SO}_{4}$. The organic phase was 
concentrated under vacuum, and the residue was purified by silica gel chromatography ( $n$-hexane/EtOAc $=2.5: 1)$ to give the $\mathbf{2 . 3}-\mathbf{1}$ as a colorless oil $(40.3 \mathrm{mg}, 92 \%)$.

${ }^{1} \mathrm{H}$ NMR (400 MHz, $\left.\mathrm{CDCl}_{3}\right), \delta=5.83(1 \mathrm{H}, \mathrm{ddd}, J=5.7 \mathrm{~Hz}, 6.5 \mathrm{~Hz}, 12.2 \mathrm{~Hz}), 5.33(1 \mathrm{H}, \mathrm{d}, J=14.6 \mathrm{~Hz})$, $5.18(1 \mathrm{H}, \mathrm{d}, J=11.7 \mathrm{~Hz}), 5.16(1 \mathrm{H}, \mathrm{m}), 4.22(1 \mathrm{H}, \mathrm{m}), 3.28-3.37(2 \mathrm{H}, \mathrm{m}), 3.06-3.08(1 \mathrm{H} . \mathrm{m}), 1.44(9 \mathrm{H}$, s).

${ }^{13} \mathrm{C} \mathrm{NMR}\left(100 \mathrm{MHz}, \mathrm{CDCl}_{3}\right): \delta=156.8,138.0,116.1,79.6,72.2,46.2,28.4$.

$[\alpha]_{\mathrm{D}}^{25}=-2.69^{\circ}\left(c=1.40, \mathrm{CHCl}_{3}\right)$

HRMS (CI+) for $\mathrm{C}_{9} \mathrm{H}_{18} \mathrm{O}_{3} \mathrm{~N}$ : calcd 188.1286; found 188.1282.

Part 3. Synthesis of 2.3-1 by using 2.4-2

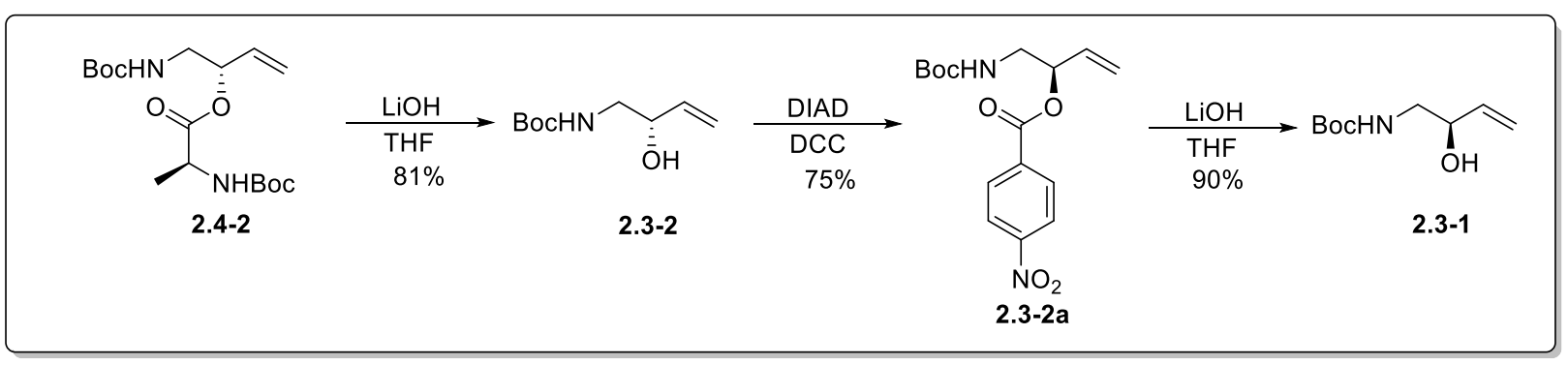

Scheme S3. Synthesis of 2.3-1 by using 2.4-2

\section{Compound 2.3-2:}

The $1 \mathrm{M}$ aqueous lithium hydroxide $(36.7 \mathrm{mg}, 0.90 \mathrm{mmol}, 3.0$ equiv.) solution was added to the solution of compound 2.4-2 (100 mg, $0.30 \mathrm{mmol}, 1.0$ equiv.) in THF at room temperature. The mixture was stirred overnight and extracted with ethyl acetate $(3 \times 30 \mathrm{~mL})$. The combined organic phase was washed with aqueous sodium bicarbonate $(30 \mathrm{~mL})$ and brine $(20 \mathrm{~mL})$, and dried over anhydrous $\mathrm{Na}_{2} \mathrm{SO}_{4}$. The organic 
phase was concentrated under vacuum and purified by silica gel chromatography $(n$-hexane/EtOAc $=$ 2.5:1) to give $\mathbf{2 . 3 - 2}$ as a colorless oil $(40.7 \mathrm{mg}, 81 \%)$.

${ }^{1} \mathrm{H}$ NMR (400 MHz, $\left.\mathrm{CDCl}_{3}\right): \delta=5.83(1 \mathrm{H}, \mathrm{ddd}, J=5.7 \mathrm{~Hz}, 6.5 \mathrm{~Hz}, 12.2 \mathrm{~Hz}), 5.33(1 \mathrm{H}, \mathrm{d}, J=14.6 \mathrm{~Hz})$, $5.18(1 \mathrm{H}, \mathrm{d}, J=11.7 \mathrm{~Hz}), 5.16(1 \mathrm{H}, \mathrm{m}), 4.22(1 \mathrm{H}, \mathrm{m}), 3.28-3.37(2 \mathrm{H}, \mathrm{m}), 3.06-3.08(1 \mathrm{H} . \mathrm{m}), 1.44(9 \mathrm{H}$, s).

${ }^{13} \mathrm{C} \mathrm{NMR}\left(100 \mathrm{MHz}, \mathrm{CDCl}_{3}\right), \delta=156.8,138.0,116.1,79.6,72.2,46.2,28.4$.

HRMS (CI+) for $\mathrm{C}_{9} \mathrm{H}_{18} \mathrm{O}_{3} \mathrm{~N}$ : calcd 188.1286; found 188.1281.

\section{Compound 2.3-2a:}

To a stirred solution of compound $\mathbf{2 . 3 - 2}$ (100 mg, $0.50 \mathrm{mmol}, 1.0$ equiv.), triphenylphosphine (168 $\mathrm{mg}$, $0.60 \mathrm{mmol}, 1.2$ equiv.) and $p$-nitrobenzoic acid (107 $\mathrm{mg}, 0.60 \mathrm{mmol}, 1.2$ equiv.) in anhydrous THF at 0 ${ }^{\circ} \mathrm{C}$, was added diisopropyl azodicarboxylate $(126 \mu \mathrm{L}, 0.60 \mathrm{mmol}, 1.2$ equiv.). The reaction mixture was gradually warmed to room temperature and allowed to be stirred for $1 \mathrm{~h}$. The solution was then concentrated under vacuum, and the residue was purified by silica gel chromatography ( $n$-hexane/EtOAc $=5: 1)$ to give $2.3-2 \mathrm{a}$ as a yellow solid $(134.8 \mathrm{mg}, 75 \%)$.

${ }^{1} \mathrm{H}$ NMR (400 MHz, $\left.\mathrm{CDCl}_{3}\right): \delta=8.30(2 \mathrm{H}, \mathrm{dd}, J=1.9 \mathrm{~Hz}, 6.9 \mathrm{~Hz}), 8.23(2 \mathrm{H}, \mathrm{dd}, J=2.1 \mathrm{~Hz}, 6.9 \mathrm{~Hz})$, $5.88(1 \mathrm{H}, \mathrm{ddd}, J=6.1 \mathrm{~Hz}, 10.5 \mathrm{~Hz}, 17.0 \mathrm{~Hz}), 5.57(1 \mathrm{H}, \mathrm{dd}, J=6.0 \mathrm{~Hz}, 11.3 \mathrm{~Hz}), 5.30-5.45(2 \mathrm{H}, \mathrm{m}), 4.74$ $(1 \mathrm{H}, \mathrm{s}), 3.48-3.55(2 \mathrm{H}, \mathrm{m}), 1.44(9 \mathrm{H}, \mathrm{s})$.

${ }^{13} \mathrm{C}$ NMR $\left(100 \mathrm{MHz}, \mathrm{CDCl}_{3}\right): \delta=164.0,155.9,150.8,135.6,133.1,131.0,123.7,119.2,79.9,75.6,43.6$, 28.4.

HRMS (ESI+) for $\mathrm{C}_{16} \mathrm{H}_{20} \mathrm{~N}_{2} \mathrm{NaO}_{6}(+)[\mathrm{M}+\mathrm{Na}]+$ : calcd 359.1214; found 359.1213. 


\section{Compound 2.3-1:}

The $1 \mathrm{M}$ aqueous lithium hydroxide (63 mg, $1.50 \mathrm{mmol}, 3.6$ equiv.) was added to the solution of compound 2.3-2a (135 mg, $0.42 \mathrm{mmol}, 1.0$ equiv.) in THF at room temperature. The mixture was stirred for $4 \mathrm{~h}$ and extracted with ethyl acetate $(3 \times 30 \mathrm{~mL})$. The combined organic phase was washed with aqueous sodium bicarbonate $(30 \mathrm{~mL})$ and brine $(20 \mathrm{~mL})$, and dried over anhydrous $\mathrm{Na}_{2} \mathrm{SO}_{4}$. The organic phase was concentrated under vacuum and purified by silica gel chromatography $(n$-hexane/EtOAc $=$ 2.5:1) to give 2.3-1 as a colorless oil (50.1 $\mathrm{mg}, 90 \%)$.

Part 4. Synthesis of (2S,5R)-hydroxylysine building block (Compound 4)

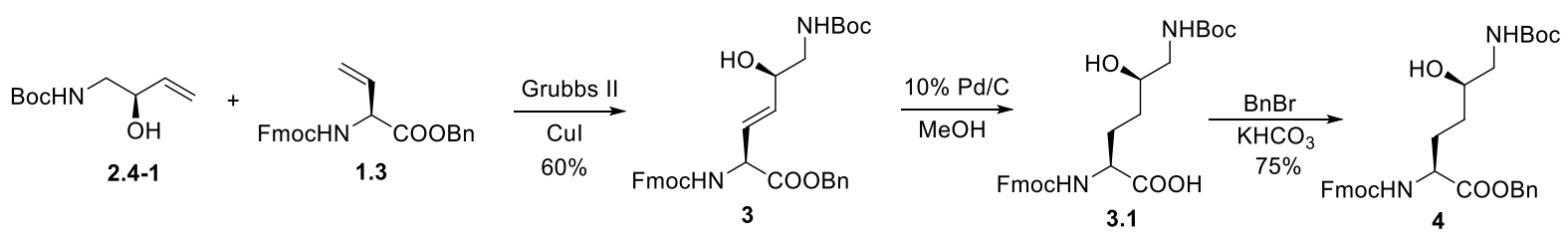

Scheme S4. Synthesis of (2S,5R)-hydroxylysine building block

\section{Compound 3:}

Grubbs II catalyst ( $88 \mathrm{mg}, 0.10 \mathrm{mmol}, 0.019$ equiv.) and CuI (102 mg, $0.53 \mathrm{mmol}, 0.1$ equiv.) were added to a flame-dried flask equipped with a condenser, and anhydrous diethyl ether $(10 \mathrm{~mL})$ was added. Compound 2.4-1 (1.00 g, 5.33 mmol, 1.0 equiv.) and compound 1.3 (4.40 g, 10.74 mmol, 2.0 equiv.) were dissolved in anhydrous diethyl ether $(15 \mathrm{~mL})$, and this solution was added via syringe to the above flask. The mixture was refluxed for $12 \mathrm{~h}$. After full conversion of 2.4-1, the mixture was concentrated 
under vacuum and purified by silica gel chromatography ( $n$-hexane/EtOAc $=2: 1)$ to give $\mathbf{3}$ as a brown solid $(1.80 \mathrm{~g}, 60 \%)$.

${ }^{1} \mathrm{H}$ NMR (400 MHz, $\left.\mathrm{CDCl}_{3}\right): \delta=7.76(2 \mathrm{H}, \mathrm{d}, J=7.5 \mathrm{~Hz}), 7.59(2 \mathrm{H}, \mathrm{d}, J=7.2 \mathrm{~Hz}), 7.25-7.42(9 \mathrm{H}, \mathrm{m})$, $5.84(1 \mathrm{H}, \mathrm{dd}, J=4.7 \mathrm{~Hz}, 8.7 \mathrm{~Hz}), 5.76(1 \mathrm{H}, \mathrm{dd}, J=5.1 \mathrm{~Hz}, 8.7 \mathrm{~Hz}), 5.54(1 \mathrm{H}, \mathrm{d}, J=7.5 \mathrm{~Hz}), 5.19(2 \mathrm{H}, \mathrm{s})$, $4.97(1 \mathrm{H}, \mathrm{m}), 4.85(1 \mathrm{H}, \mathrm{s}), 4.39(2 \mathrm{H}, \mathrm{dd}, J=2.32 \mathrm{~Hz}, 10.0 \mathrm{~Hz}), 4.19-4.23(2 \mathrm{H}, \mathrm{m}), 3.15-3.25(1 \mathrm{H}, \mathrm{m})$, 2.95-3.05 (1H, m), $1.43(9 \mathrm{H}, \mathrm{s})$.

${ }^{13} \mathrm{C}$ NMR (100 MHz, CDCl3), $\delta=170.7,157.1,156.0,144.0,141.5,136.2,134.0,128.9,128.7,128.5$, $128.0,127.4,127.0,126.3,120.2,80.0,71.3,67.8,67.4,55.6,47.3,46.4,28.6$.

HRMS (ESI+) for $\mathrm{C}_{33} \mathrm{H}_{36} \mathrm{~N}_{2} \mathrm{O}_{7} \mathrm{Na}(+)$ [M + Na]+: calcd 595.2415; found 595.2408.

\section{Compound 4:}

Compound 3 (1.80 g, $3.15 \mathrm{mmol}, 1.0$ equiv.) and catalytic amount of $\mathrm{Pd} / \mathrm{C}$ (208 mg) were mixed with ethyl acetate $(20 \mathrm{~mL})$. The mixture was stirred under $\mathrm{H}_{2}$ atmosphere at r.t. for $5 \mathrm{~h}$. After full conversion of $\mathbf{3}$, the reaction mixture was filtered through celite, and the filtrate was concentrated under vacuum, to give the yellow solid. The crude product compound 3.1 was used in the next step without further purification.

The crude compound 3.1 was dissolved in anhydrous DMF $(10 \mathrm{~mL})$ at room temperature, then the $\mathrm{KHCO}_{3}(710 \mathrm{mg}, 7.10 \mathrm{mmol}, 2.3$ equiv.) and benzyl bromide $(621 \mu \mathrm{L}, 5.31 \mathrm{mmol}, 1.7$ equiv.) were added. The mixture was stirred at room temperature for $4 \mathrm{~h}$. The solution was diluted with $1 \mathrm{~N} \mathrm{HCl} \mathrm{(50}$ $\mathrm{mL})$ and extracted with EtOAc $(3 \times 100 \mathrm{~mL})$. The combined organic phase was washed with brine $(50$ $\mathrm{mL}$ ) and dried over anhydrous $\mathrm{Na}_{2} \mathrm{SO}_{4}$. The solution was concentrated under vacuum, and the residue was purified by silica gel chromatography ( $n$-hexanes/EtOAc $=2: 1)$ to give 4 as a white solid $(1.40 \mathrm{~g}, 75 \%)$.

${ }^{1} \mathrm{H}$ NMR (400 MHz, $\left.\mathrm{CDCl}_{3}\right): \delta=7.76(2 \mathrm{H}, \mathrm{d}, J=7.5 \mathrm{~Hz}), 7.63(2 \mathrm{H}, \mathrm{d}, J=7.5 \mathrm{~Hz}), 7.25-7.41(9 \mathrm{H}, \mathrm{m})$, $5.63(1 \mathrm{H}, \mathrm{d}, J=5.3 \mathrm{~Hz}), 5.14-5.22(2 \mathrm{H}, \mathrm{m}), 4.91(1 \mathrm{H}, \mathrm{s}), 4.33-4.45(3 \mathrm{H}, \mathrm{m}), 4.20(1 \mathrm{H}, \mathrm{t}, J=6.8 \mathrm{~Hz})$, 
$3.66(1 \mathrm{H}, \mathrm{s}), 3.19(1 \mathrm{H}, \mathrm{m}), 2.96(1 \mathrm{H}, \mathrm{t}, J=6.2 \mathrm{~Hz}), 2.02-2.06(1 \mathrm{H}, \mathrm{m}), 1.75-1.80(1 \mathrm{H}, \mathrm{m}), 1.43(2 \mathrm{H}, \mathrm{m})$, $1.43(9 \mathrm{H}, \mathrm{d})$.

${ }^{13} \mathrm{C} \mathrm{NMR}\left(100 \mathrm{MHz}, \mathrm{CDCl}_{3}\right): \delta=172.3,157.1,156.3,144.0,143.8,141.4,135.3,128.8,128.7,127.8$, $127.2,125.2,120.1,79.9,71.2,67.4,67.2,53.8,47.3,46.7,30.3,29.2,28.5$.

HRMS (ESI+) for $\mathrm{C}_{33} \mathrm{H}_{38} \mathrm{~N}_{2} \mathrm{NaO}_{7}(+)[\mathrm{M}+\mathrm{Na}]^{+}$: calcd 597.2571; found 597.2571.

Part 5. Synthesis of glycosylated (2S,5R)-hydroxylysine building block (Compound 11)

\section{Synthesis of Compound 5.1a}

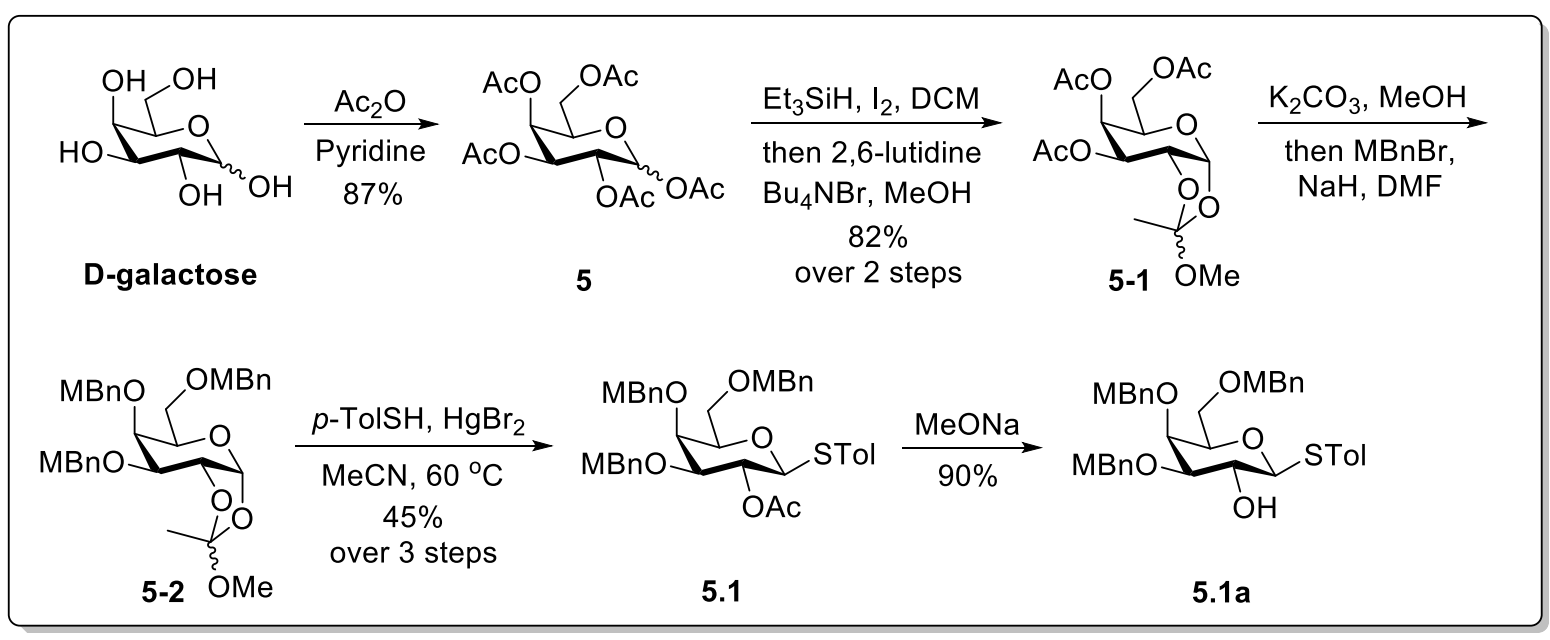

Scheme S5. Synthesis of thiogalactoside acceptor

\section{Compound 5.1:}

Acetic anhydride (15.0 mL, $112.5 \mathrm{mmol}, 7.5$ equiv.) was added to a stirred slurry of D-galactose 3.4 (2.70 $\mathrm{g}, 15.0 \mathrm{mmol}, 1.0$ equiv. $)$ in anhydrous pyridine $(10 \mathrm{~mL})$ at room temperature, followed by catalytic amount of DMAP (183 mg, $1.47 \mathrm{mmol}, 0.1$ equiv.). The mixture was stirred at room temperature for $4 \mathrm{~h}$, then the solvent was evaporated under vacuum. The residue was diluted with EtOAc $(250 \mathrm{~mL})$, washed 
sequentially with $1 \mathrm{~N} \mathrm{HCl}(3 \times 40 \mathrm{~mL})$, saturated $\mathrm{NaHCO}_{3}(2 \times 40 \mathrm{~mL})$, and brine $(2 \times 40 \mathrm{~mL})$. The organic phase was dried over $\mathrm{Na}_{2} \mathrm{SO}_{4}$ and concentrated under vacuum to give crude compound $\mathbf{5}$ as a colorless oil (5.10 g, 87\%), which was directly used without further purification.

i) The crude compound 5 (1.00 g, $2.51 \mathrm{mmol}, 1.0$ equiv.) was dissolved in anhydrous $\mathrm{CH}_{2} \mathrm{Cl}_{2}(8 \mathrm{~mL})$. To the above solution were added $\mathrm{I}_{2}(912 \mathrm{mg}, 3.62 \mathrm{mmol}, 1.5$ equiv.) and triethylsilane $(571 \mu \mathrm{L}, 3.60 \mathrm{mmol}$, 1.5 equiv.). The mixture was refluxed until complete consumption of peracetylated sugar as indicated by TLC. The solution was then cooled to room temperature and subjected to the next step without workup.

ii) To the above reaction mixture were sequentially added 2,6-lutidine (1.20 mL, $10.2 \mathrm{mmol}, 4.0$ equiv.), anhydrous methanol $(600 \mu \mathrm{L}, 15.4 \mathrm{mmol}, 6.1$ equiv.) and tetrabutylammonium bromide $(330 \mathrm{mg}, 1.0$ mmol, 0.4 equiv.). The mixture was stirred overnight at room temperature. When full conversion was achieved, the mixture was concentrated under vacuum, and the residue was purified by silica gel chromatography $(n$-hexane/EtOAc $=5: 1)$ to give compound 5-1 as a colorless oil $(758 \mathrm{mg}, 82 \%$ over 2 steps).

iii) The compound 5-1 (758 mg, $2.11 \mathrm{mmol}, 1.0$ equiv.) was dissolved in $\mathrm{MeOH}(4 \mathrm{~mL})$, then $\mathrm{K}_{2} \mathrm{CO}_{3}(58$ mg, 0.42 mmol, 0.2 equiv.) was added. The above mixture was stirred at room temperature for $2 \mathrm{~h}$. After completion of the reaction, the solvent was evaporated under vacuum and the resulting residue was redissolved in the dry DMF (4 mL). To the above solution was slowly added $\mathrm{NaH}$ (418.6 mg, $10.55 \mathrm{mmol}$, 5.0 equiv.) at $0{ }^{\circ} \mathrm{C}$, and the resulting mixture was stirred for $15 \mathrm{~min}$, followed by addition of $\mathrm{BnBr}(1.20$ $\mathrm{mL}, 10.53 \mathrm{mmol}, 5.0$ equiv.) slowly. The mixture was stirred at room temperature for $6 \mathrm{~h}$ until full conversion. The reaction was quenched by saturated $\mathrm{NH}_{4} \mathrm{Cl}$ aqueous solution $(30 \mathrm{~mL})$, and then extracted by EtOAc $(3 \times 40 \mathrm{~mL})$. The combined organic phase was washed with brine $(30 \mathrm{~mL})$ and dried over anhydrous $\mathrm{Na}_{2} \mathrm{SO}_{4}$. The solvent was concentrated under vacuum and the resulting crude product compound 5-2 was subjected to the next step without further purification. 
iv) The crude compound 5-2 was dissolved in anhydrous acetonitrile $(8 \mathrm{~mL})$, then $p$-toluenethiol $(1.30 \mathrm{~g}$, $10.55 \mathrm{mmol}, 1.0$ equiv.) and $\mathrm{HgBr}_{2}$ (76 mg, $0.21 \mathrm{mmol}, 0.02$ equiv.) were added. The reaction mixture was stirred at $60{ }^{\circ} \mathrm{C}$ for $5 \mathrm{~h}$, then was concentrated under vacuum. The residue was purified by silica gel chromatography $(n$-hexane/EtOAc $=5: 1)$ to give compound $\mathbf{5 . 1}$ as a white solid $(602 \mathrm{mg}, 45 \%$ over 2 steps).

${ }^{1} \mathrm{H}$ NMR (400 MHz, $\left.\mathrm{CDCl}_{3}\right): \delta=7.41(2 \mathrm{H}, \mathrm{d}, J=8.1 \mathrm{~Hz}), 7.13-7.22(12 \mathrm{H}, \mathrm{m}), 7.05(2 \mathrm{H}, \mathrm{d}, J=8.0 \mathrm{~Hz})$, $5.41(1 \mathrm{H}, \mathrm{t}, J=9.8 \mathrm{~Hz}), 4.91(1 \mathrm{H}, \mathrm{d}, J=11.4 \mathrm{~Hz}), 4.65(1 \mathrm{H}, \mathrm{d}, J=12 \mathrm{~Hz}), 4.50-4.59(3 \mathrm{H}, \mathrm{m}), 4.41(2 \mathrm{H}$, $\mathrm{q}, J=11.4 \mathrm{~Hz}), 3.97(2 \mathrm{H}, \mathrm{d}, J=2.5 \mathrm{~Hz}), 3.58-3.66(3 \mathrm{H}, \mathrm{m}), 3.54(1 \mathrm{H}, \mathrm{dd}, J=2.7 \mathrm{~Hz}, 9.6 \mathrm{~Hz}), 2.37-2.39$ (9H, m), $2.33(3 \mathrm{H}, \mathrm{s}), 2.09(3 \mathrm{H}, \mathrm{s})$.

${ }^{13} \mathrm{C} \mathrm{NMR}\left(100 \mathrm{MHz}, \mathrm{CDCl}_{3}\right): \delta=169.52,137.54,137.49,137.09,135.52,134.91,134.88,132.35,129.97$, $129.53,129.12,129.10,128.85,128.22,128.10,127.63,87.13,81.25,77.68,77.29,74.13,73.47,72.40$, $71.74,69.87,68.73,21.22,21.21,21.15,21.13$.

HRMS (ESI+) for $\mathrm{C}_{39} \mathrm{H}_{44} \mathrm{NaO}_{6} \mathrm{~S}(+)[\mathrm{M}+\mathrm{Na}]^{+}$: calcd 663.2756; found 663.2749.

\section{Compound 5.1a}

The compound 5.1 (602 mg, $0.94 \mathrm{mmol}, 1.0$ equiv.) was dissolved in $\mathrm{MeOH}$ (10 mL), then 25\% $\mathrm{NaOMe}$ in $\mathrm{MeOH}(90 \mu \mathrm{L}, 0.30 \mathrm{mmol}, 0.3$ equiv.) was added. The reaction mixture was stirred at room temperature for $6 \mathrm{~h}$, and was quenched by HOAc $(30 \mu \mathrm{L})$. The resulting mixture was diluted with ethyl acetate $(150 \mathrm{~mL})$ and washed with $\mathrm{H}_{2} \mathrm{O}(20 \mathrm{~mL})$ and brine $(20 \mathrm{~mL})$. The organic phase was dried over anhydrous $\mathrm{Na}_{2} \mathrm{SO}_{4}$ and concentrated under vacuum. The residue was purified by silica gel chromatography $(n$-hexane/EtOAc $=4: 1)$ to give compound 5.1 as a white solid $(507 \mathrm{mg}, 90 \%)$.

${ }^{1} \mathrm{H}$ NMR (400 MHz, $\left.\mathrm{CDCl}_{3}\right): \delta=7.48(2 \mathrm{H}, \mathrm{d}, J=8.0 \mathrm{~Hz}), 7.27(2 \mathrm{H}, \mathrm{d}, J=7.9 \mathrm{~Hz}), 7.14-7.23(10 \mathrm{H}, \mathrm{m})$, $7.05(2 \mathrm{H}, \mathrm{d}, J=8.0 \mathrm{~Hz}), 4.87(1 \mathrm{H}, \mathrm{d}, J=11.4 \mathrm{~Hz}), 4.73(1 \mathrm{H}, \mathrm{d}, J=11.7 \mathrm{~Hz}), 4.62(1 \mathrm{H}, \mathrm{d}, J=11.7 \mathrm{~Hz})$, 
$4.56(1 \mathrm{H}, \mathrm{d}, J=11.3 \mathrm{~Hz}), 4.42-4.52(3 \mathrm{H}, \mathrm{m}), 3.98(2 \mathrm{H}, \mathrm{q}, J=9.6 \mathrm{~Hz}), 3.63-3.68(3 \mathrm{H}, \mathrm{m}), 3.46(1 \mathrm{H}, \mathrm{dd}$, $J=2.5 \mathrm{~Hz}, 9.2 \mathrm{~Hz}), 2.39(6 \mathrm{H}, \mathrm{s}), 2.38(3 \mathrm{H}, \mathrm{s}), 2.34(3 \mathrm{H}, \mathrm{s})$.

${ }^{13} \mathrm{C}$ NMR $\left(100 \mathrm{MHz}, \mathrm{CDCl}_{3}\right): \delta=137.69,137.62,137.56,137.05,135.70,134.99,134.88,132.77,129.61$, $129.25,129.14,128.84,128.13,127.99,127.87,88.77,83.08,77.65,74.19,73.47,72.76,72.14,69.00$, $68.61,21.23,21.16$.

HRMS (ESI+) for $\mathrm{C}_{37} \mathrm{H}_{42} \mathrm{NaO}_{5} \mathrm{~S}(+)[\mathrm{M}+\mathrm{Na}]^{+}$: calcd 621.2651; found 621.2641. 


\section{Optimization of glycosylation condition}

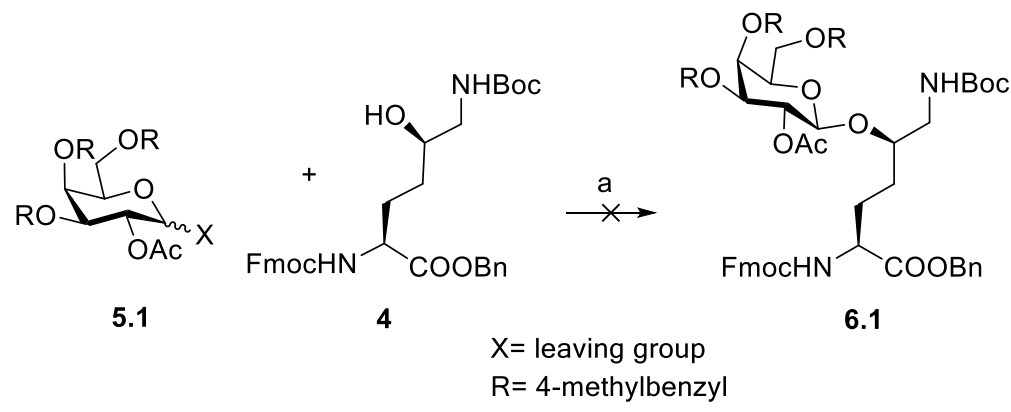

\begin{tabular}{|c|c|c|c|}
\hline & Glycosylation donor & Condition & Result \\
\hline 1 & ${ }_{\mathrm{OAc}}^{\mathrm{MBnO}} \mathrm{NHB}_{\mathrm{NH}}^{\mathrm{OMBn}} \mathrm{CCl}_{3}$ & $\begin{array}{c}\text { TBSOTf, }-40{ }^{\circ} \mathrm{C} \\
\text { DCM, flame-dried } 4 \AA \text { molecular } \\
\text { sieves }\end{array}$ & $\begin{array}{c}\text { Orthoester } \\
(42 \%)\end{array}$ \\
\hline 2 & ${ }_{\mathrm{OAc}}^{\mathrm{MBnO}} \mathrm{N}_{\mathrm{NH}}^{\mathrm{OMBn}} \mathrm{CCl}_{3}$ & $\begin{array}{c}\text { TMSOTf, }-40{ }^{\circ} \mathrm{C} \\
\text { DCM, flame-dried } 4 \AA \text { molecular } \\
\text { sieves }\end{array}$ & $\begin{array}{c}\text { Orthoester } \\
(38 \%)\end{array}$ \\
\hline 3 & $\underbrace{\mathrm{OMBn}}_{\mathrm{OAc}}$ & $\begin{array}{c}\text { NIS, TMSOTf, }-78^{\circ} \mathrm{C} \\
\text { DCM, flame-dried } 4 \AA \text { molecular } \\
\text { sieves }\end{array}$ & $\begin{array}{c}\text { Orthoester } \\
(32 \%)\end{array}$ \\
\hline 4 & $\underbrace{\mathrm{OMBn}}_{\mathrm{OAC}}$ & $\begin{array}{c}\text { NIS, TMSOTf, }-78^{\circ} \mathrm{C} \\
\text { DCM, flame-dried } 4 \AA \text { molecular } \\
\text { sieves }\end{array}$ & $\begin{array}{c}\text { Orthoester } \\
(29 \%)\end{array}$ \\
\hline 5 & $\underbrace{\mathrm{OMBn}}_{\mathrm{OAC}} \mathrm{SPh}$ & $\begin{array}{c}\text { PhSCl, AgOTf, }-78^{\circ} \mathrm{C} \\
\text { DCM, flame-dried } 4 \AA \text { molecular } \\
\text { sieves }\end{array}$ & $\begin{array}{c}\text { Orthoester } \\
(36 \%)\end{array}$ \\
\hline
\end{tabular}




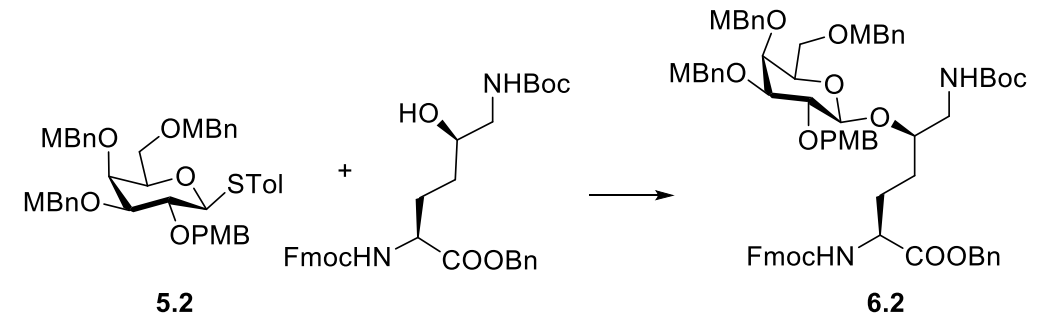

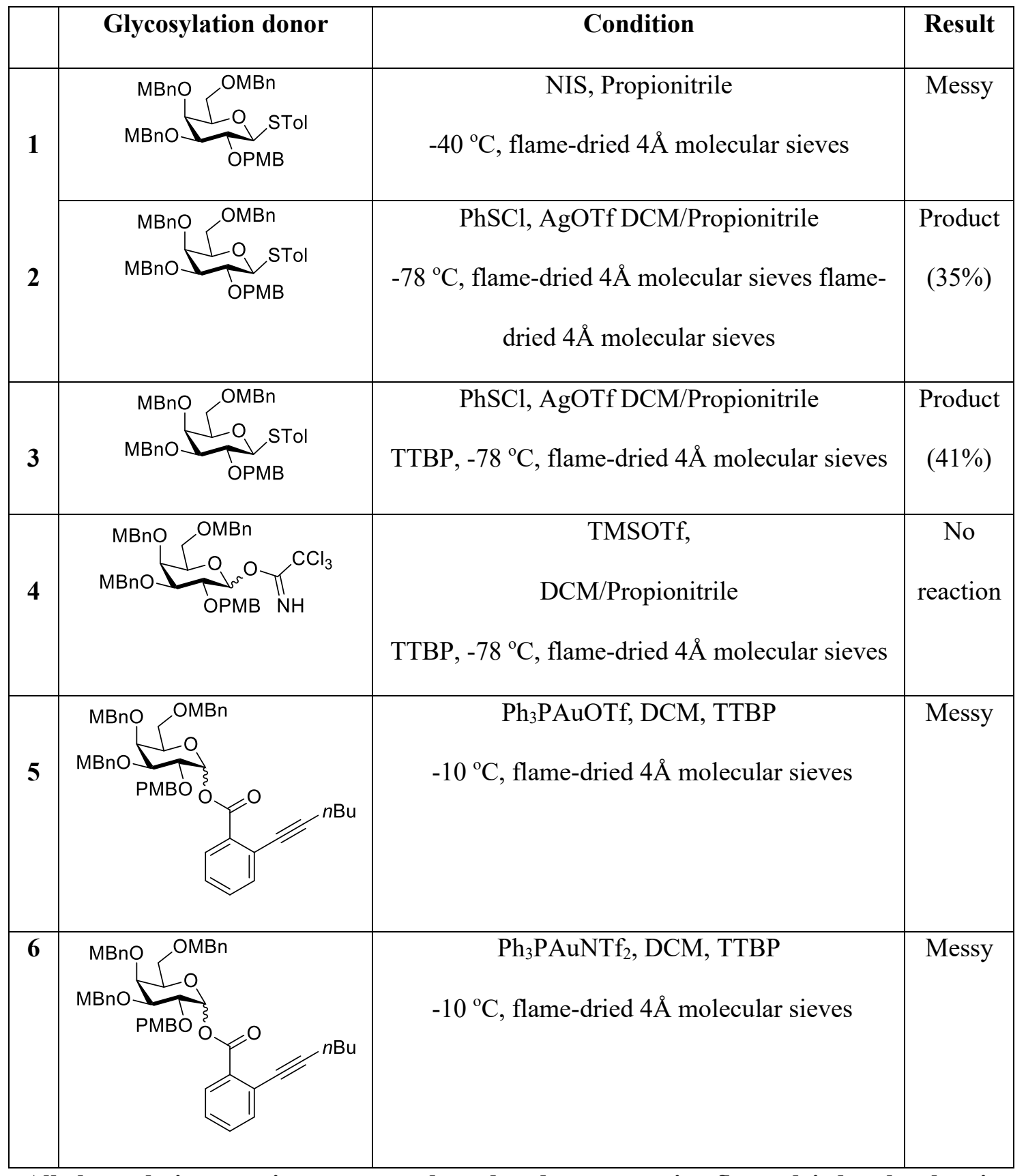

Note: All glycosylation reactions were conducted under argon using flame-dried molecular sieves. 


\section{Synthesis of disaccharide 9}

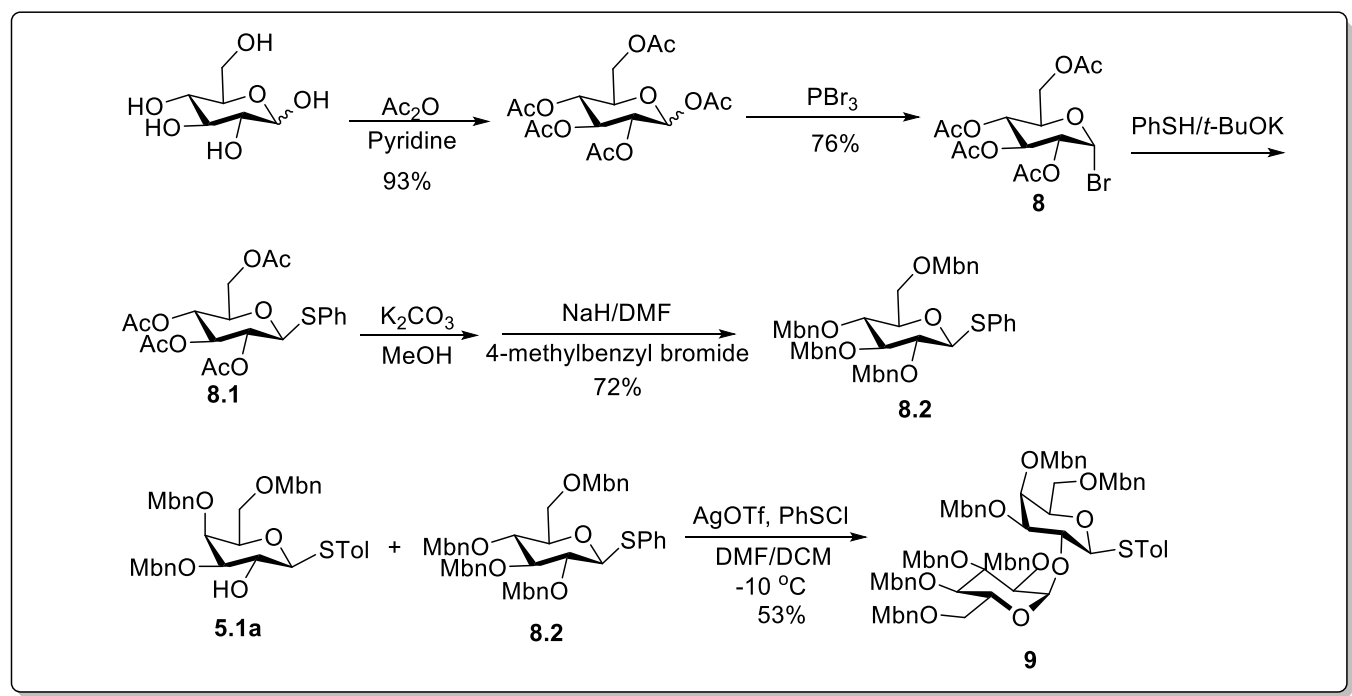

\section{Scheme S6. Synthesis of disaccharide 9}

\section{Compound 8.2:}

i) Acetic anhydride (39.0 mL, $417 \mathrm{mmol}, 7.5$ equiv.) was added to a stirred slurry of D-glucose $\mathbf{3 . 2 6}$ (10.0 g, $55.6 \mathrm{mmol}, 1.0$ equiv.) in anhydrous pyridine (34.0 mL, $417 \mathrm{mmol}, 7.5$ equiv.) at room temperature, followed by catalytic amount of DMAP $(677 \mathrm{mg}, 5.6 \mathrm{mmol}, 0.1$ equiv.). The mixture was stirred at room temperature for $12 \mathrm{~h}$, then ethanol $(10 \mathrm{~mL})$ was added and stirred for another $1 \mathrm{~h}$ to quench the excess amount of acetic anhydride. The solvent was evaporated under vacuum, and the residue was diluted with EtOAc $(500 \mathrm{~mL})$. The organic phase was washed with $1 \mathrm{~N} \mathrm{HCl}(3 \times 80 \mathrm{~mL})$, saturated $\mathrm{NaHCO}_{3}(2 \times 80$ $\mathrm{mL})$, and brine $(2 \times 80 \mathrm{~mL})$. The organic phase was then dried over $\mathrm{Na}_{2} \mathrm{SO}_{4}$ and concentrated under vacuum to give glucose petaacetate as a white solid $(20.1 \mathrm{~g}, 93 \%)$.

ii) The glucose pentaacetate $(20.1 \mathrm{~g}, 51.3 \mathrm{mmol}, 1.0$ equiv. $)$ was dissolved in HOAc $(50 \mathrm{~mL})$ under ice bath, then $\mathrm{PBr}_{3}\left(7.6 \mathrm{~mL}, 78.8 \mathrm{mmol}, 1.5\right.$ equiv.) was slowly added. To this mixture, $\mathrm{H}_{2} \mathrm{O}(4.4 \mathrm{~mL}, 239$ mmol, 4.6 equiv.) was added slowly in $30 \mathrm{~min}$. The reaction mixture was stirred at room temperature for $3 \mathrm{~h}$. After full conversion of material, the mixture was diluted with $n$-hexane/ $\mathrm{CH}_{2} \mathrm{Cl}_{2}=2: 1(800 \mathrm{~mL}$ in total), and sequentially washed with ice water $(500 \mathrm{~mL})$, saturated $\mathrm{NaHCO}_{3}(2 \times 300 \mathrm{~mL})$, and brine $(500$ 
$\mathrm{mL}$ ). The organic phase was dried over $\mathrm{Na}_{2} \mathrm{SO}_{4}$ and concentrated under vacuum to give glucosyl bromide 8 intermediate as a colorless oil $(16.0 \mathrm{~g}, 76 \%)$. The crude product was used in the next step without further purification.

iii) Potassium tert-butoxide ( $4.37 \mathrm{~g}, 38.9 \mathrm{mmol}, 1.0$ equiv.) was added to the solution of $\mathrm{PhSH}(4.0 \mathrm{~mL}$, 38.9 mmol, 1.0 equiv.) in anhydrous $\mathrm{THF}(50 \mathrm{~mL})$ at $0{ }^{\circ} \mathrm{C}$. The reaction mixture was stirred at room temperature for $0.5 \mathrm{~h}$, then compound 8 (16.0 g, $38.9 \mathrm{mmol}, 1.0$ equiv.) in THF (50 mL) was slowly added. After full conversion of $\mathbf{8}$, the reaction mixture was diluted with EtOAc $(800 \mathrm{~mL})$, and washed with $\mathrm{H}_{2} \mathrm{O}(3 \times 400 \mathrm{~mL})$ and brine $(2 \times 400 \mathrm{~mL})$. The organic phase was dried over $\mathrm{Na}_{2} \mathrm{SO}_{4}$ and concentrated under vacuum. The residue was purified by silica gel chromatography $(n$-hexane/EtOAc $=$ 2.5:1) to give compound $\mathbf{8 . 1}$ as a white solid (15.2 g, 90\%).

iv) $\mathrm{K}_{2} \mathrm{CO}_{3}$ (952 mg, $6.9 \mathrm{mmol}, 0.2$ equiv.) was added to the solution of compound $\mathbf{8 . 1}$ (15.2 $\mathrm{g}, 34.5 \mathrm{mmol}$, 1.0 equiv.) in $\mathrm{MeOH}(100 \mathrm{~mL})$. The reaction was stirred at room temperature for $2 \mathrm{~h}$. After full conversion of the material, the solvent was evaporated under vacuum, and the residue was re-dissolved in anhydrous DMF (80 mL). The $\mathrm{NaH}$ (60\% dispersed in mineral oil) (6.90 g, $172.5 \mathrm{mmol}, 5.0$ equiv.) was added slowly to this solution, and the resulting slurry was stirred for $30 \mathrm{~min}$ at $0{ }^{\circ} \mathrm{C}$. To this slurry, The $4-$ methylbenzyl bromide ( $32.0 \mathrm{~g}, 172.5 \mathrm{mmol}, 5.0$ equiv.) was slowly added, and the mixture was stirred at room temperature overnight. The mixture was diluted with EtOAc $(1000 \mathrm{~mL})$, and washed with $1 \mathrm{~N} \mathrm{HCl}$ $(3 \times 400 \mathrm{~mL})$ and brine $(2 \times 400 \mathrm{~mL})$. The organic phase was dried over anhydrous $\mathrm{Na}_{2} \mathrm{SO}_{4}$ and concentrated under vacuum. The residue was purified by silica gel chromatography $(n$-hexane/EtOAc $=$ 6:1) to give compound 8.2 as a white solid (17.1g, $72 \%)$.

${ }^{1} \mathrm{H} \operatorname{NMR}\left(400 \mathrm{MHz}, \mathrm{CDCl}_{3}\right): \delta=7.59-7.62(2 \mathrm{H}, \mathrm{m}), 7.31(2 \mathrm{H}, \mathrm{d}, J=7.9 \mathrm{~Hz}), 7.22-7.27(7 \mathrm{H}, \mathrm{m})$, 7.14-7.18 (6H, m), $7.10(4 \mathrm{H}, \mathrm{q}, J=8.3 \mathrm{~Hz}), 4.85(3 \mathrm{H}, \mathrm{m}), 4.70-4.80(2 \mathrm{H}, \mathrm{m}), 4.66(1 \mathrm{H}, \mathrm{d}, J=9.8 \mathrm{~Hz})$, 4.50-4.61 (3H, m), 3.67-3.79 (3H, m), $3.62(1 \mathrm{H}, \mathrm{t}, J=9.4), 2.38(3 \mathrm{H}, \mathrm{s}), 2.37(6 \mathrm{H}, \mathrm{s}), 2.35(3 \mathrm{H}, \mathrm{s})$. 
${ }^{13} \mathrm{C}$ NMR $\left(100 \mathrm{MHz}, \mathrm{CDCl}_{3}\right): \delta=137.59,137.53,137.40,137.22,135.47,135.24,135.07,133.97,131.91$, $129.14,129.11,129.09,129.02,128.88,128.38,128.13,128.13,127.98,127.84,127.36,87.50,86.64$, $80.69,79.10,77.66,77.24,75.72,75.28,74.92,73.28,68.82,21.23,21.21$.

HRMS (ESI+) for $\mathrm{C}_{44} \mathrm{H}_{48} \mathrm{NaO}_{5} \mathrm{~S}(+)[\mathrm{M}+\mathrm{Na}]^{+}$: calcd 711.3120; found 711.3112.

\section{Compound 9:}

Compound 8.2 (1.03 g, $1.50 \mathrm{mmol}, 1.5$ equiv.) and flame-dried molecular sieve (AW-300) was suspended in anhydrous $\mathrm{CH}_{2} \mathrm{Cl}_{2}(25 \mathrm{~mL})$. Then, DMF (462 $\mu \mathrm{L}, 6.00 \mathrm{mmol}, 6.0$ equiv.) was added to the mixture. The resulting mixture was stirred at room temperature for $10 \mathrm{~min}$ and at $-10{ }^{\circ} \mathrm{C}$ for an additional $10 \mathrm{~min}$. Subsequently, AgOTf (385 mg, $1.50 \mathrm{mmol}, 1.5$ equiv.) was added, and then phenylsulfenylchloride (217 mg, 1.50 mmol, 1.5 equiv.) was slowly added. Upon completion of the activation of glycosyl donor $\mathbf{8 . 2}$, thioglycoside acceptor 5.1a (599 mg, $1.00 \mathrm{mmol}$, 1.0 equiv.) was added to the reaction mixture, and the mixture was stirred at $-10{ }^{\circ} \mathrm{C}$ overnight. The mixture was then diluted with EtOAc $(300 \mathrm{~mL})$, and washed by $1 \mathrm{~N} \mathrm{HCl}(3 \times 50 \mathrm{~mL})$ and brine $(100 \mathrm{~mL})$. The organic phase was dried over anhydrous $\mathrm{Na}_{2} \mathrm{SO}_{4}$ and concentrated under vacuum. The residue was purified by silica gel chromatography $(n$-hexane/EtOAc $=$ 6:1) to give compound 9 as a colorless oil (624 mg, 53\%).

${ }^{1} \mathrm{H}$ NMR (400 MHz, $\left.\mathrm{CDCl}_{3}\right): \delta=7.41(2 \mathrm{H}, \mathrm{d}, J=8.2 \mathrm{~Hz}), 7.24-7.28(4 \mathrm{H}, \mathrm{m}), \quad 7.15-7.20(12 \mathrm{H}, \mathrm{m})$, $7.06-7.14(8 \mathrm{H}, \mathrm{m}), 6.98(4 \mathrm{H}, \mathrm{t}, J=8.6 \mathrm{~Hz}), 6.88(2 \mathrm{H}, \mathrm{d}, J=7.8 \mathrm{~Hz}), 5.78(1 \mathrm{H}, \mathrm{d}, J=3.8 \mathrm{~Hz}), 4.88-4.97$ $(3 \mathrm{H}, \mathrm{m}), 4.80(3 \mathrm{H}, \mathrm{t}, J=9.6 \mathrm{~Hz}), 4.66-4.75(3 \mathrm{H}, \mathrm{m}), 4.49-4.57(2 \mathrm{H}, \mathrm{m}), 4.39-4.48(3 \mathrm{H}, \mathrm{m}), 4.30-4.34$ $(3 \mathrm{H}, \mathrm{m}), 4.21(1 \mathrm{H}, \mathrm{d}, J=12 \mathrm{~Hz}), 4.06(1 \mathrm{H}, \mathrm{d}, J=2.4 \mathrm{~Hz}), 3.95(3 \mathrm{H}, \mathrm{t}, J=9.3 \mathrm{~Hz}), 3.60-3.66(5 \mathrm{H}, \mathrm{m})$, $3.24(2 \mathrm{H}, \mathrm{s}), 2.40(3 \mathrm{H}, \mathrm{s}), 2.39(9 \mathrm{H}, \mathrm{s}), 2.36(3 \mathrm{H}, \mathrm{s}), 2.34(3 \mathrm{H}, \mathrm{s}), 2.31(3 \mathrm{H}, \mathrm{s}), 2.27(3 \mathrm{H}, \mathrm{s})$.

${ }^{13} \mathrm{C}$ NMR (100 MHz, $\left.\mathrm{CDCl}_{3}\right): \delta=137.57,137.26,137.11,137.07,136.98,136.83,136.81,136.09,135.90$, $135.20,135.03,134.88,134.15,131.16,130.10,129.64,129.14,129.12,129.07,129.03,128.99,128.98$, $128.93,128.84,128.76,128.70,128.51,128.20,128.17,128.10,127.90,127.87,96.18,87.57,82.75$, 
$81.95,79.59,75.48,74.66,74.30,73.52,73.40,73.18,72.99,72.48,72.14,71.70,69.99,68.66,67.70$, $21.25,21.23,21.18,21.15,21.10$.

HRMS (ESI+) for $\mathrm{C}_{75} \mathrm{H}_{84} \mathrm{NaO}_{10} \mathrm{~S}(+)[\mathrm{M}+\mathrm{Na}:]^{+}$calcd 1199.5683; found 1199.5687.

\section{Synthesis of Mbn protected $\alpha$-D-glucopyranosyl-(1-2)- $\beta$-galactopyranosyl $(2 S, 5 R)$-hydroxylysine building block 11}

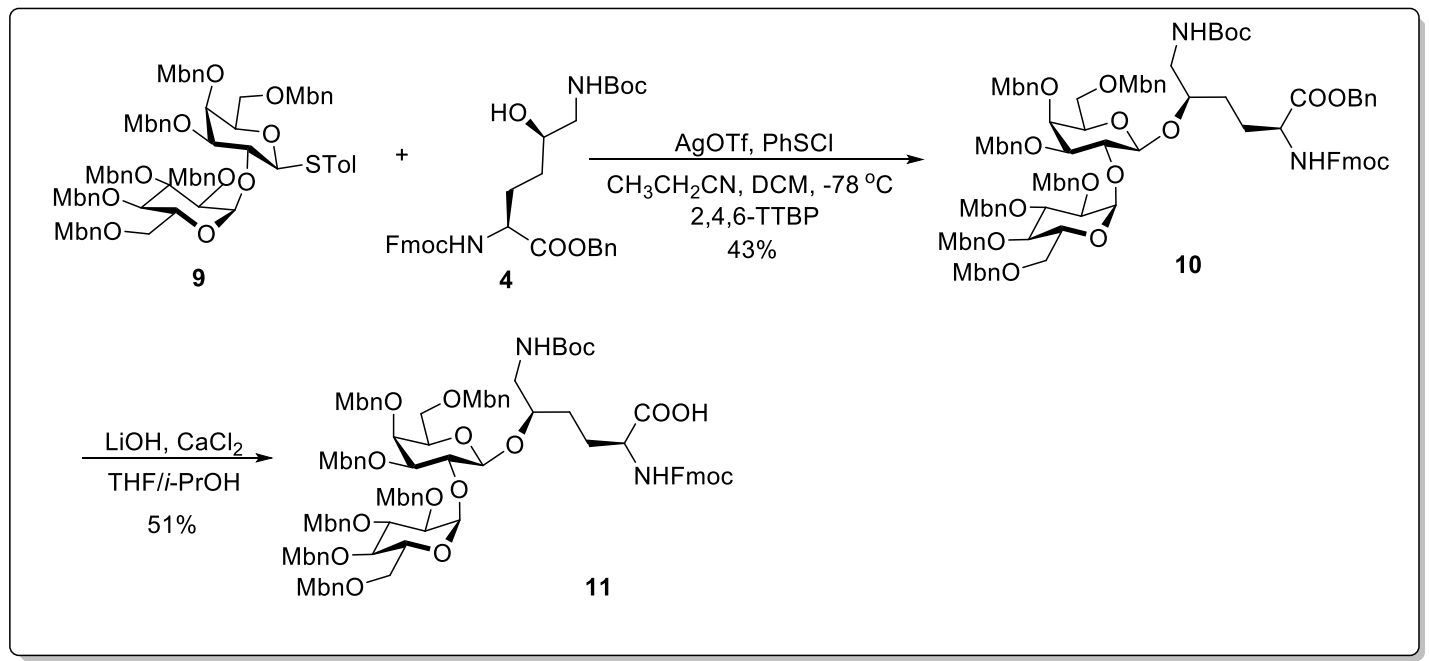

Scheme S7. Synthesis of glycosylated (2S,5R)-hydroxylysine building block 11

\section{Compound 10:}

The suspension of compound 9 (624 mg, $0.53 \mathrm{mmol}, 1.0$ equiv.), compound 4 (609 mg, $1.06 \mathrm{mmol}, 2.0$ equiv.), AgOTf (136 mg, $0.53 \mathrm{mmol}, 1.0$ equiv.), 2,4,6-tri-tert-butylpyrimidine (131 mg, $0.53 \mathrm{mmol}, 1.0$ equiv.) and flame-dried $4 \AA$ molecular sieves $(2.00 \mathrm{~g})$ in anhydrous propionitrile $(18 \mathrm{~mL})$ and anhydrous DCM $(6 \mathrm{~mL})$ was stirred for $30 \mathrm{~min}$ under argon. The mixture was then cooled to $-78{ }^{\circ} \mathrm{C}$, and benzenesulfenyl chloride ( $71 \mu \mathrm{L}, 1.25 \mathrm{mmol}, 2.4$ equiv.) was added slowly in $15 \mathrm{~min}$. The reaction mixture was stirred for $1.5 \mathrm{~h}$ at $-78{ }^{\circ} \mathrm{C}$ and quenched by $\mathrm{Et}_{3} \mathrm{~N}$ after full conversion of compound 9 . The suspension was filtered through celite, and the filtering cake was thoroughly washed with EtOAc (150 
$\mathrm{mL})$. The filtrate was washed with saturated $\mathrm{NaHCO}_{3}(2 \times 30 \mathrm{~mL})$ and brine $(30 \mathrm{~mL})$. The organic phase was dried over anhydrous $\mathrm{Na}_{2} \mathrm{SO}_{4}$ and concentrated under vacuum. The residue was purified by silica gel chromatography ( $n$-hexane/EtOAc $=3: 1)$ to give compound 10 as a white solid $(371 \mathrm{mg}, 43 \%)$. The excess amount of compound 4 was recovered.

${ }^{1} \mathrm{H}$ NMR (400 MHz, $\left.\mathrm{CDCl}_{3}\right): \delta=7.78(2 \mathrm{H}, \mathrm{d}, J=8.0 \mathrm{~Hz}), 7.62(\mathrm{~m}, \mathrm{dd}, J=8.0 \mathrm{~Hz}), 7.41(2 \mathrm{H}, \mathrm{t}, J=8)$, 7.31-7.35 (7H, m), 7.06-7.23 (24H, m), $6.99(2 \mathrm{H}, \mathrm{d}, J=7.6 \mathrm{~Hz}), 6.84(2 \mathrm{H}, \mathrm{d}, J=8.6 \mathrm{~Hz}), 5.62(1 \mathrm{H}, \mathrm{s})$, $5.54(1 \mathrm{H}, \mathrm{t}, J=6.3 \mathrm{~Hz}), 5.14(2 \mathrm{H}, \mathrm{s}), 4.88(1 \mathrm{H}, \mathrm{d}, J=10.6), 4.72-4.83(4 \mathrm{H}, \mathrm{m}), 4.49-4.62(6 \mathrm{H}, \mathrm{m})$, 4.16-4.40 (9H, m), $4.00(1 \mathrm{H}, \mathrm{t}, J=9.6 \mathrm{~Hz}), 3.88(1 \mathrm{H}, \mathrm{s}), 3.44-3.71(9 \mathrm{H}, \mathrm{m}), 3.24-3.29(2 \mathrm{H}, \mathrm{m})$, 2.33-2.39 (21H, m), 1.65-1.79 (4H, m), $1.44(9 \mathrm{H}, \mathrm{s})$.

${ }^{13} \mathrm{C} \mathrm{NMR}\left(100 \mathrm{MHz}, \mathrm{CDCl}_{3}\right): \delta=172.13,156.88,156.24,144.05,143.95,141.23,137.62,137.33,137.29$, $137.25,137.13,137.05,136.85,135.99,135.90,135.50,135.15,135.10,134.68,134.36,129.17,129.10$, $129.08,128.97,128.89,128.80,128.56,128.55,128.37,128.30,128.20,128.16,128.11,128.00,127.75$, $127.63,127.18,127.13,125.39,125.31,119.88,102.67,95.64,82.07,81.33,79.40,79.12,78.80,77.89$, $75.36,74.78,74.28,73.48,73.16,73.01,72.87,72.59,72.19,69.77,68.98,67.89,67.17,67.02,54.03$, $47.07,42.79,29.74,28.74,28.08,27.60,21.22,21.20,21.18,21.15,21.11$.

HRMS (ESI+) for $\mathrm{C}_{94} \mathrm{H}_{108} \mathrm{~N}_{2} \mathrm{O}_{17}(+)[\mathrm{M}+\mathrm{H}]^{+}$: calcd 1628.8229; found 1628.8259

\section{Compound 11:}

To the solution of compound $\mathbf{1 0}$ (371 $\mathrm{mg}, 0.228 \mathrm{mmol}, 1.0$ equiv.) in isopropanol (12.5 mL) and THF (3 $\mathrm{mL})$, was added powdered $\mathrm{CaCl}_{2}\left(1.40 \mathrm{~g}, 12.5 \mathrm{mmol}, 54.8\right.$ equiv.). To this mixture, $\mathrm{LiOH} \cdot \mathrm{H}_{2} \mathrm{O}(140 \mathrm{mg}$, $3.3 \mathrm{mmol}, 14.5$ equiv. $)$ dissovled in water $(3.5 \mathrm{~mL})$ was added. The mixture was vigorously stirred at room temperature overnight. The $\mathrm{pH}$ was then adjusted to 2 with $1 \% \mathrm{HCl}$ and the organic solvents were removed under vacuum. The aqueous layer was extracted with ethyl acetate $(150 \mathrm{~mL})$ and the organic layer was washed with water and brine. The organic phase was dried over anhydrous $\mathrm{Na}_{2} \mathrm{SO}_{4}$ and concentrated under vacuum. The product was purified by flash chromatography $(n$-hexane/EtOAc $=1: 1$ 
with $0.1 \%$ acetic acid) to yield compound $11(179 \mathrm{mg}, 51 \%)$ as a white solid, and the unreacted compound 10 was recovered.

${ }^{1} \mathrm{H}$ NMR $\left(400 \mathrm{MHz}, \mathrm{CDCl}_{3}\right): \delta=7.75(2 \mathrm{H}, \mathrm{d}, J=8.0 \mathrm{~Hz}), 7.60-7.61(2 \mathrm{H}, \mathrm{m}), 7.38-7.41(2 \mathrm{H}, \mathrm{m})$, 7.28-7.34 (2H, m), 7.10-7.19 (24H, m), $7.00(2 \mathrm{H}, \mathrm{d}, J=4.0 \mathrm{~Hz}), 6.85(2 \mathrm{H}, \mathrm{d}, J=8.0 \mathrm{~Hz}), 5.77-5.84(2 \mathrm{H}$, m), $5.63(1 \mathrm{H}, \mathrm{s}), 4.71-4.96(6 \mathrm{H}, \mathrm{m}), 4.46-4.64(6 \mathrm{H}, \mathrm{m}), 4.27-4.39(5 \mathrm{H}, \mathrm{m}), 4.13-4.23(3 \mathrm{H}, \mathrm{m})$, 3.99-4.03 (1H, m), 3.75-3.85 (1H, m), 3.40-3.72 (9H, m), 3.21-3.30 (1H, m), 2.25-2.39 (21H, m), $1.60-1.86(4 \mathrm{H}, \mathrm{m}), 1.45(9 \mathrm{H}, \mathrm{s})$.

${ }^{13} \mathrm{C} \mathrm{NMR}\left(101 \mathrm{MHz}, \mathrm{CDCl}_{3}\right): \delta=174.47,156.91,156.31,144.02,143.95,141.23,137.67,137.33,137.27$, 137.03, 136.91, 135.92, 135.90, 135.44, 135.10, 134.92, 134.48, 134.40, 129.18, 129.10, 129.04, 128.98, $128.98,128.91,128.82,128.57,128.45,128.28,128.22,128.07,127.99,127.88,127.65,127.61,127.16$, $127.15,125.37,125.34,119.91,119.86,102.73,95.49,81.99,81.32,79.42,79.23,77.81,77.29,75.34$, $74.84,74.20,73.39,73.36,73.12,73.09,72.56,72.52,72.21,69.72,69.01,67.77,67.08,53.63,47.16$, $47.07,43.45,28.70,28.51,21.24,21.20,21.17,21.16,21.12$.

HRMS (ESI+) for $\mathrm{C}_{101} \mathrm{H}_{115} \mathrm{~N}_{2} \mathrm{O}_{16} \mathrm{~S}(+)[\mathrm{M}+\mathrm{H}]^{+}$: calcd 1538.7760; found 1538.7781. 


\section{Synthesis of protected salicylaldehyde}

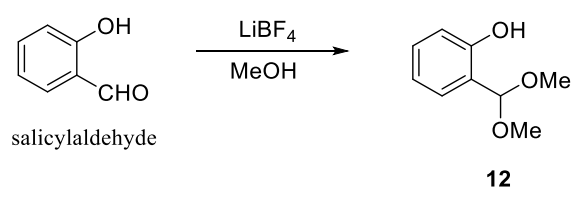

Scheme S8. Synthesis of $\alpha, \alpha$-dimethoxy-salicylaldehyde

\section{Compound 12:}

To a solution of salicylaldehyde $(2.44 \mathrm{~g}, 20 \mathrm{mmol})$ and $\mathrm{LiBF}_{4}(56 \mathrm{mg}, 0.6 \mathrm{mmol})$ in anhydrous $\mathrm{CH}_{3} \mathrm{OH}$ $(10 \mathrm{~mL})$, trimethyl orthoformate $(2.76 \mathrm{~g}, 20 \mathrm{mmol})$ was added. The mixture was stirred overnight under reflux condition, then it was quenched by saturated $\mathrm{NaHCO}_{3}(40 \mathrm{~mL})$. The mixture was diluted with EtOAc $(150 \mathrm{~mL})$ and washed with saturated $\mathrm{NaHCO}_{3}(2 \times 30 \mathrm{~mL})$ and brine $(30 \mathrm{~mL})$. The organic phase was dried over anhydrous $\mathrm{Na}_{2} \mathrm{SO}_{4}$ and concentrated under vacuum. The resulting residue was directly used without further purification.

\section{Reference:}

1.Chen, J.; Wang, P.; Zhu, J.; Wan, Q.; Danishefsky, S. J. A program for ligation at threonine sites: application to the controlled total synthesis of glycopeptides. Tetrahedron. 2010, 66, 2277-2283. 


\section{Synthesis of Adiponectin collagenous domain}

\section{1 synthesis of peptide WM}

\subsection{Preparation of peptide SAL ester WM-a}

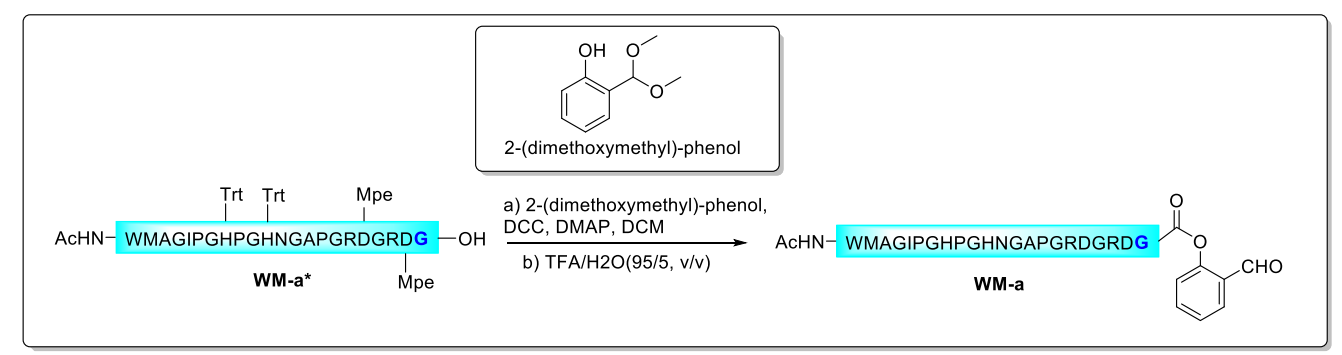

Crude fully protected peptide WM-a* bearing C-terminal free carboxylic acid and N-terminal Ac was synthesized via Fmoc-SPPS according to the general procedures A and B using 2-chlorotrityl chloride resin. The fully protected peptidic acid $(198.1 \mathrm{mg}, 50 \mu \mathrm{mol})$ was coupled with 2-(dimethoxymethyl)phenol $12(182.7 \mathrm{mg}, 1087.5 \mu \mathrm{mol})$ in anhydrous $\mathrm{CH}_{2} \mathrm{Cl}_{2}$ overnight, in the presence of $N, N^{\prime}$ dicyclohexylcarbodiimide (DCC) $(56.1 \mathrm{mg}, 271.9 \mu \mathrm{mol})$ and 4-dimethylaminopyridine (DMAP) $(3.3 \mathrm{mg}$, 2.7 $\mu \mathrm{mol}$ ). Upon completion, the reaction mixture was concentrated and subjected to the treatment with TFA $/ \mathrm{H}_{2} \mathrm{O}(95 / 5, \mathrm{v} / \mathrm{v})$ for $1.5 \mathrm{~h}$. The crude peptide SAL ester was precipitated out by cold diethyl ether. After decanting diethyl ether, the remaining solid was dissolved in $10 \mathrm{~mL} 15 \% \mathrm{CH}_{3} \mathrm{CN} / \mathrm{H}_{2} \mathrm{O}$ and subjected to preparative HPLC purification $\left(10-50 \% \mathrm{CH}_{3} \mathrm{CN} / \mathrm{H}_{2} \mathrm{O}\right.$ over $\left.30 \mathrm{~min}\right)$. Then lyophilization afforded WM-a (19.7 mg, 17\% yield) as a white powder. 

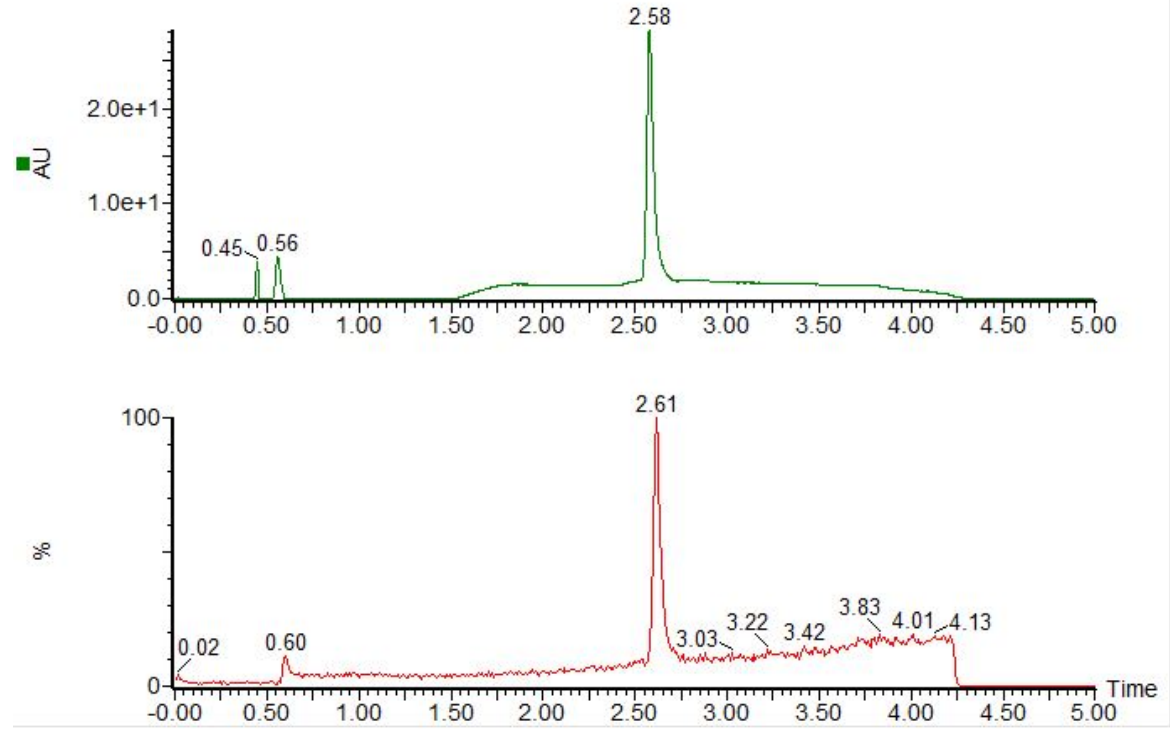

Figure 1. UV (190-400 nm) and MS (250-3000 m/z) traces from UPLC-MS analysis of purified WM-a (gradient 5-95\% $\mathrm{CH}_{3} \mathrm{CN} / \mathrm{H}_{2} \mathrm{O}$ containing $0.1 \%$ TFA over $5 \mathrm{~min}$ at a flow rate of $0.4 \mathrm{~mL} / \mathrm{min}$ ).

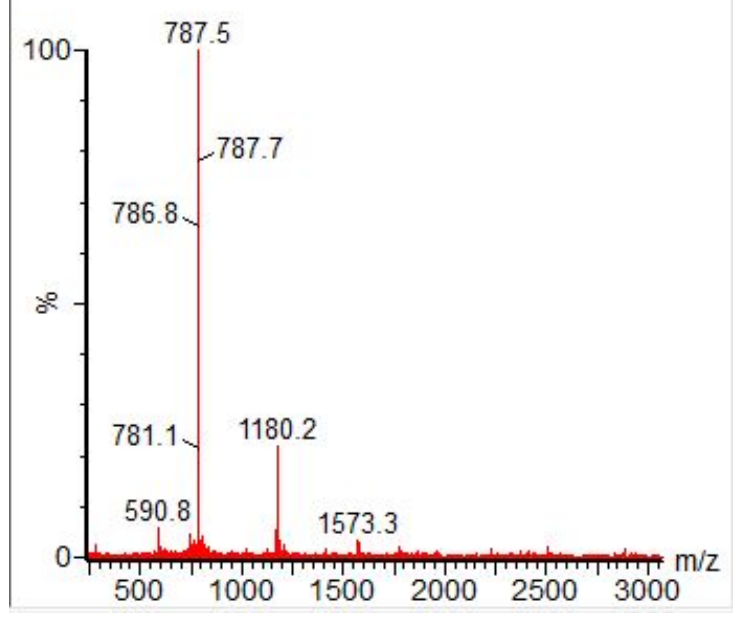

Figure 2. ESI-MS calcd. for $\mathrm{C}_{102} \mathrm{H}_{144} \mathrm{~N}_{34} \mathrm{O}_{30} \mathrm{~S}$, $[\mathrm{M}+2 \mathrm{H}]^{2+} \mathrm{m} / z=1180.2$, found $1180.2 ;[\mathrm{M}+3 \mathrm{H}]^{3+} \mathrm{m} / z=$ 787.2, found 787.5; $[\mathrm{M}+4 \mathrm{H}]^{4+} m / z=590.6$, found 591.8 . 


\subsection{Preparation of peptide WM-b}

$$
\text { H-TPGEKGEKGDPGLIGPKGDIGETGVPGAEGPRGFPGIQGRKGEPGEG-OH }
$$

WM-b

Peptide WM-b was synthesized according to the general procedure A using 2-chlorotrityl chloride resin (50 mg). Upon completion of synthesis, the peptide resin was subjected to the cleavage using $5 \mathrm{~mL}$ TFA $/ \mathrm{H}_{2} \mathrm{O} / \mathrm{TIPS}(95 / 2.5 / 2.5, \mathrm{v} / \mathrm{v} / \mathrm{v})$ for $1 \mathrm{~h}$. The resin was filtered and the combined filtrate was blown off under a stream of condensed $\mathrm{N}_{2}$. The crude product was treated with cold $\left(-20{ }^{\circ} \mathrm{C}\right)$ diethyl ether $(45 \mathrm{~mL})$, and the resulting suspension was centrifuged to give a white pellet. After decanting diethyl ether, the remaining solid was dissolved in $10 \mathrm{~mL} 50 \% \mathrm{CH}_{3} \mathrm{CN} / \mathrm{H}_{2} \mathrm{O}$ and subjected to preparative HPLC purification $\left(20-50 \% \mathrm{CH}_{3} \mathrm{CN} / \mathrm{H}_{2} \mathrm{O}\right.$ over $\left.45 \mathrm{~min}\right)$. Then lyophilization afforded $\mathbf{W M}-\mathbf{b}(31.0 \mathrm{mg}, 26 \%)$ as a white powder.
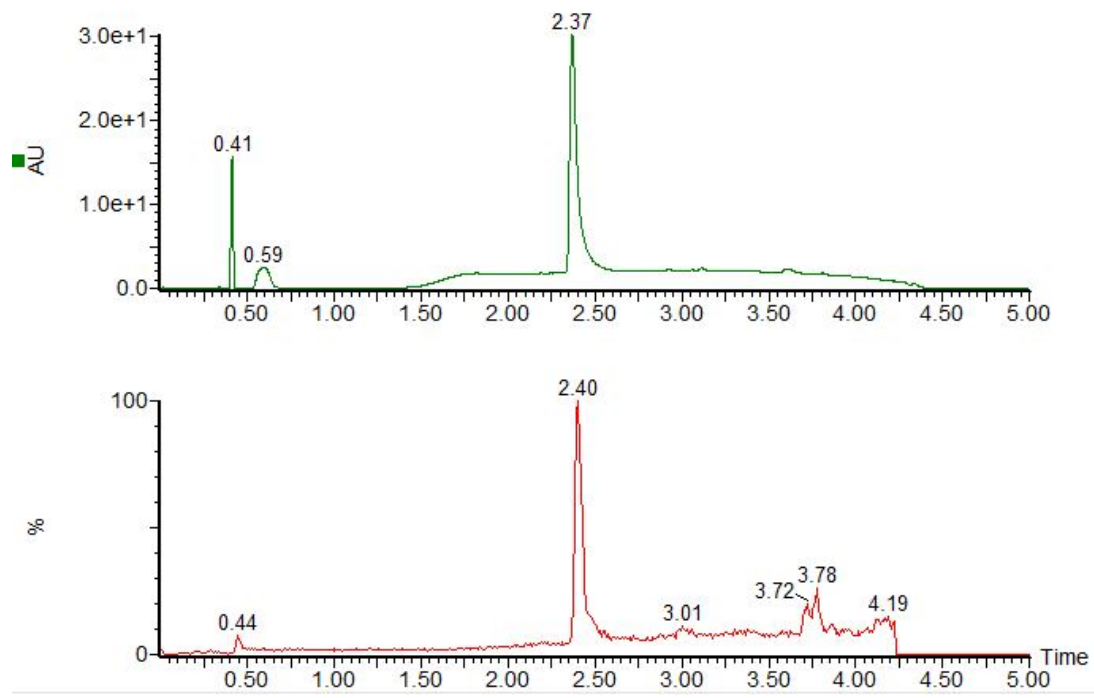

Figure 3. UV (190-400 nm) and MS (250-3000 m/z) traces from UPLC-MS analysis of WM-b (gradient $5-95 \% \mathrm{CH}_{3} \mathrm{CN} / \mathrm{H}_{2} \mathrm{O}$ containing $0.1 \%$ TFA over $5 \mathrm{~min}$ at a flow rate of $0.4 \mathrm{~mL} / \mathrm{min}$ ). 


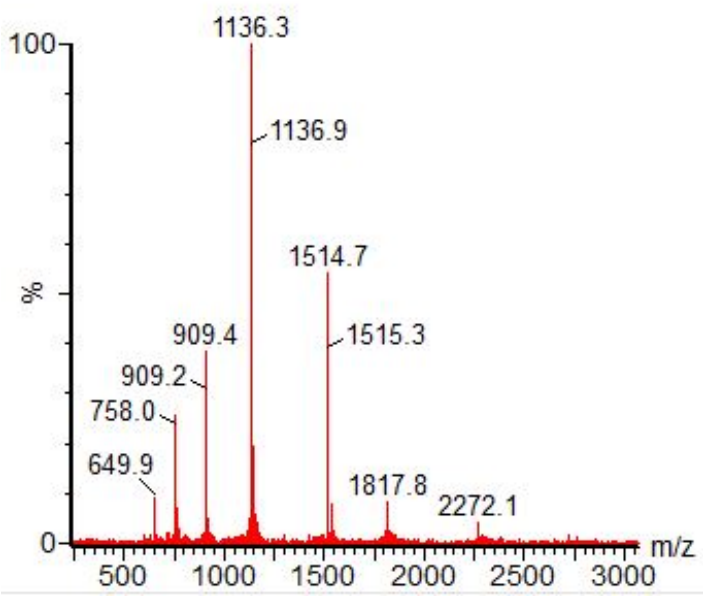

Figure 4. ESI-MS calcd. for $\mathrm{C}_{195} \mathrm{H}_{312} \mathrm{~N}_{58} \mathrm{O}_{67},[\mathrm{M}+2 \mathrm{H}]^{2+} \mathrm{m} / z=2271.5$, found $2272.1 ;[2 \mathrm{M}+5 \mathrm{H}]^{5+} m / z=$ 1817.4, found 1817.8; $[\mathrm{M}+3 \mathrm{H}]^{3+} \mathrm{m} / z=1514.7$, found 1514.7; $[\mathrm{M}+4 \mathrm{H}]^{4+} \mathrm{m} / z=1136.2$, found 1136.3; $[\mathrm{M}+5 \mathrm{H}]^{5+} \mathrm{m} / \mathrm{z}=909.2$, found 909.2; $[\mathrm{M}+6 \mathrm{H}]^{6+} \mathrm{m} / \mathrm{z}=757.8$, found 758.0; $[\mathrm{M}+7 \mathrm{H}]^{7+} \mathrm{m} / \mathrm{z}=649.7$, found 649.9.

\subsection{Preparation of peptide WM by STL}

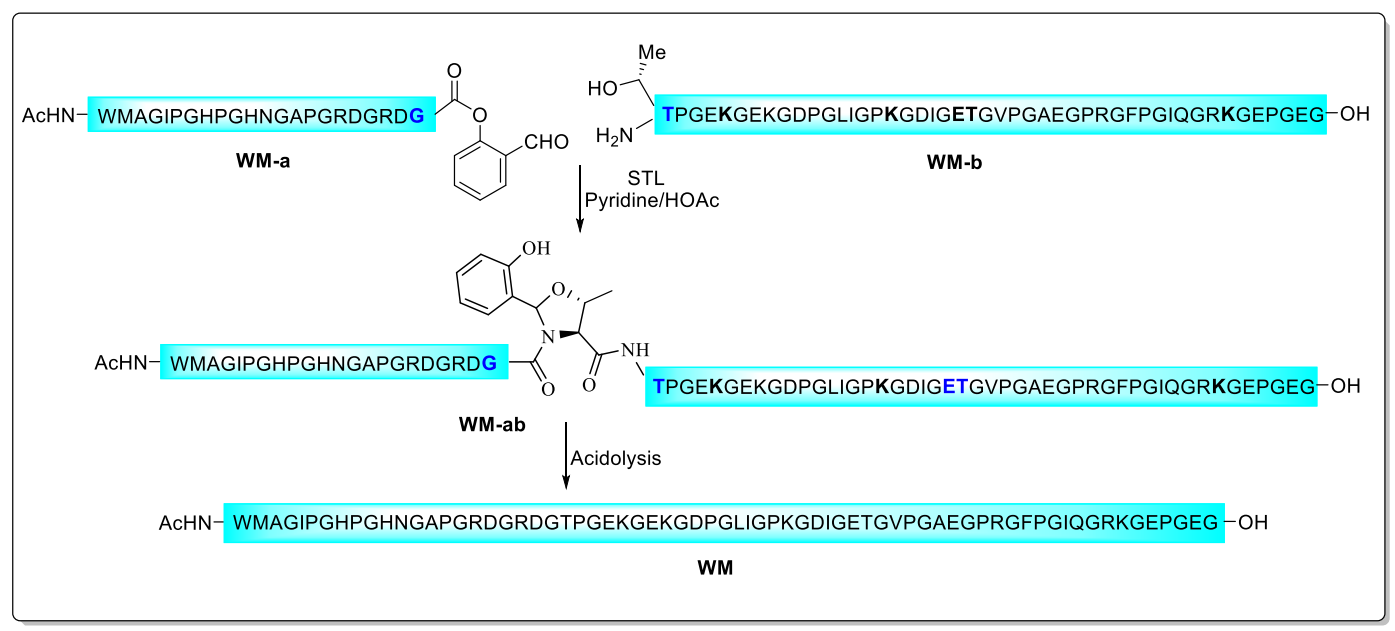

WM-b $(5.9 \mathrm{mg}, 1.2 \mu \mathrm{mol})$ and WM-a $(2.8 \mathrm{mg}, 1.2 \mu \mathrm{mol})$ were dissolved in pyridine/acetic acid (1/1, mole/mole) buffer at a concentration of $15 \mathrm{mM}$ at room temperature. The reaction mixture was stirred at room temperature for $4 \mathrm{~h}$ to give ligation intermediate $\mathbf{W} \mathbf{M}^{*}$, and the solvent was then blown off under a 
stream of $\mathrm{N}_{2}$. The residue was treated with $1 \mathrm{~mL} \mathrm{TFA} / \mathrm{H}_{2} \mathrm{O}(95 / 5, \mathrm{v} / \mathrm{v})$ for $30 \mathrm{~min}$ to obtain crude product WM, and the volatile species were then blown off under a stream of condensed $\mathrm{N}_{2}$. After that, the remaining residue was subjected to preparative HPLC purification $\left(10-35 \% \mathrm{CH}_{3} \mathrm{CN} / \mathrm{H}_{2} \mathrm{O}\right.$ over 30 min). Then lyophilization afforded WM (3.0 mg, 37\%) as a white powder.
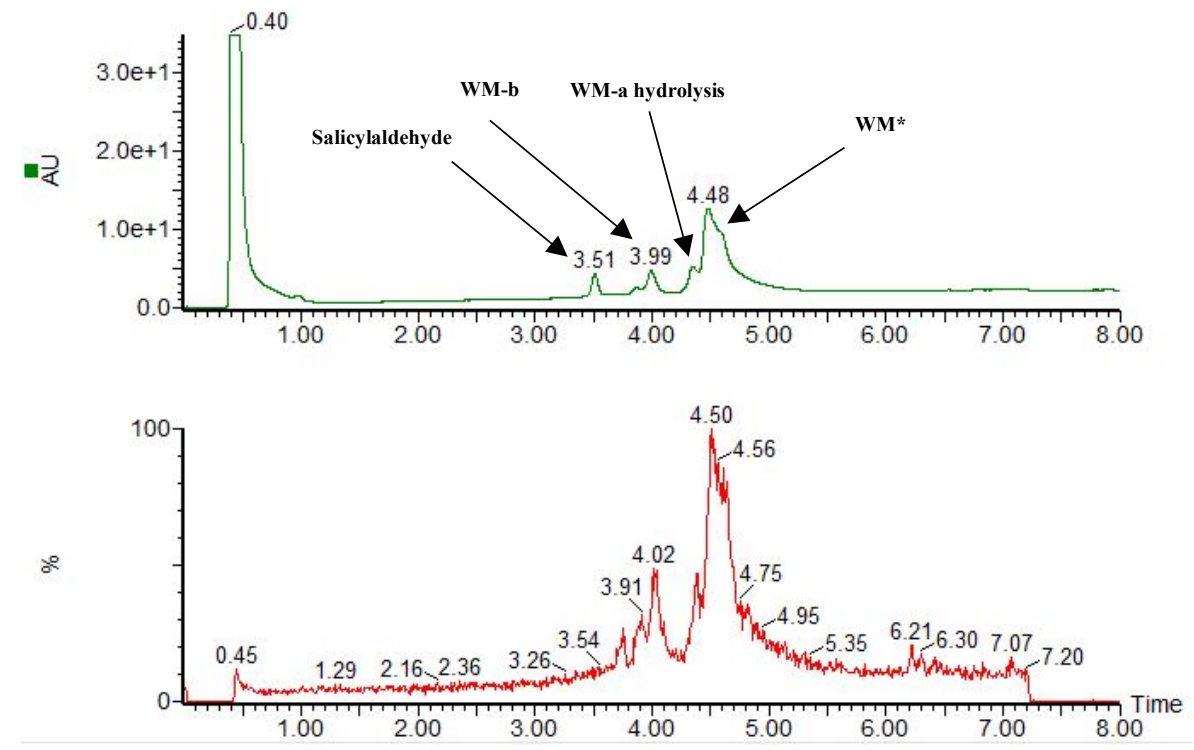

Figure 5. UV (190-400 $\mathrm{nm})$ and MS (250-3000 m/z) traces from UPLC-MS analysis of STL between WM-b and WM-a at $4 \mathrm{~h}$ (gradient $10-40 \% \mathrm{CH}_{3} \mathrm{CN} / \mathrm{H}_{2} \mathrm{O}$ containing $0.1 \%$ TFA over 8 min at a flow rate of $0.4 \mathrm{~mL} / \mathrm{min})$. 

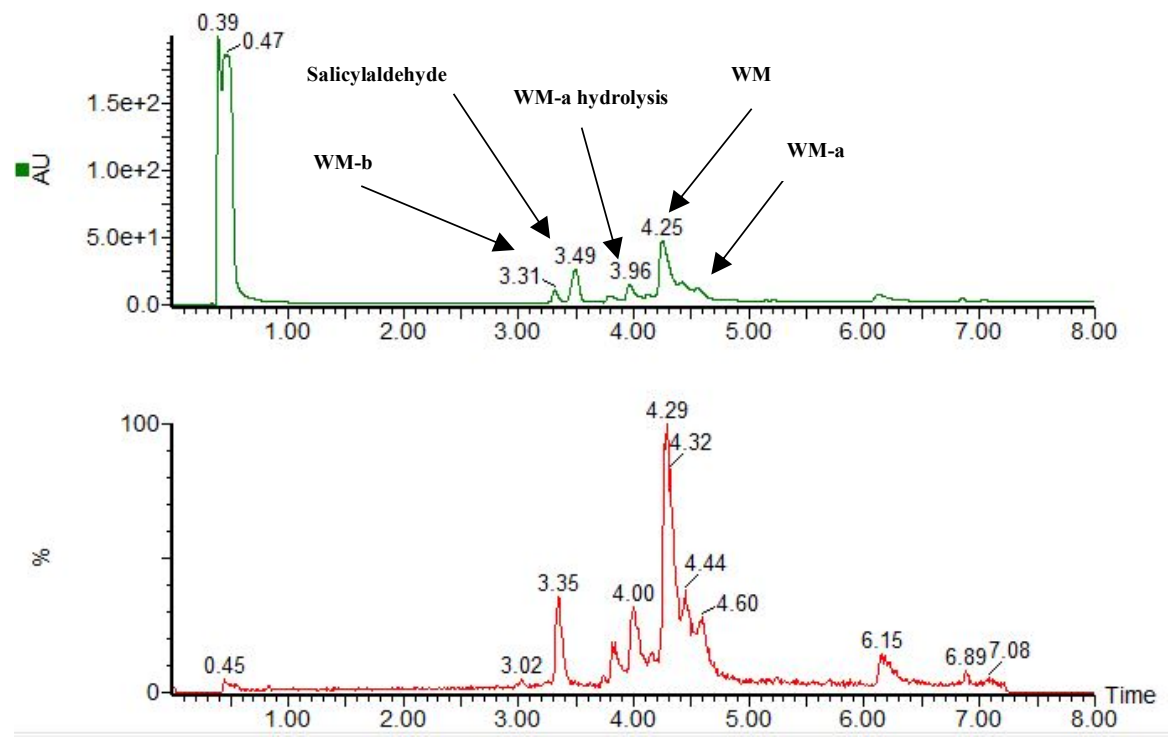

Figure 6. UV (190-400 nm) and MS (250-3000 m/z) traces from UPLC-MS analysis of acidolysis of STL between WM-b and WM-a at $4 \mathrm{~h}$ (gradient $10-35 \% \mathrm{CH}_{3} \mathrm{CN} / \mathrm{H}_{2} \mathrm{O}$ containing $0.1 \%$ TFA over 8 min at a flow rate of $0.4 \mathrm{~mL} / \mathrm{min})$.

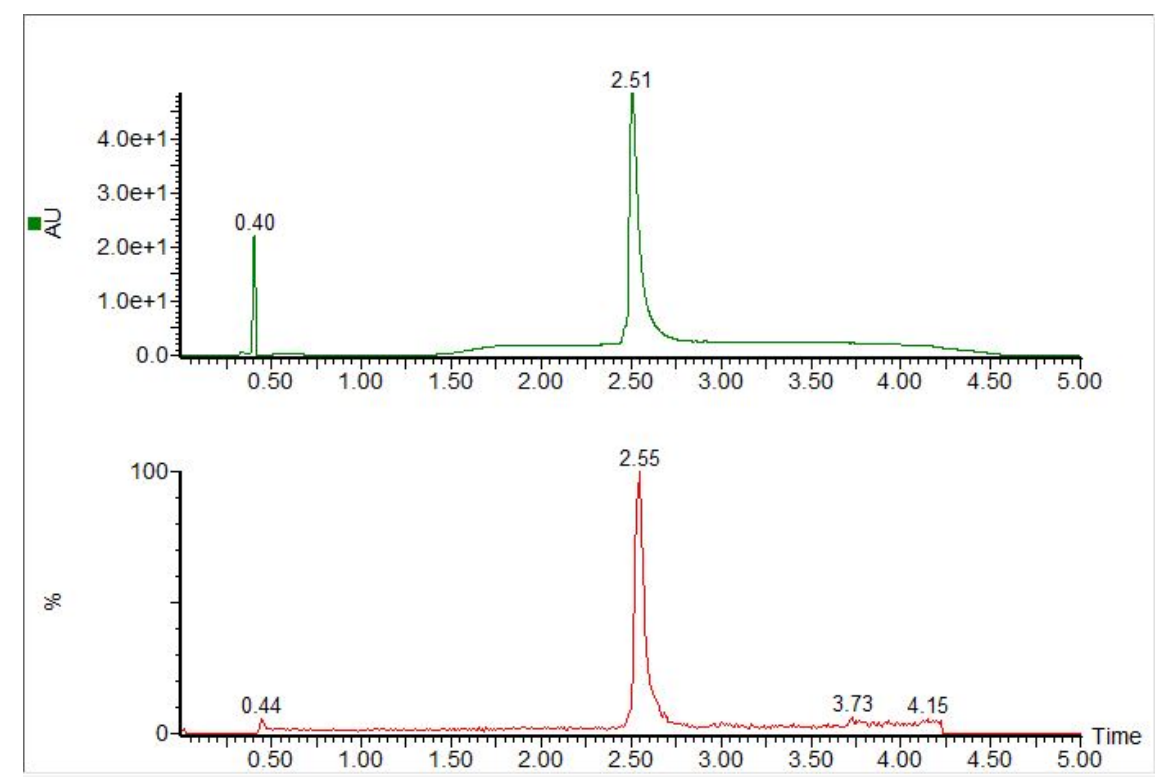

Figure 7. UV (190-400 $\mathrm{nm})$ and MS (250-3000 m/z) traces from UPLC-MS analysis of purified WM (gradient 5-95\% $\mathrm{CH}_{3} \mathrm{CN} / \mathrm{H}_{2} \mathrm{O}$ containing $0.1 \%$ TFA over $5 \mathrm{~min}$ at a flow rate of $0.4 \mathrm{~mL} / \mathrm{min}$ ). 


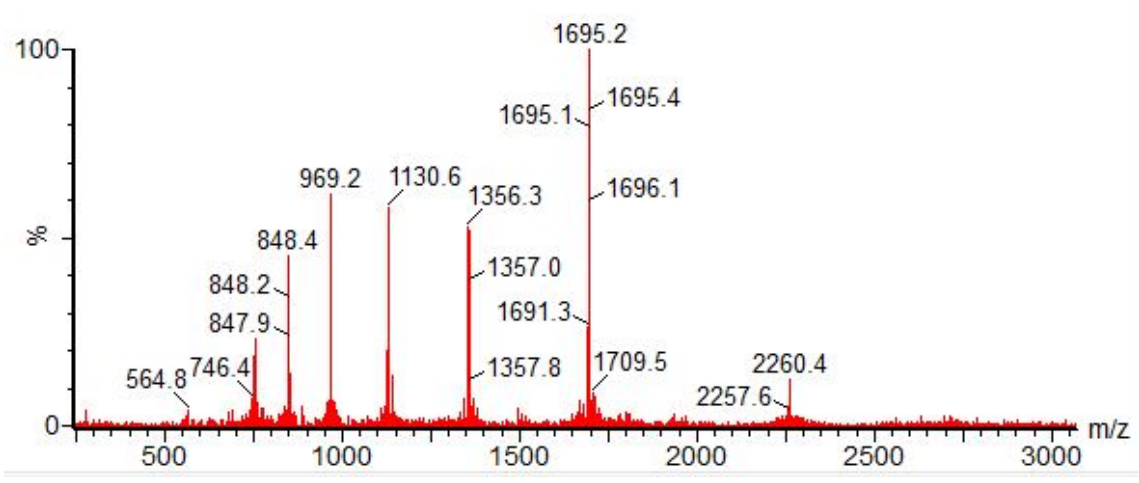

Figure 8. ESI-MS calcd. for $\mathrm{C}_{290} \mathrm{H}_{450} \mathrm{~N}_{92} \mathrm{O} 95 \mathrm{~S},[\mathrm{M}+3 \mathrm{H}]^{3+} \mathrm{m} / \mathrm{z}=2260.13$, found $2260.4 ;[\mathrm{M}+4 \mathrm{H}]^{4+} \mathrm{m} / \mathrm{z}$ $=1695.3$, found 1695.2; $[\mathrm{M}+5 \mathrm{H}]^{5+} \mathrm{m} / z=1356.5$, found 1356.3; $[\mathrm{M}+6 \mathrm{H}]^{6+} \mathrm{m} / z=1130.6$, found 1130.6; $[\mathrm{M}+7 \mathrm{H}]^{7+} m / z=969.2$, found $969.2 ;[\mathrm{M}+8 \mathrm{H}]^{8+} m / z=848.2$, found 848.4 .

\section{Synthesis of peptide WM-65}

\subsection{Preparation of WM65b}

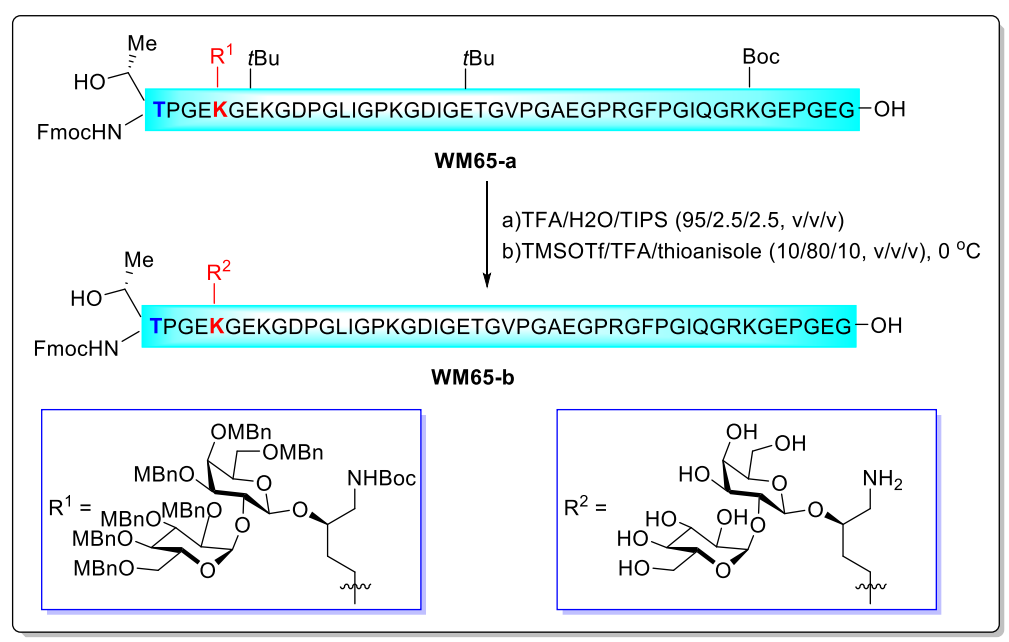


Peptide WM65-a was synthesized according to the general procedure A using 2-chlorotrityl chloride resin $(50 \mathrm{mg})$ by introducing the glycosylated 5-hydroxylysine building-block at desired position. Upon completion of synthesis, the crude peptide was then deprotected and cleaved from the resin using $5 \mathrm{~mL}$ TFA/TIPS/ $\mathrm{H}_{2} \mathrm{O}(90: 5: 5, \mathrm{v} / \mathrm{v} / \mathrm{v})$ for $1 \mathrm{~h}$. The resin was filtered and the combined filtrate was stirred at -10 ${ }^{\circ} \mathrm{C}$ in cooling bath for $10 \mathrm{~min}$. Then, thioanisole $625 \mu \mathrm{L}$ was added to the above solution and stirred for an additional $10 \mathrm{~min}$. TMSOTf $625 \mu \mathrm{L}$ was slowly added to the above solution and stirred at $-10{ }^{\circ} \mathrm{C}$ for 45 min. The reaction solution was poured into cold $\left(-20{ }^{\circ} \mathrm{C}\right)$ diethyl ether $(45 \mathrm{~mL})$, and the resulting suspension was centrifuged to give a white pellet. After decanting diethyl ether, the remaining solid was dissolved in $2 \mathrm{~mL} 50 \% \mathrm{CH}_{3} \mathrm{CN} / \mathrm{H}_{2} \mathrm{O}$ and $\mathrm{NH}_{4} \mathrm{HCO}_{3}$ solid was added until the solution $\mathrm{pH}$ became 7 . The resulting solution was stirred at room temperature for $1 \mathrm{~h}$ and subjected to preparative HPLC purification (20-50\% $\mathrm{CH}_{3} \mathrm{CN} / \mathrm{H}_{2} \mathrm{O}$ over $45 \mathrm{~min}$ ). Lyophilization afforded WM65-b (13.0 $\left.\mathrm{mg}, 10.2 \%\right)$ as a white powder.

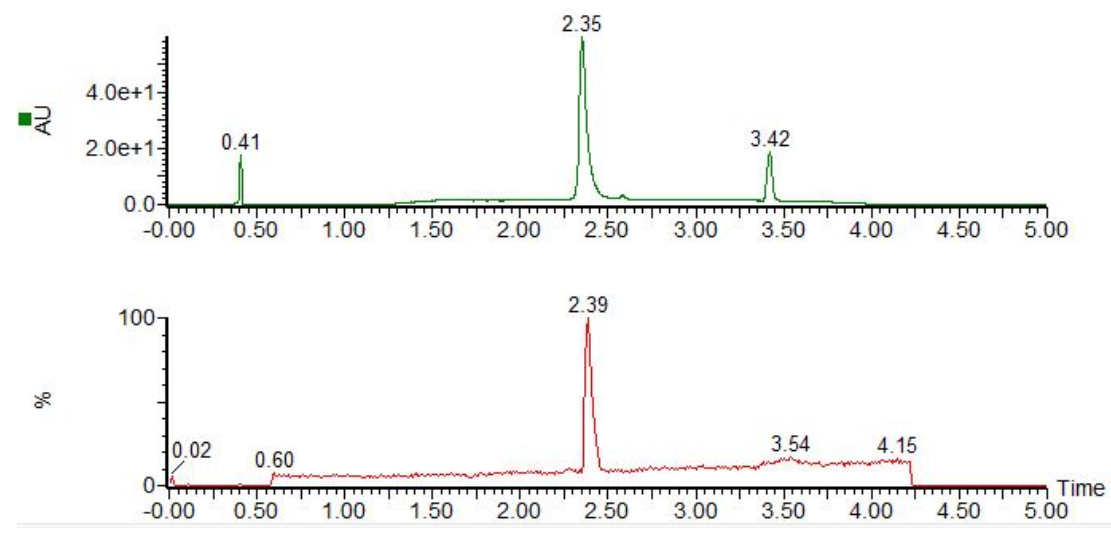

Figure 9. UV (190-400 nm) and MS (250-3000 m/z) traces from UPLC-MS analysis of purified WM65a (gradient $5-95 \% \mathrm{CH}_{3} \mathrm{CN} / \mathrm{H}_{2} \mathrm{O}$ containing $0.1 \%$ TFA over $5 \mathrm{~min}$ at a flow rate of $0.4 \mathrm{~mL} / \mathrm{min}$ ). 


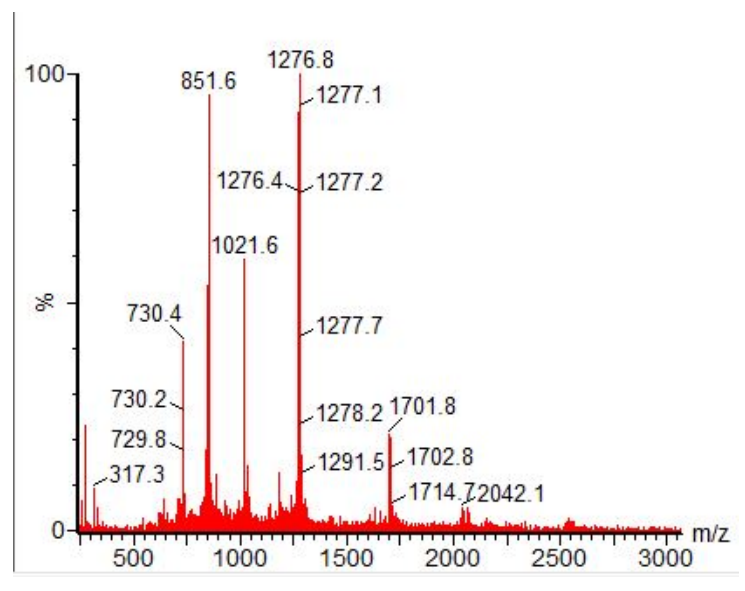

Figure 10. ESI-MS calcd. for $\mathrm{C}_{222} \mathrm{H}_{342} \mathrm{~N}_{58} \mathrm{O}_{80}$, $[\mathrm{M}+3 \mathrm{H}]^{3+} \mathrm{m} / z=1702.2$, found $1701.8 ;[\mathrm{M}+4 \mathrm{H}]^{4+} \mathrm{m} / z=$ 1276.9, found 1276.8; $[\mathrm{M}+5 \mathrm{H}]^{5+} \mathrm{m} / \mathrm{z}=1021.7$, found 1021.6; $[\mathrm{M}+6 \mathrm{H}]^{6+} \mathrm{m} / \mathrm{z}=851.6$, found 851.6; $[\mathrm{M}+7 \mathrm{H}]^{7+} m / z=730.1$, found 730.4 .

\subsection{Preparation of $\mathrm{WM65}$}

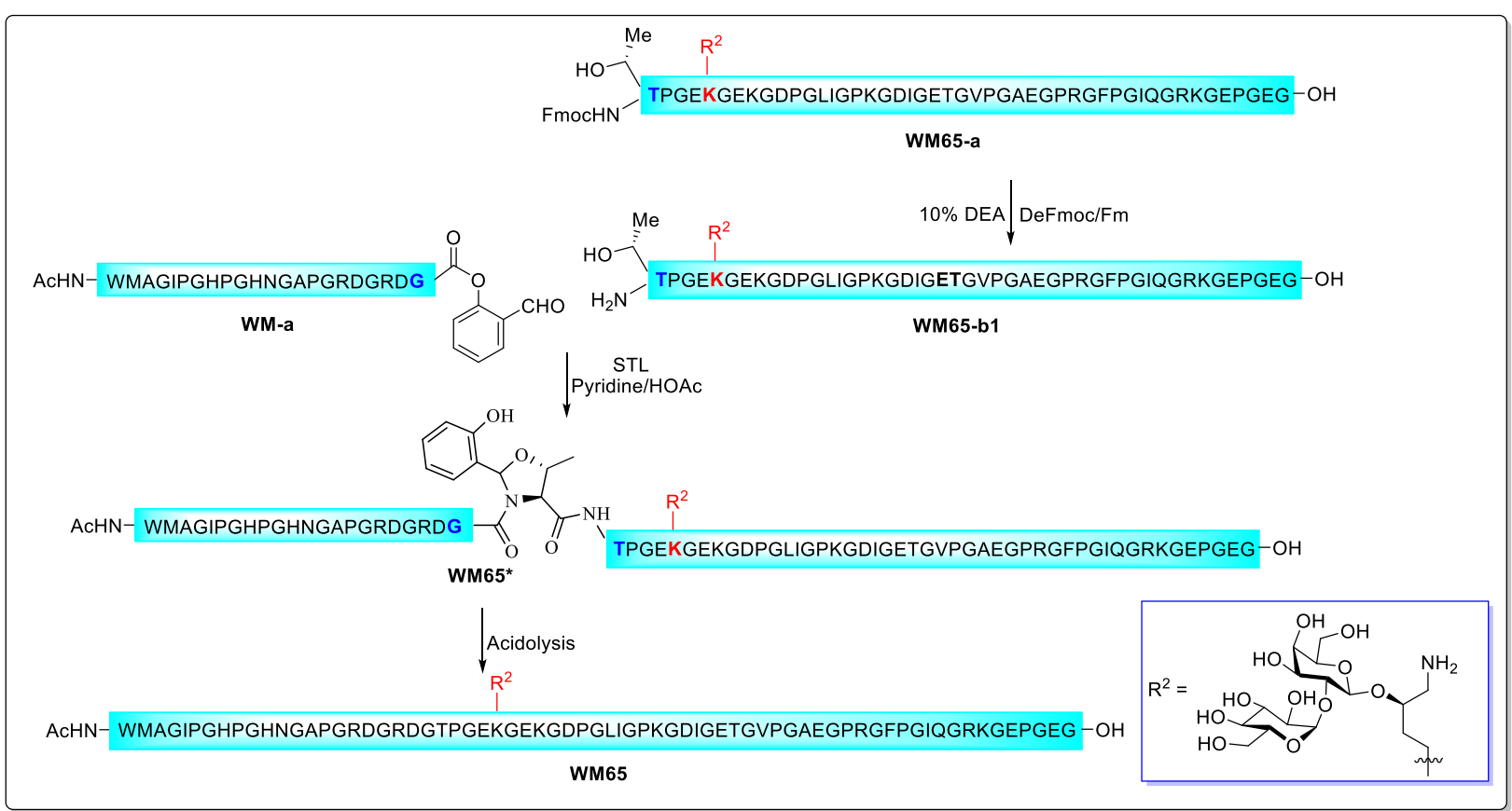


WM65-b (13.0 mg, $2.55 \mu \mathrm{mol})$ was dissolved in $250 \mu \mathrm{L} \mathrm{CH}_{3} \mathrm{CN} / \mathrm{H}_{2} \mathrm{O} /$ diethylamine $(4.5 / 4.5 / 1$, v/v/) at room temperature and stirred at room temperature for $2 \mathrm{~h}$ to give product WM65-b1. The reaction mixture was diluted with $50 \% \mathrm{CH}_{3} \mathrm{CN} / \mathrm{H}_{2} \mathrm{O}(20 \mathrm{~mL})$ and subjected to lyophilization to afford WM65-b1 as a slightly yellow solid. This crude peptide was washed by diethyl ether. After that, the crude WM65b1 and WM-a $(6.0 \mathrm{mg}, 2.55 \mu \mathrm{mol})$ were dissolved in pyridine/acetic acid (1/1, mole/mole) buffer at a concentration of $15 \mathrm{mM}$ at room temperature. The reaction mixture was stirred at room temperature for 4 $\mathrm{h}$ to give ligation intermediate $\mathbf{W M 6 5}{ }^{*}$, and the solvent was then blown off under a stream of condensed $\mathrm{N}_{2}$. The residue was treated with $1 \mathrm{~mL}$ TFA/ $\mathrm{H}_{2} \mathrm{O}(95 / 5, \mathrm{v} / \mathrm{v})$ for $20 \mathrm{~min}$ to obtain crude product WM65, and then TFA was blown off under a stream of condensed $\mathrm{N}_{2}$. The remaining residue was subjected to preparative HPLC purification $\left(10-35 \% \mathrm{CH}_{3} \mathrm{CN} / \mathrm{H}_{2} \mathrm{O}\right.$ over $\left.45 \mathrm{~min}\right)$ and lyophilization to afford WM65 $(6.1 \mathrm{mg}, 34 \%)$ as a white powder.

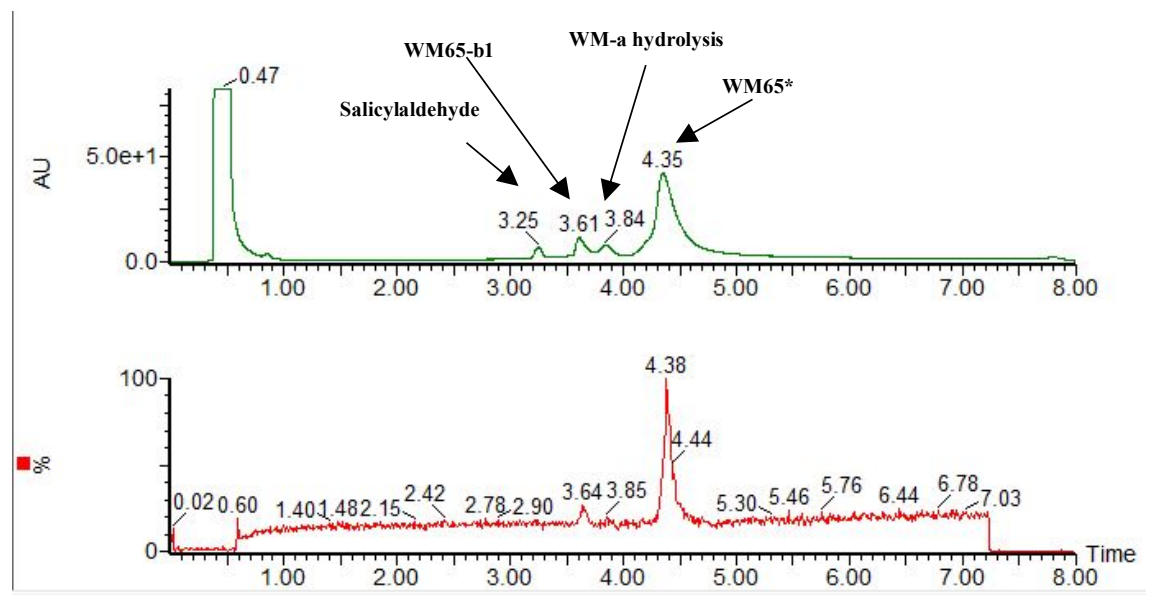

Figure 11. UV (190-400 nm) and MS (250-3000 m/z) traces from UPLC-MS analysis of STL between WM65-b1 and WM-a at $4 \mathrm{~h}$ (gradient $10-40 \% \mathrm{CH}_{3} \mathrm{CN} / \mathrm{H}_{2} \mathrm{O}$ containing $0.1 \%$ TFA over 8 min at a flow rate of $0.4 \mathrm{~mL} / \mathrm{min}$ ). 


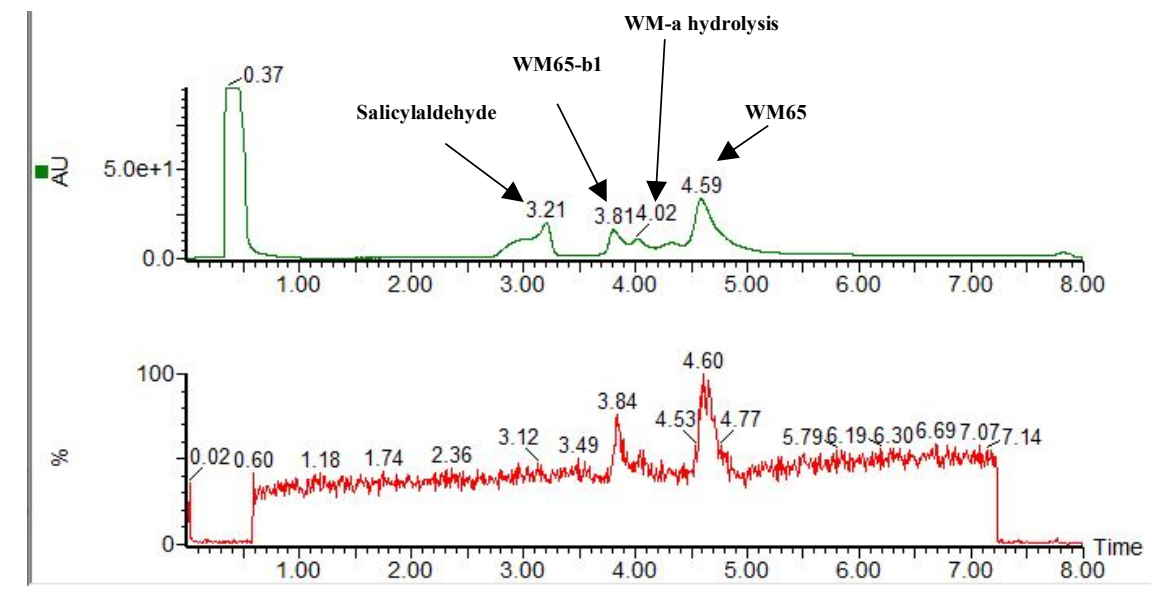

Figure 12. UV (190-400 $\mathrm{nm})$ and MS (250-3000 m/z) traces from UPLC-MS analysis of acidolysis of STL between WM65-b1 and WM-a at $4 \mathrm{~h}$ (gradient 10-35\% $\mathrm{CH}_{3} \mathrm{CN} / \mathrm{H}_{2} \mathrm{O}$ containing $0.1 \%$ TFA over 8 $\min$ at a flow rate of $0.4 \mathrm{~mL} / \mathrm{min}$ ).

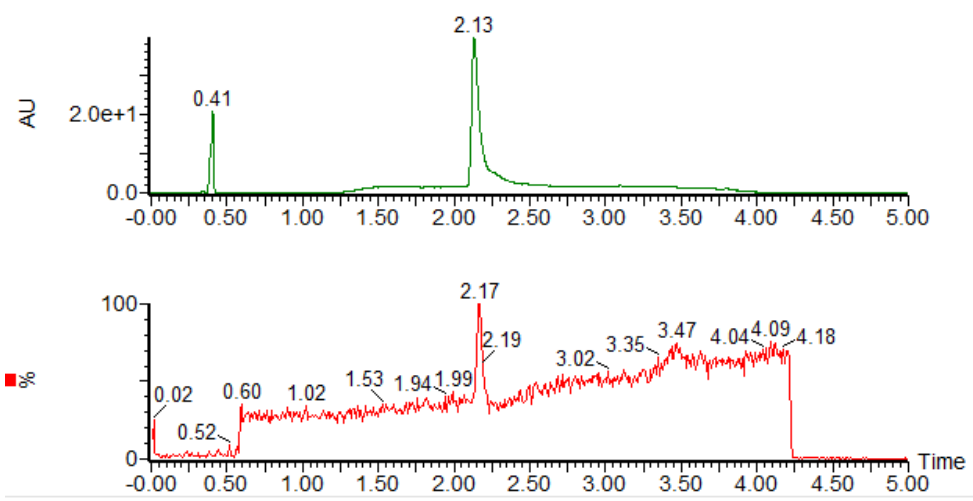

Figure 13. UV (190-400 nm) and MS (250-3000 m/z) traces from UPLC-MS analysis of purified WM65 (gradient 5-95\% $\mathrm{CH}_{3} \mathrm{CN} / \mathrm{H}_{2} \mathrm{O}$ containing $0.1 \%$ TFA over 5 min at a flow rate of $0.4 \mathrm{~mL} / \mathrm{min}$ ). 


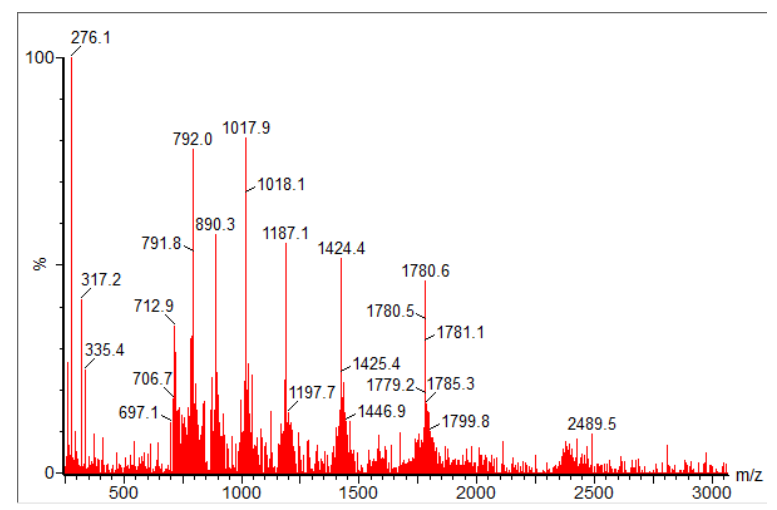

Figure 14. ESI-MS calcd. for $\mathrm{C}_{302} \mathrm{H}_{470} \mathrm{~N}_{92} \mathrm{O}_{106} \mathrm{~S}$, $[\mathrm{M}+4 \mathrm{H}]^{4+} \mathrm{m} / z=1780.4$, found 1780.6 ; $[\mathrm{M}+5 \mathrm{H}]^{5+} \mathrm{m} / z=$ 1424.5, found 1424.4; $[\mathrm{M}+6 \mathrm{H}]^{6+} m / z=1187.3$, found 1187.1; $[\mathrm{M}+7 \mathrm{H}]^{7+} \mathrm{m} / z=1017.8$, found 1017.9; $[\mathrm{M}+8 \mathrm{H}]^{8+} \mathrm{m} / \mathrm{z}=890.7$, found $890.3 ;[\mathrm{M}+9 \mathrm{H}]^{9+} \mathrm{m} / \mathrm{z}=791.9$, found $792.0 ;[\mathrm{M}+10 \mathrm{H}]^{10+} \mathrm{m} / \mathrm{z}=712.8$, found 712.9 .

\section{Synthesis of peptide WM-68}

\subsection{Preparation of WM68b}

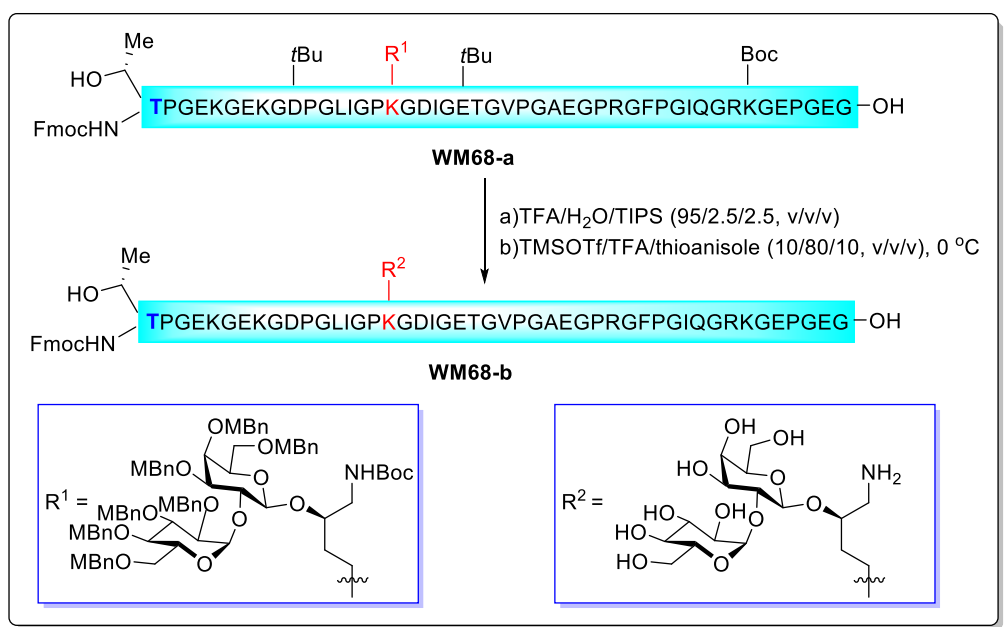

Peptide WM68-a was synthesized according to the general procedure A using 2-chlorotrityl chloride resin $(50 \mathrm{mg})$ by introducing the glycosylated 5-hydroxylysine building-block at specific position. Upon completion of synthesis, the crude peptide was then deprotected and cleaved from the resin using $5 \mathrm{~mL}$ 
TFA/TIPS/ $\mathrm{H}_{2} \mathrm{O}(90: 5: 5, \mathrm{v} / \mathrm{v} / \mathrm{v})$ for $1 \mathrm{~h}$. The resin was filtered and the combined filtrate was stirred at -10 ${ }^{\circ} \mathrm{C}$ in cooling bath for $10 \mathrm{~min}$. Then, thioanisole $625 \mu \mathrm{L}$ was added to the above solution and stirred for an additional $10 \mathrm{~min}$. TMSOTf $625 \mu \mathrm{L}$ was slowly added to the above solution and stirred at $-10{ }^{\circ} \mathrm{C}$ for 45 min. The reaction solution was poured into a cold $\left(-20{ }^{\circ} \mathrm{C}\right)$ diethyl ether $(45 \mathrm{~mL})$, and the resulting suspension was centrifuged to give a white pellet. After decanting diethyl ether, the remaining solid was dissolved in $2 \mathrm{~mL} 50 \% \mathrm{CH}_{3} \mathrm{CN} / \mathrm{H}_{2} \mathrm{O}$ and $\mathrm{NH}_{4} \mathrm{HCO}_{3}$ solid was added until the solution $\mathrm{pH}$ to 7 . The resulting solution was stirred at room temperature for $1 \mathrm{~h}$ and subjected to preparative HPLC purification (20-50\% $\mathrm{CH}_{3} \mathrm{CN} / \mathrm{H}_{2} \mathrm{O}$ over $\left.45 \mathrm{~min}\right)$. Lyophilization afforded WM68-b (11.4 $\mathrm{mg}, 8.9 \%$ ) as a white powder.

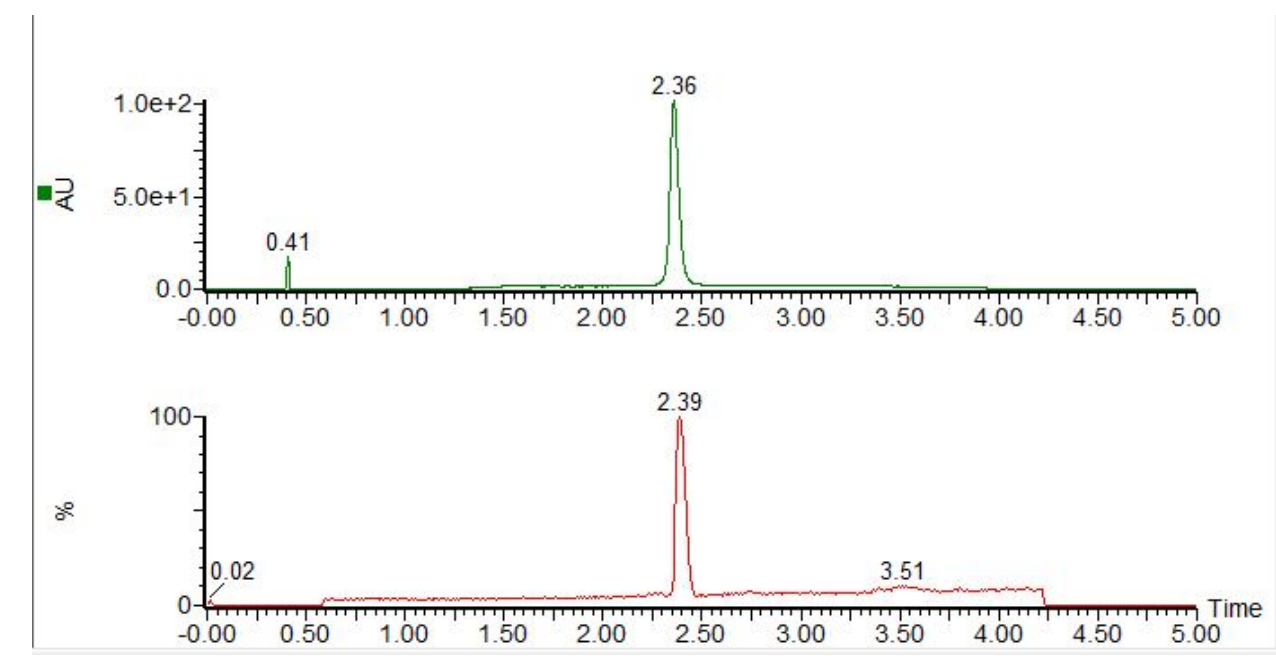

Figure 15. UV (190-400 $\mathrm{nm})$ and MS $(250-3000 \mathrm{~m} / \mathrm{z})$ traces from UPLC-MS analysis of purified WM68-b (gradient 5-95\% $\mathrm{CH}_{3} \mathrm{CN} / \mathrm{H}_{2} \mathrm{O}$ containing $0.1 \%$ TFA over $5 \mathrm{~min}$ at a flow rate of $0.4 \mathrm{~mL} / \mathrm{min}$ ). 


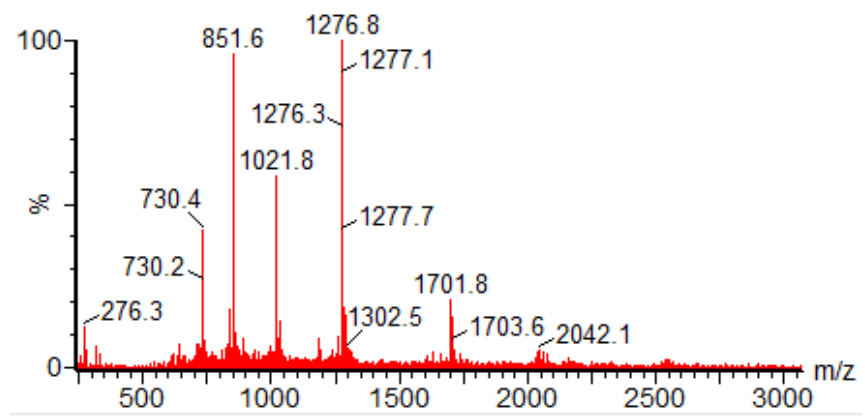

Figure 16. ESI-MS calcd. for $\mathrm{C}_{222} \mathrm{H}_{342} \mathrm{~N}_{58} \mathrm{O}_{80},[2 \mathrm{M}+5 \mathrm{H}]^{5+} \mathrm{m} / z=2042.4$, found $2042.1 ;[\mathrm{M}+3 \mathrm{H}]^{3+} \mathrm{m} / z=$ 1702.2, found 1701.8; $[\mathrm{M}+4 \mathrm{H}]^{4+} \mathrm{m} / \mathrm{z}=1276.9$, found 1276.8; $[\mathrm{M}+5 \mathrm{H}]^{5+} \mathrm{m} / \mathrm{z}=1021.7$, found 1021.8; $[\mathrm{M}+6 \mathrm{H}]^{6+} m / z=851.6$, found $851.6 ;[\mathrm{M}+7 \mathrm{H}]^{7+} m / z=730.1$, found 730.4 .

\subsection{Preparation of WM68}

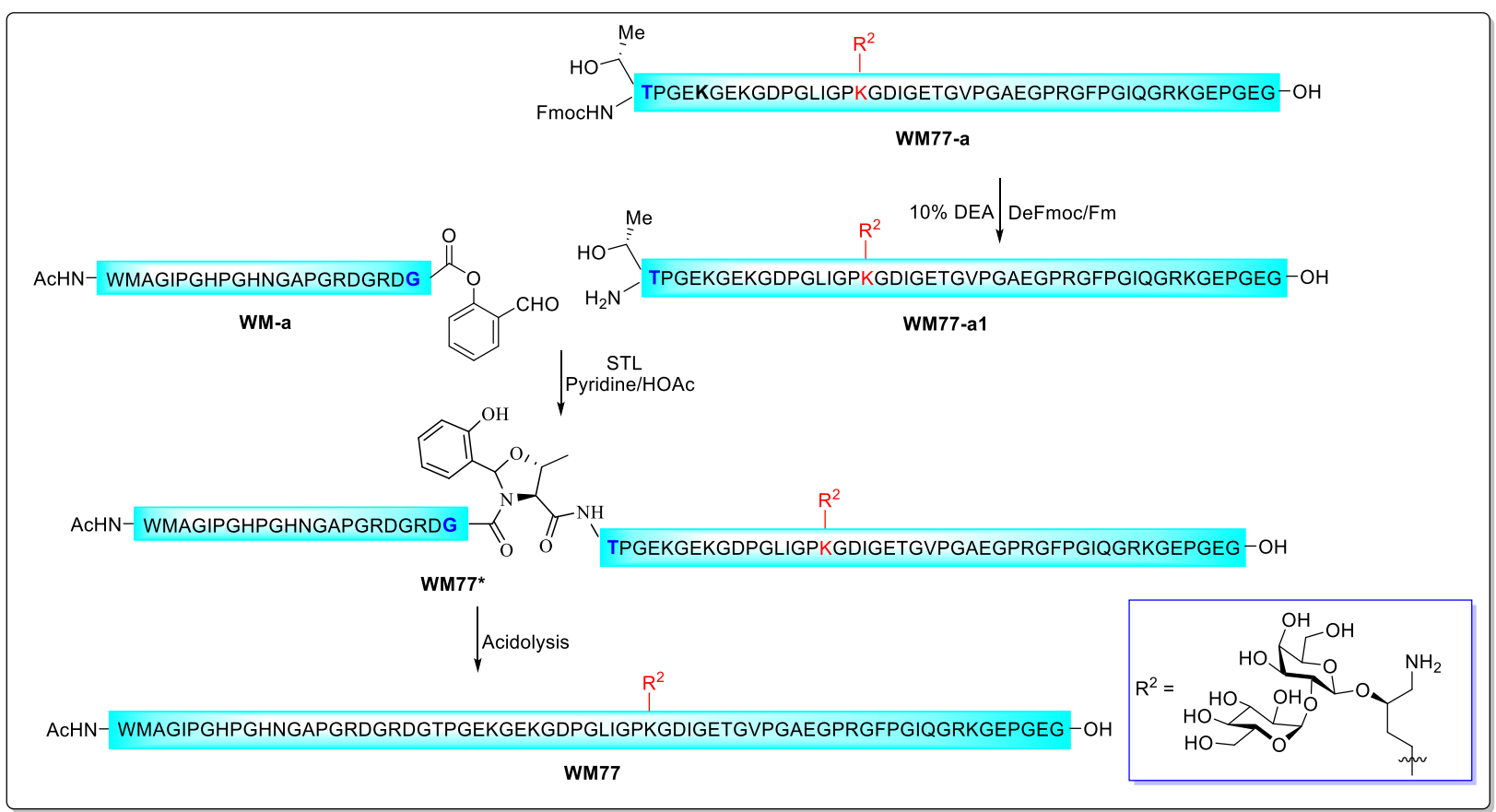


WM68-b (11.2 mg, $2.23 \mu \mathrm{mol})$ was dissolved in $250 \mu \mathrm{L} \mathrm{CH}_{3} \mathrm{CN} / \mathrm{H}_{2} \mathrm{O} /$ diethylamine $(4.5 / 4.5 / 1$, v/v/v) at room temperature and was stirred at room temperature for $2 \mathrm{~h}$ to give product WM68-b1. The reaction mixture was diluted with $50 \% \mathrm{CH}_{3} \mathrm{CN} / \mathrm{H}_{2} \mathrm{O}(20 \mathrm{~mL})$, and followed by concentration under reduced pressure and lyophilization to afford WM68-b1 as a slightly yellow solid. After that, WM68-b1 and WM-a (4.9 mg, $2.1 \mu \mathrm{mol})$ were dissolved in pyridine/acetic acid $(1 / 1$, mole/mole) buffer at a concentration of $15 \mathrm{mM}$ at room temperature. The reaction mixture was stirred at room temperature for 4 $\mathrm{h}$ to give ligation intermediate $\mathbf{W M 6 8}$, and the solvent was then blown off under a stream of condensed $\mathrm{N}_{2}$. The residue was treated with $1 \mathrm{~mL}$ TFA/ $\mathrm{H}_{2} \mathrm{O}(95 / 5, \mathrm{v} / \mathrm{v})$ for $10 \mathrm{~min}$ to obtain crude product WM68 and the volatile species were blown off under a stream of condensed $\mathrm{N}_{2}$. After that, the remaining residue was subjected to preparative HPLC purification $\left(10-35 \% \mathrm{CH}_{3} \mathrm{CN} / \mathrm{H}_{2} \mathrm{O}\right.$ over $45 \mathrm{~min}$ ) and followed by concentration under reduced pressure and lyophilization to afford WM68 (5.3 mg, 34\%) as a white powder.
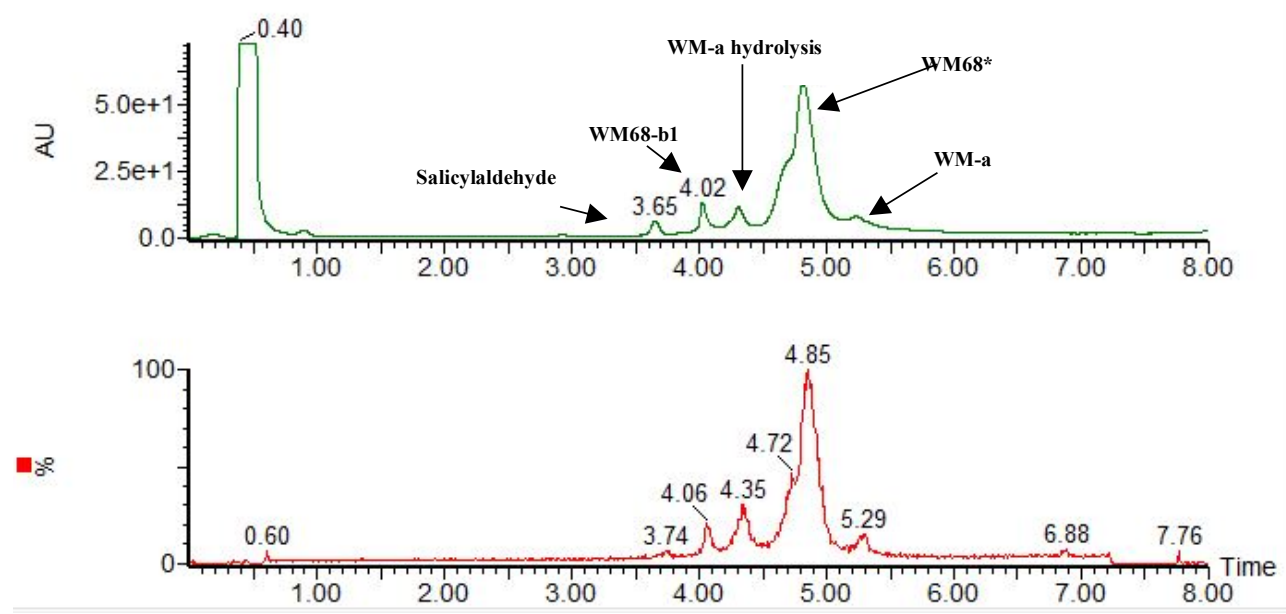

Figure 17. UV (190-400 nm) and MS (250-3000 m/z) traces from UPLC-MS analysis of STL between WM68-b1 and WM-a at $4 \mathrm{~h}$ (gradient $10-50 \% \mathrm{CH}_{3} \mathrm{CN} / \mathrm{H}_{2} \mathrm{O}$ containing $0.1 \%$ TFA over 8 min at a flow rate of $0.4 \mathrm{~mL} / \mathrm{min})$. 


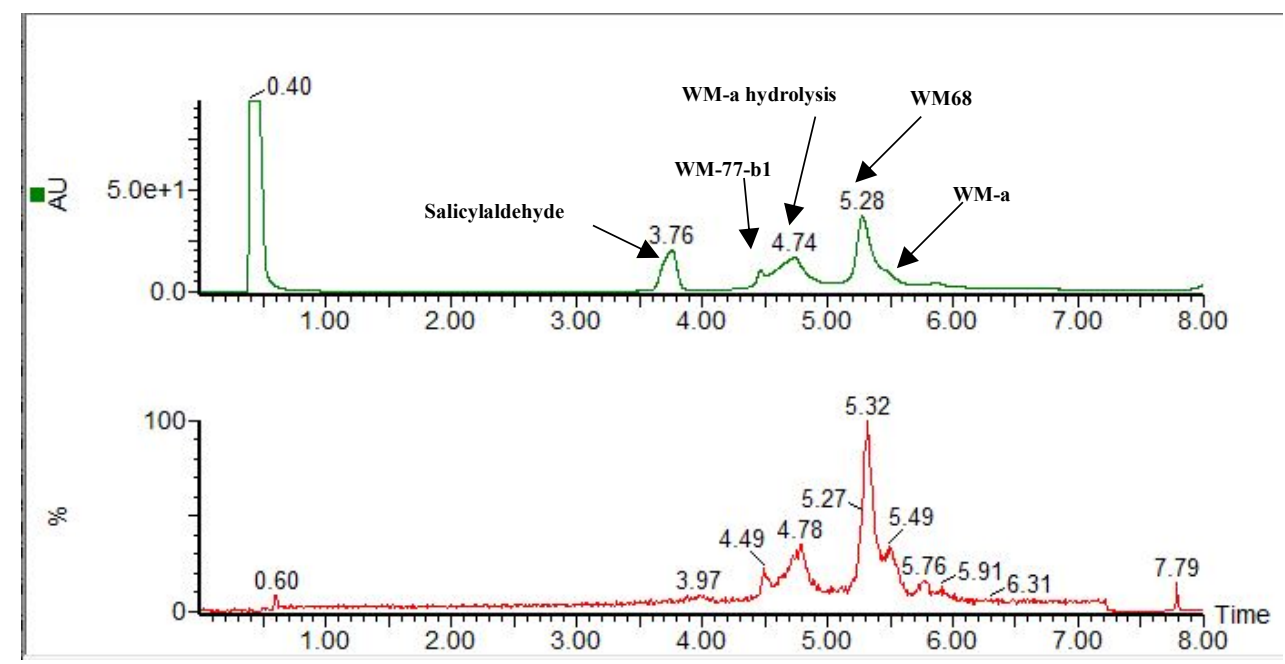

Figure 18. UV (190-400 nm) and MS (250-3000 m/z) traces from UPLC-MS analysis of acidolysis of STL between WM68-b1 and WM-a at $4 \mathrm{~h}$ (gradient 10-35\% $\mathrm{CH}_{3} \mathrm{CN} / \mathrm{H}_{2} \mathrm{O}$ containing $0.1 \%$ TFA over 8 min at a flow rate of $0.4 \mathrm{~mL} / \mathrm{min}$ ).

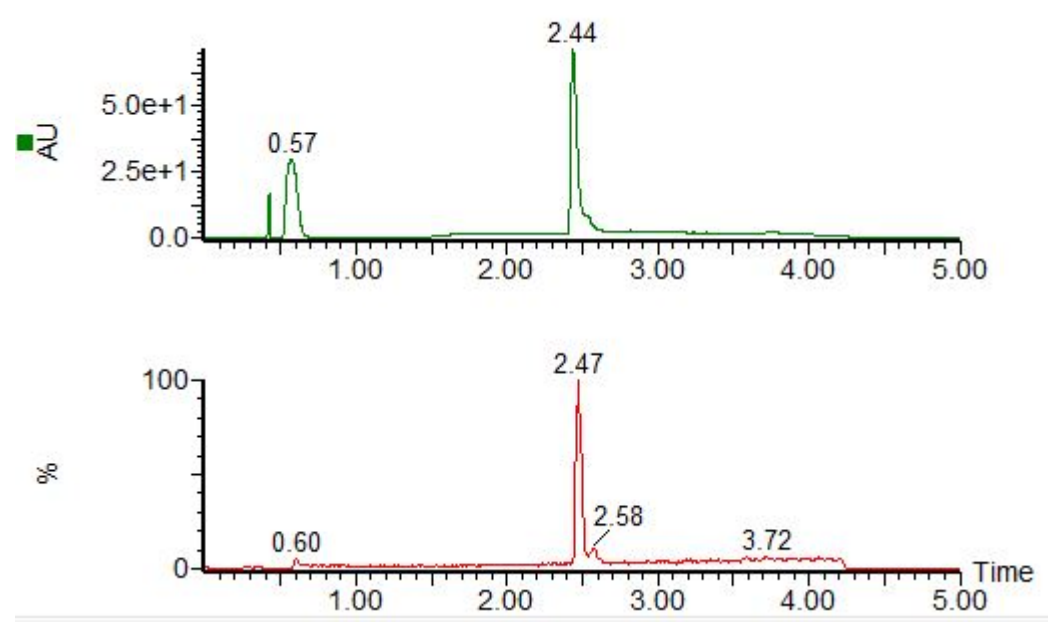

Figure 19. UV (190-400 nm) and MS (250-3000 m/z) traces from UPLC-MS analysis of purified WM68 (gradient 5-95\% $\mathrm{CH}_{3} \mathrm{CN} / \mathrm{H}_{2} \mathrm{O}$ containing $0.1 \%$ TFA over $5 \mathrm{~min}$ at a flow rate of $0.4 \mathrm{~mL} / \mathrm{min}$ ). 


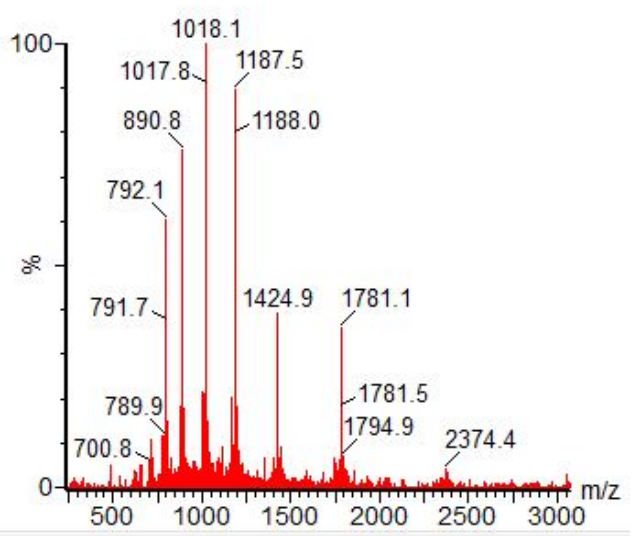

Figure 20. ESI-MS calcd. for $\mathrm{C}_{302} \mathrm{H}_{470} \mathrm{~N}_{92} \mathrm{O}_{106} \mathrm{~S}$, $[\mathrm{M}+3 \mathrm{H}]^{3+} \mathrm{m} / z=2373.6$, found 2374.4; $[\mathrm{M}+4 \mathrm{H}]^{4+} \mathrm{m} / z=$ 1780.5, found 1781.1; $[\mathrm{M}+5 \mathrm{H}]^{5+} \mathrm{m} / z=1424.5$, found $1424.9 ;[\mathrm{M}+6 \mathrm{H}]^{6+} \mathrm{m} / z=1187.3$, found 1187.5 ; $[\mathrm{M}+7 \mathrm{H}]^{7+} m / z=1017.8$, found 1017.8; $[\mathrm{M}+8 \mathrm{H}]^{8+} \mathrm{m} / z=890.7$, found $890.8 ;[\mathrm{M}+9 \mathrm{H}]^{9+} \mathrm{m} / z=791.9$, found 791.7.

\section{Synthesis of peptide WM-77}

\subsection{Preparation of WM77b}

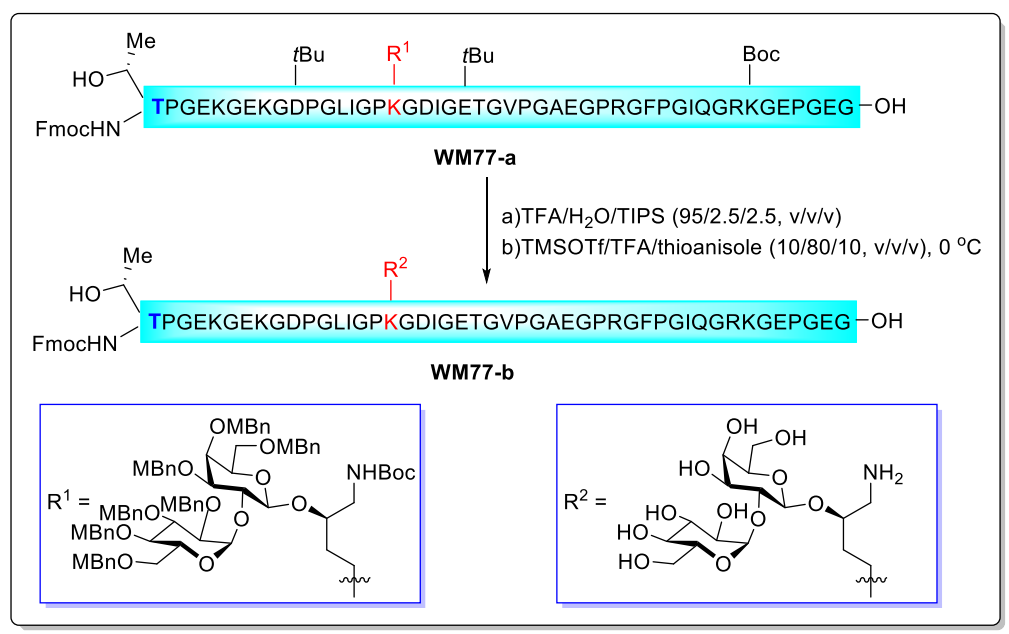


Peptide WM77-a was synthesized according to the general procedure A using 2-chlorotrityl chloride resin $(50 \mathrm{mg})$ by introducing the glycosylated 5-hydroxylysine building-block at specific position. Upon completion of synthesis, the crude peptide was then deprotected and cleaved from the resin using $5 \mathrm{~mL}$ TFA/TIPS/ $\mathrm{H}_{2} \mathrm{O}(90: 5: 5, \mathrm{v} / \mathrm{v} / \mathrm{v})$ for $1 \mathrm{~h}$. The resin was filtered and the combined filtrate was stirred at -10 ${ }^{\circ} \mathrm{C}$ in cooling bath for $10 \mathrm{~min}$. Then, thioanisole $625 \mu \mathrm{L}$ was added to the above solution and stirred for an additional $10 \mathrm{~min}$. TMSOTf $625 \mu \mathrm{L}$ was slowly added to the above solution and stirred at $-10{ }^{\circ} \mathrm{C}$ for 45 min. The reaction solution was poured into a cold $\left(-20{ }^{\circ} \mathrm{C}\right)$ diethyl ether $(45 \mathrm{~mL})$, and the resulting suspension was centrifuged to give a white pellet. After decanting diethyl ether, the remaining solid was dissolved in $2 \mathrm{~mL} 50 \% \mathrm{CH}_{3} \mathrm{CN} / \mathrm{H}_{2} \mathrm{O}$, and $\mathrm{NH}_{4} \mathrm{HCO}_{3}$ solid was added until the solution $\mathrm{pH}$ to 7 . The resulting solution was stirred at room temperature for $1 \mathrm{~h}$ and subjected to preparative HPLC purification (20-50\% $\mathrm{CH}_{3} \mathrm{CN} / \mathrm{H}_{2} \mathrm{O}$ over $\left.45 \mathrm{~min}\right)$. Lyophilization afforded WM77-b (11.4 $\mathrm{mg}, 8.9 \%$ ) as a white powder.

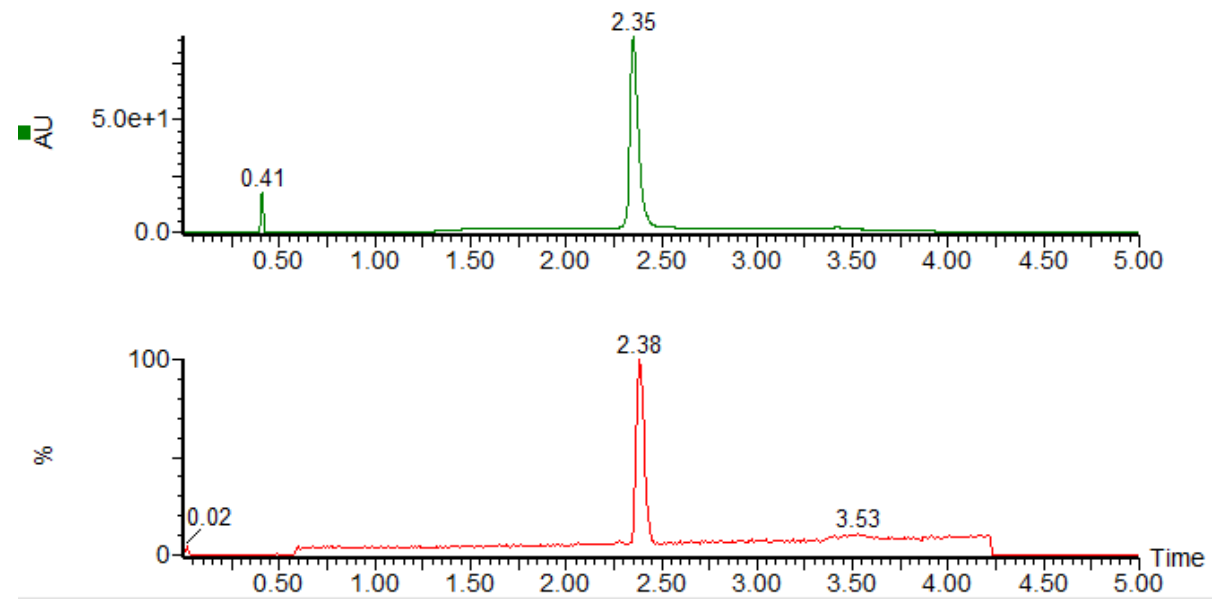

Figure 21. UV (190-400 nm) and MS (250-3000 m/z) traces from UPLC-MS analysis of purified WM77-b (gradient 5-95\% $\mathrm{CH}_{3} \mathrm{CN} / \mathrm{H}_{2} \mathrm{O}$ containing $0.1 \%$ TFA over $5 \mathrm{~min}$ at a flow rate of $0.4 \mathrm{~mL} / \mathrm{min}$ ). 


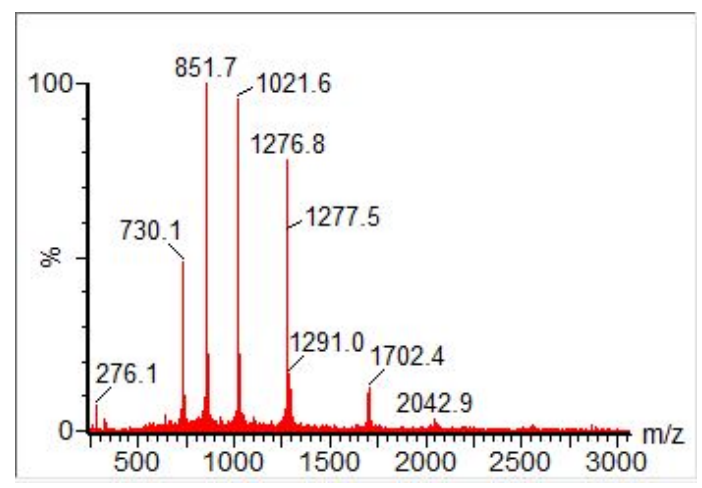

Figure 22. ESI-MS calcd. for $\mathrm{C}_{222} \mathrm{H}_{342} \mathrm{~N}_{58} \mathrm{O}_{80},[2 \mathrm{M}+5 \mathrm{H}]^{5+} \mathrm{m} / z=2042.4$, found 2042.9; $[\mathrm{M}+3 \mathrm{H}]^{3+} \mathrm{m} / z$ $=1702.2$, found 1702.4; $[\mathrm{M}+4 \mathrm{H}]^{4+} m / z=1276.9$, found 1276.8; $[\mathrm{M}+5 \mathrm{H}]^{5+} \mathrm{m} / z=1021.7$, found 1021.6; $[\mathrm{M}+6 \mathrm{H}]^{6+} m / z=851.6$, found $851.7 ;[\mathrm{M}+7 \mathrm{H}]^{7+} m / z=730.1$, found 730.1 .

\subsection{Preparation of WM77}

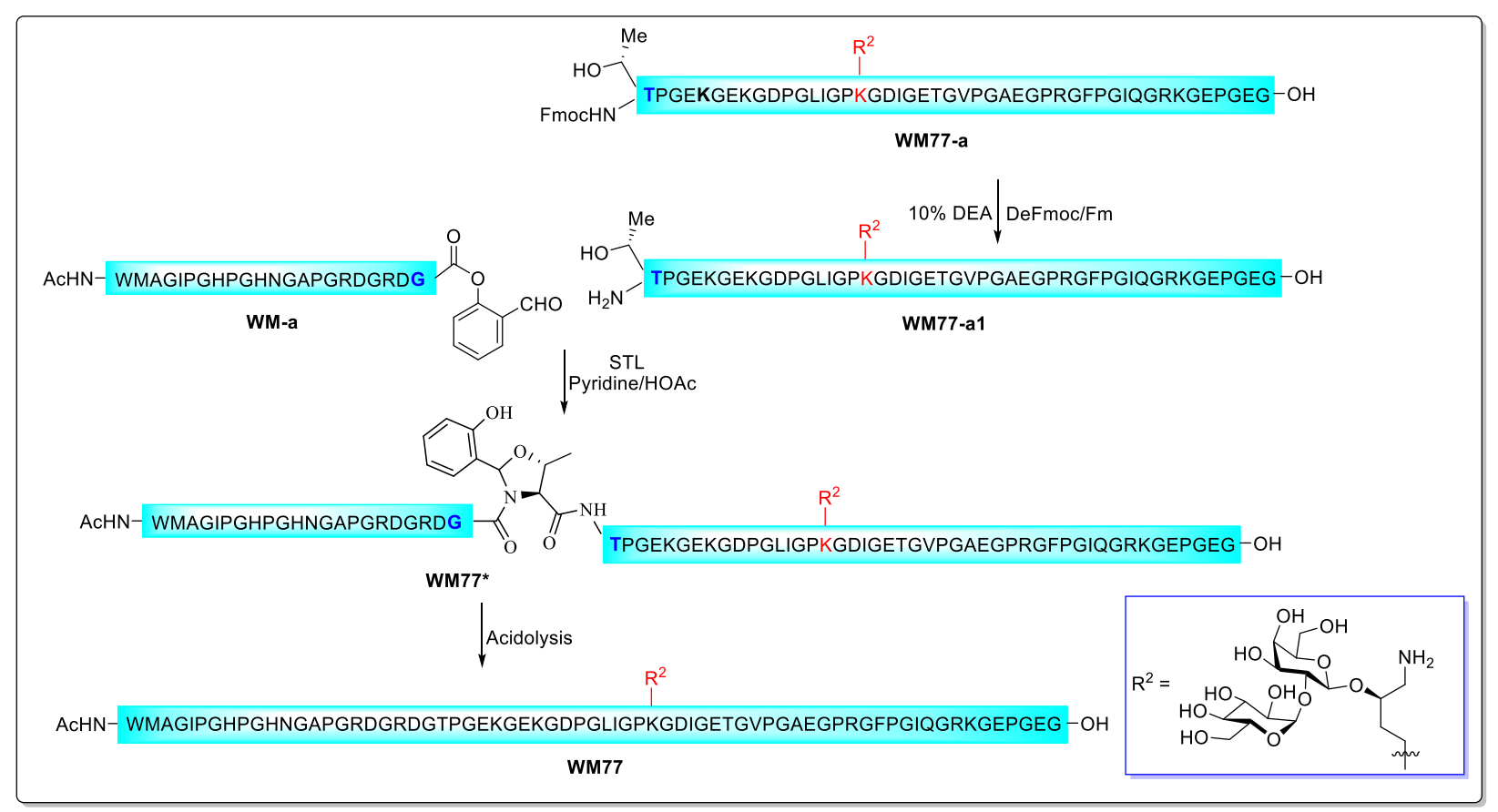


WM77-b (11.4 mg, $2.23 \mu \mathrm{mol})$ was dissolved in $250 \mu \mathrm{L} \mathrm{CH}_{3} \mathrm{CN} / \mathrm{H}_{2} \mathrm{O} /$ diethylamine $(4.5 / 4.5 / 1$, v/v/) at room temperature and stirred at room temperature for $2 \mathrm{~h}$ to give product WM77-b1. The reaction mixture was diluted with $50 \% \mathrm{CH}_{3} \mathrm{CN} / \mathrm{H}_{2} \mathrm{O}(20 \mathrm{~mL})$ and subjected to lyophilization to afford WM77-b1 as a slightly yellow solid. This crude peptide was washed by diethyl ether. After that, WM77-b1 and WM-a $(5.3 \mathrm{mg}, 2.23 \mu \mathrm{mol})$ were dissolved in pyridine/acetic acid (1/1, mole/mole) buffer at a concentration of $15 \mathrm{mM}$ at room temperature. The reaction mixture was stirred at room temperature for 4 $\mathrm{h}$ to give ligation intermediate $\mathbf{W M} \mathbf{3 7}{ }^{*}$, and the solvent was then blown off under a stream of condensed $\mathrm{N}_{2}$. The residue was treated with $1 \mathrm{~mL}$ TFA/ $\mathrm{H}_{2} \mathrm{O}(95 / 5, \mathrm{v} / \mathrm{v})$ for 20 min to obtain crude product WM77, and the volatile species were blown off under a stream of condensed $\mathrm{N}_{2}$. The remaining residue was subjected to preparative HPLC purification $\left(10-35 \% \mathrm{CH}_{3} \mathrm{CN} / \mathrm{H}_{2} \mathrm{O}\right.$ over $\left.45 \mathrm{~min}\right)$ and lyophilization to afford WM77 (4.9 mg, 31\%) as a white powder.

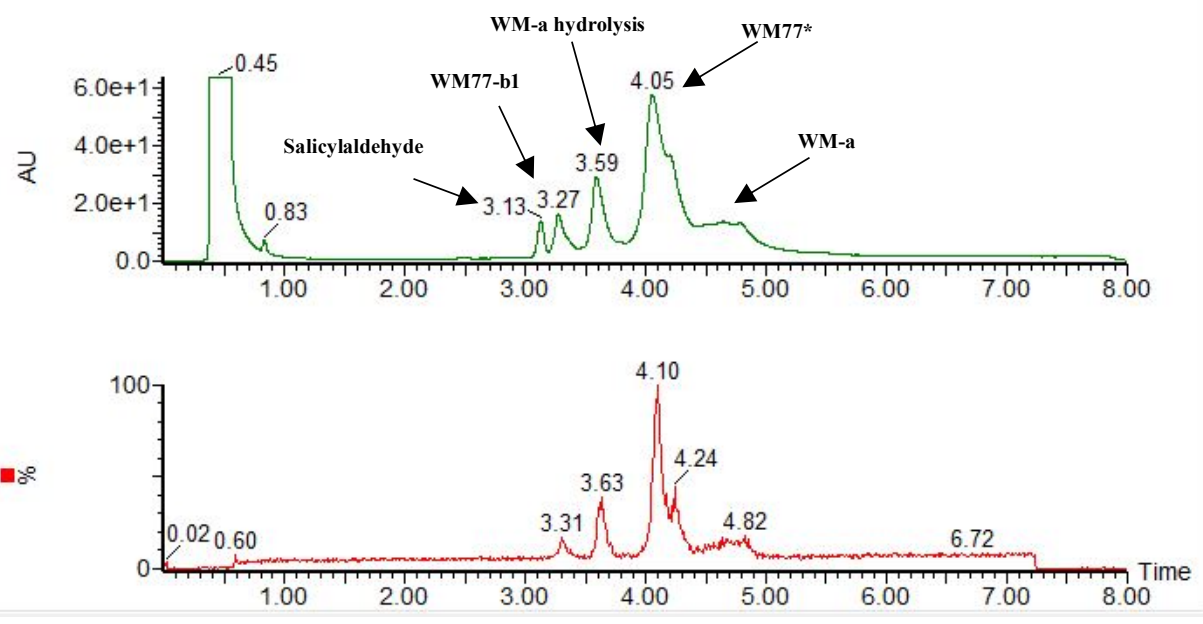

Figure 23. UV (190-400 nm) and MS (250-3000 m/z) traces from UPLC-MS analysis of STL between WM77-b1 and WM-a at $4 \mathrm{~h}$ (gradient $10-50 \% \mathrm{CH}_{3} \mathrm{CN} / \mathrm{H}_{2} \mathrm{O}$ containing $0.1 \%$ TFA over 8 min at a flow rate of $0.4 \mathrm{~mL} / \mathrm{min}$ ). 

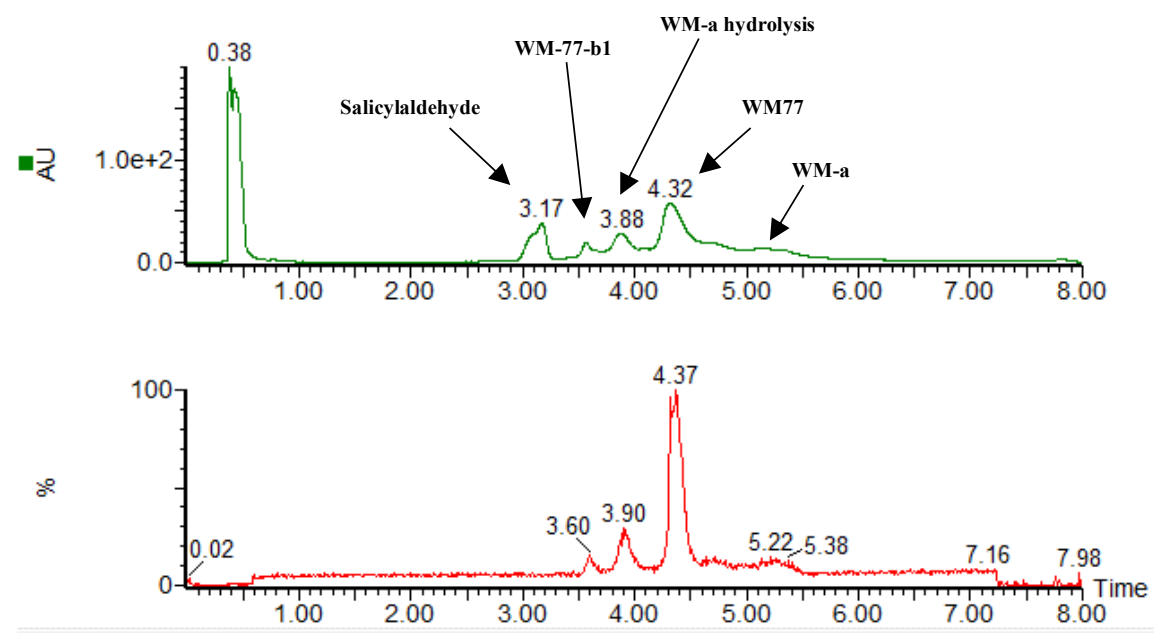

Figure 24. UV (190-400 nm) and MS (250-3000 m/z) traces from UPLC-MS analysis of acidolysis of STL between WM77-b1 and WM-a at $4 \mathrm{~h}$ (gradient $10-35 \% \mathrm{CH}_{3} \mathrm{CN} / \mathrm{H}_{2} \mathrm{O}$ containing $0.1 \%$ TFA over 8 $\min$ at a flow rate of $0.4 \mathrm{~mL} / \mathrm{min}$ ).
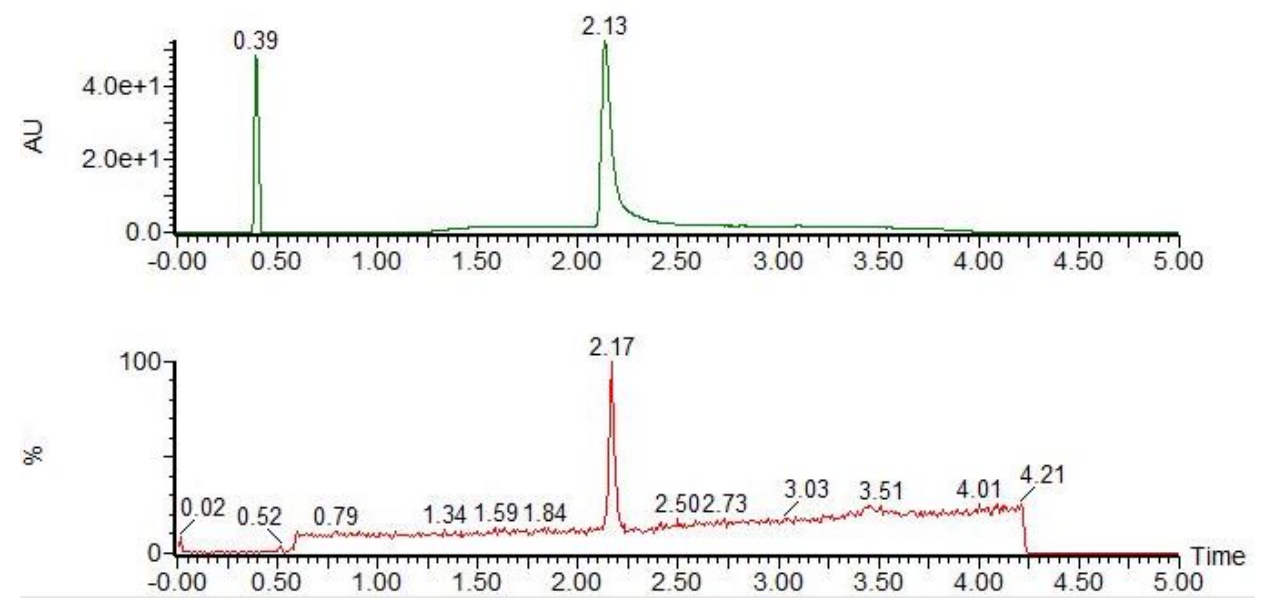

Figure 25. UV (190-400 nm) and MS (250-3000 m/z) traces from UPLC-MS analysis of purified WM77 (gradient 5-95\% $\mathrm{CH}_{3} \mathrm{CN} / \mathrm{H}_{2} \mathrm{O}$ containing $0.1 \%$ TFA over $5 \mathrm{~min}$ at a flow rate of $0.4 \mathrm{~mL} / \mathrm{min}$ ). 


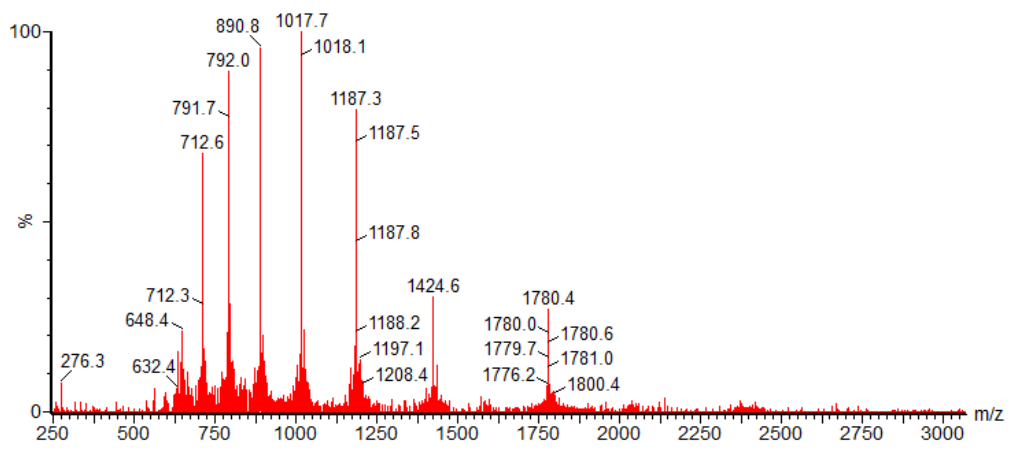

Figure 26. ESI-MS calcd. for $\mathrm{C}_{302} \mathrm{H}_{470} \mathrm{~N}_{92} \mathrm{O}_{106} \mathrm{~S}$, $[\mathrm{M}+4 \mathrm{H}]^{4+} \mathrm{m} / z=1780.4$, found 1780.4; $[\mathrm{M}+5 \mathrm{H}]^{5+} \mathrm{m} / z$ $=1424.5$, found 1424.6; $[\mathrm{M}+6 \mathrm{H}]^{6+} m / z=1187.3$, found 1187.3; $[\mathrm{M}+7 \mathrm{H}]^{7+} m / z=1017.8$, found 1017.7; $[\mathrm{M}+8 \mathrm{H}]^{8+} \mathrm{m} / \mathrm{z}=890.7$, found $890.8 ;[\mathrm{M}+9 \mathrm{H}]^{9+} \mathrm{m} / \mathrm{z}=791.8$, found $791.7 ;[\mathrm{M}+10 \mathrm{H}]^{10+} \mathrm{m} / \mathrm{z}=712.8$, found 712.8; $[\mathrm{M}+11 \mathrm{H}]^{11+} m / z=648.1$, found 648.4 .

\section{Synthesis of peptide WM-101}

\subsection{Preparation of WM101b}

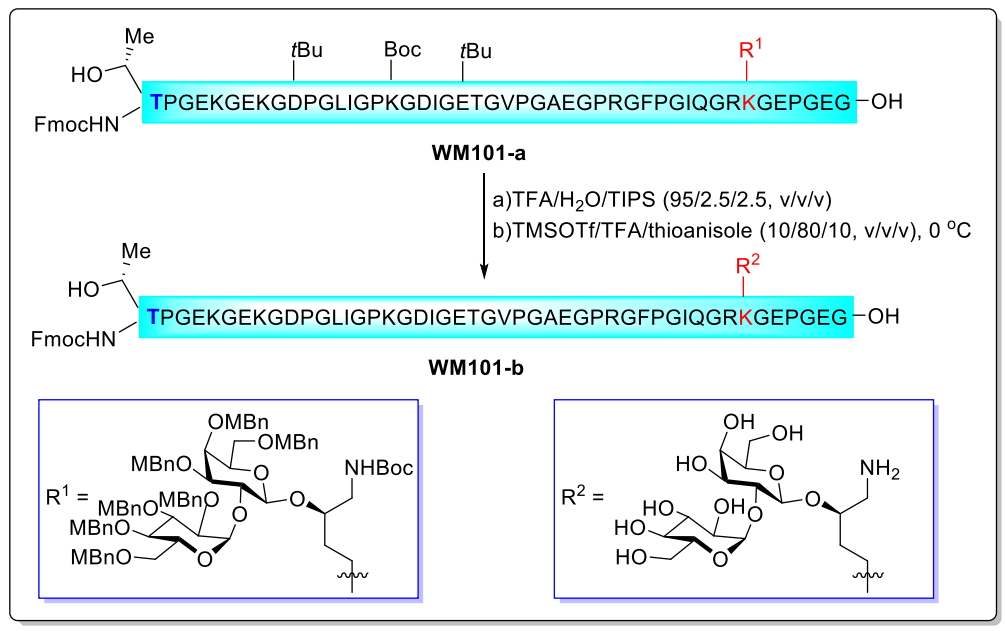

Peptide WM101-a was synthesized according to the general procedure A using 2-chlorotrityl chloride resin $(50 \mathrm{mg})$ by introducing the glycosylated 5-hydroxylysine building-block at specific position. Upon 
completion of synthesis, the crude peptide was then deprotected and cleaved from the resin using $5 \mathrm{~mL}$ TFA/TIPS/ $\mathrm{H}_{2} \mathrm{O}(90: 5: 5, \mathrm{v} / \mathrm{v} / \mathrm{v})$ for $1 \mathrm{~h}$. The resin was filtered and the combined filtrate was stirred at -10 ${ }^{\circ} \mathrm{C}$ in cooling bath for $10 \mathrm{~min}$. Then, thioanisole $625 \mu \mathrm{L}$ was added to the above solution and stirred for an additional $10 \mathrm{~min}$. TMSOTf $625 \mu \mathrm{L}$ was slowly added to the above solution and stirred at $-10{ }^{\circ} \mathrm{C}$ for 45 min. The reaction solution was poured into a cold $\left(-20{ }^{\circ} \mathrm{C}\right)$ diethyl ether $(45 \mathrm{~mL})$, and the resulting suspension was centrifuged to give a white pellet. After decanting diethyl ether, the remaining solid was dissolved in $2 \mathrm{~mL} 50 \% \mathrm{CH}_{3} \mathrm{CN} / \mathrm{H}_{2} \mathrm{O}$ and $\mathrm{NH}_{4} \mathrm{HCO}_{3}$ solid was added until the solution $\mathrm{pH}$ to 7 . The resulting solution was stirred at room temperature for $1 \mathrm{~h}$ and subjected to preparative HPLC purification (20-50\% $\mathrm{CH}_{3} \mathrm{CN} / \mathrm{H}_{2} \mathrm{O}$ over $\left.45 \mathrm{~min}\right)$. Lyophilization afforded WM101-b (8.9 $\mathrm{mg}$, 7\%) as a white powder.
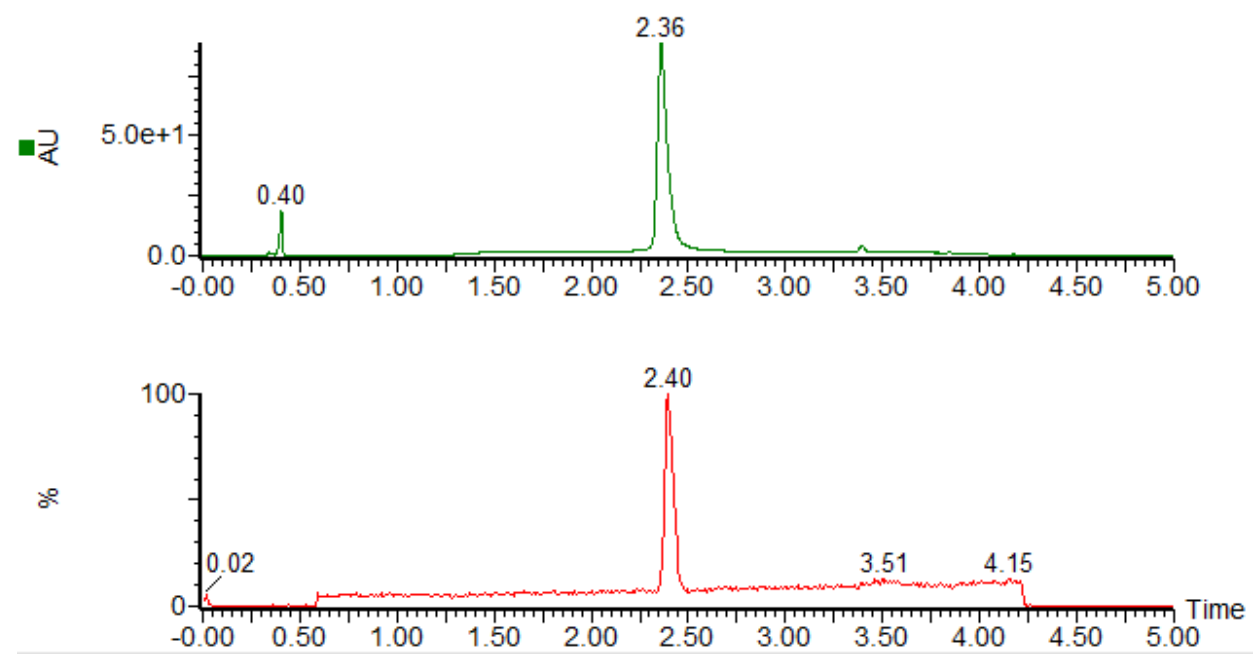

Figure 27. UV (190-400 nm) and MS (250-3000 m/z) traces from UPLC-MS analysis of purified WM101-a (gradient 5-95\% $\mathrm{CH}_{3} \mathrm{CN} / \mathrm{H}_{2} \mathrm{O}$ containing $0.1 \%$ TFA over $5 \mathrm{~min}$ at a flow rate of $0.4 \mathrm{~mL} / \mathrm{min}$ ). 


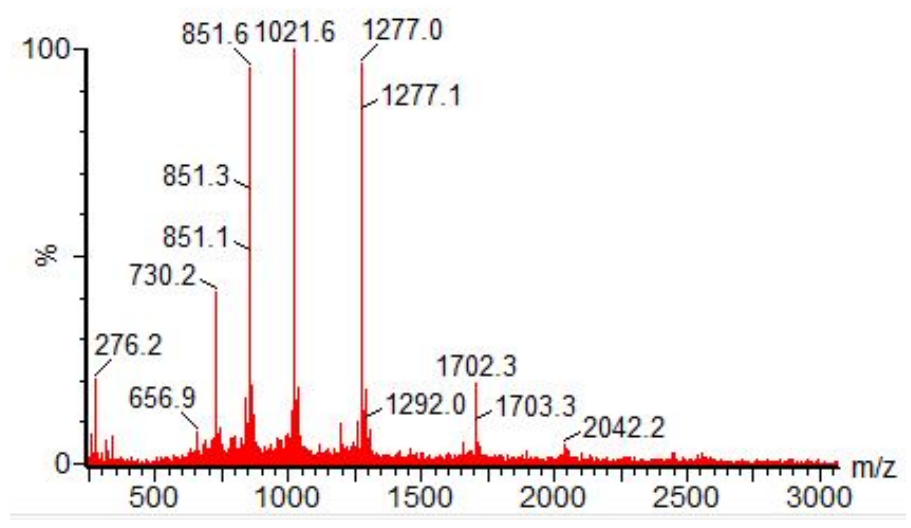

Figure 28. ESI-MS calcd. for $\mathrm{C}_{222} \mathrm{H}_{342} \mathrm{~N}_{58} \mathrm{O}_{80},[2 \mathrm{M}+5 \mathrm{H}]^{5+} \mathrm{m} / z=2042.9$, found 2042.2; $[\mathrm{M}+3 \mathrm{H}]^{3+} \mathrm{m} / z$ $=1702.2$, found 1702.3; $[\mathrm{M}+4 \mathrm{H}]^{4+} m / z=1276.9$, found 1277.0; $[\mathrm{M}+5 \mathrm{H}]^{5+} m / z=1021.7$, found 1021.6; $[\mathrm{M}+6 \mathrm{H}]^{6+} m / z=851.6$, found $851.6 ;[\mathrm{M}+7 \mathrm{H}]^{7+} m / z=730.1$, found 730.2 .

\subsection{Preparation of WM101}

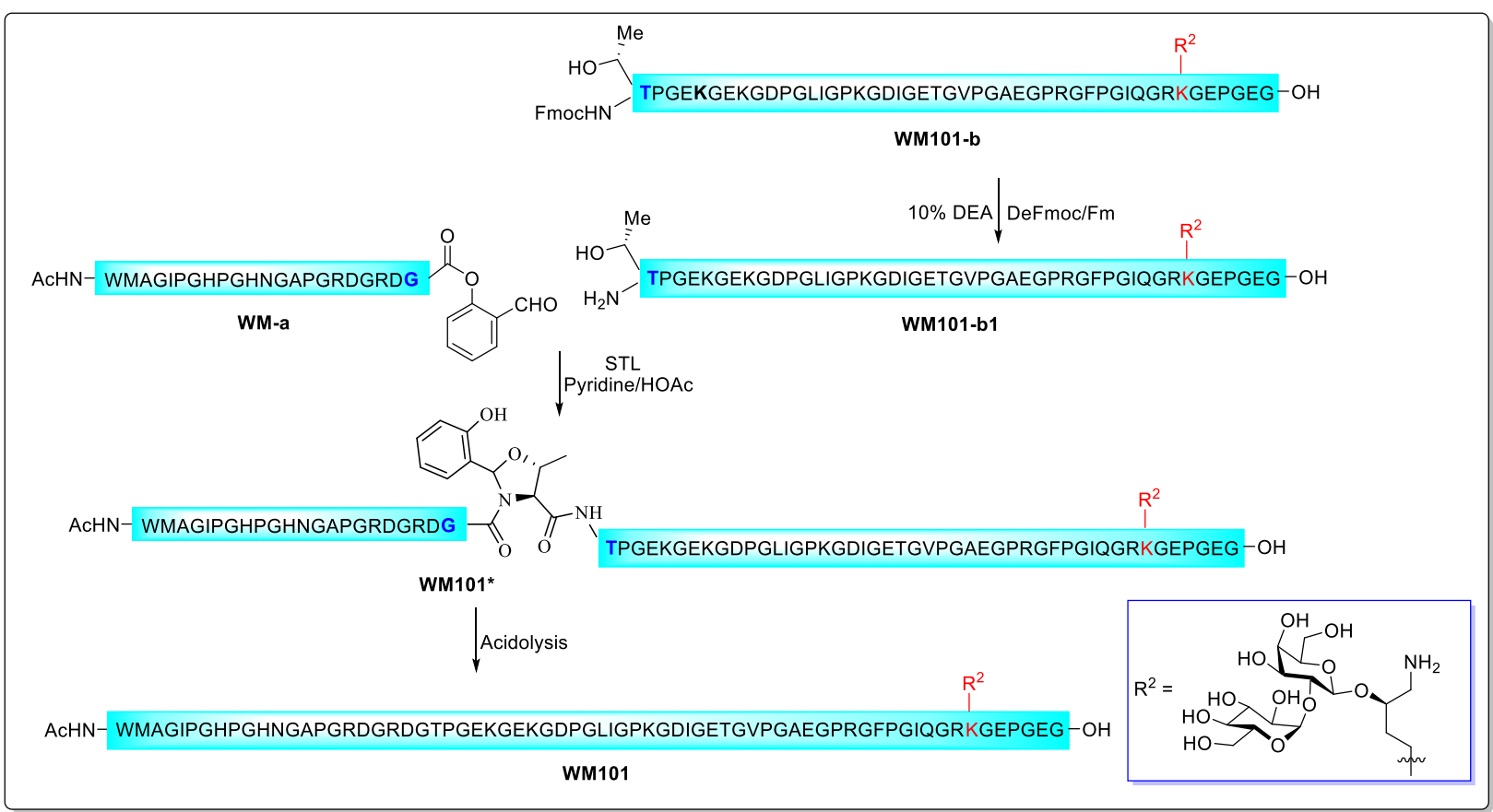


WM101-b (8.9 mg, $1.74 \mu \mathrm{mol})$ was dissolved in $200 \mu \mathrm{L} \mathrm{CH}_{3} \mathrm{CN} / \mathrm{H}_{2} \mathrm{O} /$ diethylamine $(4.5 / 4.5 / 1$, v/v/v) at room temperature and stirred at room temperature for $2 \mathrm{~h}$ to give product WM101-b1. The reaction mixture was diluted with $50 \% \mathrm{CH}_{3} \mathrm{CN} / \mathrm{H}_{2} \mathrm{O}(20 \mathrm{~mL})$ and subjected to lyophilization to afford WM101-b1 as a slightly yellow solid. This crude peptide was washed by diethyl ether. After that, WM101-b1 and WM-a (4.1 mg, $1.74 \mu \mathrm{mol})$ were dissolved in pyridine/acetic acid $(1 / 1$, mole/mole) buffer at a concentration of $15 \mathrm{mM}$ at room temperature. The reaction mixture was stirred at room temperature for 4 $\mathrm{h}$ to give ligation intermediate WM101*, and the solvent was then blown off under a stream of condensed $\mathrm{N}_{2}$. The residue was treated with $1 \mathrm{~mL} \mathrm{TFA} / \mathrm{H}_{2} \mathrm{O}(95 / 5, \mathrm{v} / \mathrm{v})$ for $20 \mathrm{~min}$ to obtain crude product WM101, and the TFA was blown off under a stream of condensed $\mathrm{N}_{2}$. The remaining residue was subjected to preparative HPLC purification (10-35\% $\mathrm{CH}_{3} \mathrm{CN} / \mathrm{H}_{2} \mathrm{O}$ over $45 \mathrm{~min}$ ) and lyophilization to afford WM101 $(5.2 \mathrm{mg}, 43 \%)$ as a white powder.

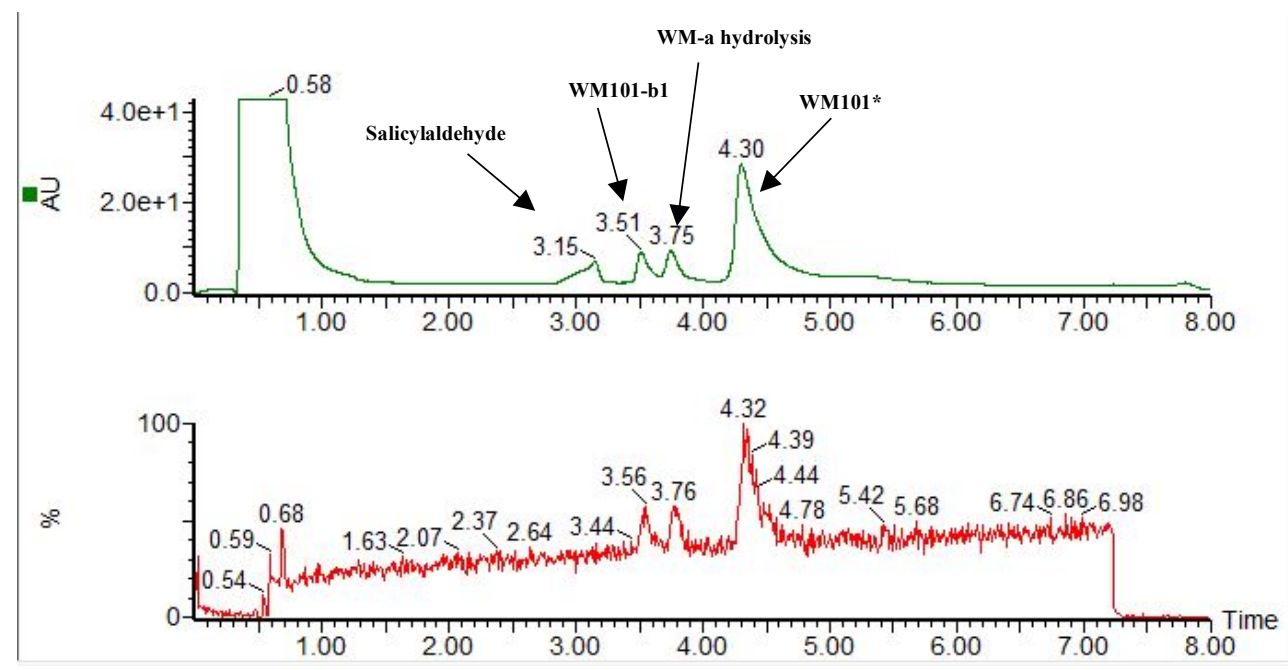

Figure 29. UV (190-400 $\mathrm{nm})$ and MS (250-3000 m/z) traces from UPLC-MS analysis of STL between WM101-b1 and WM-a at $4 \mathrm{~h}$ (gradient $10-50 \% \mathrm{CH}_{3} \mathrm{CN} / \mathrm{H}_{2} \mathrm{O}$ containing $0.1 \%$ TFA over 8 min at a flow rate of $0.4 \mathrm{~mL} / \mathrm{min})$. 

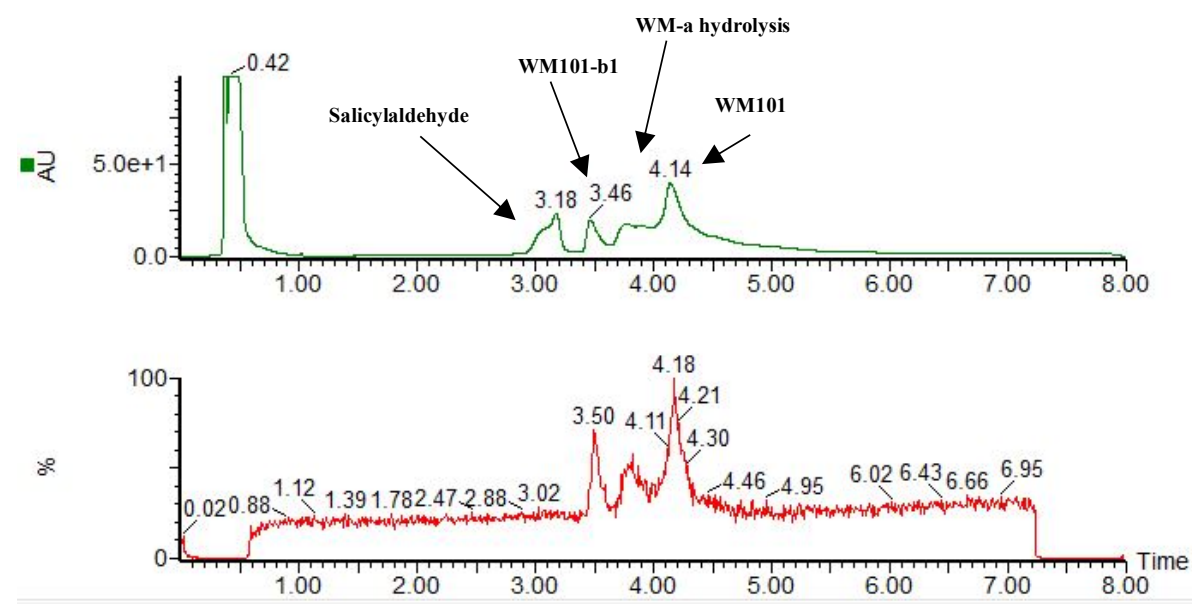

Figure 30. UV (190-400 nm) and MS (250-3000 m/z) traces from UPLC-MS analysis of STL acidolysis between WM101-b1 and WM-a at $4 \mathrm{~h}$ (gradient 10-50\% $\mathrm{CH}_{3} \mathrm{CN} / \mathrm{H}_{2} \mathrm{O}$ containing $0.1 \%$ TFA over 8 min at a flow rate of $0.4 \mathrm{~mL} / \mathrm{min}$ ).

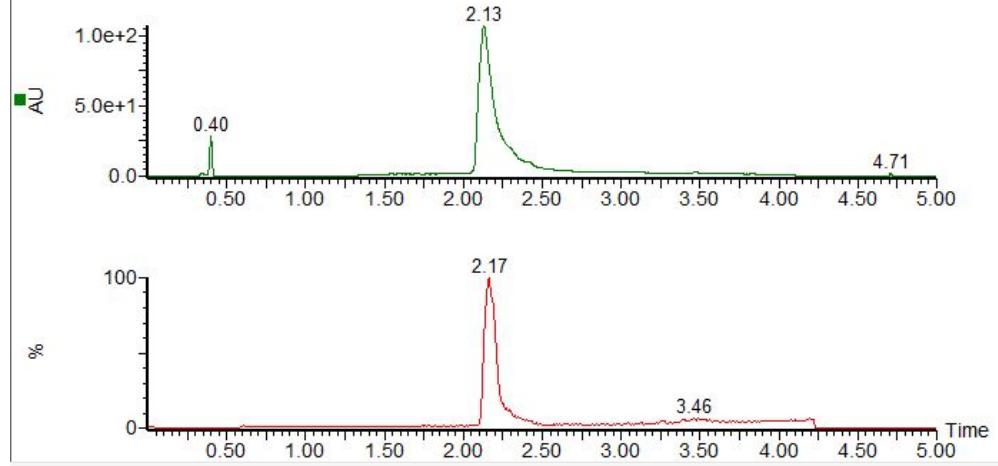

Figure 31. UV (190-400 $\mathrm{nm})$ and MS $(250-3000 \mathrm{~m} / \mathrm{z})$ traces from UPLC-MS analysis of purified WM101 (gradient 5-95\% $\mathrm{CH}_{3} \mathrm{CN} / \mathrm{H}_{2} \mathrm{O}$ containing $0.1 \%$ TFA over $5 \mathrm{~min}$ at a flow rate of $0.4 \mathrm{~mL} / \mathrm{min}$ ). 


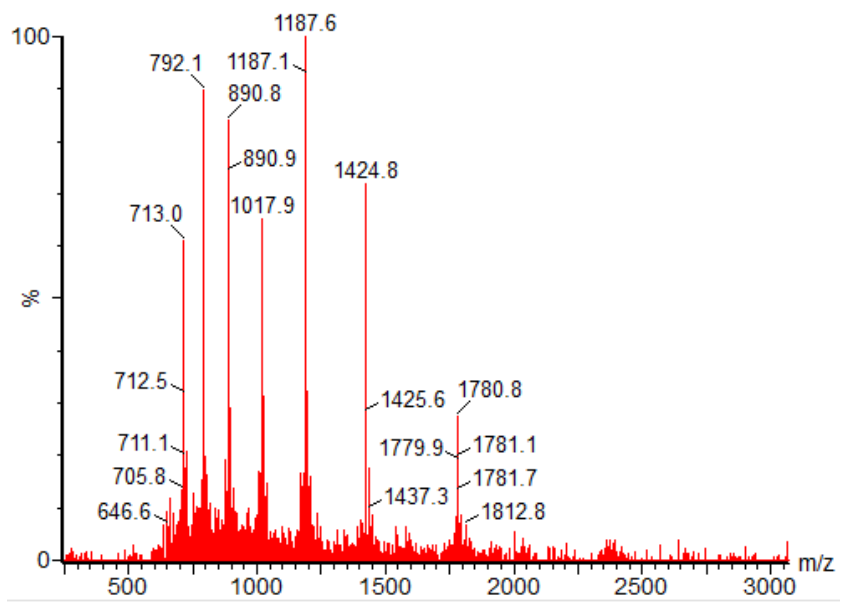

Figure 32. ESI-MS calcd. for $\mathrm{C}_{302} \mathrm{H}_{470} \mathrm{~N}_{92} \mathrm{O}_{106} \mathrm{~S}$, $[\mathrm{M}+4 \mathrm{H}]^{4+} \mathrm{m} / z=1780.4$, found 1780.8 ; $[\mathrm{M}+5 \mathrm{H}]^{5+} \mathrm{m} / z=$ 1424.5, found 1424.8; $[\mathrm{M}+6 \mathrm{H}]^{6+} \mathrm{m} / z=1187.3$, found 1187.6; $[\mathrm{M}+7 \mathrm{H}]^{7+} \mathrm{m} / z=1017.8$, found 1017.9; $[\mathrm{M}+8 \mathrm{H}]^{8+} \mathrm{m} / \mathrm{z}=890.7$, found $890.8 ;[\mathrm{M}+9 \mathrm{H}]^{9+} \mathrm{m} / \mathrm{z}=791.9$, found $792.1 ;[\mathrm{M}+10 \mathrm{H}]^{10+} \mathrm{m} / \mathrm{z}=712.8$, found 713.0.

\section{Synthesis of peptide WM-6568}

\subsection{Preparation of WM6568b}

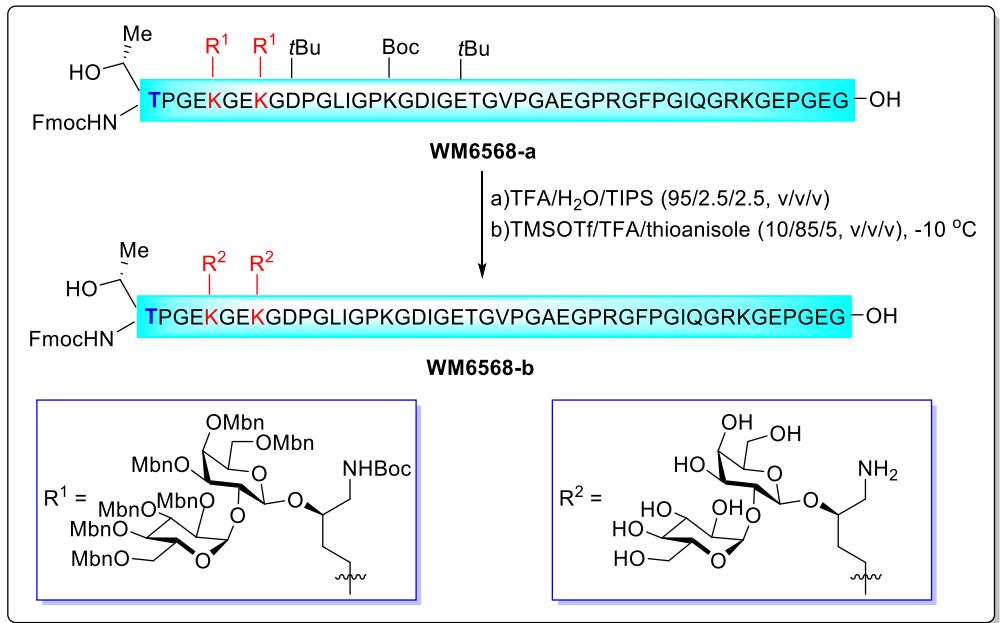


Peptide WM6568-a was synthesized according to the general procedure A using 2-chlorotrityl chloride resin $(50 \mathrm{mg})$ by introducing the glycosylated 5-hydroxylysine building-block at desired positions. Upon completion of synthesis, the crude peptide was then deprotected and cleaved from the resin using $5 \mathrm{~mL}$ TFA/TIPS/ $\mathrm{H}_{2} \mathrm{O}(90: 5: 5, \mathrm{v} / \mathrm{v} / \mathrm{v})$ for $1 \mathrm{~h}$. The resin was filtered and the combined filtrate was stirred at $-10{ }^{\circ} \mathrm{C}$ in cooling bath for $10 \mathrm{~min}$. Then, thioanisole $625 \mu \mathrm{L}$ was added to the above solution and stirred for an additional $10 \mathrm{~min}$. TMSOTf $625 \mu \mathrm{L}$ was slowly added to the above solution and stirred at $-10{ }^{\circ} \mathrm{C}$ for $45 \mathrm{~min}$. The reaction solution was poured into cold $\left(-20^{\circ} \mathrm{C}\right)$ diethyl ether $(45 \mathrm{~mL})$, and the resulting suspension was centrifuged to give a white pellet. After decanting diethyl ether, the remaining solid was dissolved in $2 \mathrm{~mL} 50 \% \mathrm{CH}_{3} \mathrm{CN} / \mathrm{H}_{2} \mathrm{O}$ and $\mathrm{NH}_{4} \mathrm{HCO}_{3}$ solid was added until the solution $\mathrm{pH}$ became 7 . The resulting solution was stirred at room temperature for $1 \mathrm{~h}$ and subjected to preparative HPLC purification (20-50\% $\mathrm{CH}_{3} \mathrm{CN} / \mathrm{H}_{2} \mathrm{O}$ over $45 \mathrm{~min}$ ). Lyophilization afforded WM6568-b $(6.3 \mathrm{mg}, 4.6 \%)$ as a white powder.

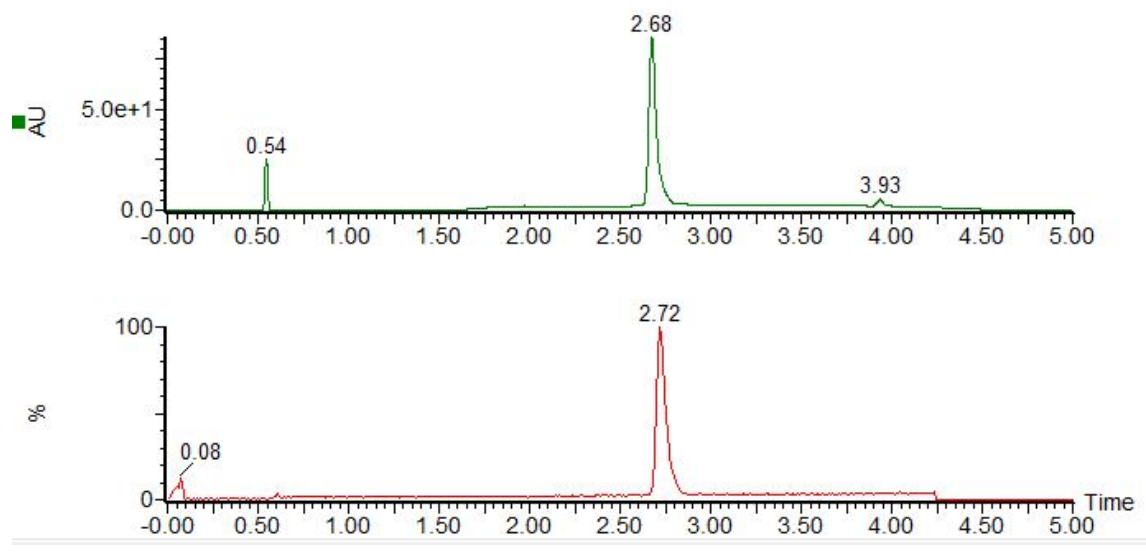

Figure 33. UV (190-400 $\mathrm{nm})$ and MS $(250-3000 \mathrm{~m} / \mathrm{z})$ traces from UPLC-MS analysis of purified WM6568-b (gradient 5-95\% $\mathrm{CH}_{3} \mathrm{CN} / \mathrm{H}_{2} \mathrm{O}$ containing $0.1 \%$ TFA over $5 \mathrm{~min}$ at a flow rate of $0.4 \mathrm{~mL} / \mathrm{min}$ ). 


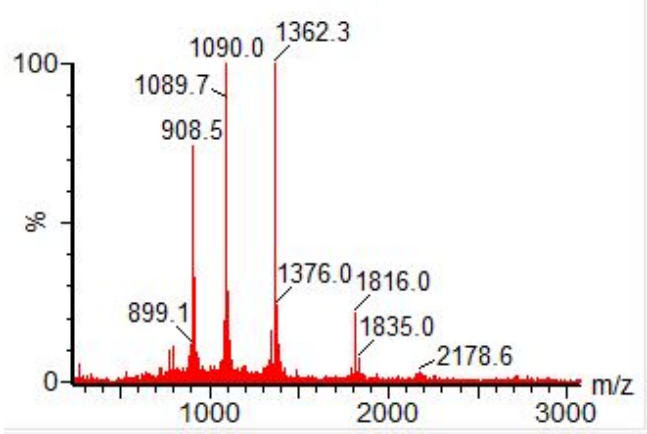

Figure 34. ESI-MS calcd. for $\mathrm{C}_{234} \mathrm{H}_{362} \mathrm{~N}_{58} \mathrm{O}_{91},[\mathrm{M}+3 \mathrm{H}]^{3+} \mathrm{m} / z=1815.6$, found 1816.0; $[\mathrm{M}+4 \mathrm{H}]^{4+} \mathrm{m} / z=$ 1362.0, found 1362.3; $[\mathrm{M}+5 \mathrm{H}]^{5+} \mathrm{m} / \mathrm{z}=1089.8$, found 1090.0; $[\mathrm{M}+6 \mathrm{H}]^{6+} \mathrm{m} / z=908.3$, found 908.5 .

\subsection{Preparation of WM6568}

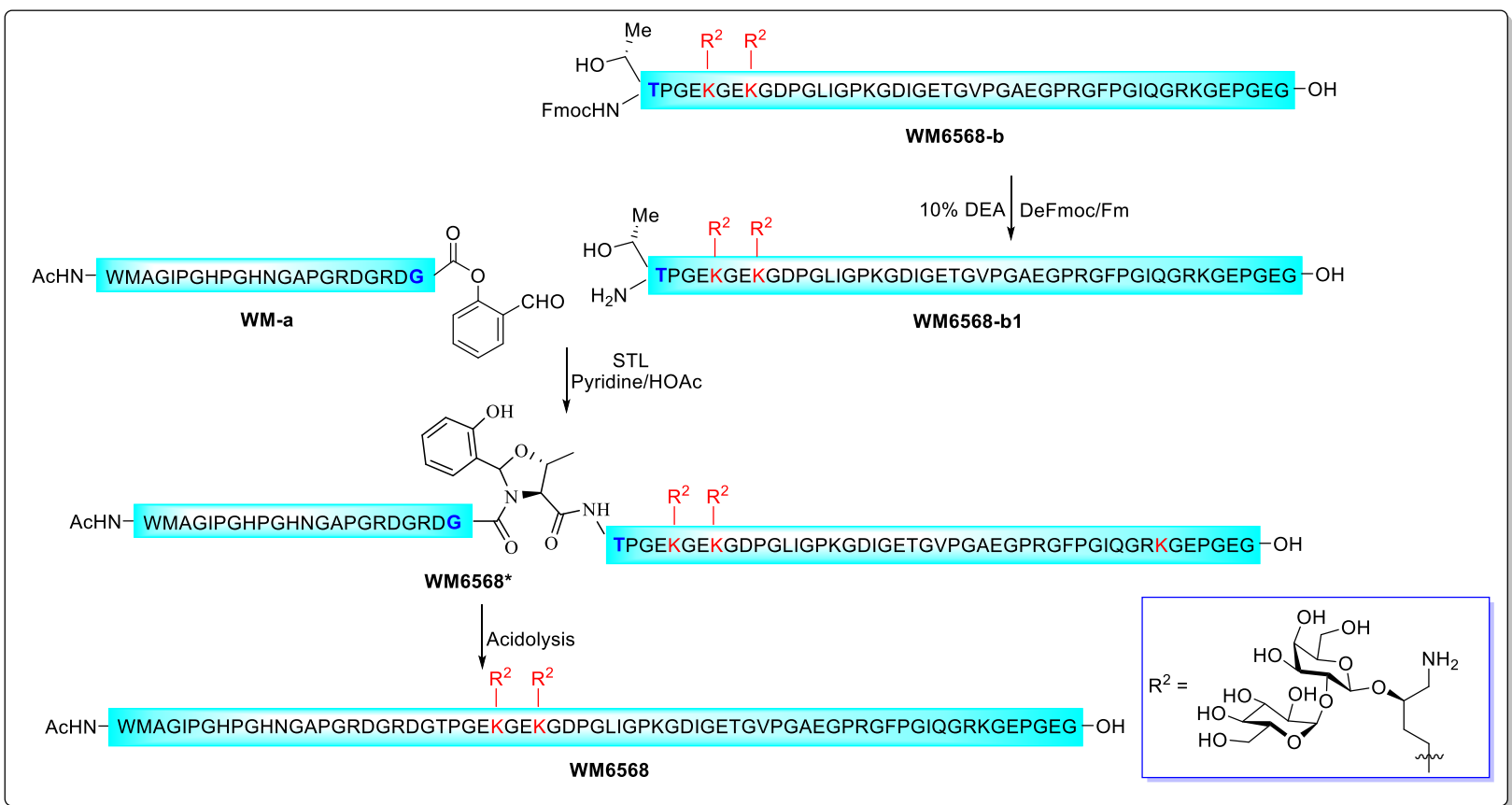

WM6568-b (6.3 mg, $1.16 \mu \mathrm{mol})$ was dissolved in $250 \mu \mathrm{L} \mathrm{CH}_{3} \mathrm{CN} / \mathrm{H}_{2} \mathrm{O} /$ diethylamine $(4.5 / 4.5 / 1$, v/v/v) at room temperature and stirred at room temperature for $2 \mathrm{~h}$ to give product WM6568-b1. The reaction mixture was diluted with $50 \% \mathrm{CH}_{3} \mathrm{CN} / \mathrm{H}_{2} \mathrm{O}(20 \mathrm{~mL})$ and subjected to lyophilization to afford WM6568- 
b1 as a slightly yellow solid. This crude peptide was washed by diethyl ether. After that, WM6568-b1 and WM-a $(2.7 \mathrm{mg}, 1.16 \mu \mathrm{mol})$ were dissolved in pyridine/acetic acid (1/1, mole/mole) buffer at a concentration of $15 \mathrm{mM}$ at room temperature. The reaction mixture was stirred at room temperature for 4 $\mathrm{h}$ to give ligation intermediate $\mathbf{W M 6 5 6 8}$, and the solvent was then blown off under a stream of condensed $\mathrm{N}_{2}$. The residue was treated with $1 \mathrm{~mL}$ TFA/ $\mathrm{H}_{2} \mathrm{O}(95 / 5, \mathrm{v} / \mathrm{v})$ for 20 min to obtain crude product WM6568, and the TFA was blown off under a stream of condensed $\mathrm{N}_{2}$. The remaining residue was subjected to preparative HPLC purification $\left(10-35 \% \mathrm{CH}_{3} \mathrm{CN} / \mathrm{H}_{2} \mathrm{O}\right.$ over $\left.45 \mathrm{~min}\right)$ and lyophilization to afford WM6568 (2.1 mg, 24.3\%) as a white powder.
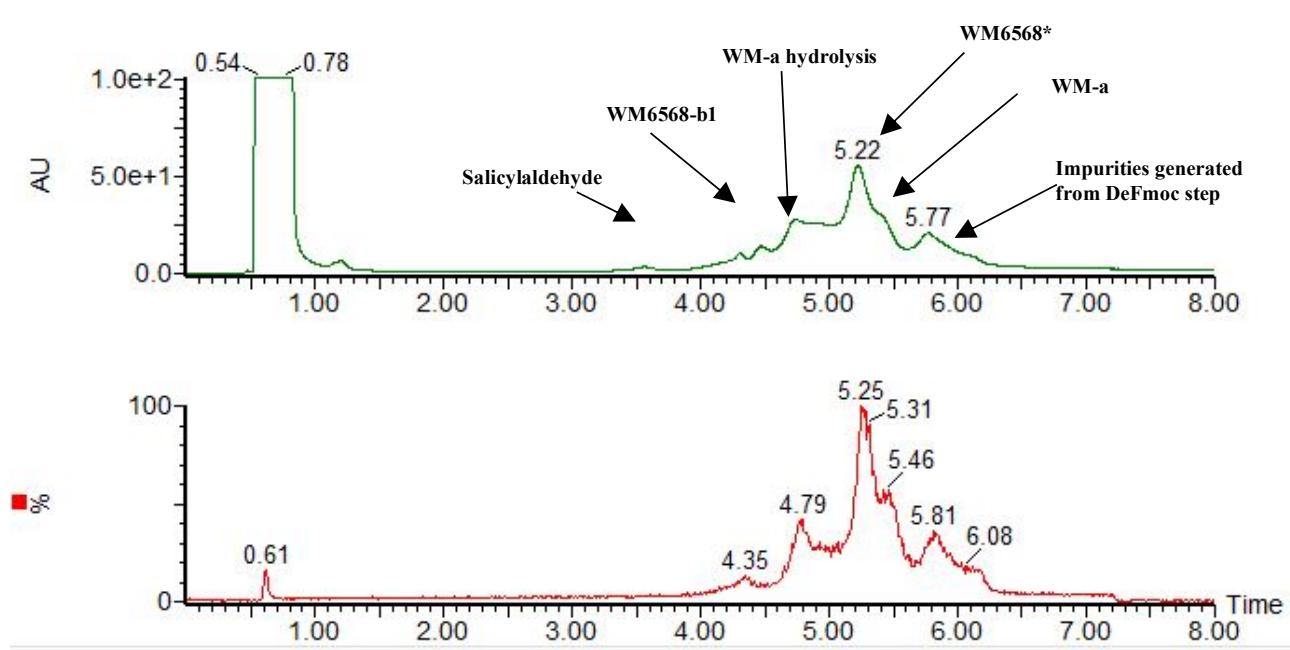

Figure 35. UV (190-400 nm) and MS (250-3000 m/z) traces from UPLC-MS analysis of STL between WM6568-b1 and WM-a at $4 \mathrm{~h}$ (gradient $10-50 \% \mathrm{CH}_{3} \mathrm{CN} / \mathrm{H}_{2} \mathrm{O}$ containing $0.1 \%$ TFA over 8 min at a flow rate of $0.4 \mathrm{~mL} / \mathrm{min}$ ). 


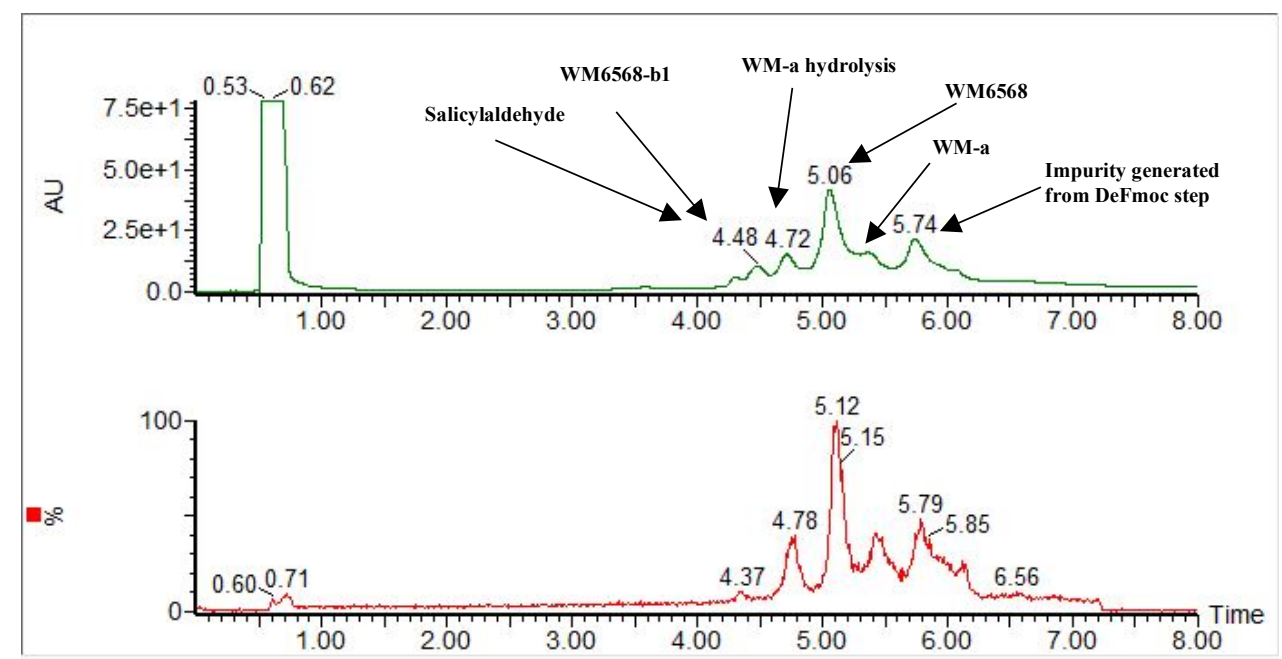

Figure 36. UV (190-400 nm) and MS (250-3000 m/z) traces from UPLC-MS analysis of STL acidolysis between WM6568-b1 and WM-a at $4 \mathrm{~h}$ (gradient $10-50 \% \mathrm{CH}_{3} \mathrm{CN} / \mathrm{H}_{2} \mathrm{O}$ containing $0.1 \%$ TFA over 8 min at a flow rate of $0.4 \mathrm{~mL} / \mathrm{min})$.

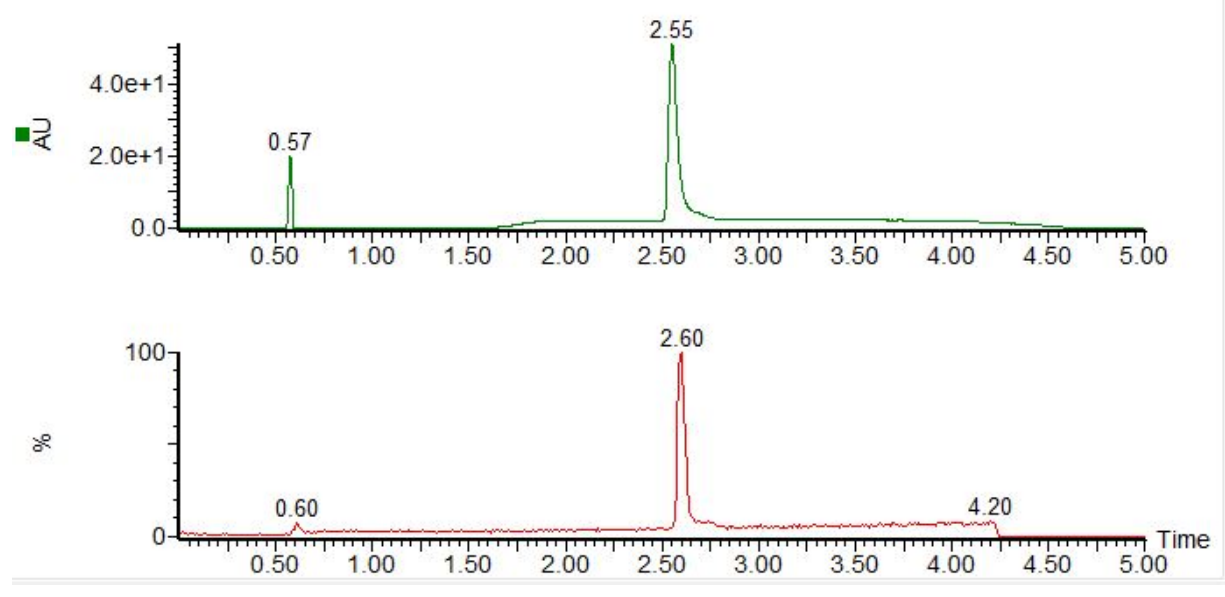

Figure 37. UV (190-400 nm) and MS (250-3000 m/z) traces from UPLC-MS analysis of purified WM6568 (gradient 5-95\% $\mathrm{CH}_{3} \mathrm{CN} / \mathrm{H}_{2} \mathrm{O}$ containing $0.1 \%$ TFA over $5 \mathrm{~min}$ at a flow rate of $0.4 \mathrm{~mL} / \mathrm{min}$ ). 


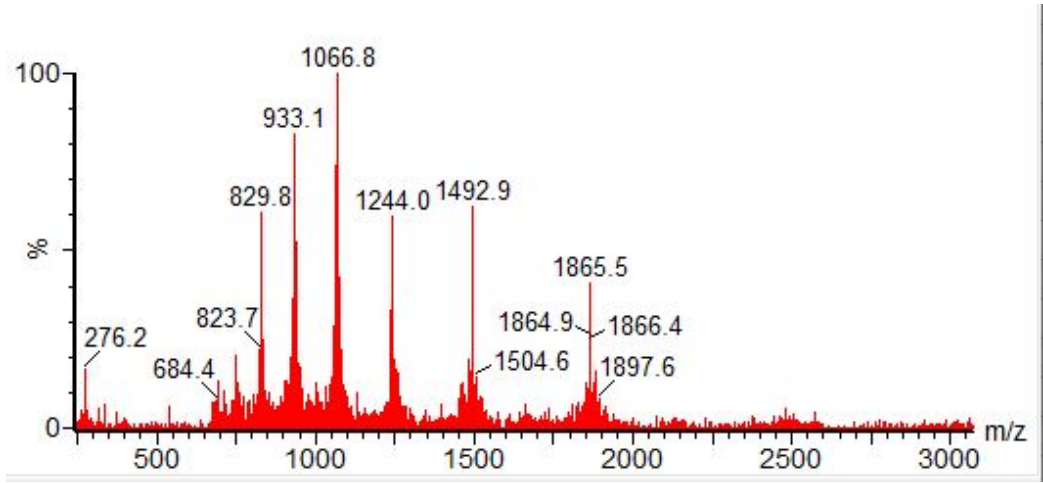

Figure 38. ESI-MS calcd. for $\mathrm{C}_{314} \mathrm{H}_{490} \mathrm{~N}_{92} \mathrm{O}_{117} \mathrm{~S}$, $[\mathrm{M}+4 \mathrm{H}]^{4+} \mathrm{m} / z=1865.5$, found $1865.5 ;[\mathrm{M}+5 \mathrm{H}]^{5+} m / z=$ 1492.6, found 1492.9; $[\mathrm{M}+6 \mathrm{H}]^{6+} m / z=1244.0$, found 1244.0; $[\mathrm{M}+7 \mathrm{H}]^{7+} \mathrm{m} / z=1066.4$, found 1066.8; $[\mathrm{M}+8 \mathrm{H}]^{8+} m / z=933.3$, found 933.1; $[\mathrm{M}+9 \mathrm{H}]^{9+} m / z=829.7$, found 829.8 .

\section{Synthesis of peptide WM-6577}

\subsection{Preparation of WM6577b}

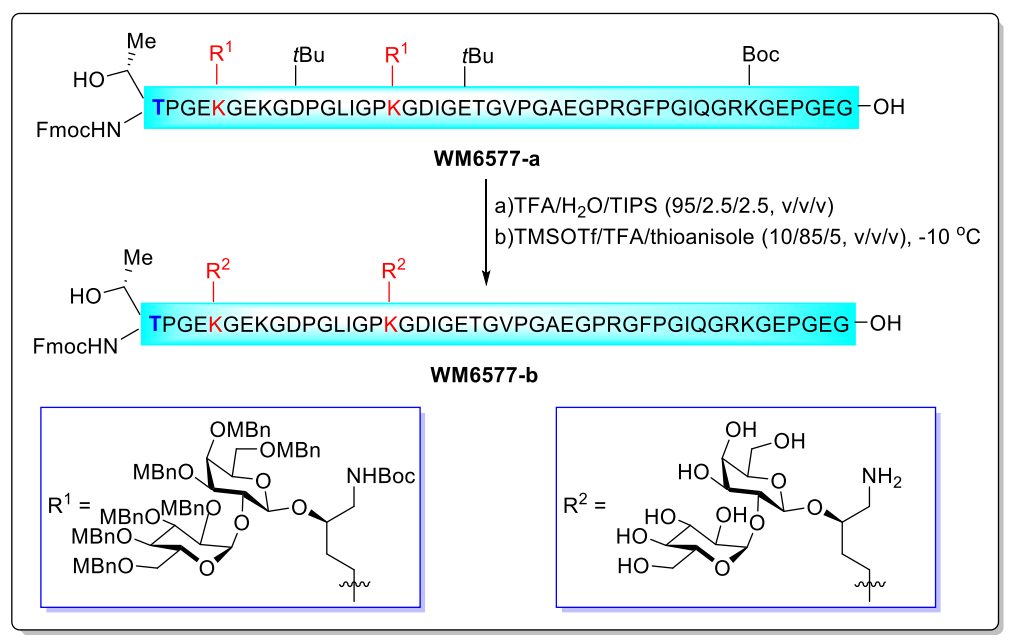

Peptide WM6577-a was synthesized according to the general procedure A using 2-chlorotrityl chloride resin $(50 \mathrm{mg})$ by introducing the glycosylated 5-hydroxylysine building-block at desired positions. Upon completion of synthesis, the crude peptide was then deprotected and cleaved from the resin using $5 \mathrm{~mL}$ 
TFA/TIPS/ $\mathrm{H}_{2} \mathrm{O}(90: 5: 5, \mathrm{v} / \mathrm{v} / \mathrm{v})$ for $1 \mathrm{~h}$. The resin was filtered and the combined filtrate was stirred at -10 ${ }^{\circ} \mathrm{C}$ in cooling bath for $10 \mathrm{~min}$. Then, thioanisole $625 \mu \mathrm{L}$ was added to the above solution and stirred for an additional $10 \mathrm{~min}$. TMSOTf $625 \mu \mathrm{L}$ was slowly added to the above solution and stirred at $-10{ }^{\circ} \mathrm{C}$ for 45 min. The reaction solution was poured into cold $\left(-20{ }^{\circ} \mathrm{C}\right)$ diethyl ether $(45 \mathrm{~mL})$, and the resulting suspension was centrifuged to give a white pellet. After decanting diethyl ether, the remaining solid was dissolved in $2 \mathrm{~mL} 50 \% \mathrm{CH}_{3} \mathrm{CN} / \mathrm{H}_{2} \mathrm{O}$ and $\mathrm{NH}_{4} \mathrm{HCO}_{3}$ solid was added until the solution $\mathrm{pH}$ became 7 . The resulting solution was stirred at room temperature for $1 \mathrm{~h}$ and subjected to preparative HPLC purification (20-50\% $\mathrm{CH}_{3} \mathrm{CN} / \mathrm{H}_{2} \mathrm{O}$ over $\left.45 \mathrm{~min}\right)$. Lyophilization afforded WM6577-b (14.2 $\mathrm{mg}, 10.4 \%$ ) as a white powder.

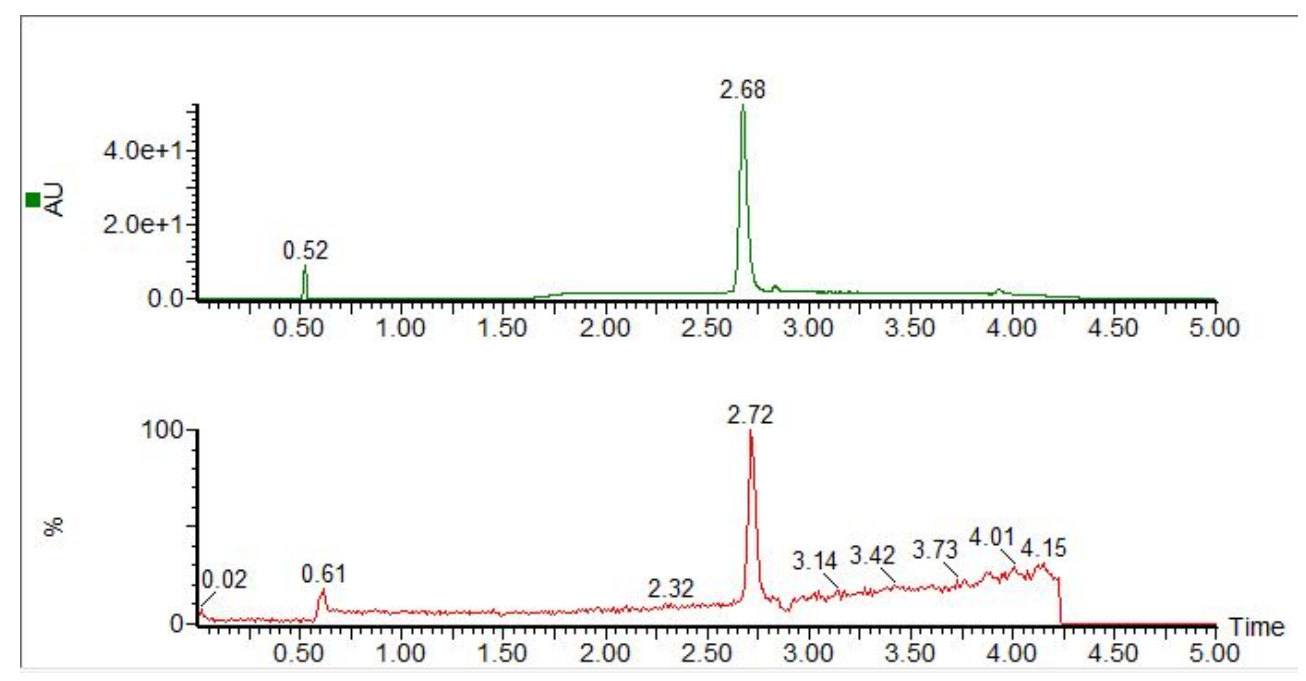

Figure 39. UV (190-400 $\mathrm{nm})$ and MS (250-3000 m/z) traces from UPLC-MS analysis of purified WM6577-b (gradient 5-95\% $\mathrm{CH}_{3} \mathrm{CN} / \mathrm{H}_{2} \mathrm{O}$ containing $0.1 \%$ TFA over $5 \mathrm{~min}$ at a flow rate of $0.4 \mathrm{~mL} / \mathrm{min}$ ). 


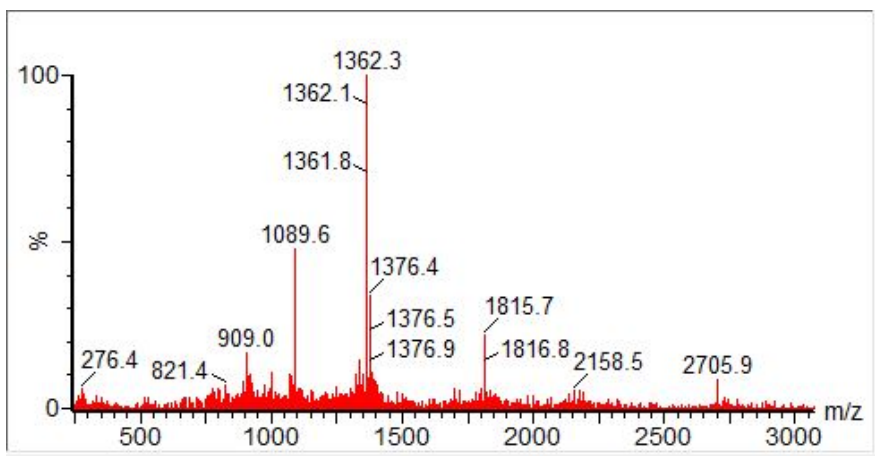

Figure 40. ESI-MS calcd. for $\mathrm{C}_{234} \mathrm{H}_{362} \mathrm{~N}_{58} \mathrm{O}_{91}$, $[\mathrm{M}+3 \mathrm{H}]^{3+} \mathrm{m} / \mathrm{z}=1815.6$, found 1815.7; $[\mathrm{M}+4 \mathrm{H}]^{4+} \mathrm{m} / z=$ 1362.0, found 1362.3; $[\mathrm{M}+5 \mathrm{H}]^{5+} \mathrm{m} / z=1089.8$, found 1089.6.

\subsection{Preparation of WM6577}

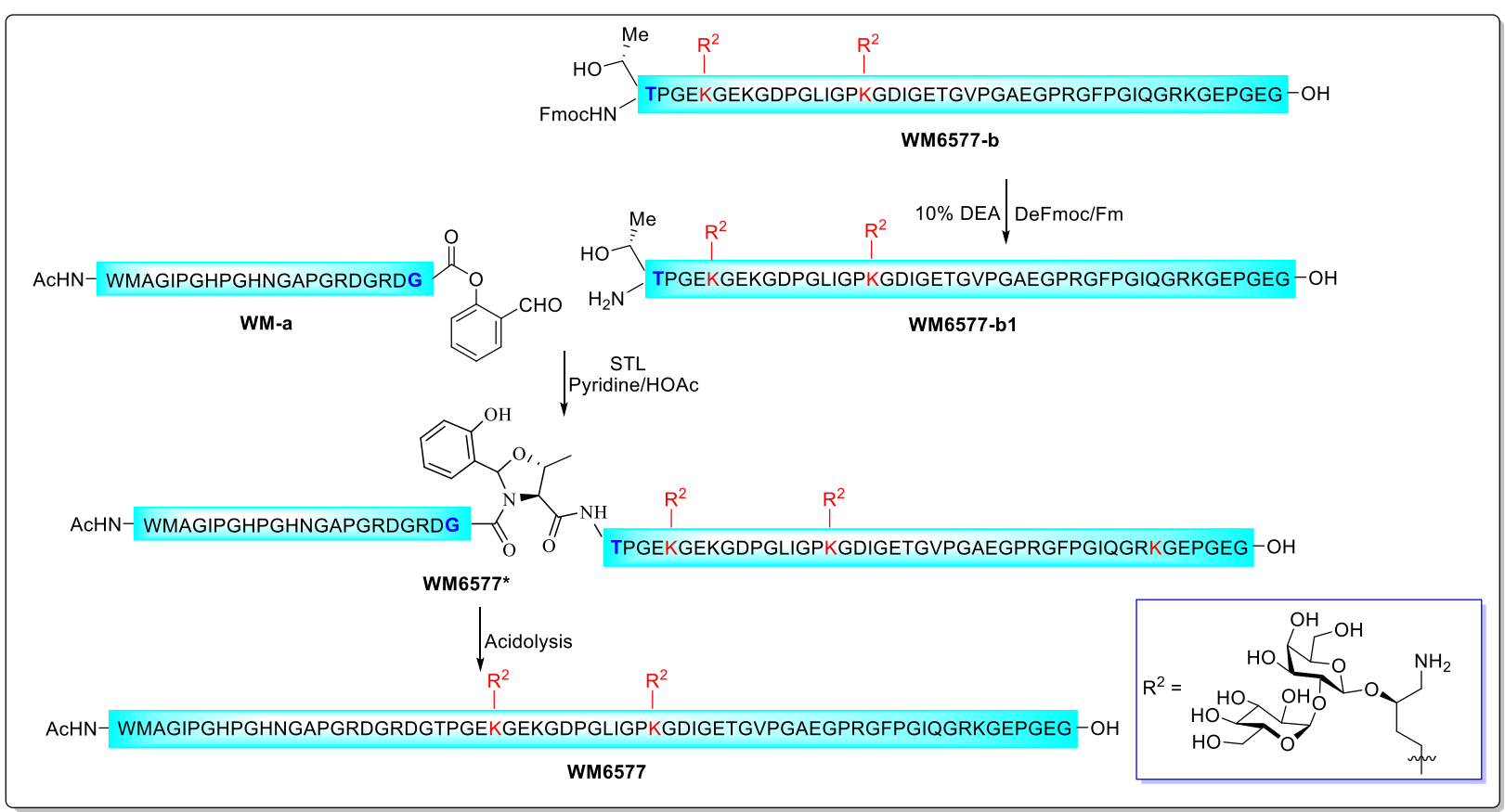

WM6577-b (14.2 mg, $2.61 \mu \mathrm{mol})$ was dissolved in $250 \mu \mathrm{L} \mathrm{CH}_{3} \mathrm{CN} / \mathrm{H}_{2} \mathrm{O} /$ diethylamine $(4.5 / 4.5 / 1$, v/v/v) at room temperature and stirred at room temperature for $2 \mathrm{~h}$ to give product WM6577-b1. The reaction mixture was diluted with $50 \% \mathrm{CH}_{3} \mathrm{CN} / \mathrm{H}_{2} \mathrm{O}(20 \mathrm{~mL})$ and subjected to lyophilization to afford WM6577- 
b1 as a slightly yellow solid. This crude peptide was washed by diethyl ether. After that, WM6577-b1 and WM-a $(6.2 \mathrm{mg}, 2.61 \mu \mathrm{mol})$ were dissolved in pyridine/acetic acid (1/1, mole/mole) buffer at a concentration of $15 \mathrm{mM}$ at room temperature. The reaction mixture was stirred at room temperature for 4 $\mathrm{h}$ to give ligation intermediate $\mathbf{W M 6 5 7 7 ^ { * }}$, and the solvent was then blown off under a stream of condensed $\mathrm{N}_{2}$. The residue was treated with $1 \mathrm{~mL}$ TFA/ $\mathrm{H}_{2} \mathrm{O}(95 / 5, \mathrm{v} / \mathrm{v})$ for 20 min to obtain crude product WM6577, and the TFA was blown off under a stream of condensed $\mathrm{N}_{2}$. The remaining residue was subjected to preparative HPLC purification $\left(10-35 \% \mathrm{CH}_{3} \mathrm{CN} / \mathrm{H}_{2} \mathrm{O}\right.$ over $\left.45 \mathrm{~min}\right)$ and lyophilization to afford WM6577 (6.5 mg, 33.4\%) as a white powder.

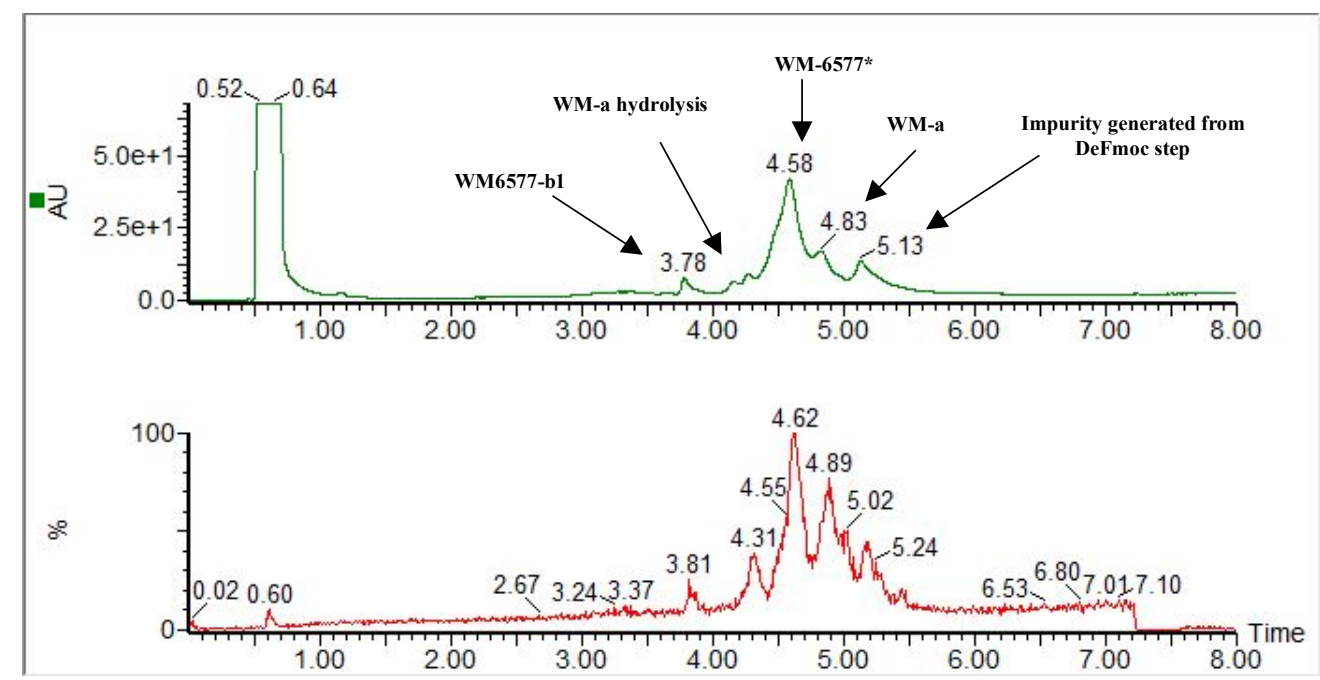

Figure 41. UV (190-400 nm) and MS (250-3000 m/z) traces from UPLC-MS analysis of STL between WM6577-b1 and WM-a at $4 \mathrm{~h}$ (gradient $10-50 \% \mathrm{CH}_{3} \mathrm{CN} / \mathrm{H}_{2} \mathrm{O}$ containing $0.1 \%$ TFA over 8 min at a flow rate of $0.4 \mathrm{~mL} / \mathrm{min}$ ). 


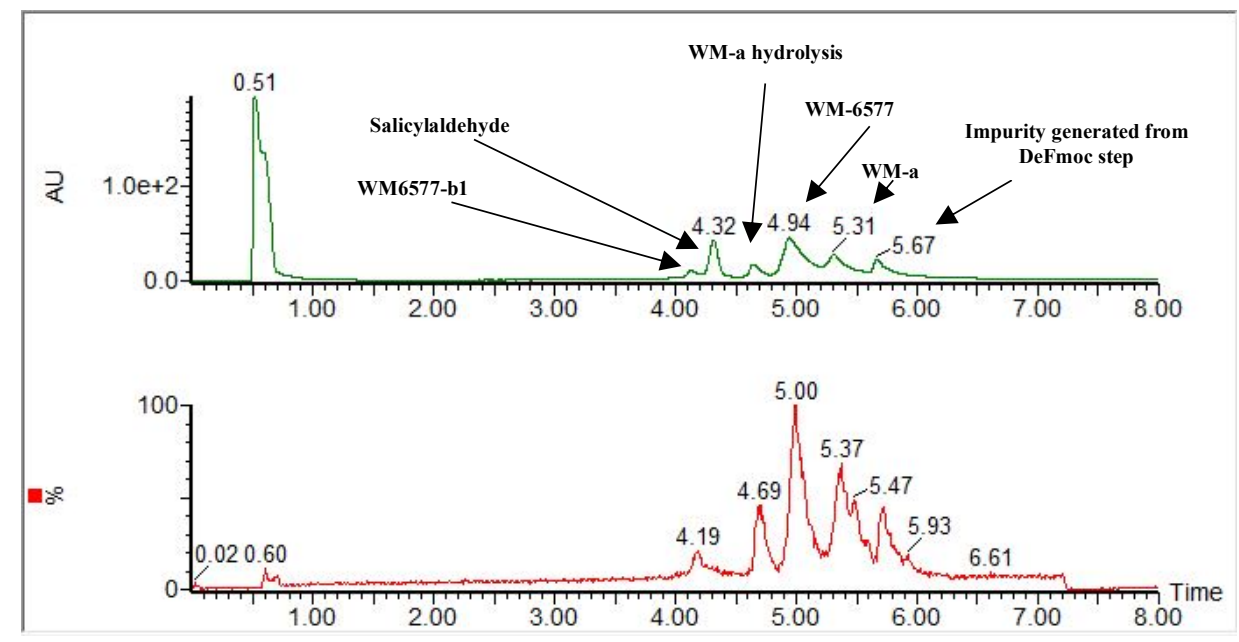

Figure 42. UV (190-400 nm) and MS (250-3000 m/z) traces from UPLC-MS analysis of STL acidolysis between WM6577-b1 and WM-a at $4 \mathrm{~h}$ (gradient $10-35 \% \mathrm{CH}_{3} \mathrm{CN} / \mathrm{H}_{2} \mathrm{O}$ containing $0.1 \%$ TFA over 8 min at a flow rate of $0.4 \mathrm{~mL} / \mathrm{min})$.

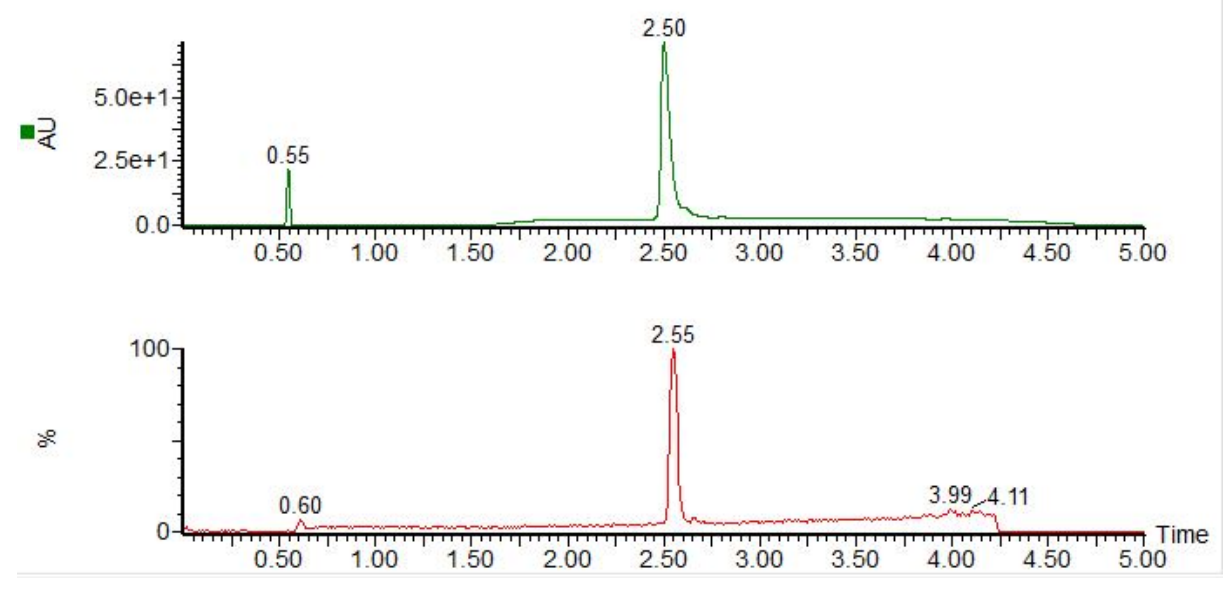

Figure 43. UV (190-400 nm) and MS (250-3000 m/z) traces from UPLC-MS analysis of purified WM6577 (gradient 5-95\% $\mathrm{CH}_{3} \mathrm{CN} / \mathrm{H}_{2} \mathrm{O}$ containing $0.1 \%$ TFA over $5 \mathrm{~min}$ at a flow rate of $0.4 \mathrm{~mL} / \mathrm{min}$ ). 


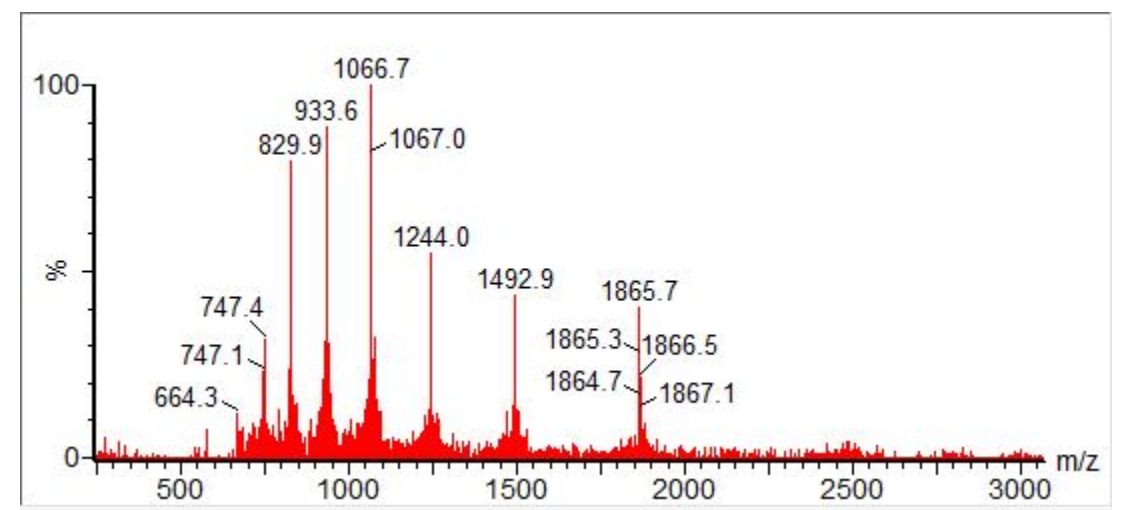

Figure 44. ESI-MS calcd. for $\mathrm{C}_{314} \mathrm{H}_{490} \mathrm{~N}_{92} \mathrm{O}_{117} \mathrm{~S}$, $[\mathrm{M}+4 \mathrm{H}]^{4+} \mathrm{m} / z=1865.5$, found $1865.7 ;[\mathrm{M}+5 \mathrm{H}]^{5+} \mathrm{m} / z=$ 1492.6, found 1492.9; $[\mathrm{M}+6 \mathrm{H}]^{6+} \mathrm{m} / \mathrm{z}=1244.0$, found 1244.0; $[\mathrm{M}+7 \mathrm{H}]^{7+} \mathrm{m} / \mathrm{z}=1066.4$, found 1066.7; $[\mathrm{M}+8 \mathrm{H}]^{8+} \mathrm{m} / z=933.3$, found 933.6; $[\mathrm{M}+9 \mathrm{H}]^{9+} \mathrm{m} / z=829.7$, found $829.9 ;[\mathrm{M}+10 \mathrm{H}]^{10+} \mathrm{m} / z=746.8$, found 747.1.

\section{Synthesis of peptide WM-65101}

\subsection{Preparation of WM65101b}

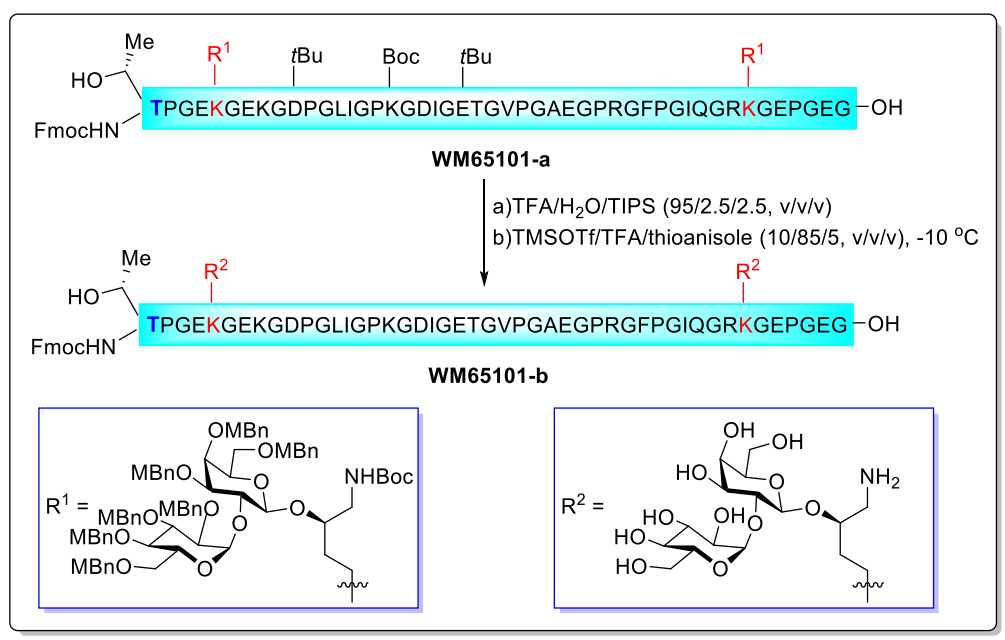

Peptide WM65101-a was synthesized according to the general procedure A using 2-chlorotrityl chloride resin $(50 \mathrm{mg})$ by introducing the glycosylated 5-hydroxylysine building-block at desired positions. Upon completion of synthesis, the crude peptide was then deprotected and cleaved from the resin using $5 \mathrm{~mL}$ 
TFA/TIPS/ $\mathrm{H}_{2} \mathrm{O}(90: 5: 5, \mathrm{v} / \mathrm{v} / \mathrm{v})$ for $1 \mathrm{~h}$. The resin was filtered and the combined filtrate was stirred at -10 ${ }^{\circ} \mathrm{C}$ in cooling bath for $10 \mathrm{~min}$. Then, thioanisole $625 \mu \mathrm{L}$ was added to the above solution and stirred for an additional $10 \mathrm{~min}$. TMSOTf $625 \mu \mathrm{L}$ was slowly added to the above solution and stirred at $-10{ }^{\circ} \mathrm{C}$ for 45 min. The reaction solution was poured into cold $\left(-20{ }^{\circ} \mathrm{C}\right)$ diethyl ether $(45 \mathrm{~mL})$, and the resulting suspension was centrifuged to give a white pellet. After decanting diethyl ether, the remaining solid was dissolved in $2 \mathrm{~mL} 50 \% \mathrm{CH}_{3} \mathrm{CN} / \mathrm{H}_{2} \mathrm{O}$ and $\mathrm{NH}_{4} \mathrm{HCO}_{3}$ solid was added until the solution $\mathrm{pH}$ became 7 . The resulting solution was stirred at room temperature for $1 \mathrm{~h}$ and subjected to preparative HPLC purification (20-50\% $\mathrm{CH}_{3} \mathrm{CN} / \mathrm{H}_{2} \mathrm{O}$ over $\left.45 \mathrm{~min}\right)$. Lyophilization afforded WM65101-b (12.7 $\mathrm{mg}, 9.3 \%$ ) as a white powder.

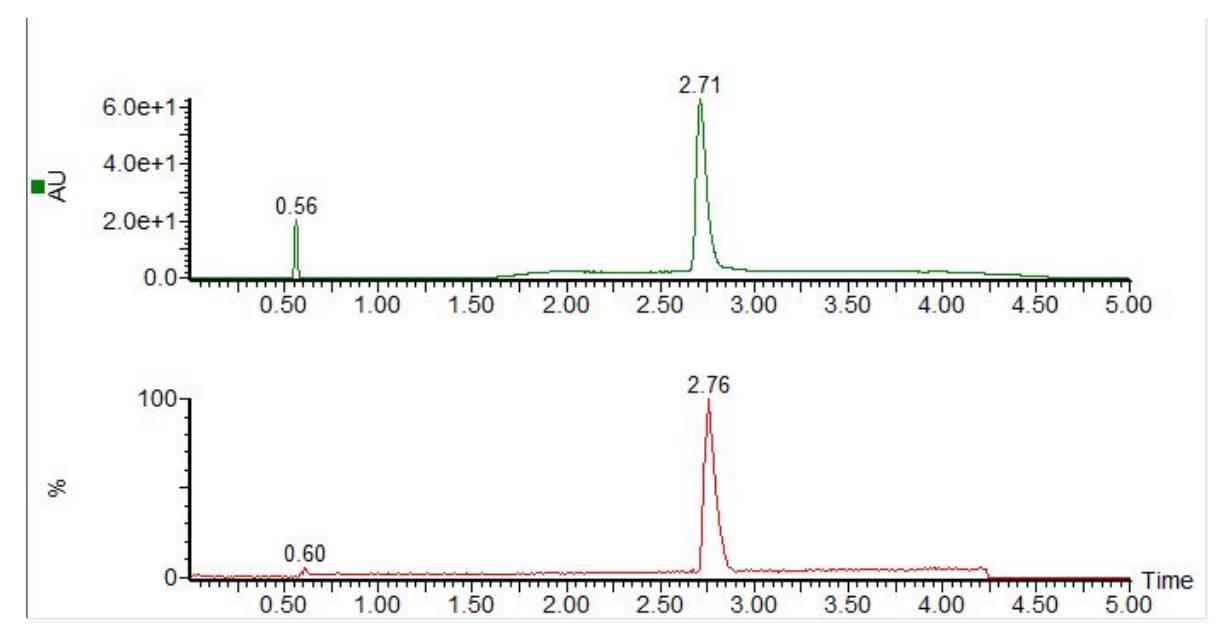

Figure 45. UV (190-400 nm) and MS (250-3000 m/z) traces from UPLC-MS analysis of purified WM65101-b (gradient 5-95\% $\mathrm{CH}_{3} \mathrm{CN} / \mathrm{H}_{2} \mathrm{O}$ containing $0.1 \%$ TFA over $5 \mathrm{~min}$ at a flow rate of 0.4 $\mathrm{mL} / \mathrm{min})$. 


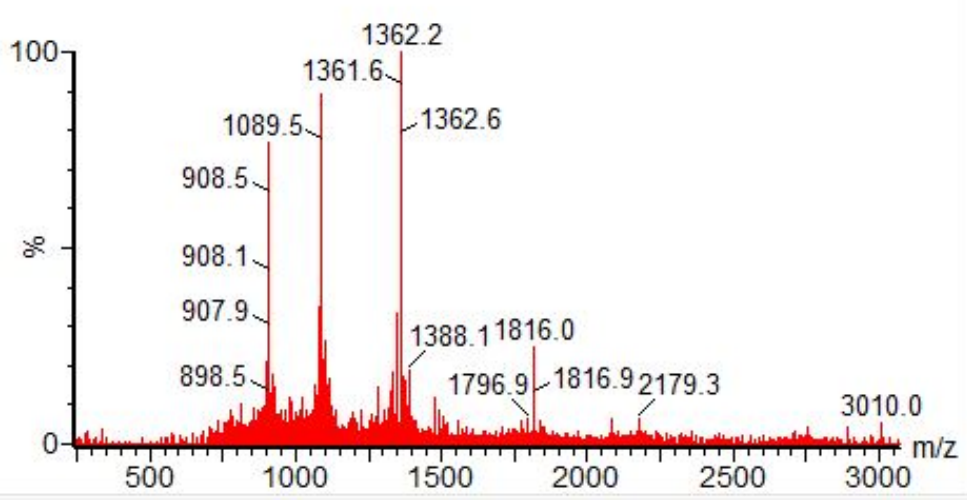

Figure 46. ESI-MS calcd. for $\mathrm{C}_{234} \mathrm{H}_{362} \mathrm{~N}_{58} \mathrm{O}_{91},[\mathrm{M}+3 \mathrm{H}]^{3+} m / z=1815.6$, found 1816.0; $[\mathrm{M}+4 \mathrm{H}]^{4+} m / z=$ 1362.0, found 1362.2; $[\mathrm{M}+5 \mathrm{H}]^{5+} \mathrm{m} / z=1089.8$, found 1089.5; $[\mathrm{M}+6 \mathrm{H}]^{6+} \mathrm{m} / z=908.3$, found 908.5 .

\subsection{Preparation of WM65101}

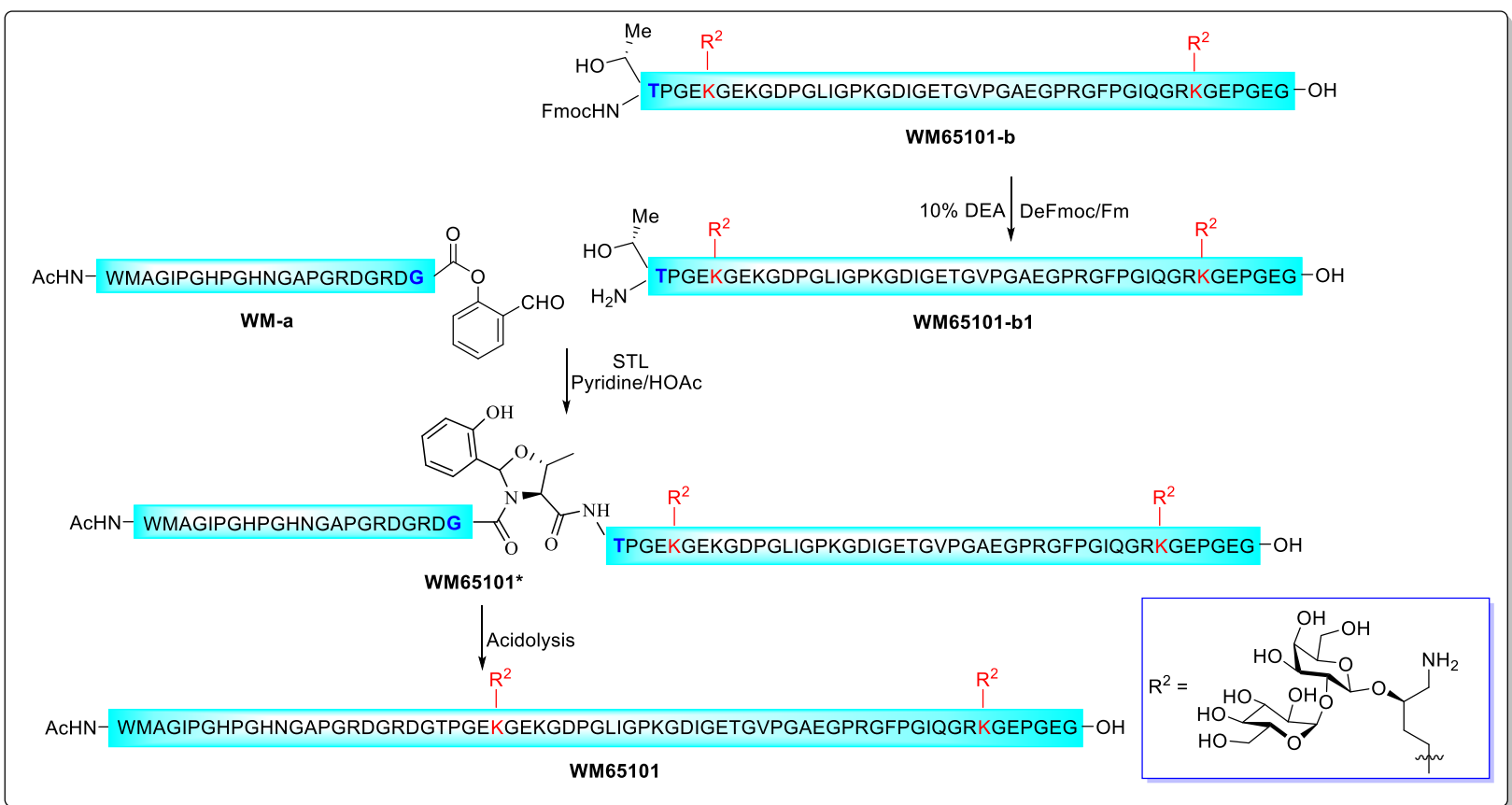

WM65101-b (12.7 mg, $2.33 \mu \mathrm{mol})$ was dissolved in $250 \mu \mathrm{L} \mathrm{CH}_{3} \mathrm{CN} / \mathrm{H}_{2} \mathrm{O} /$ diethylamine $(4.5 / 4.5 / 1$, v/v/v) at room temperature and stirred at room temperature for $2 \mathrm{~h}$ to give product WM65101-b1. The reaction 
mixture was diluted with $50 \% \mathrm{CH}_{3} \mathrm{CN} / \mathrm{H}_{2} \mathrm{O}(20 \mathrm{~mL})$ and subjected to lyophilization to afford WM65101b1 as a slightly yellow solid. This crude peptide was washed by diethyl ether. After that, WM65101-b1 and WM-a $(5.5 \mathrm{mg}, 2.33 \mu \mathrm{mol})$ were dissolved in pyridine/acetic acid (1/1, mole/mole) buffer at a concentration of $15 \mathrm{mM}$ at room temperature. The reaction mixture was stirred at room temperature for 4 $\mathrm{h}$ to give ligation intermediate WM65101*, and the solvent was then blown off under a stream of condensed $\mathrm{N}_{2}$. The residue was treated with $1 \mathrm{~mL}$ TFA/ $\mathrm{H}_{2} \mathrm{O}(95 / 5, \mathrm{v} / \mathrm{v})$ for $20 \mathrm{~min}$ to obtain crude product WM65101, and the TFA was blown off under a stream of condensed $\mathrm{N}_{2}$. The remaining residue was subjected to preparative HPLC purification $\left(10-35 \% \mathrm{CH}_{3} \mathrm{CN} / \mathrm{H}_{2} \mathrm{O}\right.$ over $\left.45 \mathrm{~min}\right)$ and lyophilization to afford WM65101 (4.0 mg, 23\%) as a white powder.

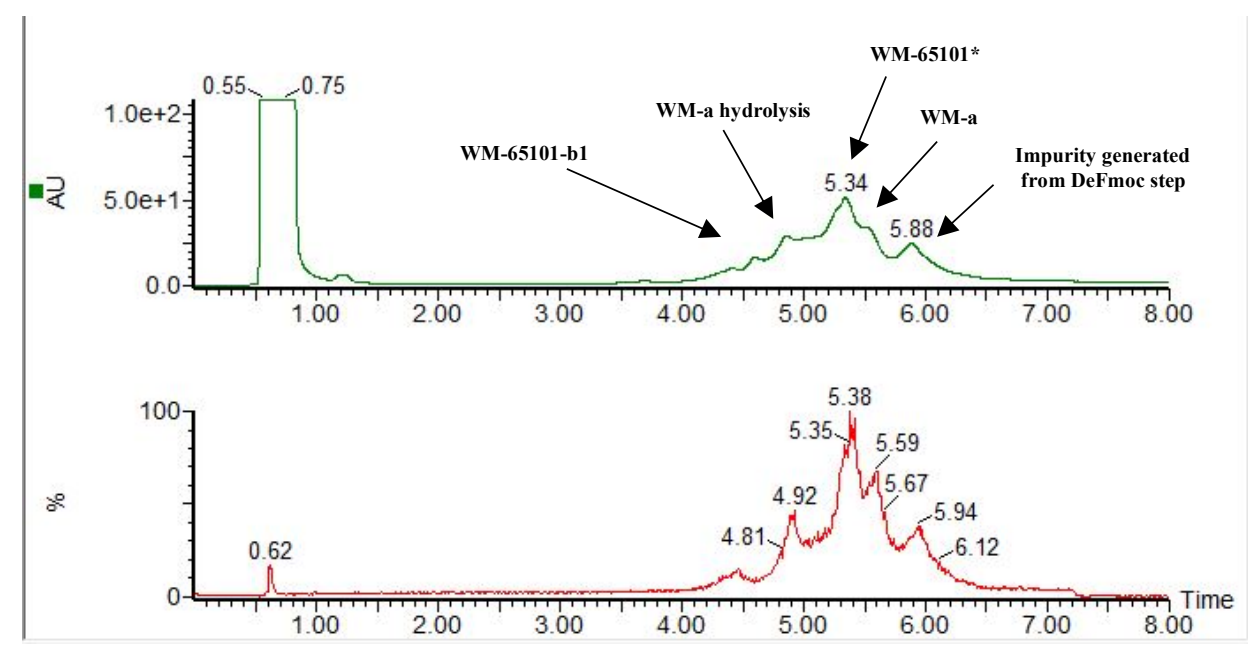

Figure 47. UV (190-400 nm) and MS (250-3000 m/z) traces from UPLC-MS analysis of STL between WM65101-b1 and WM-a at $4 \mathrm{~h}$ (gradient $10-50 \% \mathrm{CH}_{3} \mathrm{CN} / \mathrm{H}_{2} \mathrm{O}$ containing $0.1 \%$ TFA over 8 min at a flow rate of $0.4 \mathrm{~mL} / \mathrm{min})$. 


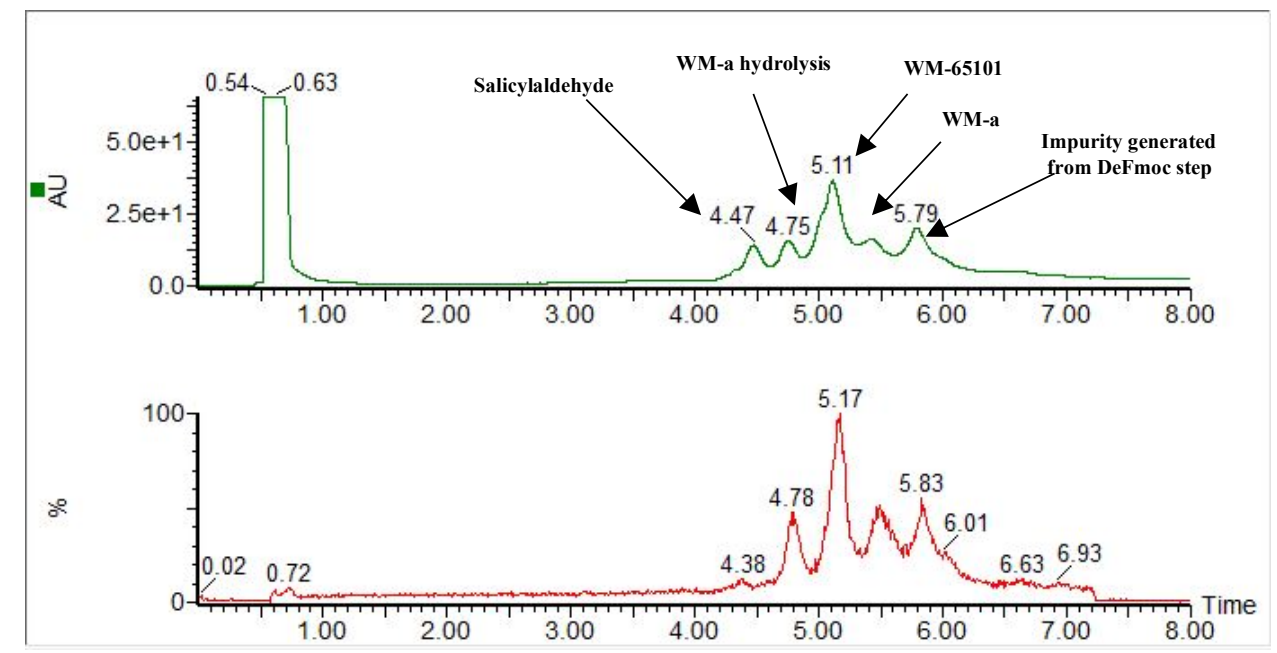

Figure 48. UV (190-400 nm) and MS (250-3000 m/z) traces from UPLC-MS analysis of STL acidolysis between WM65101-b1 and WM-a at $4 \mathrm{~h}$ (gradient $10-35 \% \mathrm{CH}_{3} \mathrm{CN} / \mathrm{H}_{2} \mathrm{O}$ containing $0.1 \%$ TFA over 8 $\min$ at a flow rate of $0.4 \mathrm{~mL} / \mathrm{min}$ ).

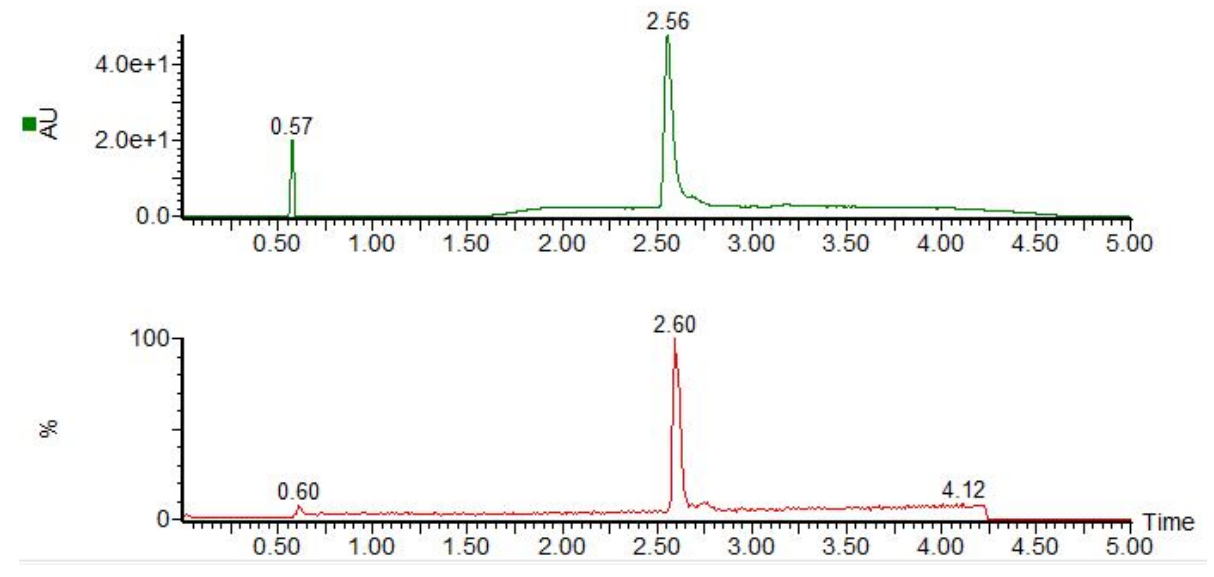

Figure 49. UV (190-400 nm) and MS (250-3000 m/z) traces from UPLC-MS analysis of purified WM65101 (gradient 5-95\% $\mathrm{CH}_{3} \mathrm{CN} / \mathrm{H}_{2} \mathrm{O}$ containing $0.1 \%$ TFA over $5 \mathrm{~min}$ at a flow rate of $0.4 \mathrm{~mL} / \mathrm{min}$ ). 


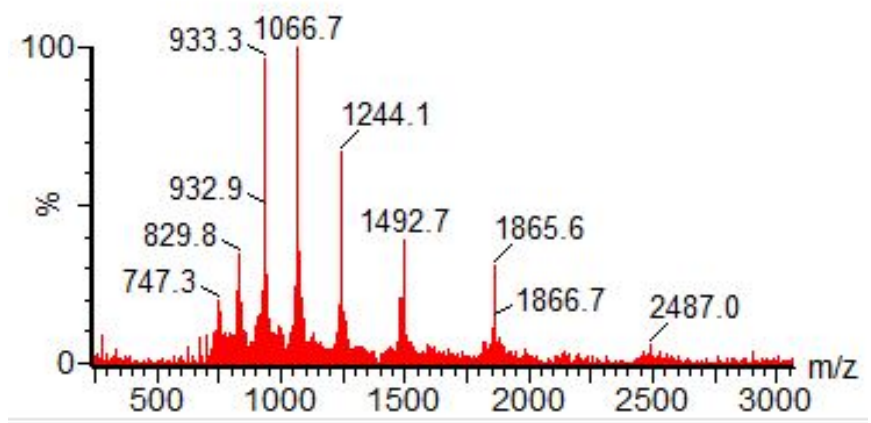

Figure 50. ESI-MS calcd. for $\mathrm{C}_{314} \mathrm{H}_{490} \mathrm{~N}_{92} \mathrm{O}_{117} \mathrm{~S}$, $[\mathrm{M}+3 \mathrm{H}]^{3+} \mathrm{m} / z=2487.0$, found 2487.0; $[\mathrm{M}+4 \mathrm{H}]^{4+} \mathrm{m} / z=$ 1865.5, found 1865.6; $[\mathrm{M}+5 \mathrm{H}]^{5+} \mathrm{m} / z=1492.6$, found 1492.7; $[\mathrm{M}+6 \mathrm{H}]^{6+} \mathrm{m} / z=1244.0$, found 1244.1; $[\mathrm{M}+7 \mathrm{H}]^{7+} m / z=1066.4$, found 1066.7; $[\mathrm{M}+8 \mathrm{H}]^{8+} \mathrm{m} / z=933.3$, found 933.3; $[\mathrm{M}+9 \mathrm{H}]^{9+} \mathrm{m} / \mathrm{z}=829.7$, found 829.8.

\section{Synthesis of peptide WM-6877}

\subsection{Preparation of WM6877b}

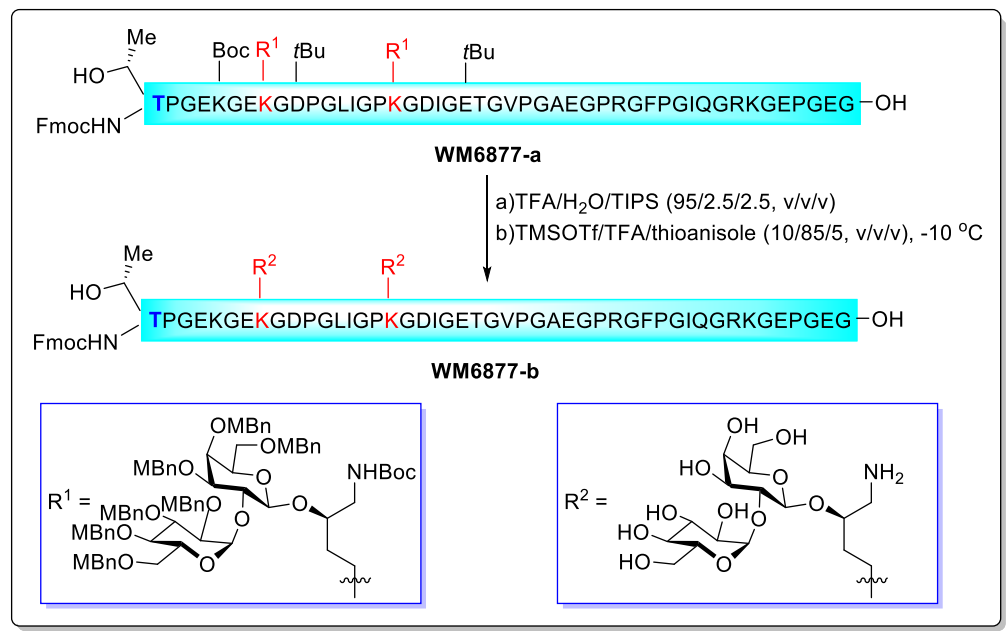

Peptide WM6877-a was synthesized according to the general procedure A using 2-chlorotrityl chloride resin (150 mg) by introducing the glycosylated 5-hydroxylysine building-block at desired positions. Upon 
completion of synthesis, the crude peptide was then deprotected and cleaved from the resin using $15 \mathrm{~mL}$ TFA/TIPS/ $\mathrm{H}_{2} \mathrm{O}(90: 5: 5, \mathrm{v} / \mathrm{v} / \mathrm{v})$ for $1 \mathrm{~h}$. The resin was filtered and the combined filtrate was stirred at -10 ${ }^{\circ} \mathrm{C}$ in cooling bath for $10 \mathrm{~min}$. Then, thioanisole $1.8 \mathrm{~mL}$ was added to the above solution and stirred for an additional $10 \mathrm{~min}$. TMSOTf $1.8 \mathrm{~mL}$ was slowly added to the above solution and stirred at $-10{ }^{\circ} \mathrm{C}$ for 45 min. The reaction solution was poured into cold $\left(-20^{\circ} \mathrm{C}\right)$ diethyl ether $(180 \mathrm{~mL})$, and the resulting suspension was centrifuged to give a white pellet. After decanting diethyl ether, the remaining solid was dissolved in $8 \mathrm{~mL} 50 \% \mathrm{CH}_{3} \mathrm{CN} / \mathrm{H}_{2} \mathrm{O}$ and $\mathrm{NH}_{4} \mathrm{HCO}_{3}$ solid was added until the solution $\mathrm{pH}$ became 7 . The resulting solution was stirred at room temperature for $1 \mathrm{~h}$ and subjected to preparative HPLC purification (20-50\% $\mathrm{CH}_{3} \mathrm{CN} / \mathrm{H}_{2} \mathrm{O}$ over $\left.45 \mathrm{~min}\right)$. Lyophilization afforded WM6877-b (47.3 $\mathrm{mg}, 11.6 \%$ ) as a white powder.

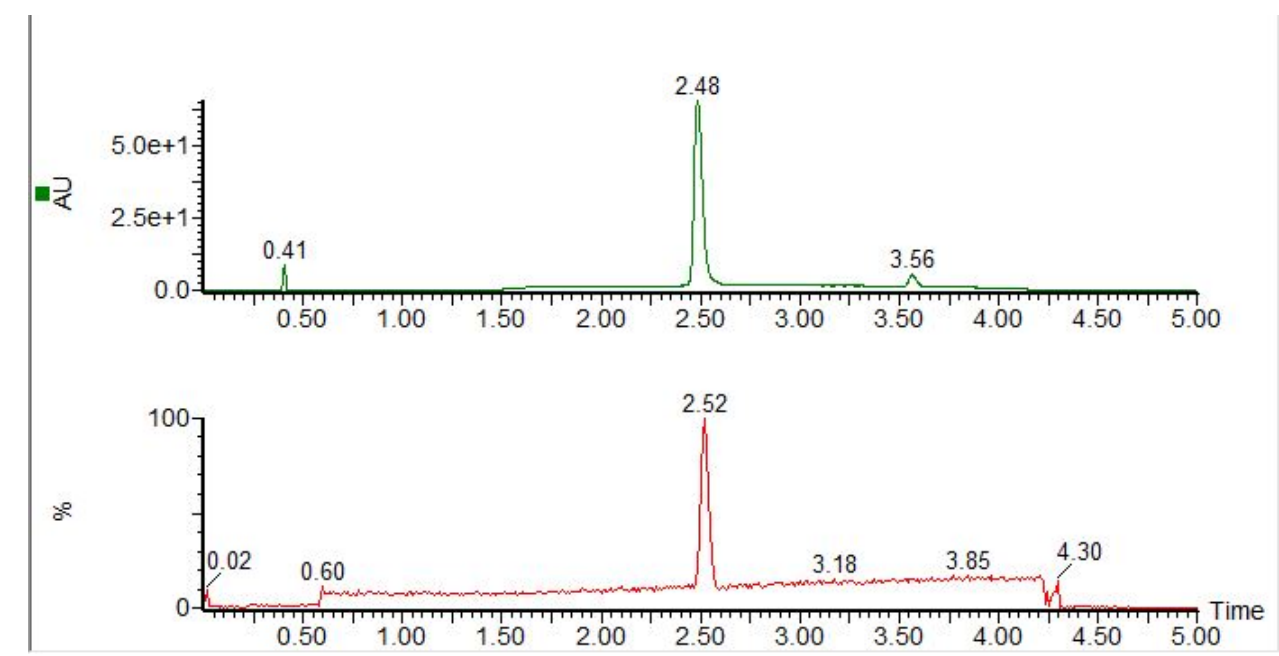

Figure 51. UV (190-400 $\mathrm{nm})$ and MS $(250-3000 \mathrm{~m} / \mathrm{z})$ traces from UPLC-MS analysis of purified WM6877-b (gradient 5-95\% $\mathrm{CH}_{3} \mathrm{CN} / \mathrm{H}_{2} \mathrm{O}$ containing $0.1 \%$ TFA over $5 \mathrm{~min}$ at a flow rate of $0.4 \mathrm{~mL} / \mathrm{min}$ ). 


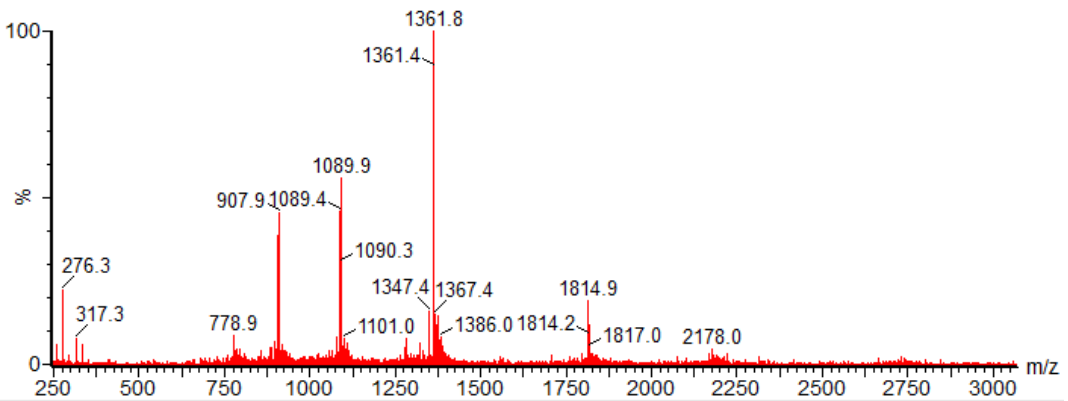

Figure 52. ESI-MS calcd. for $\mathrm{C}_{234} \mathrm{H}_{362} \mathrm{~N}_{58} \mathrm{O}_{91}$, $[\mathrm{M}+3 \mathrm{H}]^{3+} m / z=1815.6$, found 1814.9; $[\mathrm{M}+4 \mathrm{H}]^{4+} m / z=$ 1362.0, found 1361.8; $[\mathrm{M}+5 \mathrm{H}]^{5+} m / z=1089.8$, found 1089.9; $[\mathrm{M}+6 \mathrm{H}]^{6+} m / z=908.3$, found 907.9; $[\mathrm{M}+7 \mathrm{H}]^{7+} m / z=778.7$, found 778.9 .

\subsection{Preparation of WM6877}

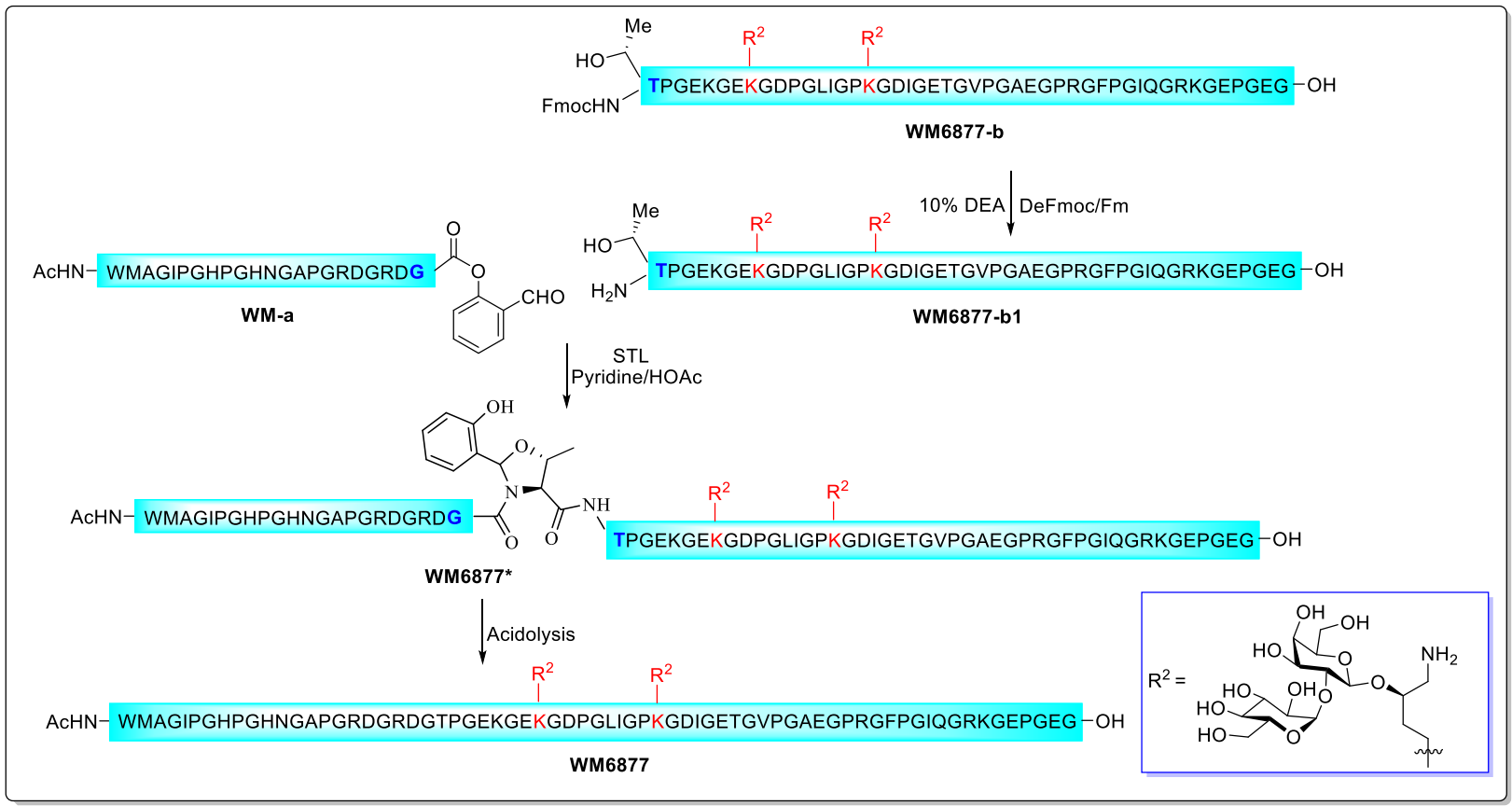

WM6877-b (47.3 mg, $8.67 \mu \mathrm{mol})$ was dissolved in $500 \mu \mathrm{L} \mathrm{CH}_{3} \mathrm{CN} / \mathrm{H}_{2} \mathrm{O} /$ diethylamine $(4.5 / 4.5 / 1$, v/v/v) at room temperature and was stirred at room temperature for $2 \mathrm{~h}$ to give product WM6877-b1. The reaction 
mixture was diluted with $50 \% \mathrm{CH}_{3} \mathrm{CN} / \mathrm{H}_{2} \mathrm{O}(20 \mathrm{~mL})$, and then followed by concentration under reduced pressure and lyophilization to afford WM6877-b1 as slightly yellow solid. After that, WM6877-b1 and WM-a $(20.4 \mathrm{mg}, 8.67 \mu \mathrm{mol})$ were dissolved in pyridine/acetic acid $(1 / 1$, mole/mole $)$ buffer at a concentration of $15 \mathrm{mM}$ at room temperature. The reaction mixture was stirred at room temperature for 4 $\mathrm{h}$ to give ligation intermediate $\mathbf{W M 6 8 7 7}^{*}$, and the solvent was then blown off under a stream of condensed $\mathrm{N}_{2}$. The residue was treated with $1.5 \mathrm{~mL} \mathrm{TFA} / \mathrm{H}_{2} \mathrm{O}(95 / 5, \mathrm{v} / \mathrm{v})$ for $10 \mathrm{~min}$ to obtain crude product WM6877, and the volatile species were blown off under a stream of condensed $\mathrm{N}_{2}$. After that, the remaining residue was subjected to preparative HPLC purification $\left(10-35 \% \mathrm{CH}_{3} \mathrm{CN} / \mathrm{H}_{2} \mathrm{O}\right.$ over $\left.45 \min \right)$ and followed by concentration under reduced pressure and lyophilization to afford WM6877 (24.5 mg, $37.8 \%$ ) as a white powder.

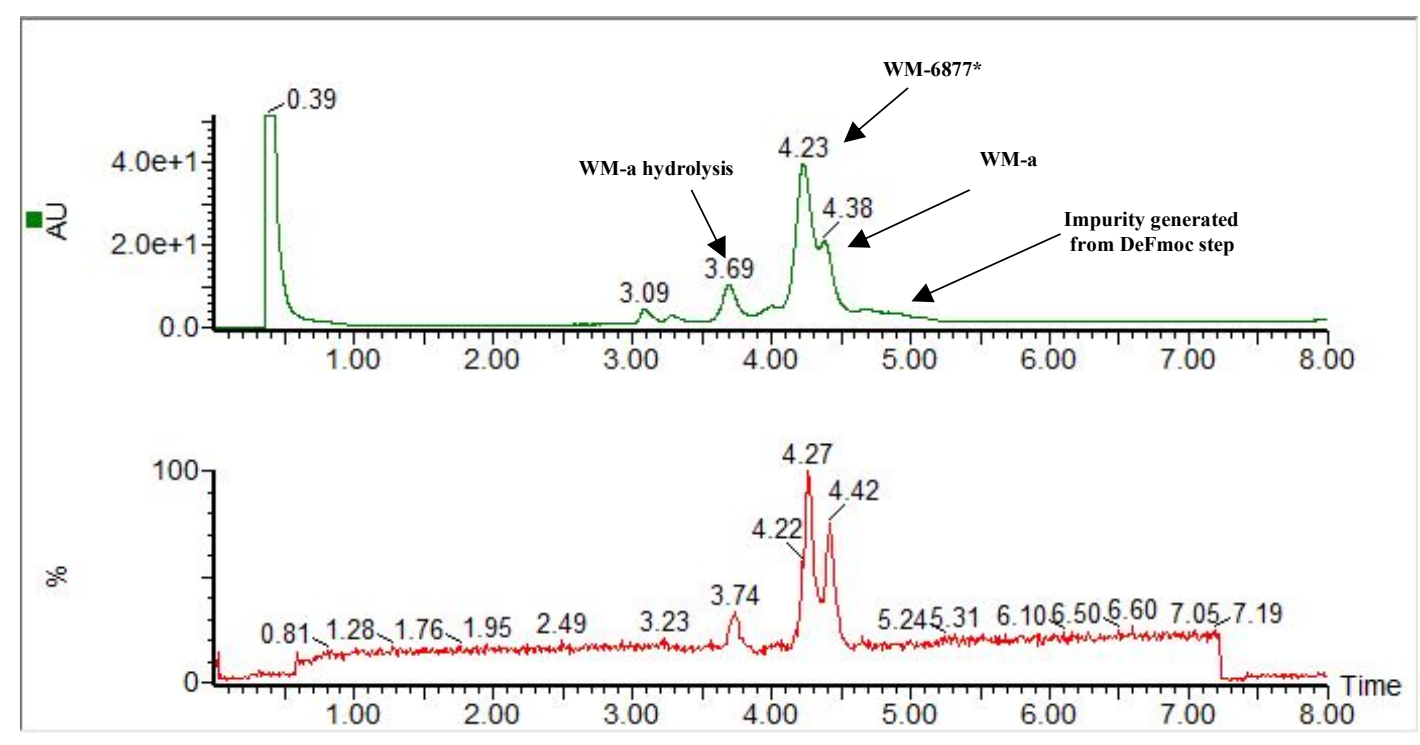

Figure 53. UV (190-400 nm) and MS (250-3000 m/z) traces from UPLC-MS analysis of STL between WM6877-b1 and WM-a at $4 \mathrm{~h}$ (gradient $10-50 \% \mathrm{CH}_{3} \mathrm{CN} / \mathrm{H}_{2} \mathrm{O}$ containing $0.1 \%$ TFA over 8 min at a flow rate of $0.4 \mathrm{~mL} / \mathrm{min}$ ). 


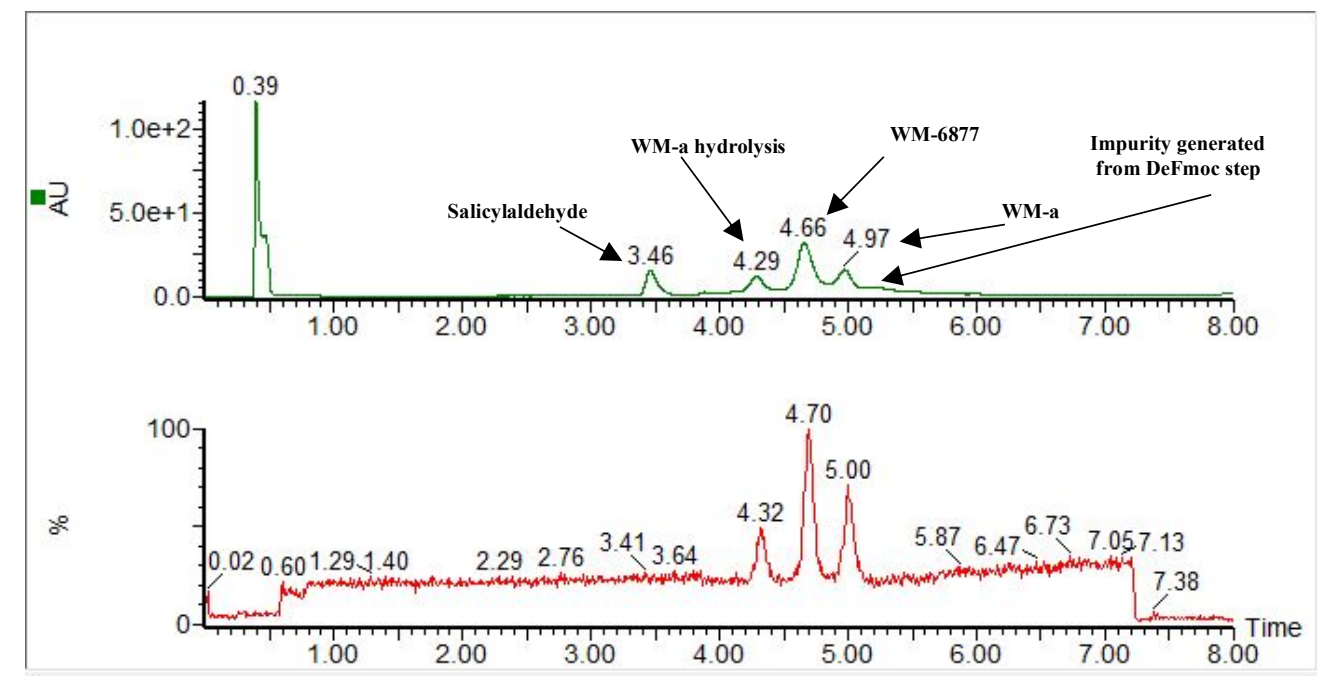

Figure 54. UV (190-400 nm) and MS (250-3000 m/z) traces from UPLC-MS analysis of STL acidolysis between WM6877-b1 and WM-a at $4 \mathrm{~h}$ (gradient $10-35 \% \mathrm{CH}_{3} \mathrm{CN} / \mathrm{H}_{2} \mathrm{O}$ containing $0.1 \%$ TFA over 8 min at a flow rate of $0.4 \mathrm{~mL} / \mathrm{min})$.

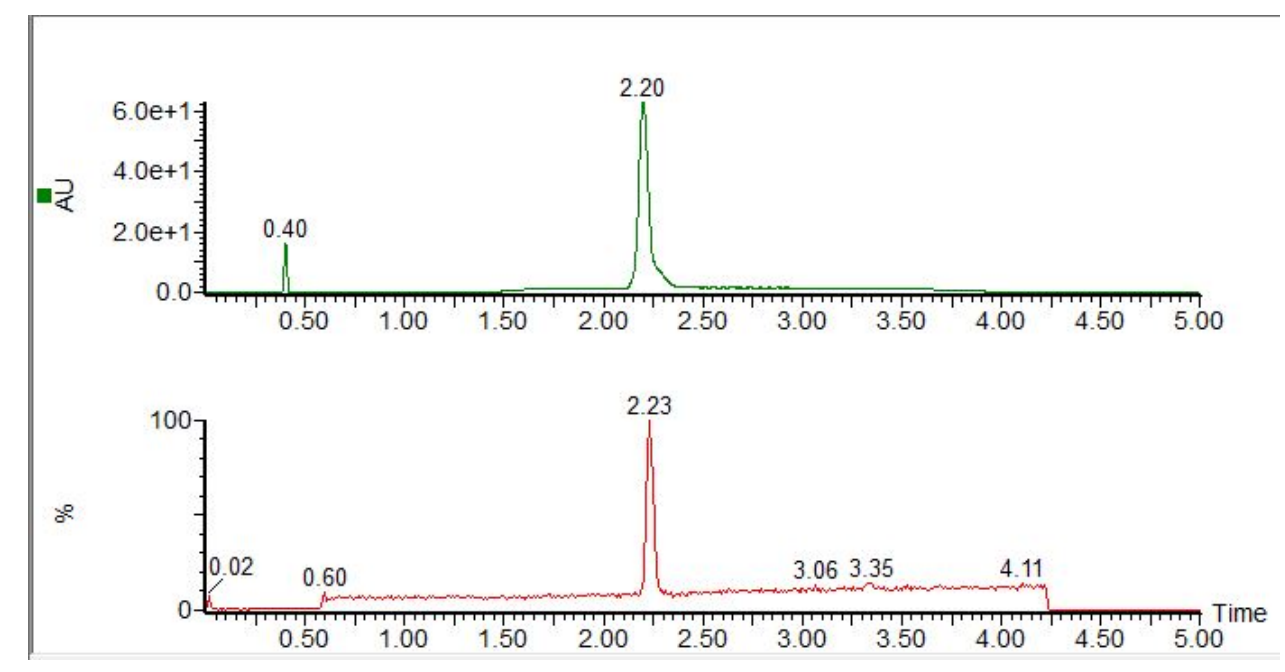

Figure 55. UV (190-400 nm) and MS (250-3000 m/z) traces from UPLC-MS analysis of purified WM6877 (gradient 5-95\% $\mathrm{CH}_{3} \mathrm{CN} / \mathrm{H}_{2} \mathrm{O}$ containing $0.1 \%$ TFA over $5 \mathrm{~min}$ at a flow rate of $0.4 \mathrm{~mL} / \mathrm{min}$ ). 


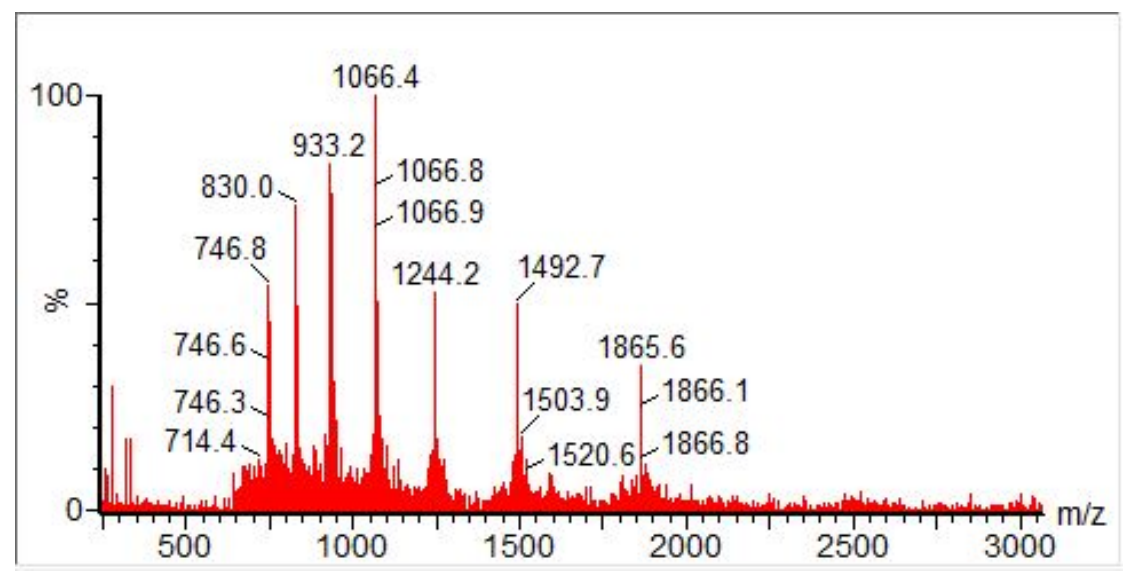

Figure 56. ESI-MS calcd. for $\mathrm{C}_{314} \mathrm{H}_{490} \mathrm{~N}_{92} \mathrm{O}_{117} \mathrm{~S},[\mathrm{M}+4 \mathrm{H}]^{4+} \mathrm{m} / z=1865.5$, found 1865.6; $[\mathrm{M}+5 \mathrm{H}]^{5+} \mathrm{m} / z$ $=1492.6$, found 1492.7; $[\mathrm{M}+6 \mathrm{H}]^{6+} m / z=1244.0$, found 1244.2; $[\mathrm{M}+7 \mathrm{H}]^{7+} \mathrm{m} / z=1066.4$, found 1064; $[\mathrm{M}+8 \mathrm{H}]^{8+} \mathrm{m} / \mathrm{z}=933.3$, found 933.2; $[\mathrm{M}+9 \mathrm{H}]^{9+} \mathrm{m} / \mathrm{z}=829.7$, found $830.0 ;[\mathrm{M}+10 \mathrm{H}]^{10+} \mathrm{m} / \mathrm{z}=746.8$, found 746.8

\section{Synthesis of peptide WM-68101}

\subsection{Preparation of WM68101a}

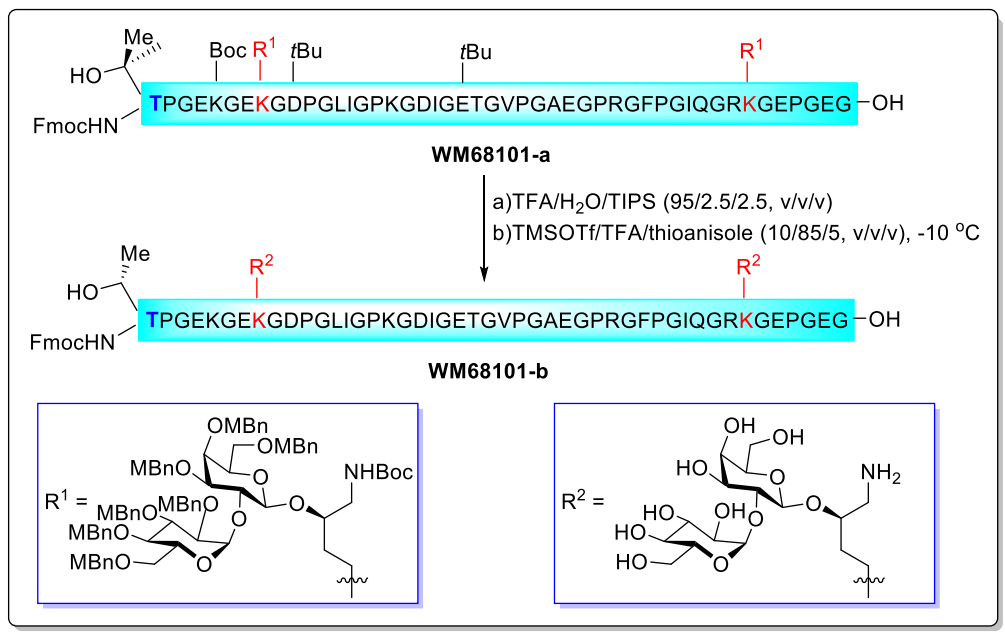


Peptide WM68101-a was synthesized according to the general procedure A using 2-chlorotrityl chloride resin $(50 \mathrm{mg})$ by introducing the glycosylated 5-hydroxylysine building-block at desired positions. Upon completion of synthesis, the crude peptide was then deprotected and cleaved from the resin using $5 \mathrm{~mL}$ TFA/TIPS/ $\mathrm{H}_{2} \mathrm{O}(90: 5: 5, \mathrm{v} / \mathrm{v} / \mathrm{v})$ for $1 \mathrm{~h}$. The resin was filtered and the combined filtrate was stirred at -10 ${ }^{\circ} \mathrm{C}$ in cooling bath for $10 \mathrm{~min}$. Then, thioanisole $625 \mu \mathrm{L}$ was added to the above solution and stirred for an additional $10 \mathrm{~min}$. TMSOTf $625 \mu \mathrm{L}$ was slowly added to the above solution and stirred at $-10{ }^{\circ} \mathrm{C}$ for 45 min. The reaction solution was poured into cold $\left(-20{ }^{\circ} \mathrm{C}\right)$ diethyl ether $(45 \mathrm{~mL})$, and the resulting suspension was centrifuged to give a white pellet. After decanting diethyl ether, the remaining solid was dissolved in $2 \mathrm{~mL} 50 \% \mathrm{CH}_{3} \mathrm{CN} / \mathrm{H}_{2} \mathrm{O}$ and $\mathrm{NH}_{4} \mathrm{HCO}_{3}$ solid was added until the solution $\mathrm{pH}$ became 7 . The resulting solution was stirred at room temperature for $1 \mathrm{~h}$ and subjected to preparative HPLC purification (20-50\% $\mathrm{CH}_{3} \mathrm{CN} / \mathrm{H}_{2} \mathrm{O}$ over $\left.45 \mathrm{~min}\right)$. Lyophilization afforded WM68101-b (16.8 $\mathrm{mg}, 12.3 \%$ ) as a white powder.

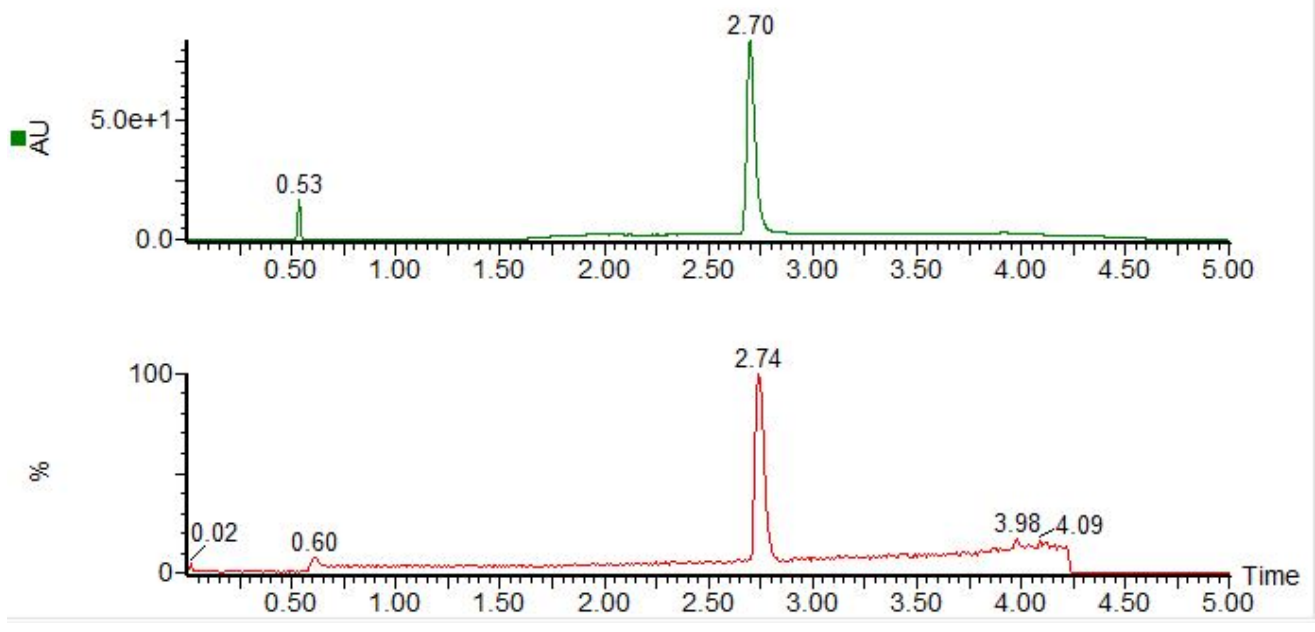

Figure 57. UV (190-400 nm) and MS (250-3000 m/z) traces from UPLC-MS analysis of purified WM68101-b (gradient 5-95\% $\mathrm{CH}_{3} \mathrm{CN} / \mathrm{H}_{2} \mathrm{O}$ containing $0.1 \%$ TFA over $5 \mathrm{~min}$ at a flow rate of 0.4 $\mathrm{mL} / \mathrm{min})$. 


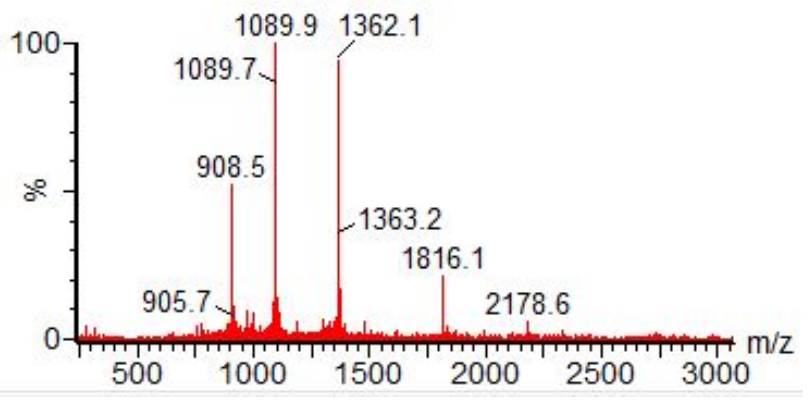

Figure 58. ESI-MS calcd. for $\mathrm{C}_{234} \mathrm{H}_{362} \mathrm{~N}_{58} \mathrm{O}_{91}$, $[\mathrm{M}+3 \mathrm{H}]^{3+} m / z=1815.6$, found $1816.1 ;[\mathrm{M}+4 \mathrm{H}]^{4+} m / z=$ 1362.0, found 1362.1; $[\mathrm{M}+5 \mathrm{H}]^{5+} \mathrm{m} / \mathrm{z}=1089.8$, found 1089.9; $[\mathrm{M}+6 \mathrm{H}]^{6+} \mathrm{m} / \mathrm{z}=908.3$, found 908.5 .

\subsection{Preparation of WM68101}

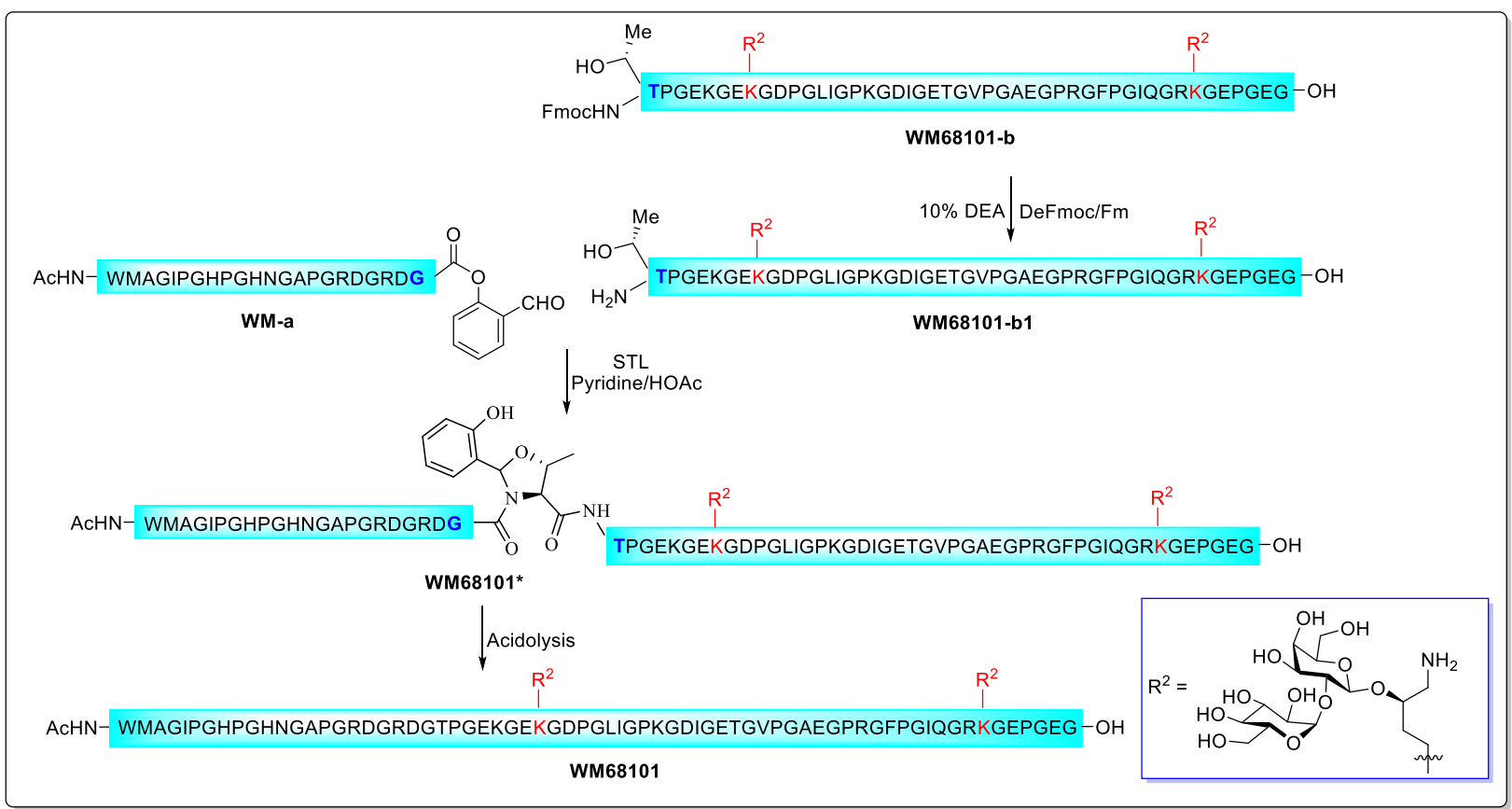

WM68101-b $(16.8 \mathrm{mg}, 3.08 \mu \mathrm{mol})$ was dissolved in $250 \mu \mathrm{L} \mathrm{CH}_{3} \mathrm{CN} / \mathrm{H}_{2} \mathrm{O} /$ diethylamine $(4.5 / 4.5 / 1$, v/v/v) at room temperature and stirred at room temperature for $2 \mathrm{~h}$ to give product WM68101-b1. The reaction 
mixture was diluted with $50 \% \mathrm{CH}_{3} \mathrm{CN} / \mathrm{H}_{2} \mathrm{O}(20 \mathrm{~mL})$ and subjected to lyophilization to afford WM68101b1 as a slightly yellow solid. This crude peptide was washed by diethyl ether. After that, WM68101-b1 and WM-a $(7.3 \mathrm{mg}, 5.78 \mu \mathrm{mol})$ were dissolved in pyridine/acetic acid $(1 / 1$, mole/mole) buffer at a concentration of $15 \mathrm{mM}$ at room temperature. The reaction mixture was stirred at room temperature for 4 $\mathrm{h}$ to give ligation intermediate WM68101*, and the solvent was then blown off under a stream of condensed $\mathrm{N}_{2}$. The residue was treated with $1 \mathrm{~mL}$ TFA/ $\mathrm{H}_{2} \mathrm{O}(95 / 5, \mathrm{v} / \mathrm{v})$ for $20 \mathrm{~min}$ to obtain crude product WM68101, and then TFA was blown off under a stream of condensed $\mathrm{N}_{2}$. The remaining residue was subjected to preparative HPLC purification $\left(10-35 \% \mathrm{CH}_{3} \mathrm{CN} / \mathrm{H}_{2} \mathrm{O}\right.$ over $\left.45 \mathrm{~min}\right)$ and lyophilization to afford WM68101 (6.1 mg, 26.5\%) as a white powder.

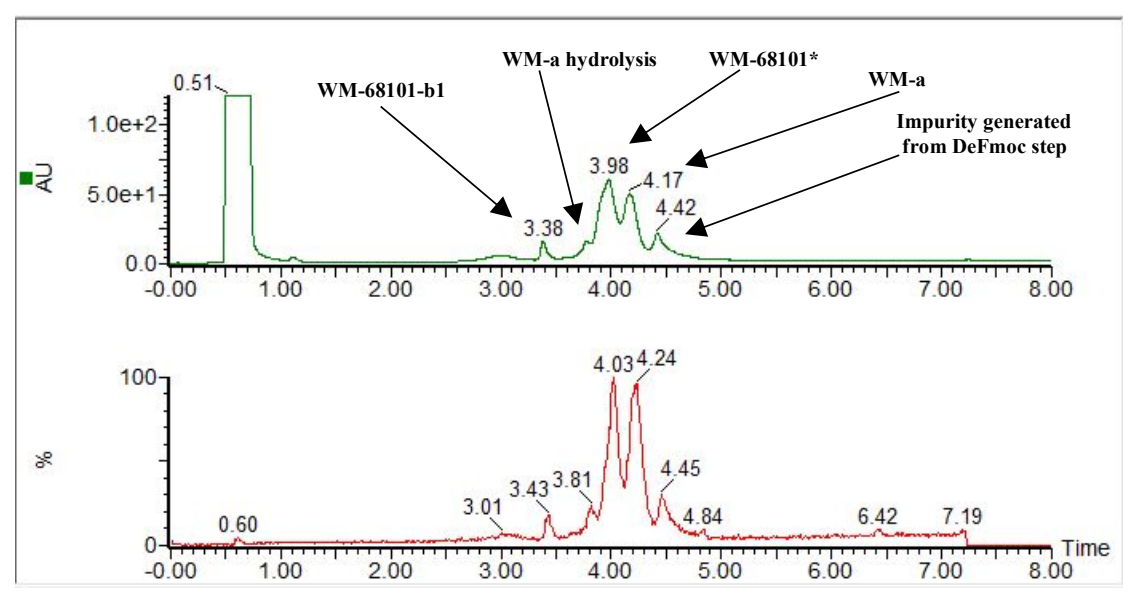

Figure 59. UV (190-400 nm) and MS (250-3000 m/z) traces from UPLC-MS analysis of STL between WM68101-b1 and WM-a at $4 \mathrm{~h}$ (gradient $10-50 \% \mathrm{CH}_{3} \mathrm{CN} / \mathrm{H}_{2} \mathrm{O}$ containing $0.1 \%$ TFA over 8 min at a flow rate of $0.4 \mathrm{~mL} / \mathrm{min})$. 

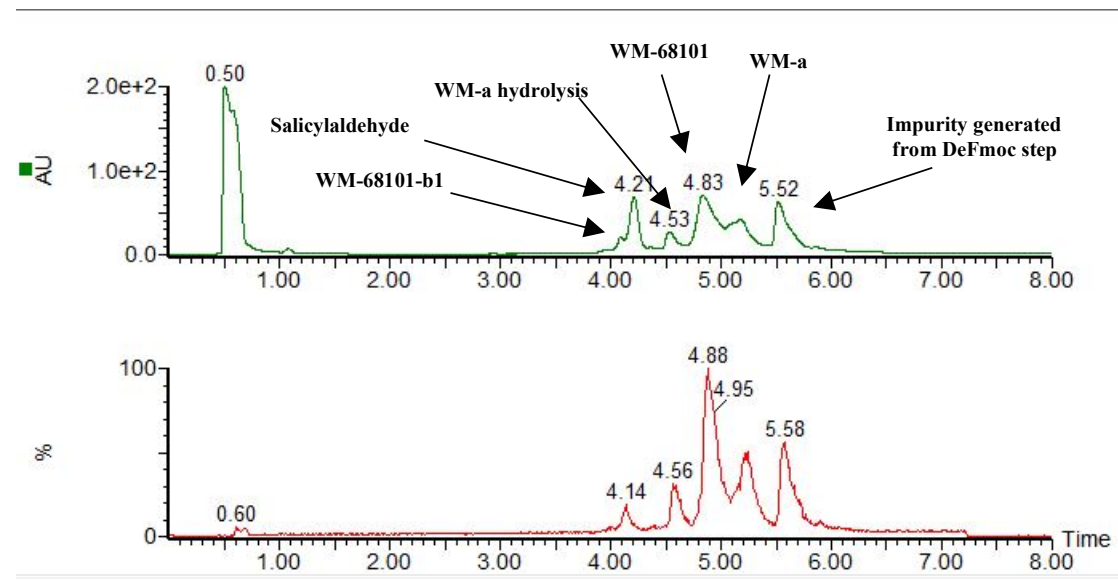

Figure 60. UV (190-400 nm) and MS (250-3000 m/z) traces from UPLC-MS analysis of STL acidolysis between WM68101-b1 and WM-a at $4 \mathrm{~h}$ (gradient $10-35 \% \mathrm{CH}_{3} \mathrm{CN} / \mathrm{H}_{2} \mathrm{O}$ containing $0.1 \%$ TFA over 8 min at a flow rate of $0.4 \mathrm{~mL} / \mathrm{min}$ ).

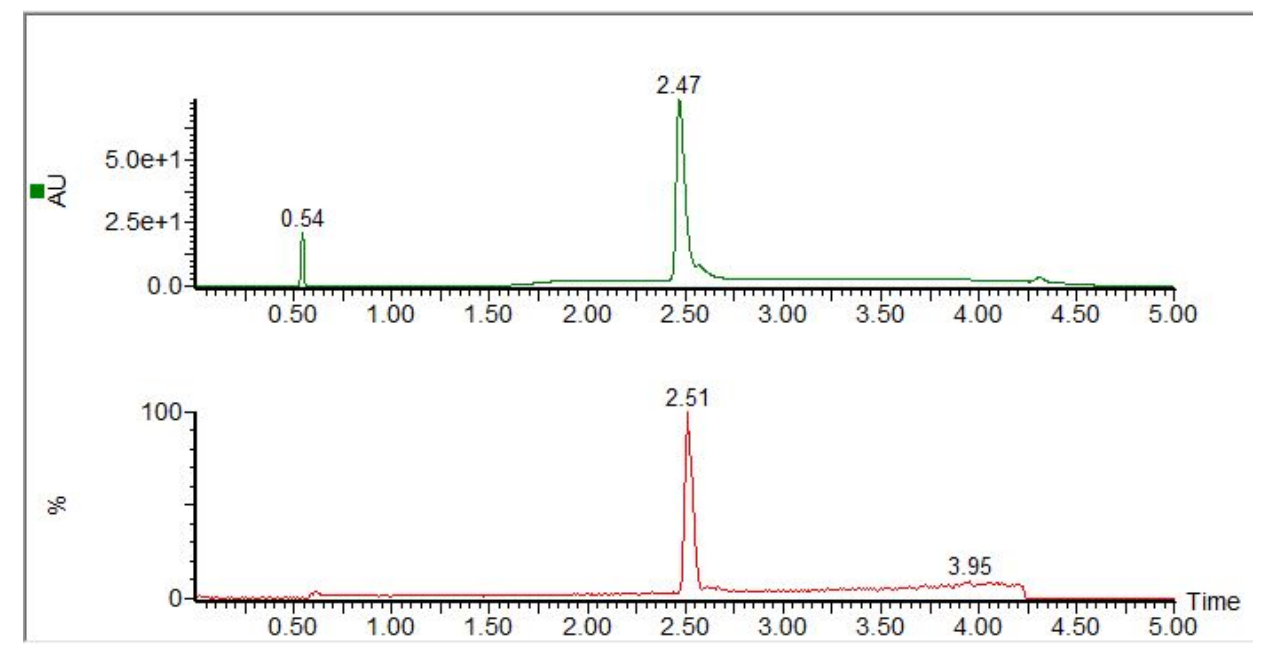

Figure 61. UV (190-400 nm) and MS (250-3000 m/z) traces from UPLC-MS analysis of purified WM68101 (gradient 5-95\% $\mathrm{CH}_{3} \mathrm{CN} / \mathrm{H}_{2} \mathrm{O}$ containing $0.1 \%$ TFA over $5 \mathrm{~min}$ at a flow rate of $0.4 \mathrm{~mL} / \mathrm{min}$ ). 


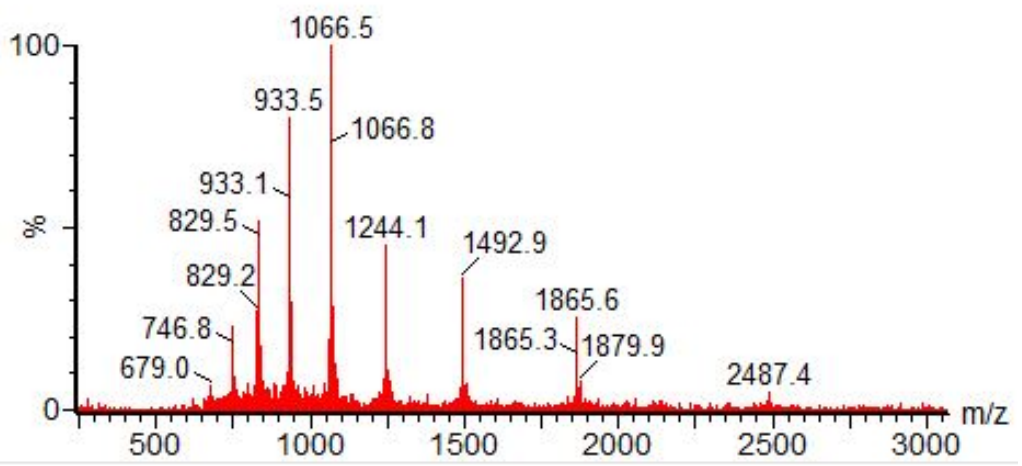

Figure 62. ESI-MS calcd. for $\mathrm{C}_{314} \mathrm{H}_{490} \mathrm{~N}_{92} \mathrm{O}_{117} \mathrm{~S}$, $[\mathrm{M}+3 \mathrm{H}]^{3+} \mathrm{m} / z=2487.0$, found 2487.4; $[\mathrm{M}+4 \mathrm{H}]^{4+} \mathrm{m} / z=$ 1865.5, found 1865.6; $[\mathrm{M}+5 \mathrm{H}]^{5+} \mathrm{m} / z=1492.6$, found 1492.9; $[\mathrm{M}+6 \mathrm{H}]^{6+} \mathrm{m} / \mathrm{z}=1244.0$, found 1244.1; $[\mathrm{M}+7 \mathrm{H}]^{7+} m / z=1066.4$, found 1066.5; $[\mathrm{M}+8 \mathrm{H}]^{8+} \mathrm{m} / \mathrm{z}=933.3$, found 933.5; $[\mathrm{M}+9 \mathrm{H}]^{9+} \mathrm{m} / \mathrm{z}=829.7$, found 829.5; $[\mathrm{M}+10 \mathrm{H}]^{10+} \mathrm{m} / z=746.8$, found 746.8 .

\section{Synthesis of peptide WM-77101}

\subsection{Preparation of WM77101b}

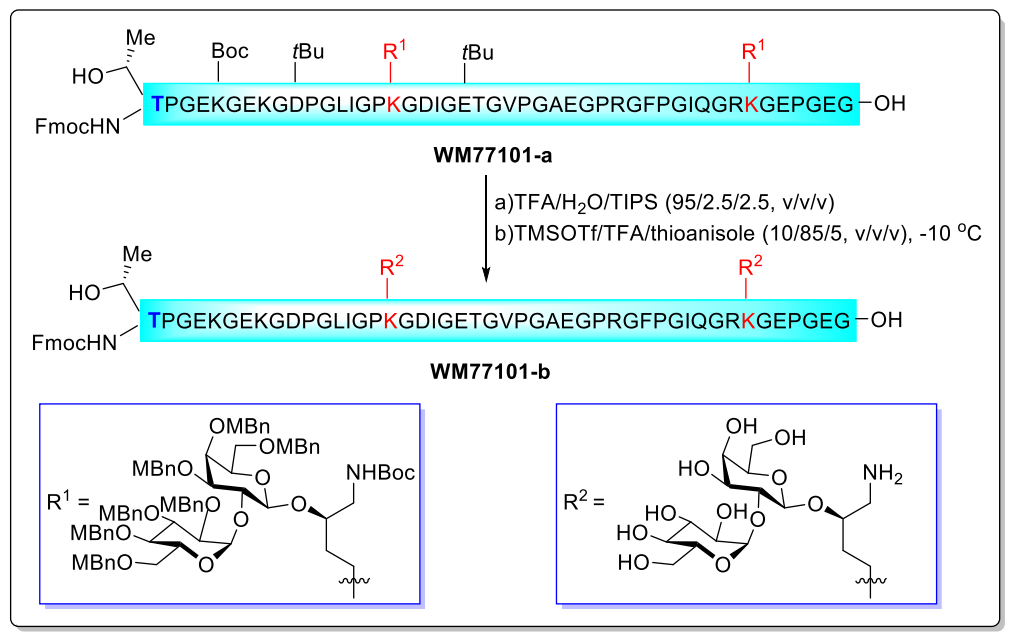

Peptide WM77101-a was synthesized according to the general procedure A using 2-chlorotrityl chloride resin $(50 \mathrm{mg})$ by introducing the glycosylated 5-hydroxylysine building-block at desired positions. Upon completion of synthesis, the crude peptide was then deprotected and cleaved from the resin using $5 \mathrm{~mL}$ 
TFA/TIPS/ $\mathrm{H}_{2} \mathrm{O}(90: 5: 5, \mathrm{v} / \mathrm{v} / \mathrm{v})$ for $1 \mathrm{~h}$. The resin was filtered and the combined filtrate was stirred at -10 ${ }^{\circ} \mathrm{C}$ in cooling bath for $10 \mathrm{~min}$. Then, thioanisole $625 \mu \mathrm{L}$ was added to the above solution and stirred for an additional $10 \mathrm{~min}$. TMSOTf $625 \mu \mathrm{L}$ was slowly added to the above solution and stirred at $-10{ }^{\circ} \mathrm{C}$ for 45 min. The reaction solution was poured into cold $\left(-20{ }^{\circ} \mathrm{C}\right)$ diethyl ether $(45 \mathrm{~mL})$, and the resulting suspension was centrifuged to give a white pellet. After decanting diethyl ether, the remaining solid was dissolved in $2 \mathrm{~mL} 50 \% \mathrm{CH}_{3} \mathrm{CN} / \mathrm{H}_{2} \mathrm{O}$ and $\mathrm{NH}_{4} \mathrm{HCO}_{3}$ solid was added until the solution $\mathrm{pH}$ became 7 . The resulting solution was stirred at room temperature for $1 \mathrm{~h}$ and subjected to preparative HPLC purification (20-50\% $\mathrm{CH}_{3} \mathrm{CN} / \mathrm{H}_{2} \mathrm{O}$ over $\left.45 \mathrm{~min}\right)$. Lyophilization afforded WM77101-b $(8.7 \mathrm{mg}, 6.4 \%)$ as a white powder.

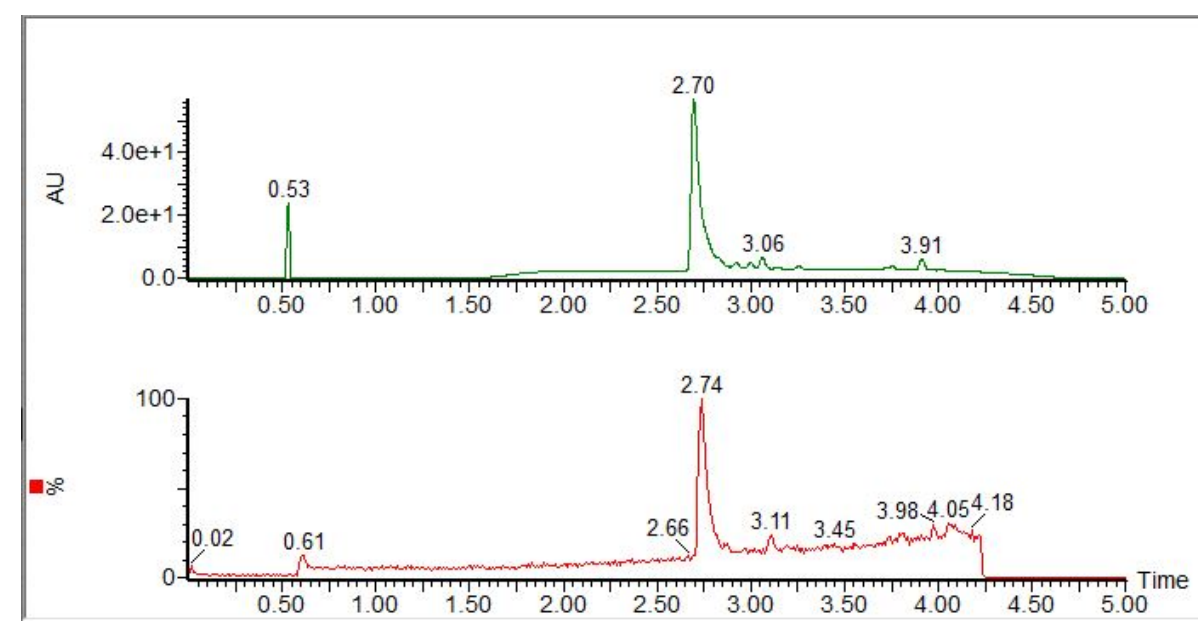

Figure 63. UV (190-400 $\mathrm{nm})$ and MS $(250-3000 \mathrm{~m} / \mathrm{z})$ traces from UPLC-MS analysis of purified WM77101-b (gradient 5-95\% $\mathrm{CH}_{3} \mathrm{CN} / \mathrm{H}_{2} \mathrm{O}$ containing $0.1 \%$ TFA over $5 \mathrm{~min}$ at a flow rate of 0.4 $\mathrm{mL} / \mathrm{min})$. 


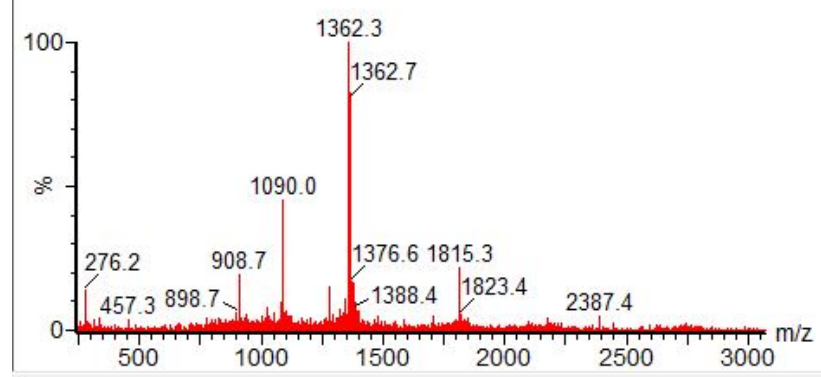

Figure 64. ESI-MS calcd. for $\mathrm{C}_{234} \mathrm{H}_{362} \mathrm{~N}_{58} \mathrm{O}_{91}$, $[\mathrm{M}+3 \mathrm{H}]^{3+} m / z=1815.6$, found 1815.3; $[\mathrm{M}+4 \mathrm{H}]^{4+} m / z=$ 1362.0, found 1362.3; $[\mathrm{M}+5 \mathrm{H}]^{5+} \mathrm{m} / z=1089.8$, found 1090.0; $[\mathrm{M}+6 \mathrm{H}]^{6+} \mathrm{m} / z=908.7$, found 908.7 .

\subsection{Preparation of WM77101}

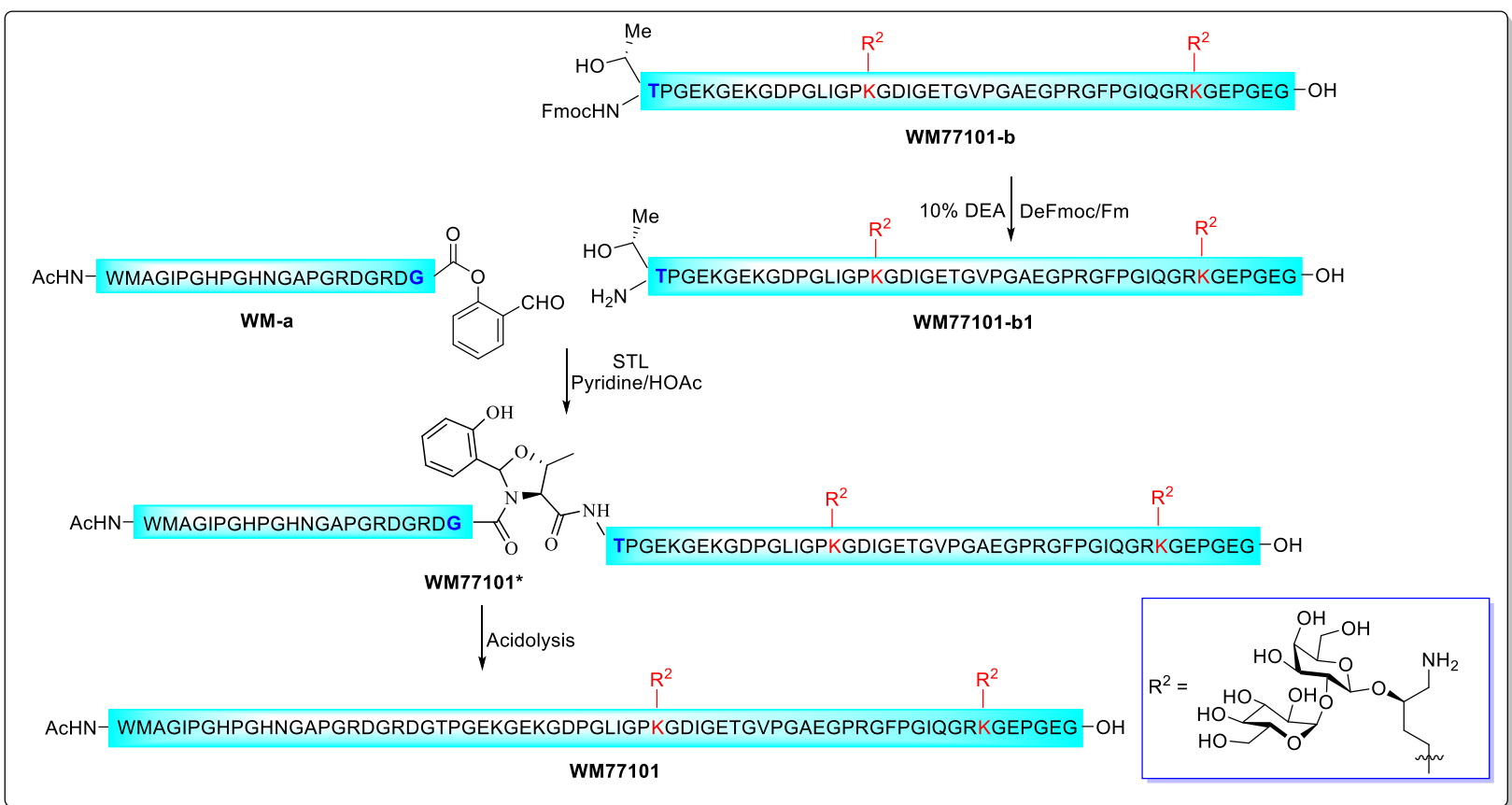

WM77101-b $(8.7 \mathrm{mg}, 1.60 \mu \mathrm{mol})$ was dissolved in $250 \mu \mathrm{L} \mathrm{CH}_{3} \mathrm{CN} / \mathrm{H}_{2} \mathrm{O} /$ diethylamine $(4.5 / 4.5 / 1, \mathrm{v} / \mathrm{v} / \mathrm{v})$ at room temperature and stirred at room temperature for $2 \mathrm{~h}$ to give product WM77101-b1. The reaction mixture was diluted with $50 \% \mathrm{CH}_{3} \mathrm{CN} / \mathrm{H}_{2} \mathrm{O}(20 \mathrm{~mL})$ and subjected to lyophilization to afford WM77101- 
b1 as a slightly yellow solid. This crude peptide was washed by diethyl ether. After that, WM77101-b1 and WM-a $(3.8 \mathrm{mg}, 1.60 \mu \mathrm{mol})$ were dissolved in pyridine/acetic acid $(1 / 1, \mathrm{~mole} / \mathrm{mole})$ buffer at a concentration of $15 \mathrm{mM}$ at room temperature. The reaction mixture was stirred at room temperature for 4 $\mathrm{h}$ to give ligation intermediate WM77101*, and the solvent was then blown off under a stream of condensed $\mathrm{N}_{2}$. The residue was treated with $1 \mathrm{~mL}$ TFA/ $\mathrm{H}_{2} \mathrm{O}(95 / 5, \mathrm{v} / \mathrm{v})$ for $20 \mathrm{~min}$ to obtain crude product WM77101, and the TFA was blown off tunder a stream of condensed $\mathrm{N}_{2}$. The remaining residue was subjected to preparative HPLC purification $\left(10-35 \% \mathrm{CH}_{3} \mathrm{CN} / \mathrm{H}_{2} \mathrm{O}\right.$ over $\left.45 \mathrm{~min}\right)$ and lyophilization to afford WM77101 (2.1 mg, 17.6\%) as a white powder.

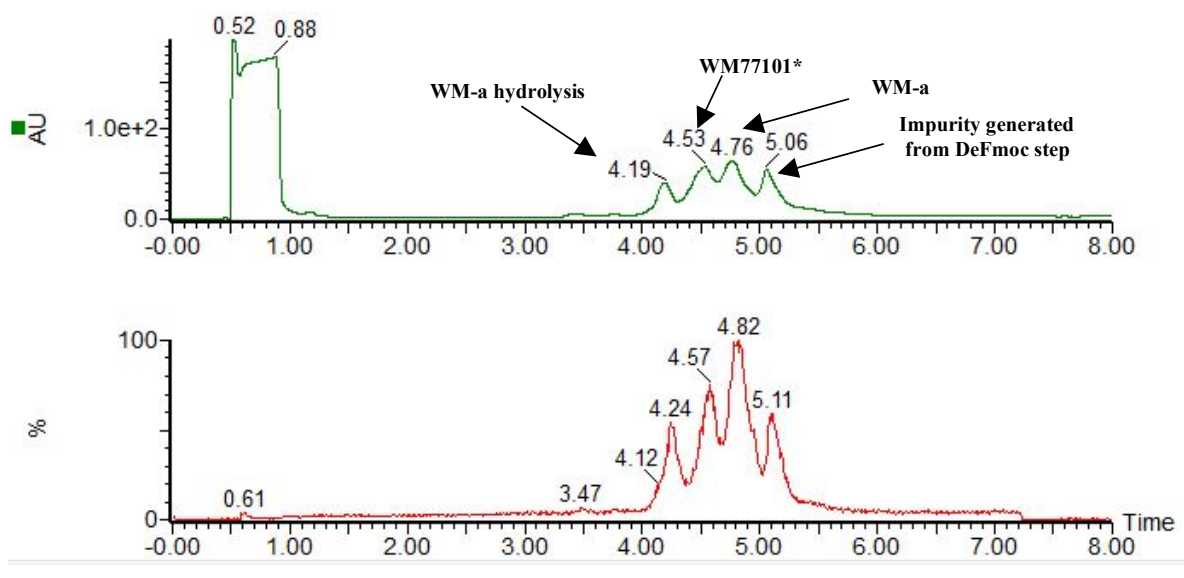

Figure 65. UV (190-400 nm) and MS (250-3000 m/z) traces from UPLC-MS analysis of STL between WM77101-a1 and WM-a at $4 \mathrm{~h}$ (gradient $10-50 \% \mathrm{CH}_{3} \mathrm{CN} / \mathrm{H}_{2} \mathrm{O}$ containing $0.1 \%$ TFA over 8 min at a flow rate of $0.4 \mathrm{~mL} / \mathrm{min})$. 


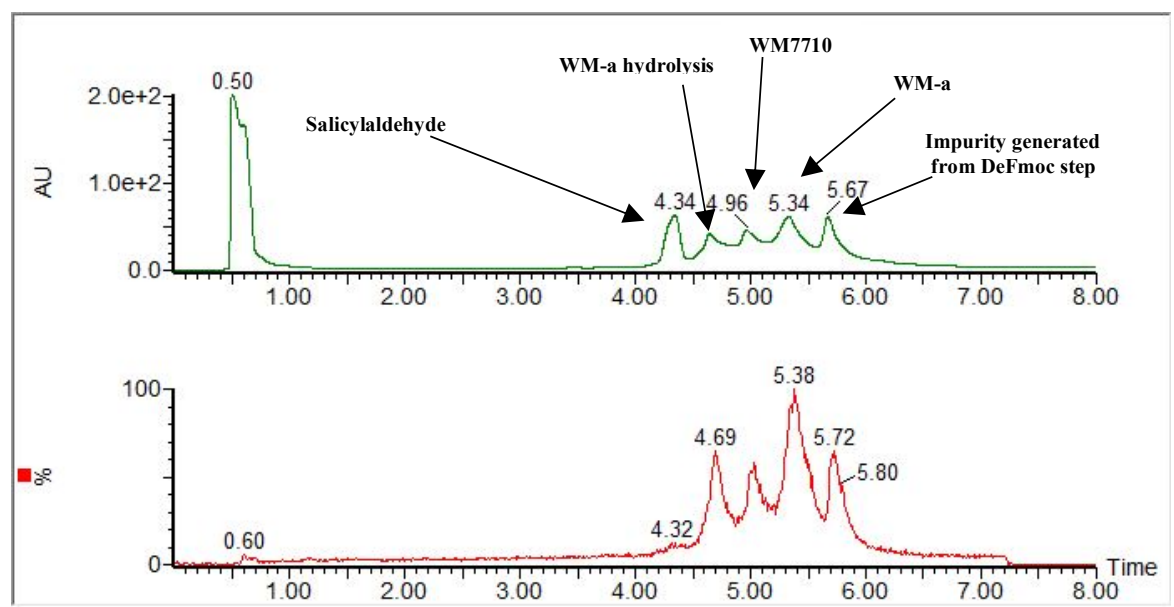

Figure 66. UV (190-400 nm) and MS (250-3000 m/z) traces from UPLC-MS analysis of STL acidolysis between WM77101-b1 and WM-a at $4 \mathrm{~h}$ (gradient $10-35 \% \mathrm{CH}_{3} \mathrm{CN} / \mathrm{H}_{2} \mathrm{O}$ containing $0.1 \%$ TFA over 8 $\min$ at a flow rate of $0.4 \mathrm{~mL} / \mathrm{min}$ ).

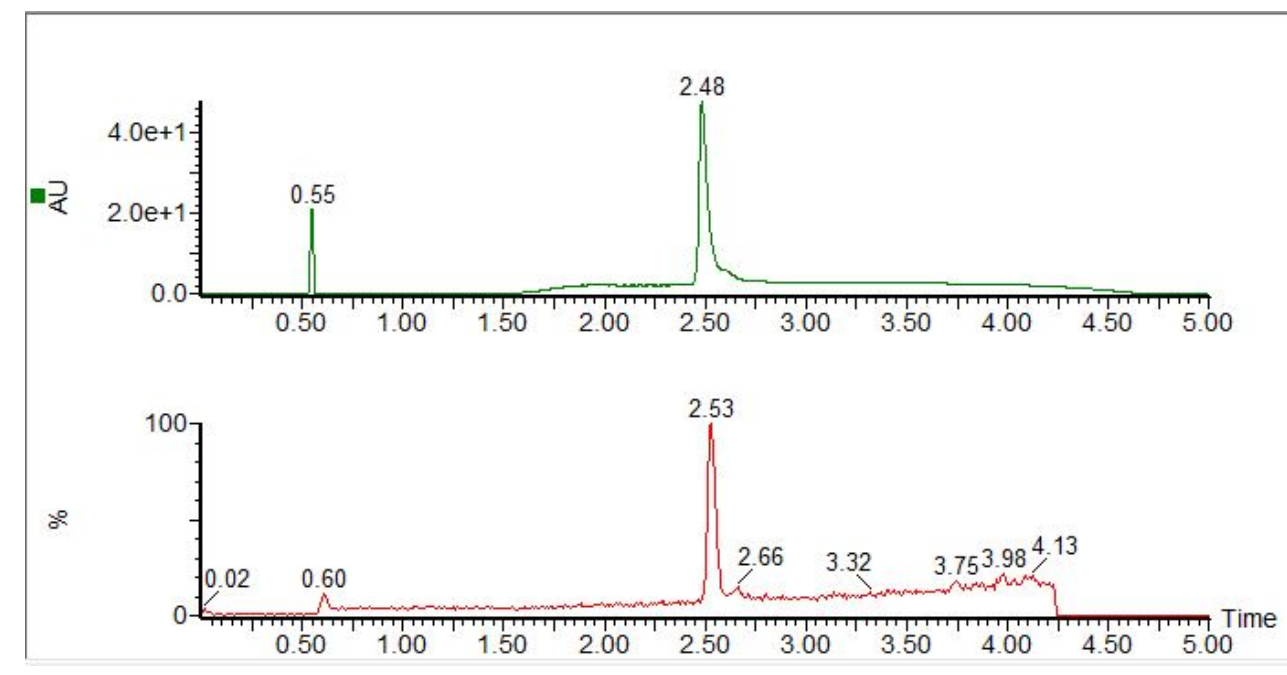

Figure 67. UV (190-400 nm) and MS (250-3000 m/z) traces from UPLC-MS analysis of purified WM77101 (gradient 5-95\% $\mathrm{CH}_{3} \mathrm{CN} / \mathrm{H}_{2} \mathrm{O}$ containing $0.1 \%$ TFA over $5 \mathrm{~min}$ at a flow rate of $0.4 \mathrm{~mL} / \mathrm{min}$ ). 


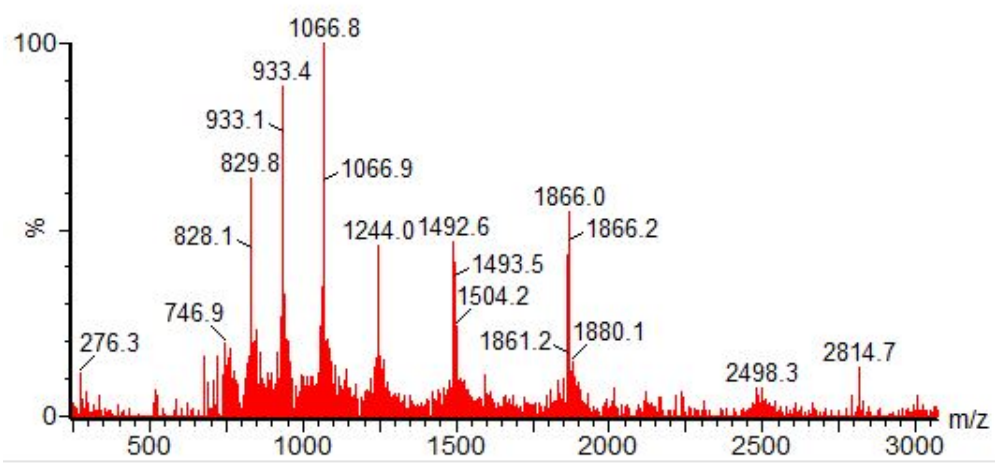

Figure 68. ESI-MS calcd. for $\mathrm{C}_{314} \mathrm{H}_{490} \mathrm{~N}_{92} \mathrm{O}_{117} \mathrm{~S}$, $[\mathrm{M}+4 \mathrm{H}]^{4+} \mathrm{m} / z=1865.5$, found $1866.0 ;[\mathrm{M}+5 \mathrm{H}]^{5+} m / z=$ 1492.6, found 1492.6; $[\mathrm{M}+6 \mathrm{H}]^{6+} \mathrm{m} / \mathrm{z}=1244.0$, found 1244.0; $[\mathrm{M}+7 \mathrm{H}]^{7+} \mathrm{m} / \mathrm{z}=1066.4$, found 1066.8; $[\mathrm{M}+8 \mathrm{H}]^{8+} m / z=933.3$, found 933.4; $[\mathrm{M}+9 \mathrm{H}]^{9+} \mathrm{m} / z=829.7$, found $829.8 ;[\mathrm{M}+10 \mathrm{H}]^{10+} \mathrm{m} / z=746.8$, found 746.9 .

\section{Synthesis of peptide WM-656877}

\subsection{Preparation of WM656877b}

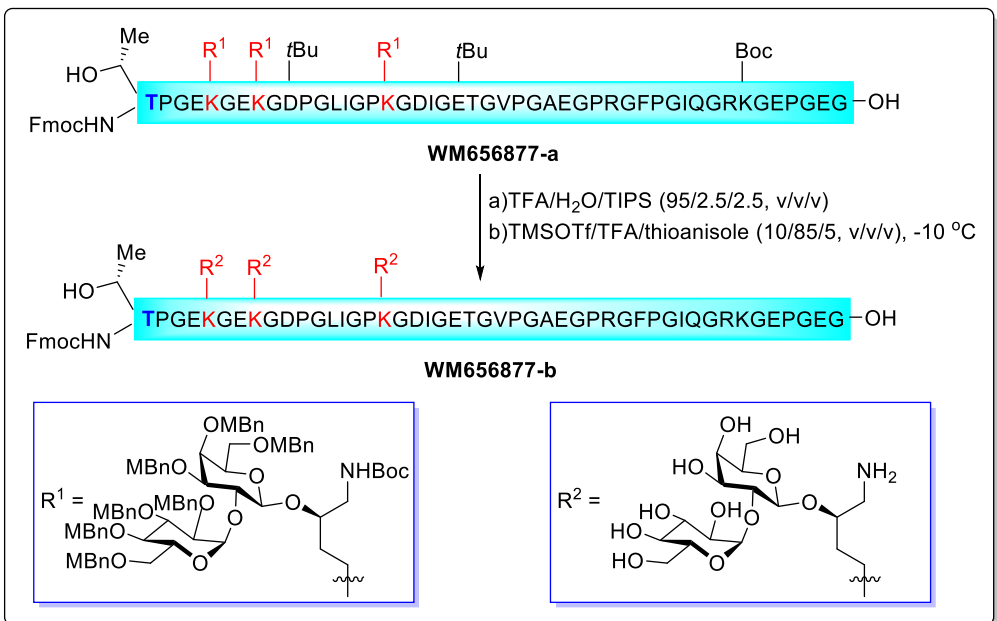

Peptide WM656877-a was synthesized according to the general procedure A using 2-chlorotrityl chloride resin $(50 \mathrm{mg})$ by introducing the glycosylated 5-hydroxylysine building-block at desired 
positions. Upon completion of synthesis, the crude peptide was then deprotected and cleaved from the resin using $5 \mathrm{~mL}$ TFA/TIPS/ $\mathrm{H}_{2} \mathrm{O}(90: 5: 5, \mathrm{v} / \mathrm{v} / \mathrm{v})$ for $1 \mathrm{~h}$. The resin was filtered and the combined filtrate was stirred at $-10{ }^{\circ} \mathrm{C}$ in cooling bath for $10 \mathrm{~min}$. Then, thioanisole $625 \mu \mathrm{L}$ was added to the above solution and stirred for an additional $10 \mathrm{~min}$. TMSOTf $625 \mu \mathrm{L}$ was slowly added to the above solution and stirred at $-10{ }^{\circ} \mathrm{C}$ for $45 \mathrm{~min}$. The reaction solution was poured into cold $(-20 \mathrm{oC})$ diethyl ether $(45$ $\mathrm{mL}$ ), and the resulting suspension was centrifuged to give a white pellet. After decanting diethyl ether, the remaining solid was dissolved in $2 \mathrm{~mL} 50 \% \mathrm{CH}_{3} \mathrm{CN} / \mathrm{H}_{2} \mathrm{O}$ and $\mathrm{NH}_{4} \mathrm{HCO}_{3}$ solid was added until the solution $\mathrm{pH}$ became 7 . The resulting solution was stirred at room temperature for $1 \mathrm{~h}$ and subjected to preparative HPLC purification $(20-50 \% \quad \mathrm{CH} 3 \mathrm{CN} / \mathrm{H} 2 \mathrm{O}$ over $45 \mathrm{~min})$. Lyophilization afforded WM656877-b (7.8 mg, 5.4\%) as a white powder.

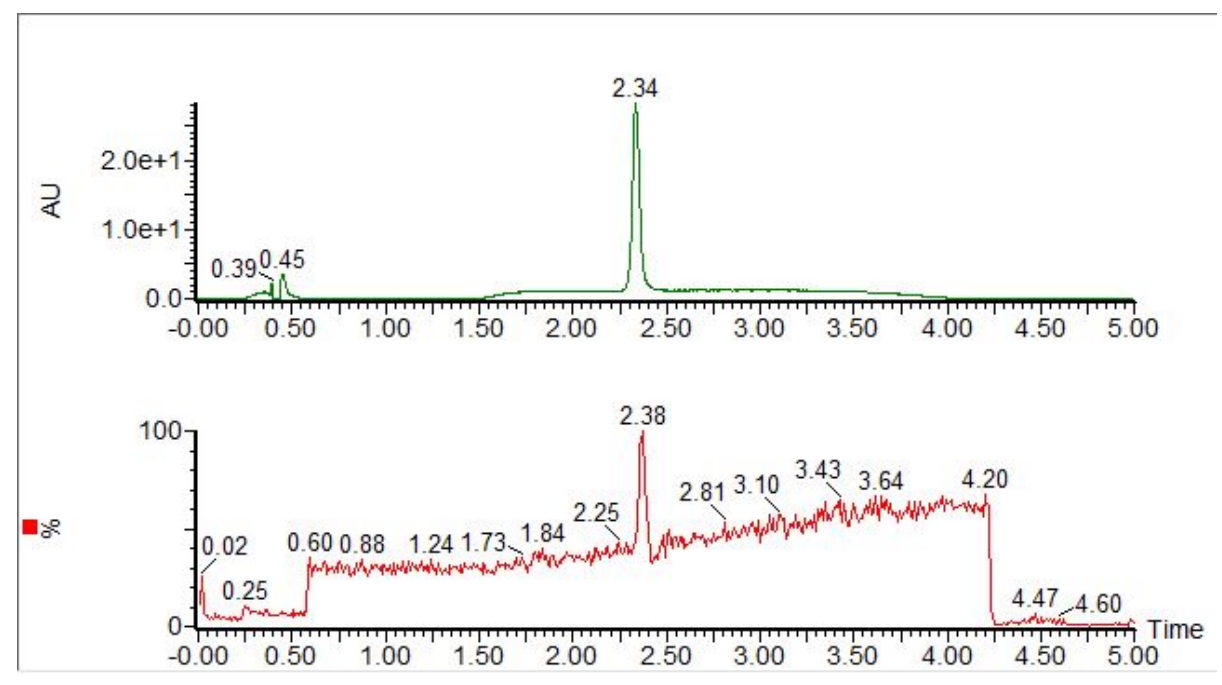

Figure 69. UV (190-400 nm) and MS (250-3000 m/z) traces from UPLC-MS analysis of purified WM656877-b (gradient 5-95\% $\mathrm{CH}_{3} \mathrm{CN} / \mathrm{H}_{2} \mathrm{O}$ containing $0.1 \%$ TFA over 5 min at a flow rate of 0.4 $\mathrm{mL} / \mathrm{min})$. 


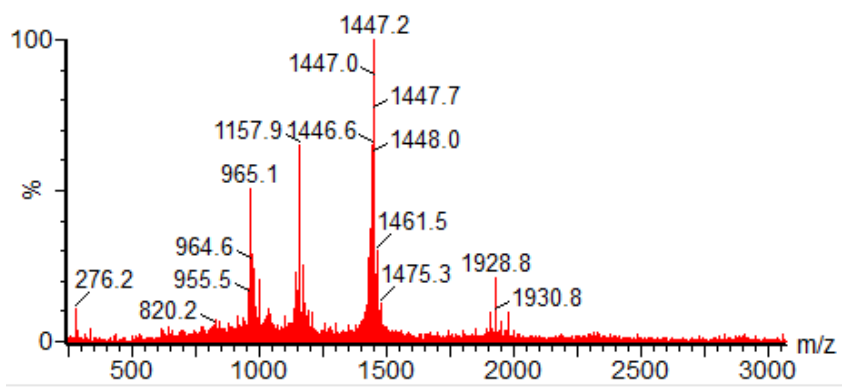

Figure 70. ESI-MS calcd. for $\mathrm{C}_{246} \mathrm{H}_{382} \mathrm{~N}_{58} \mathrm{O}_{102}$, $[\mathrm{M}+3 \mathrm{H}]^{3+} \mathrm{m} / z=1929.0$, found 1929.1; $[\mathrm{M}+4 \mathrm{H}]^{4+} \mathrm{m} / z=$ 1447.0, found 1447.2; $[\mathrm{M}+5 \mathrm{H}]^{5+} \mathrm{m} / z=1157.8$, found 1157.9; $[\mathrm{M}+6 \mathrm{H}]^{6+} \mathrm{m} / z=965.0$, found 965.1 .

\subsection{Preparation of WM656877}

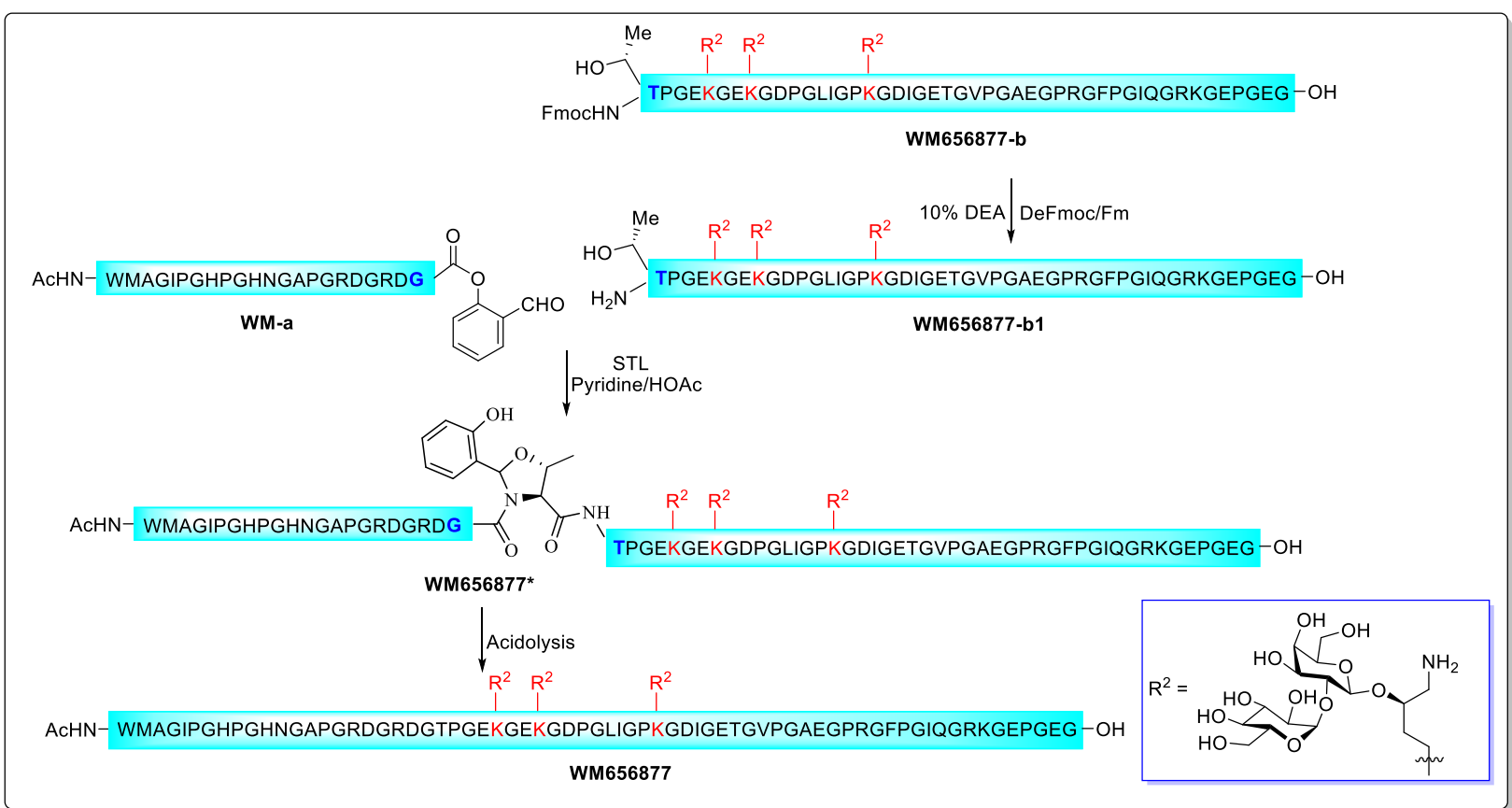

WM656877-b (7.8 mg, $1.35 \mu \mathrm{mol})$ was dissolved in $250 \mu \mathrm{L} \mathrm{CH}_{3} \mathrm{CN} / \mathrm{H}_{2} \mathrm{O} /$ diethylamine $(4.5 / 4.5 / 1$, v/v/v) at room temperature and stirred at room temperature for $2 \mathrm{~h}$ to give product $\mathbf{W M 6 5 6 8 7 7 - b 1}$. The reaction 
mixture was diluted with $50 \% \quad \mathrm{CH}_{3} \mathrm{CN} / \mathrm{H}_{2} \mathrm{O}(20 \mathrm{~mL})$ and subjected to lyophilization to afford WM656877-b1 as a slightly yellow solid. This crude peptide was washed by diethyl ether. After that, WM656877-b1 and WM-a $(3.2 \mathrm{mg}, 1.35 \mu \mathrm{mol})$ were dissolved in pyridine/acetic acid (1/1, mole/mole) buffer at a concentration of $15 \mathrm{mM}$ at room temperature. The reaction mixture was stirred at room

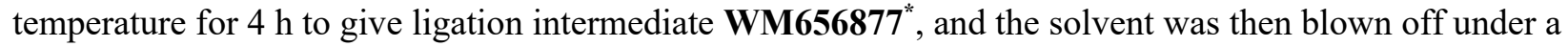
stream of condensed $\mathrm{N}_{2}$. The residue was treated with $1 \mathrm{~mL}$ TFA/ $\mathrm{H}_{2} \mathrm{O}(95 / 5, \mathrm{v} / \mathrm{v})$ for 20 min to obtain crude product WM656877, and the TFA was blown off under a stream of condensed $\mathrm{N}_{2}$. The remaining residue was subjected to preparative HPLC purification $\left(10-35 \% \quad \mathrm{CH}_{3} \mathrm{CN} / \mathrm{H}_{2} \mathrm{O}\right.$ over $45 \mathrm{~min}$ ) and lyophilization to afford WM656877 (1.8 $\mathrm{mg}, 17.1 \%)$ as a white powder.
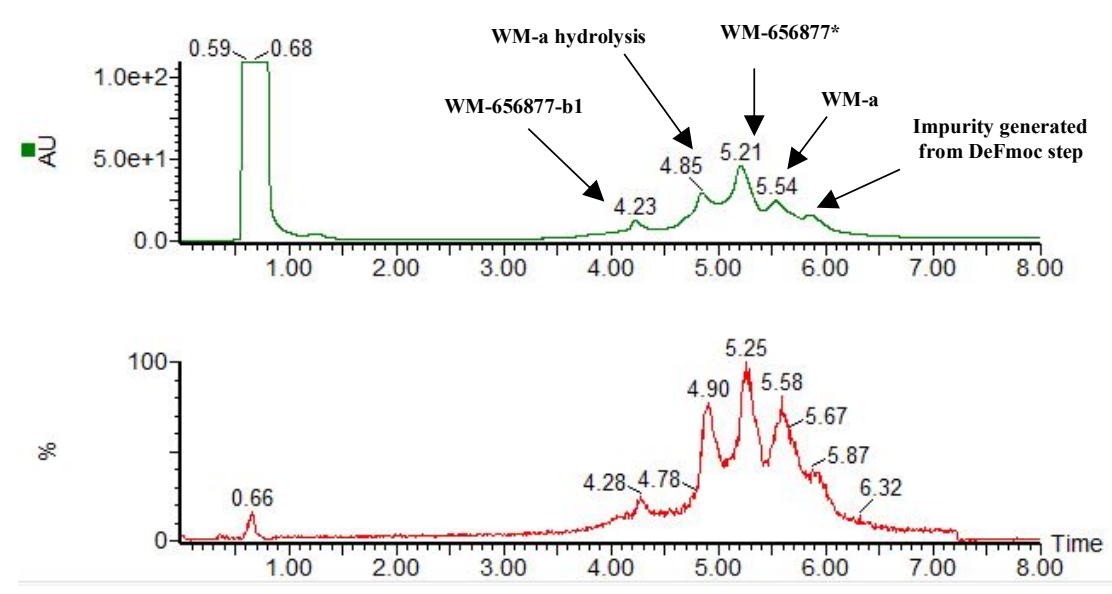

Figure 71. UV (190-400 nm) and MS (250-3000 m/z) traces from UPLC-MS analysis of STL between WM656877-b1 and WM-a at $4 \mathrm{~h}$ (gradient $10-50 \% \mathrm{CH}_{3} \mathrm{CN} / \mathrm{H}_{2} \mathrm{O}$ containing $0.1 \%$ TFA over 8 min at a flow rate of $0.4 \mathrm{~mL} / \mathrm{min})$. 

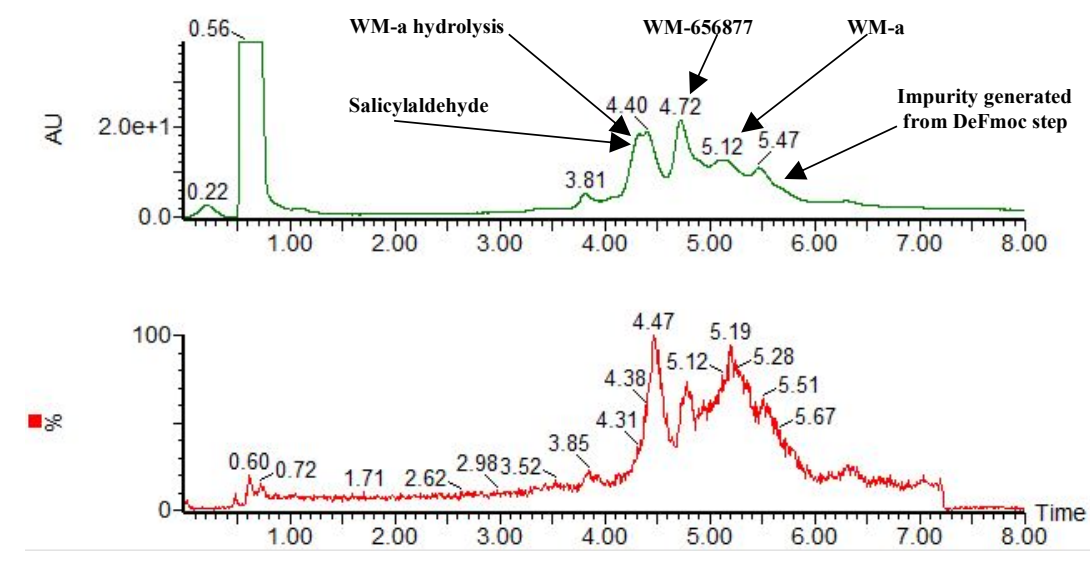

Figure 72. UV (190-400 nm) and MS (250-3000 m/z) traces from UPLC-MS analysis of STL acidolysis between WM656877-b1 and WM-a at $4 \mathrm{~h}$ (gradient 10-35\% $\mathrm{CH}_{3} \mathrm{CN} / \mathrm{H}_{2} \mathrm{O}$ containing $0.1 \%$ TFA over 8 $\min$ at a flow rate of $0.4 \mathrm{~mL} / \mathrm{min}$ ).
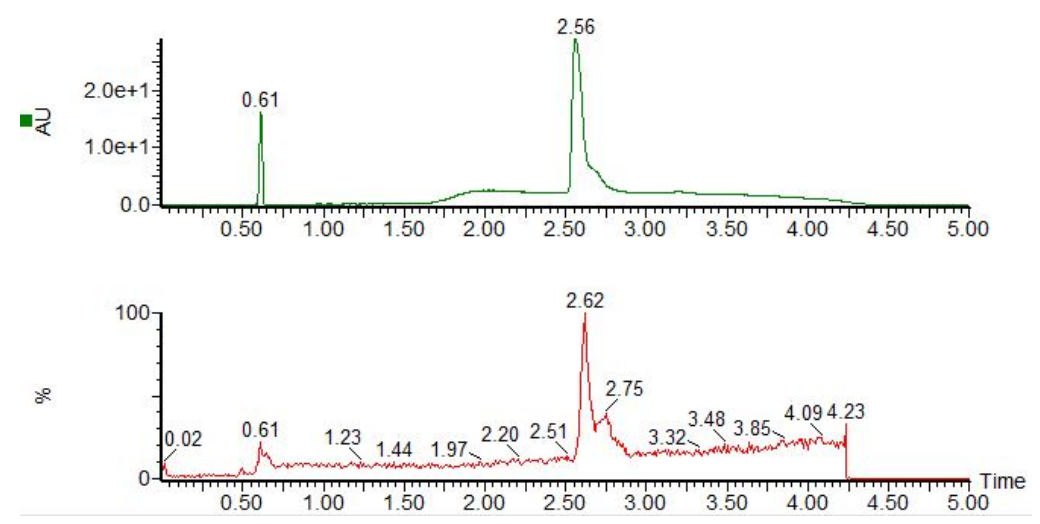

Figure 73. UV (190-400 nm) and MS (250-3000 m/z) traces from UPLC-MS analysis of purified WM656877 (gradient 5-95\% $\mathrm{CH}_{3} \mathrm{CN} / \mathrm{H}_{2} \mathrm{O}$ containing $0.1 \%$ TFA over $5 \mathrm{~min}$ at a flow rate of $0.4 \mathrm{~mL} / \mathrm{min}$ ). 


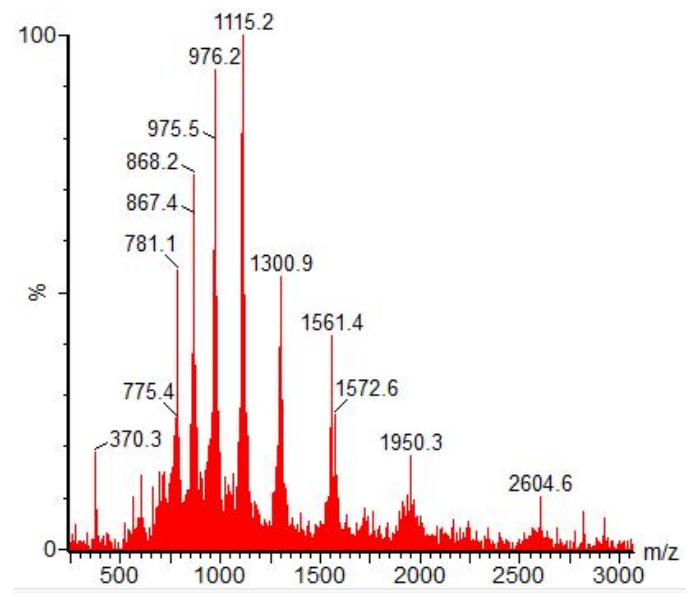

Figure 74. ESI-MS calcd. for $\mathrm{C}_{326} \mathrm{H}_{510} \mathrm{~N}_{92} \mathrm{O}_{128} \mathrm{~S}$, $[\mathrm{M}+4 \mathrm{H}]^{4+} \mathrm{m} / z=1950.6$, found $1950.3 ;[\mathrm{M}+5 \mathrm{H}]^{5+} \mathrm{m} / z$ $=1560.7$, found 1561.4; $[\mathrm{M}+6 \mathrm{H}]^{6+} \mathrm{m} / z=1300.7$, found 1300.9; $[\mathrm{M}+7 \mathrm{H}]^{7+} \mathrm{m} / z=1115.0$, found 1115.2; $[\mathrm{M}+8 \mathrm{H}]^{8+} m / z=975.8$, found 976.2; $[\mathrm{M}+9 \mathrm{H}]^{9+} \mathrm{m} / \mathrm{z}=867.5$, found $868.2 ;[\mathrm{M}+10 \mathrm{H}]^{10+} \mathrm{m} / \mathrm{z}=780.8$, found 781.1

\section{Synthesis of peptide WM-6568101}

\subsection{Preparation of WM6568101b}

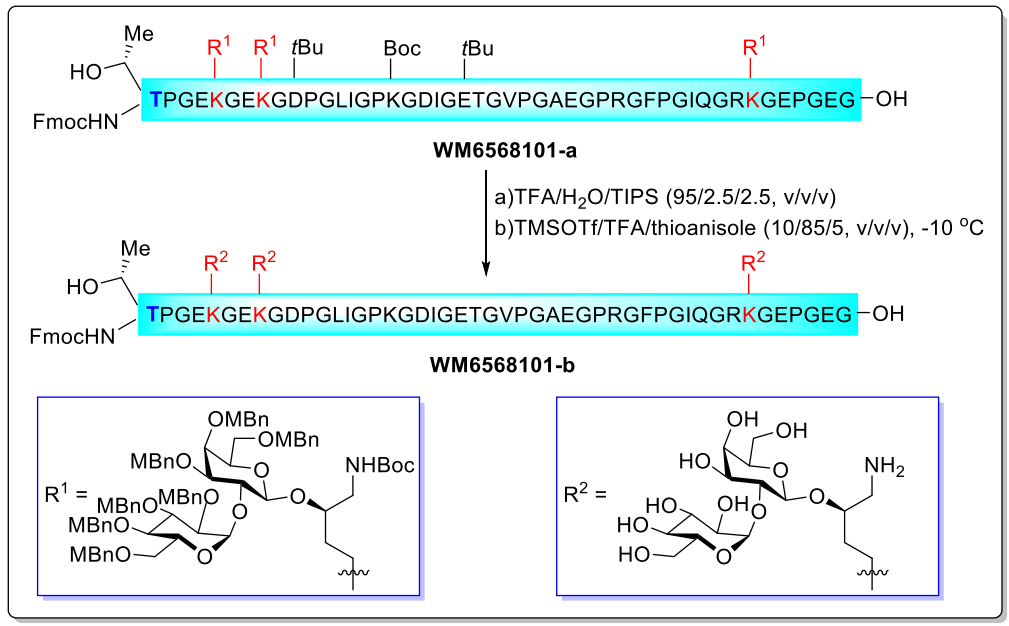


Peptide WM6568101-a was synthesized according to the general procedure A using 2-chlorotrityl chloride resin $(50 \mathrm{mg})$ by introducing the glycosylated 5-hydroxylysine building-block at desired positions. Upon completion of synthesis, the crude peptide was then deprotected and cleaved from the resin using $5 \mathrm{~mL}$ TFA/TIPS/ $\mathrm{H}_{2} \mathrm{O}(90: 5: 5, \mathrm{v} / \mathrm{v} / \mathrm{v})$ for $1 \mathrm{~h}$. The resin was filtered and the combined filtrate was stirred at $-10{ }^{\circ} \mathrm{C}$ in cooling bath for $10 \mathrm{~min}$. Then, thioanisole $625 \mu \mathrm{L}$ was added to the above solution and stirred for an additional $10 \mathrm{~min}$. TMSOTf $625 \mu \mathrm{L}$ was slowly added to the above solution and stirred at $-10{ }^{\circ} \mathrm{C}$ for $45 \mathrm{~min}$. The reaction solution was poured into cold $\left(-20^{\circ} \mathrm{C}\right)$ diethyl ether $(45 \mathrm{~mL})$, and the resulting suspension was centrifuged to give a white pellet. After decanting diethyl ether, the remaining solid was dissolved in $2 \mathrm{~mL} 50 \% \mathrm{CH}_{3} \mathrm{CN} / \mathrm{H}_{2} \mathrm{O}$ and $\mathrm{NH}_{4} \mathrm{HCO}_{3}$ solid was added until the solution $\mathrm{pH}$ became 7. The resulting solution was stirred at room temperature for $1 \mathrm{~h}$ and subjected to preparative HPLC purification $\left(20-50 \% \quad \mathrm{CH}_{3} \mathrm{CN} / \mathrm{H}_{2} \mathrm{O}\right.$ over $\left.45 \mathrm{~min}\right)$. Lyophilization afforded WM6568101-b (8.3 mg, 5.7\%) as a white powder.
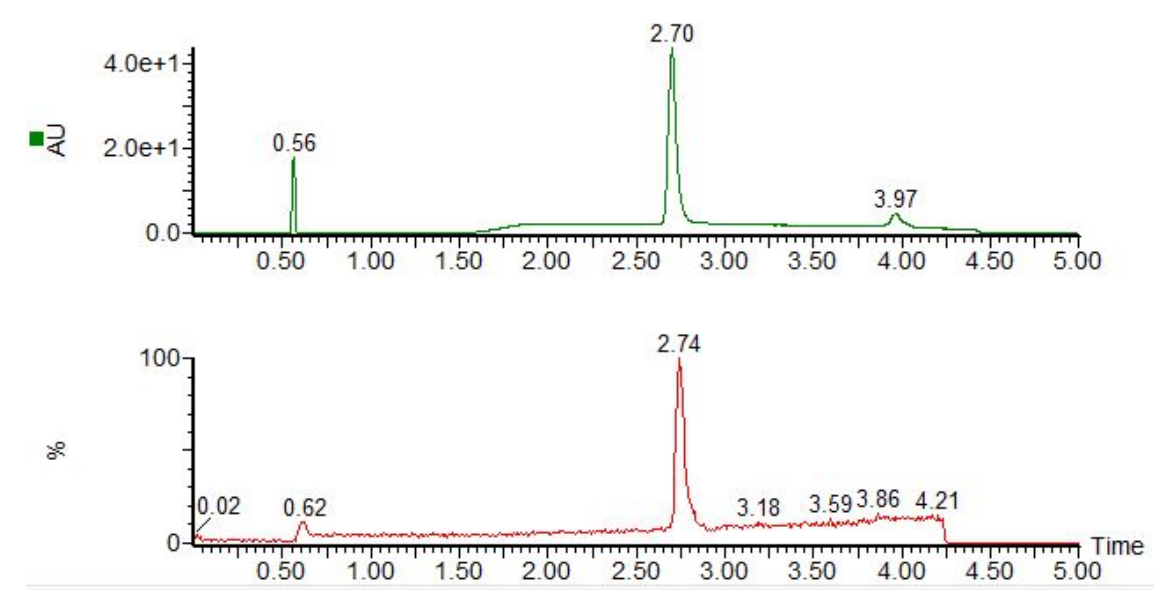

Figure 75. UV (190-400 nm) and MS (250-3000 m/z) traces from UPLC-MS analysis of purified WM6568101-b (gradient 5-95\% $\mathrm{CH}_{3} \mathrm{CN} / \mathrm{H}_{2} \mathrm{O}$ containing $0.1 \%$ TFA over $5 \mathrm{~min}$ at a flow rate of 0.4 $\mathrm{mL} / \mathrm{min})$ 


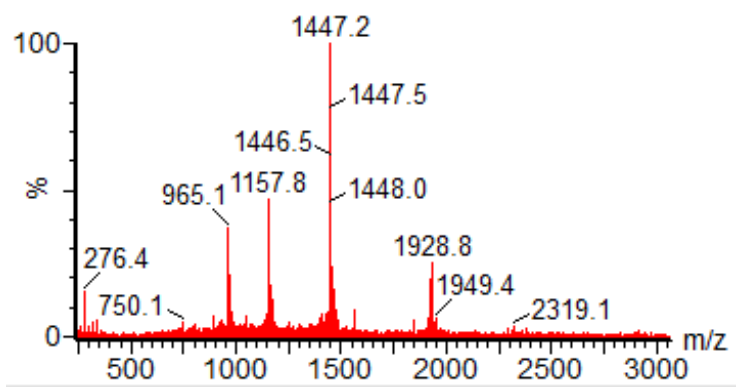

Figure 76. ESI-MS calcd. for $\mathrm{C}_{246} \mathrm{H}_{382} \mathrm{~N}_{58} \mathrm{O}_{102}$, $[\mathrm{M}+3 \mathrm{H}]^{3+} \mathrm{m} / \mathrm{z}=1929.1$, found 1928.8; $[\mathrm{M}+4 \mathrm{H}]^{4+} \mathrm{m} / z=$ 1447.0, found 1447.2; $[\mathrm{M}+5 \mathrm{H}]^{5+} \mathrm{m} / \mathrm{z}=1157.8$, found 1157.8; $[\mathrm{M}+6 \mathrm{H}]^{6+} \mathrm{m} / \mathrm{z}=965.0$, found 965.1 .

\subsection{Preparation of WM6568101}

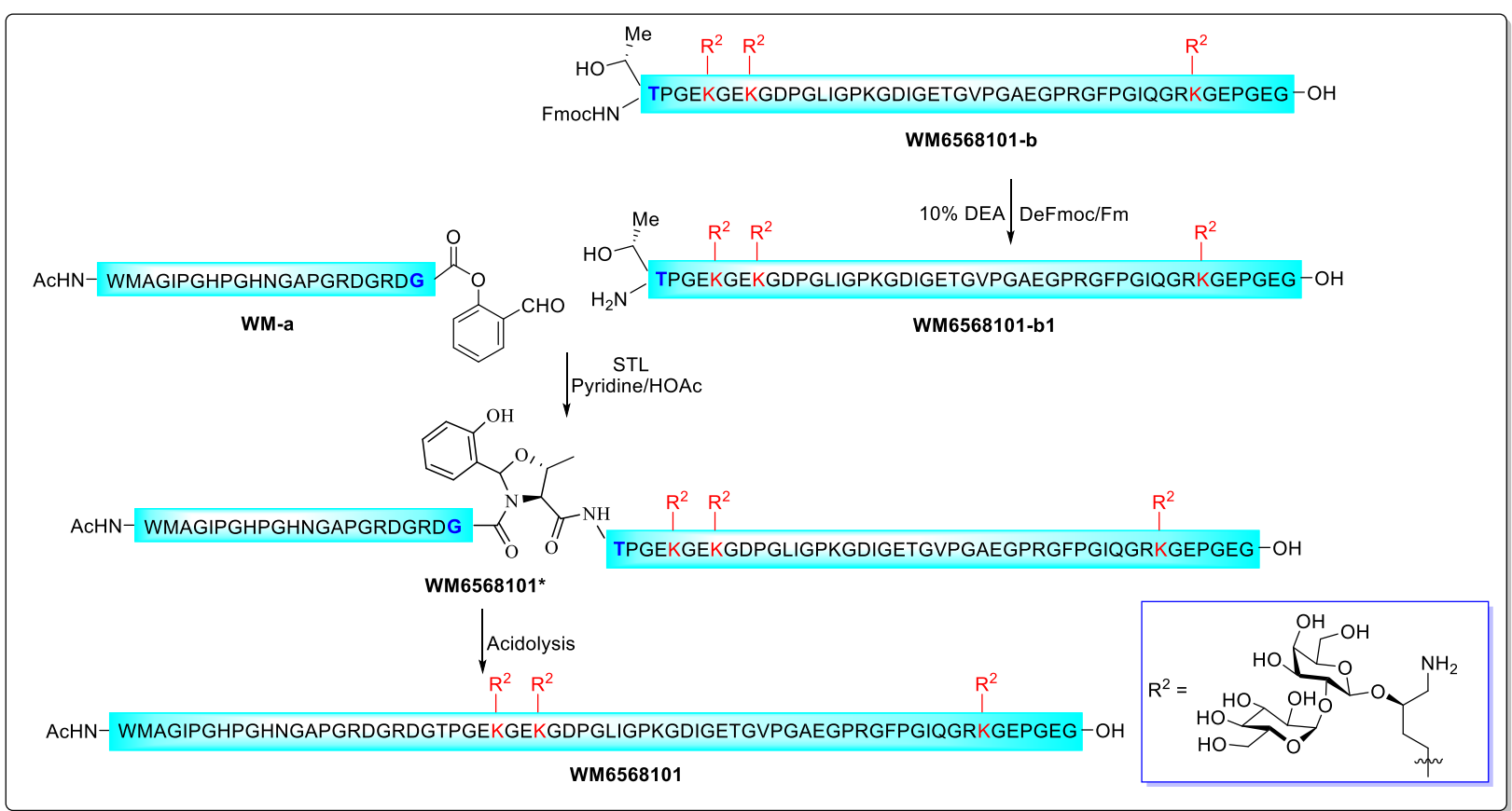

WM6568101-b $(8.3 \mathrm{mg}, 1.43 \mu \mathrm{mol})$ was dissolved in $250 \mu \mathrm{CH}_{3} \mathrm{CN} / \mathrm{H}_{2} \mathrm{O} /$ diethylamine $(4.5 / 4.5 / 1$, v/v/v) at room temperature and stirred at room temperature for $2 \mathrm{~h}$ to give product WM6568101-b1. The reaction mixture was diluted with $50 \% \mathrm{CH}_{3} \mathrm{CN} / \mathrm{H}_{2} \mathrm{O}(20 \mathrm{~mL})$ and subjected to lyophilization to afford 
WM6568101-b1 as a slightly yellow solid. This crude peptide was washed by diethyl ether. After that, WM6568101-b1 and WM-a (3.4 mg, $1.43 \mu \mathrm{mol})$ were dissolved in pyridine/acetic acid (1/1, mole/mole) buffer at a concentration of $15 \mathrm{mM}$ at room temperature. The reaction mixture was stirred at room temperature for $4 \mathrm{~h}$ to give ligation intermediate $\mathbf{W M 6 5 6 8 1 0 1}{ }^{*}$, and the solvent was then blown off under a stream of condensed $\mathrm{N}_{2}$. The residue was treated with $1 \mathrm{~mL} \mathrm{TFA} / \mathrm{H}_{2} \mathrm{O}(95 / 5, \mathrm{v} / \mathrm{v})$ for 20 min to obtain crude product WM6568101, and the TFA was blown off under a stream of condensed $\mathrm{N}_{2}$. The remaining residue was subjected to preparative HPLC purification $\left(10-35 \% \quad \mathrm{CH}_{3} \mathrm{CN} / \mathrm{H}_{2} \mathrm{O}\right.$ over $\left.45 \mathrm{~min}\right)$ and lyophilization to afford WM6568101 (1.9 mg, 17.0\%) as a white powder.

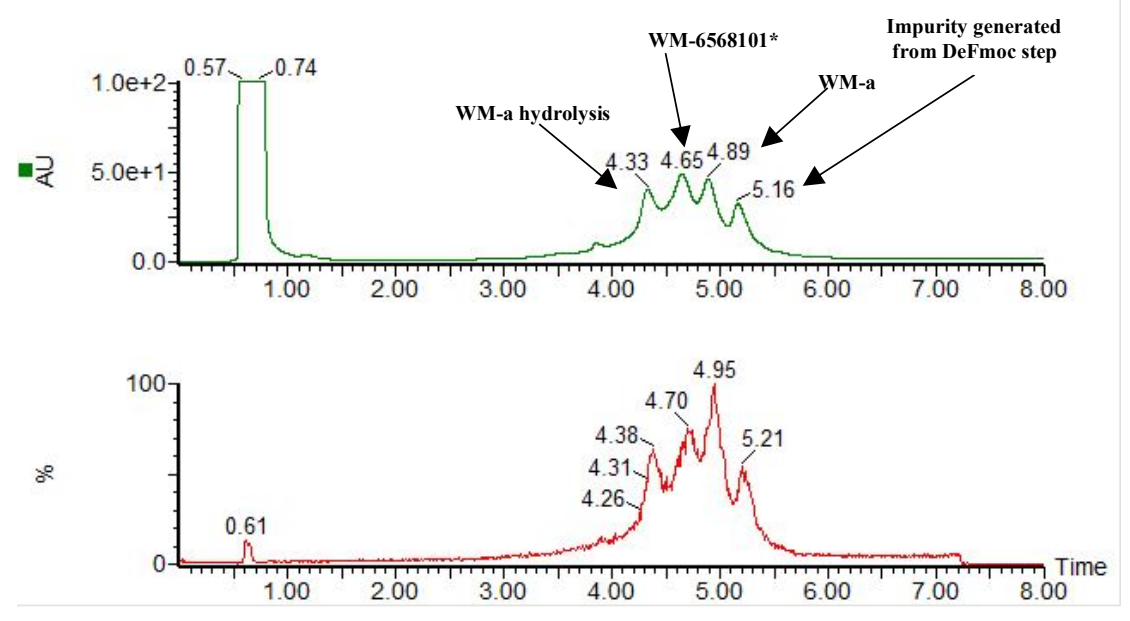

Figure 77. UV (190-400 $\mathrm{nm})$ and MS (250-3000 m/z) traces from UPLC-MS analysis of STL between WM6568101-b1 and WM-a at $4 \mathrm{~h}$ (gradient $10-50 \% \mathrm{CH}_{3} \mathrm{CN} / \mathrm{H}_{2} \mathrm{O}$ containing $0.1 \%$ TFA over 8 min at a flow rate of $0.4 \mathrm{~mL} / \mathrm{min}$ ). 


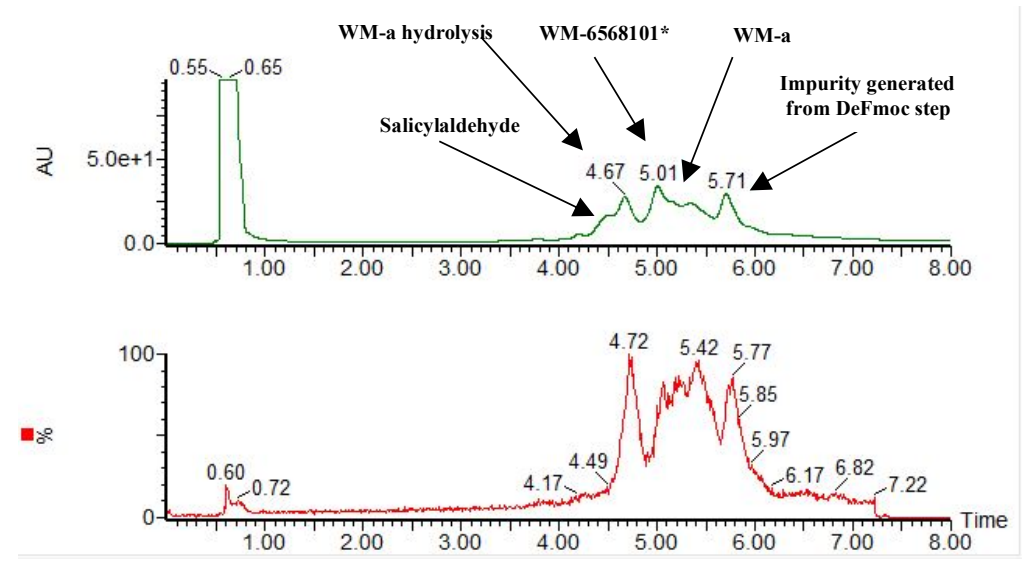

Figure 78. UV (190-400 nm) and MS (250-3000 m/z) traces from UPLC-MS analysis of STL acidolysis between WM6568101-b1 and WM-a at $4 \mathrm{~h}$ (gradient 10-35\% $\mathrm{CH}_{3} \mathrm{CN} / \mathrm{H}_{2} \mathrm{O}$ containing $0.1 \%$ TFA over 8 min at a flow rate of $0.4 \mathrm{~mL} / \mathrm{min}$ ).
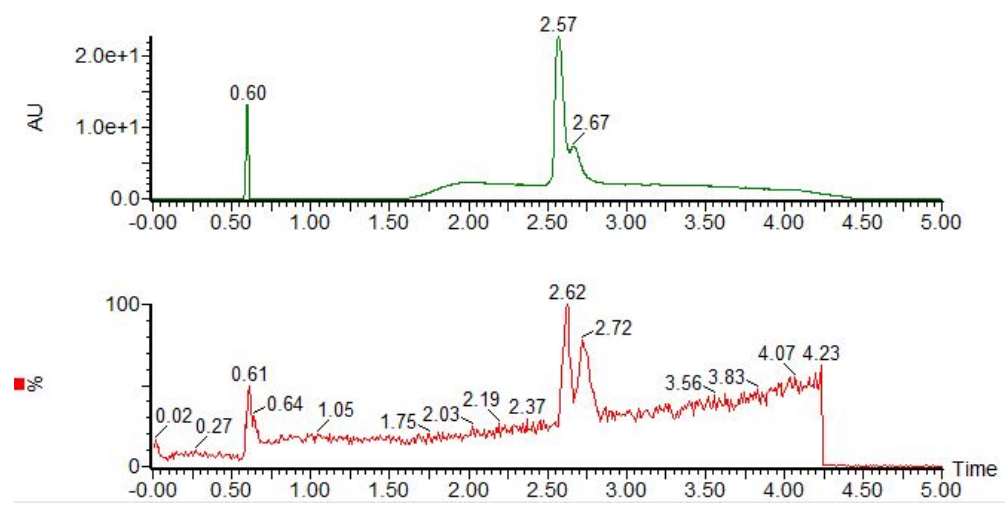

Figure 79. UV (190-400 nm) and MS (250-3000 m/z) traces from UPLC-MS analysis of purified WM6568101 (gradient 5-95\% $\mathrm{CH}_{3} \mathrm{CN} / \mathrm{H}_{2} \mathrm{O}$ containing $0.1 \%$ TFA over $5 \mathrm{~min}$ at a flow rate of 0.4 $\mathrm{mL} / \mathrm{min}) ;(2.67 \mathrm{~min}$ peak is a low molecular weight impurity from the previous step). 


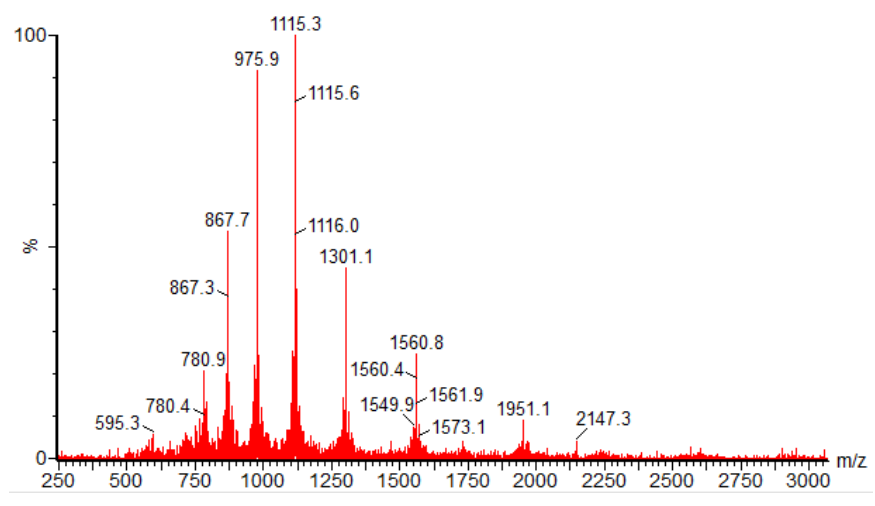

Figure 80. ESI-MS calcd. for $\mathrm{C}_{326} \mathrm{H}_{510} \mathrm{~N}_{92} \mathrm{O}_{128} \mathrm{~S}$, $[\mathrm{M}+4 \mathrm{H}]^{4+} \mathrm{m} / z=1950.6$, found 1951.1; $[\mathrm{M}+5 \mathrm{H}]^{5+} \mathrm{m} / z=$ 1560.7, found 1560.8; $[\mathrm{M}+6 \mathrm{H}]^{6+} \mathrm{m} / \mathrm{z}=1300.7$, found 1301.1; $[\mathrm{M}+7 \mathrm{H}]^{7+} \mathrm{m} / \mathrm{z}=1115.0$, found 1115.3; $[\mathrm{M}+8 \mathrm{H}]^{8+} m / z=975.8$, found $975.9 ;[\mathrm{M}+9 \mathrm{H}]^{9+} \mathrm{m} / z=867.5$, found $867.7 ;[\mathrm{M}+10 \mathrm{H}]^{10+} \mathrm{m} / z=780.8$, found 780.9 .

\section{Synthesis of peptide WM-6577101}

\subsection{Preparation of WM6577101b}

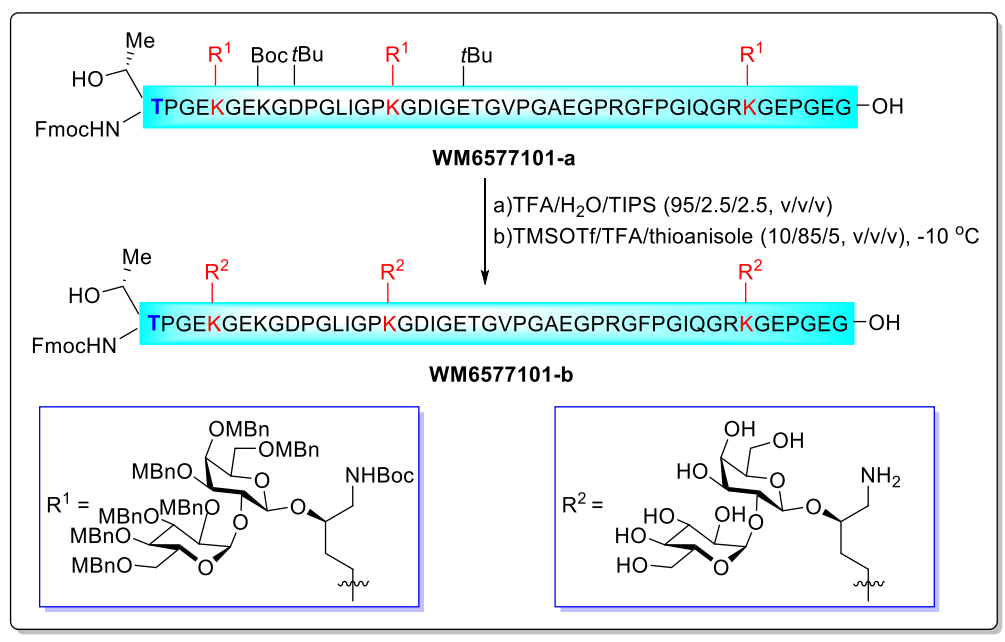


Peptide WM6577101-a was synthesized according to the general procedure A using 2-chlorotrityl chloride resin $(50 \mathrm{mg})$ by introducing the glycosylated 5-hydroxylysine building-block at desired positions. Upon completion of synthesis, the crude peptide was then deprotected and cleaved from the resin using $5 \mathrm{~mL}$ TFA/TIPS/ $\mathrm{H}_{2} \mathrm{O}(90: 5: 5, \mathrm{v} / \mathrm{v} / \mathrm{v})$ for $1 \mathrm{~h}$. The resin was filtered and the combined filtrate was stirred at $-10{ }^{\circ} \mathrm{C}$ in cooling bath for $10 \mathrm{~min}$. Then, thioanisole $625 \mu \mathrm{L}$ was added to the above solution and stirred for an additional $10 \mathrm{~min}$. TMSOTf $625 \mu \mathrm{L}$ was slowly added to the above solution and stirred at $-10{ }^{\circ} \mathrm{C}$ for $45 \mathrm{~min}$. The reaction solution was poured into cold $\left(-20^{\circ} \mathrm{C}\right)$ diethyl ether $(45 \mathrm{~mL})$, and the resulting suspension was centrifuged to give a white pellet. After decanting diethyl ether, the remaining solid was dissolved in $2 \mathrm{~mL} 50 \% \mathrm{CH}_{3} \mathrm{CN} / \mathrm{H}_{2} \mathrm{O}$ and $\mathrm{NH}_{4} \mathrm{HCO}_{3}$ solid was added until the solution $\mathrm{pH}$ became 7. The resulting solution was stirred at room temperature for $1 \mathrm{~h}$ and subjected to preparative HPLC purification $\left(20-50 \% \quad \mathrm{CH}_{3} \mathrm{CN} / \mathrm{H}_{2} \mathrm{O}\right.$ over $\left.45 \mathrm{~min}\right)$. Lyophilization afforded WM6577101-b (9.3 mg, 6.4\%) as a white powder.
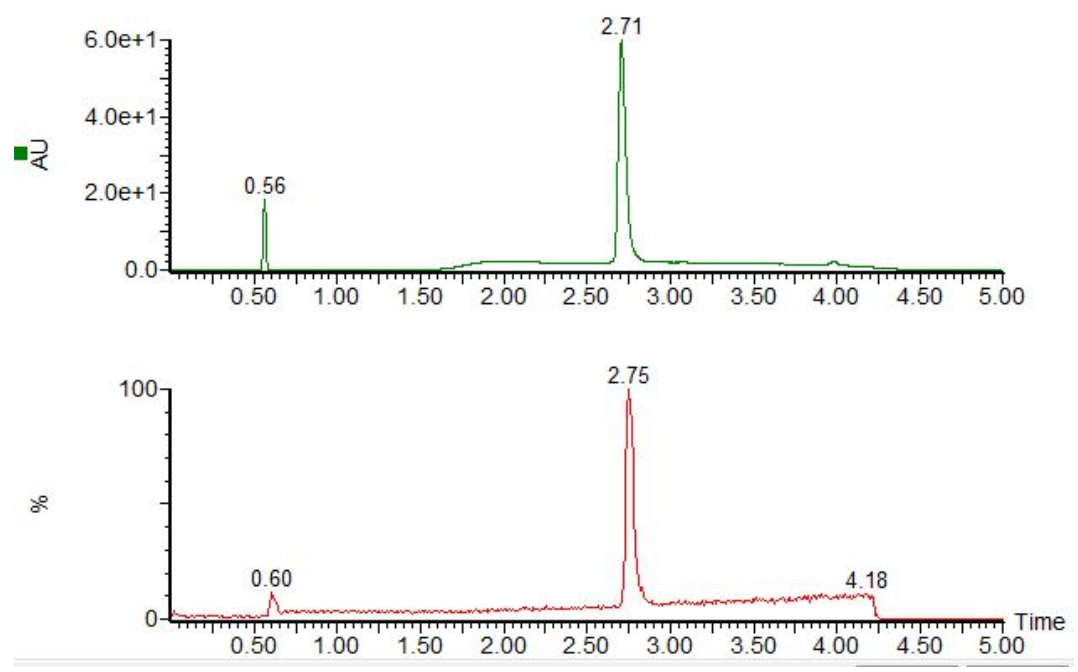

Figure 81. UV (190-400 nm) and MS (250-3000 m/z) traces from UPLC-MS analysis of purified WM6577101-b (gradient 5-95\% $\mathrm{CH}_{3} \mathrm{CN} / \mathrm{H}_{2} \mathrm{O}$ containing $0.1 \%$ TFA over 5 min at a flow rate of 0.4 $\mathrm{mL} / \mathrm{min})$. 


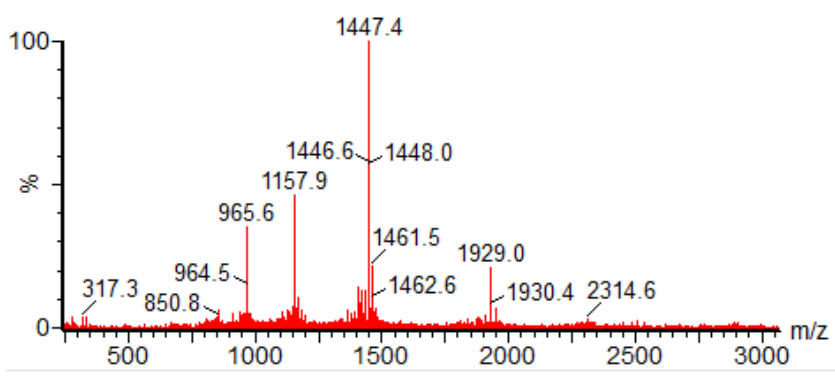

Figure 82. ESI-MS calcd. for $\mathrm{C}_{246} \mathrm{H}_{382} \mathrm{~N}_{58} \mathrm{O}_{102},[\mathrm{M}+3 \mathrm{H}]^{3+} \mathrm{m} / z=1929.0$, found 1929.9; $[\mathrm{M}+4 \mathrm{H}]^{4+} \mathrm{m} / z=$ 1447.0, found 1447.4; $[\mathrm{M}+5 \mathrm{H}]^{5+} \mathrm{m} / z=1157.8$, found 1157.9; $[\mathrm{M}+6 \mathrm{H}]^{6+} \mathrm{m} / z=965.0$, found 965.6.

\subsection{Preparation of WM6577101}

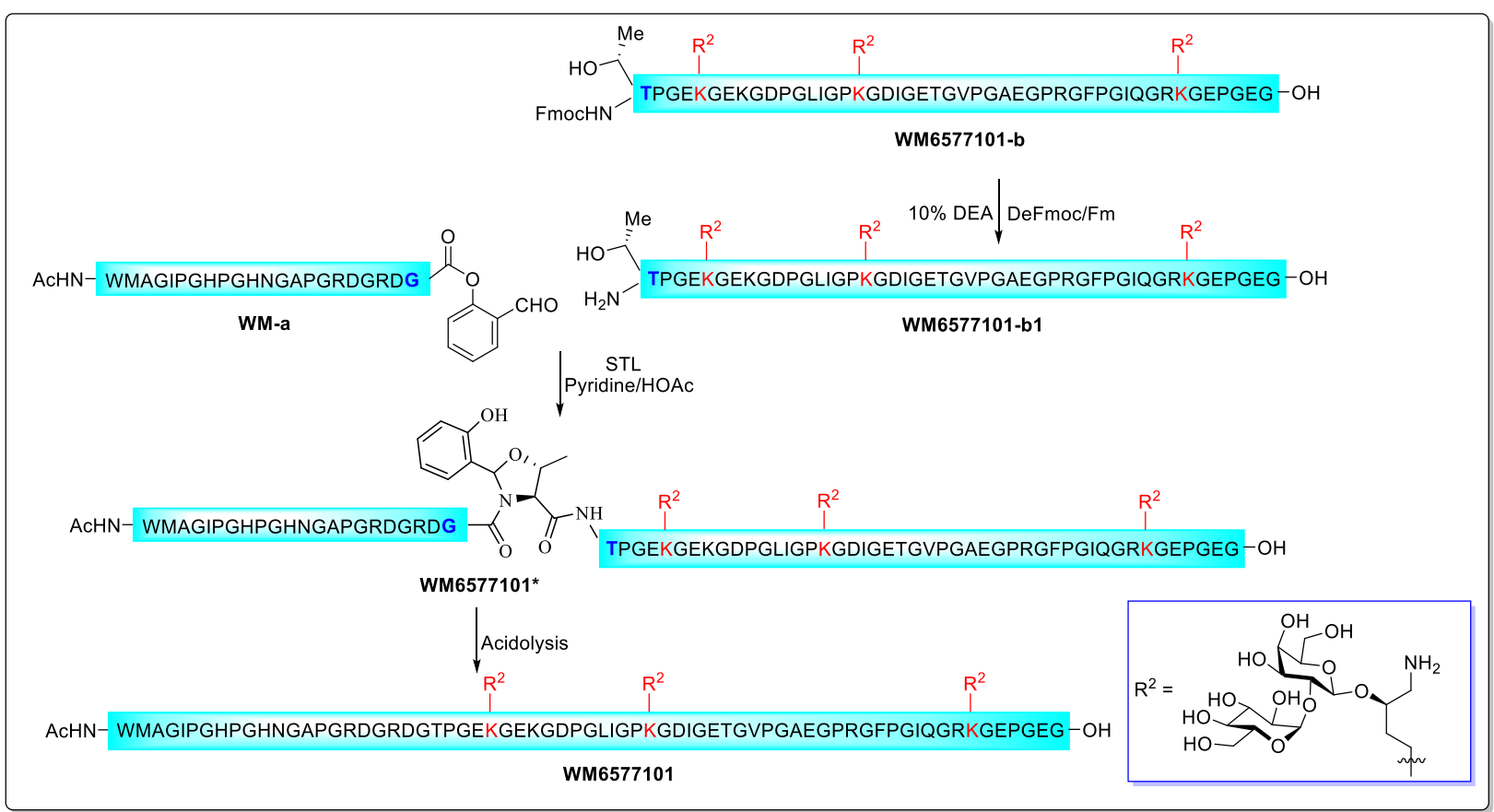

WM6577101-b $(9.3 \mathrm{mg}, 1.61 \mu \mathrm{mol})$ was dissolved in $250 \mu \mathrm{L} \mathrm{CH}_{3} \mathrm{CN} / \mathrm{H}_{2} \mathrm{O} /$ diethylamine $(4.5 / 4.5 / 1$, v/v/v) at room temperature and stirred at room temperature for $2 \mathrm{~h}$ to give product WM6577101-b1. The 
reaction mixture was diluted with $50 \% \mathrm{CH}_{3} \mathrm{CN} / \mathrm{H}_{2} \mathrm{O}(20 \mathrm{~mL})$ and subjected to lyophilization to afford WM6577101-b1 as a slightly yellow solid. This crude peptide was washed by diethyl ether. After that, WM6577101-b1 and WM-a $(3.8 \mathrm{mg}, 1.61 \mu \mathrm{mol})$ were dissolved in pyridine/acetic acid $(1 / 1$, mole/mole $)$ buffer at a concentration of $15 \mathrm{mM}$ at room temperature. The reaction mixture was stirred at room temperature for $4 \mathrm{~h}$ to give ligation intermediate $\mathbf{W M 6 5 7 7 1 0 1}$, and the solvent was then blown off under a stream of condensed $\mathrm{N}_{2}$. The residue was treated with $1 \mathrm{~mL} \mathrm{TFA} / \mathrm{H}_{2} \mathrm{O}(95 / 5, \mathrm{v} / \mathrm{v})$ for 20 min to obtain crude product WM6577101, and the TFA was blown off under a stream of condensed $\mathrm{N}_{2}$. The remaining residue was subjected to preparative HPLC purification $\left(10-35 \% \quad \mathrm{CH}_{3} \mathrm{CN} / \mathrm{H}_{2} \mathrm{O}\right.$ over $\left.45 \mathrm{~min}\right)$ and lyophilization to afford WM6577101 (2.6 $\mathrm{mg}, 20.7 \%)$ as a white powder.

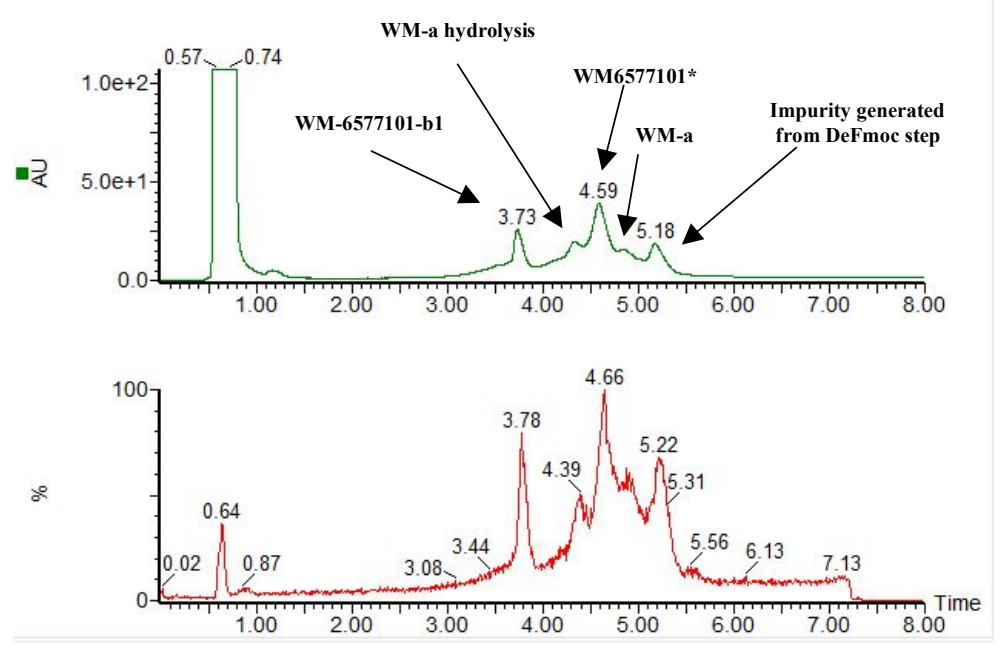

Figure 83. UV (190-400 nm) and MS (250-3000 m/z) traces from UPLC-MS analysis of STL between WM6577101-b1 and WM-a at $4 \mathrm{~h}$ (gradient 10-50\% $\mathrm{CH}_{3} \mathrm{CN} / \mathrm{H}_{2} \mathrm{O}$ containing $0.1 \%$ TFA over 8 min at a flow rate of $0.4 \mathrm{~mL} / \mathrm{min})$. 

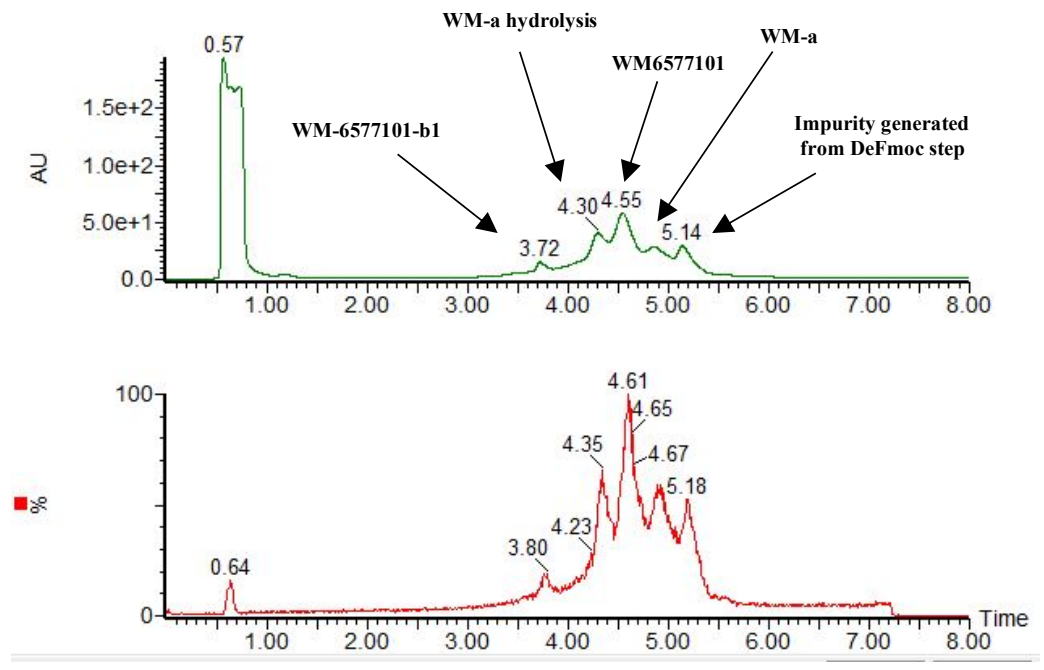

Figure 94. UV (190-400 nm) and MS (250-3000 m/z) traces from UPLC-MS analysis of STL acidolysis between WM6577101-b1 and WM-a at $4 \mathrm{~h}$ (gradient 10-50\% $\mathrm{CH}_{3} \mathrm{CN} / \mathrm{H}_{2} \mathrm{O}$ containing $0.1 \%$ TFA over 8 min at a flow rate of $0.4 \mathrm{~mL} / \mathrm{min}$ ).

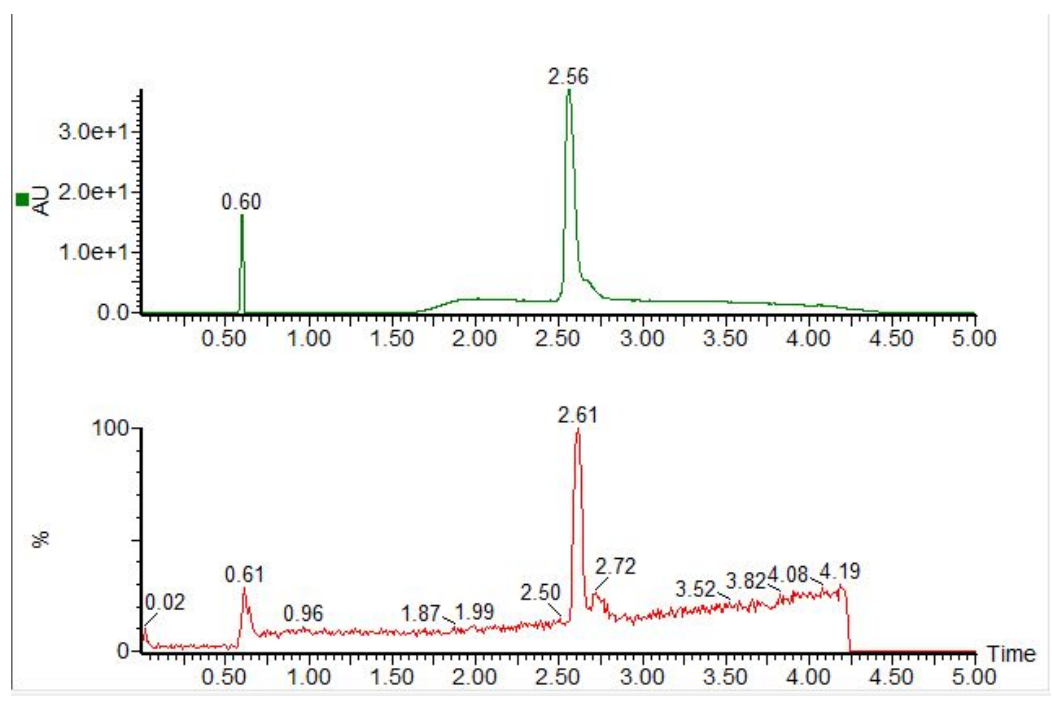

Figure 85. UV (190-400 nm) and MS $(250-3000 \mathrm{~m} / \mathrm{z})$ traces from UPLC-MS analysis of purified WM6577101 (gradient 5-95\% $\mathrm{CH}_{3} \mathrm{CN} / \mathrm{H}_{2} \mathrm{O}$ containing $0.1 \%$ TFA over 5 min at a flow rate of 0.4 $\mathrm{mL} / \mathrm{min})$. 


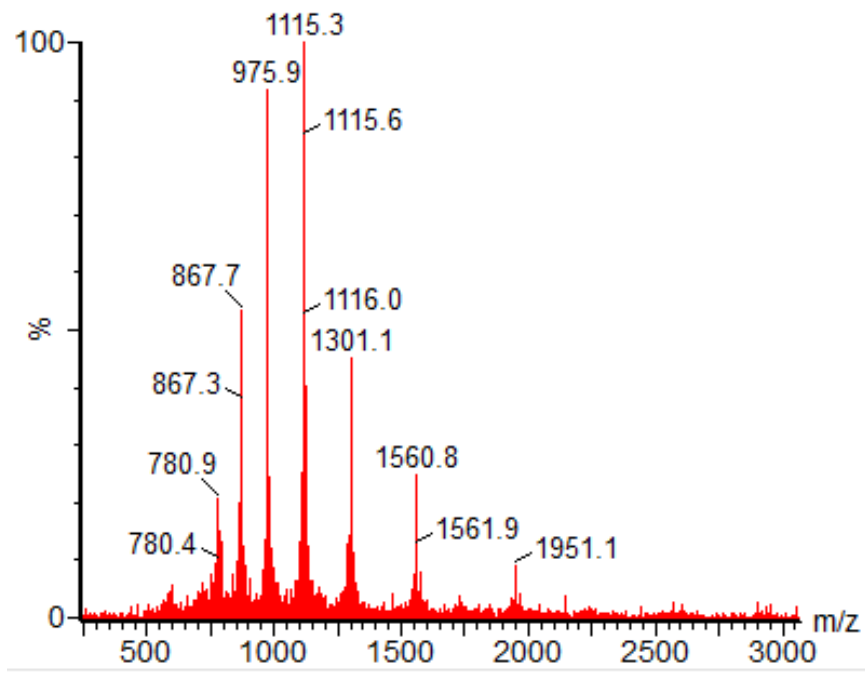

Figure 86. ESI-MS calcd. for $\mathrm{C}_{326} \mathrm{H}_{510} \mathrm{~N}_{92} \mathrm{O}_{128} \mathrm{~S}$, $[\mathrm{M}+4 \mathrm{H}]^{4+} \mathrm{m} / z=1950.6$, found 1951.1; $[\mathrm{M}+5 \mathrm{H}]^{5+} \mathrm{m} / z$ $=1560.7$, found 1560.8; $[\mathrm{M}+6 \mathrm{H}]^{6+} m / z=1300.7$, found 1301.1; $[\mathrm{M}+7 \mathrm{H}]^{7+} m / z=1115.0$, found 1115.3; $[\mathrm{M}+8 \mathrm{H}]^{8+} m / z=975.8$, found $975.9 ;[\mathrm{M}+9 \mathrm{H}]^{9+} \mathrm{m} / z=867.5$, found $867.7 ;[\mathrm{M}+10 \mathrm{H}]^{10+} \mathrm{m} / \mathrm{z}=780.8$, found 780.9

\section{Synthesis of peptide WM-6877101}

\subsection{Preparation of WM6877101a}

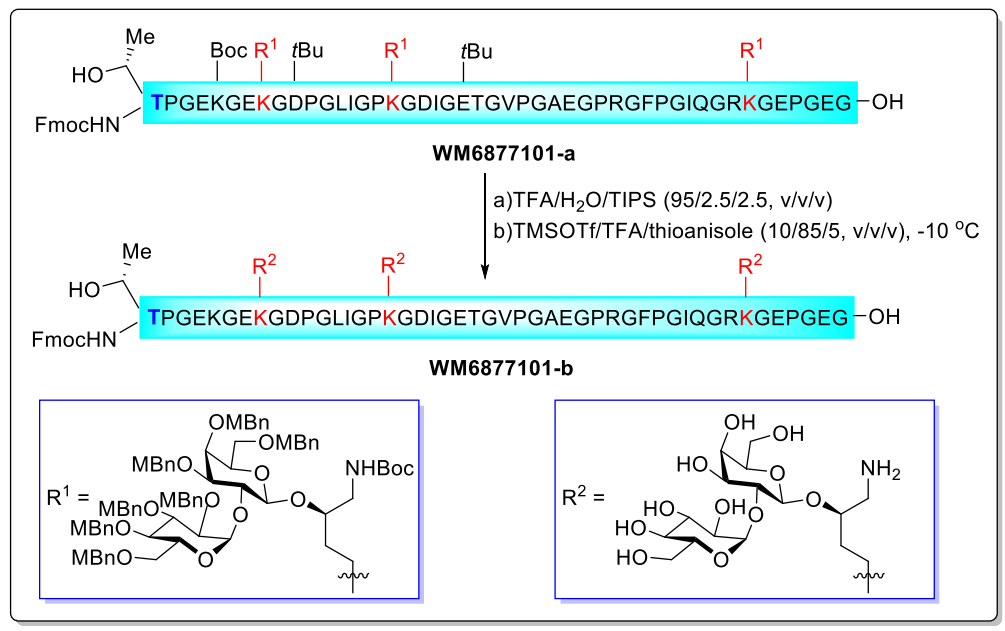


Peptide WM6877101-a was synthesized according to the general procedure A using 2-chlorotrityl chloride resin $(50 \mathrm{mg})$ by introducing the glycosylated 5-hydroxylysine building-block at desired positions. Upon completion of synthesis, the crude peptide was then deprotected and cleaved from the resin using $5 \mathrm{~mL}$ TFA/TIPS/H2O (90:5:5, v/v/v) for $1 \mathrm{~h}$. The resin was filtered and the combined filtrate was stirred at $-10{ }^{\circ} \mathrm{C}$ in cooling bath for $10 \mathrm{~min}$. Then, thioanisole $625 \mu \mathrm{L}$ was added to the above solution and stirred for an additional $10 \mathrm{~min}$. TMSOTf $625 \mu \mathrm{L}$ was slowly added to the above solution and stirred at $-10{ }^{\circ} \mathrm{C}$ for $45 \mathrm{~min}$. The reaction solution was poured into cold $\left(-20^{\circ} \mathrm{C}\right)$ diethyl ether $(45 \mathrm{~mL})$, and the resulting suspension was centrifuged to give a white pellet. After decanting diethyl ether, the remaining solid was dissolved in $2 \mathrm{~mL} 50 \% \mathrm{CH}_{3} \mathrm{CN} / \mathrm{H}_{2} \mathrm{O}$ and $\mathrm{NH}_{4} \mathrm{HCO}_{3}$ solid was added until the solution $\mathrm{pH}$ became 7. The resulting solution was stirred at room temperature for $1 \mathrm{~h}$ and subjected to preparative HPLC purification $\left(20-50 \% \quad \mathrm{CH}_{3} \mathrm{CN} / \mathrm{H}_{2} \mathrm{O}\right.$ over $\left.45 \mathrm{~min}\right)$. Lyophilization afforded WM6877101-b $(8.8 \mathrm{mg}, 6.1 \%)$ as a white powder.

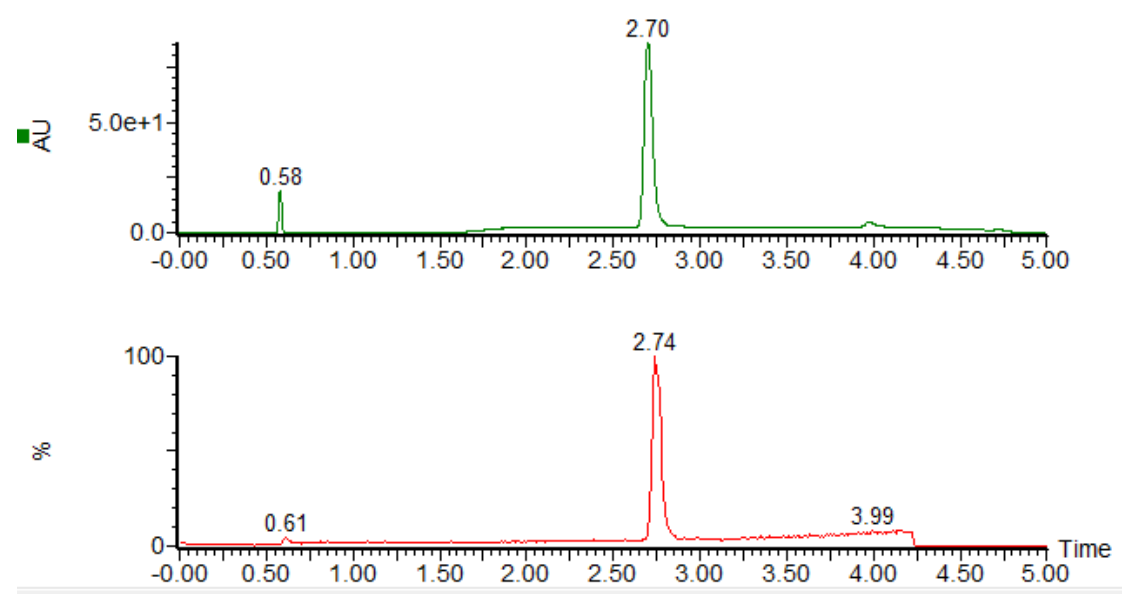

Figure 87. UV (190-400 nm) and MS (250-3000 m/z) traces from UPLC-MS analysis of purified WM6877101-b (gradient 5-95\% $\mathrm{CH}_{3} \mathrm{CN} / \mathrm{H}_{2} \mathrm{O}$ containing $0.1 \%$ TFA over 5 min at a flow rate of 0.4 $\mathrm{mL} / \mathrm{min})$. 


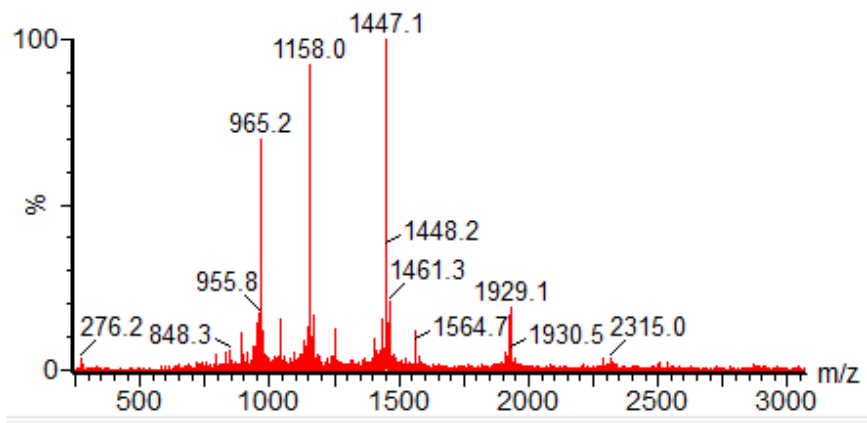

Figure 88. ESI-MS calcd. for $\mathrm{C}_{246} \mathrm{H}_{382} \mathrm{~N}_{58} \mathrm{O}_{102}$, $[\mathrm{M}+3 \mathrm{H}]^{3+} \mathrm{m} / z=1929.0$, found 1929.1; $[\mathrm{M}+4 \mathrm{H}]^{4+} \mathrm{m} / z=$ 1447.0, found 1447.1; $[\mathrm{M}+5 \mathrm{H}]^{5+} \mathrm{m} / z=1157.8$, found 1158.0; $[\mathrm{M}+6 \mathrm{H}]^{6+} \mathrm{m} / z=965.0$, found 965.2.

\subsection{Preparation of WM6877101}

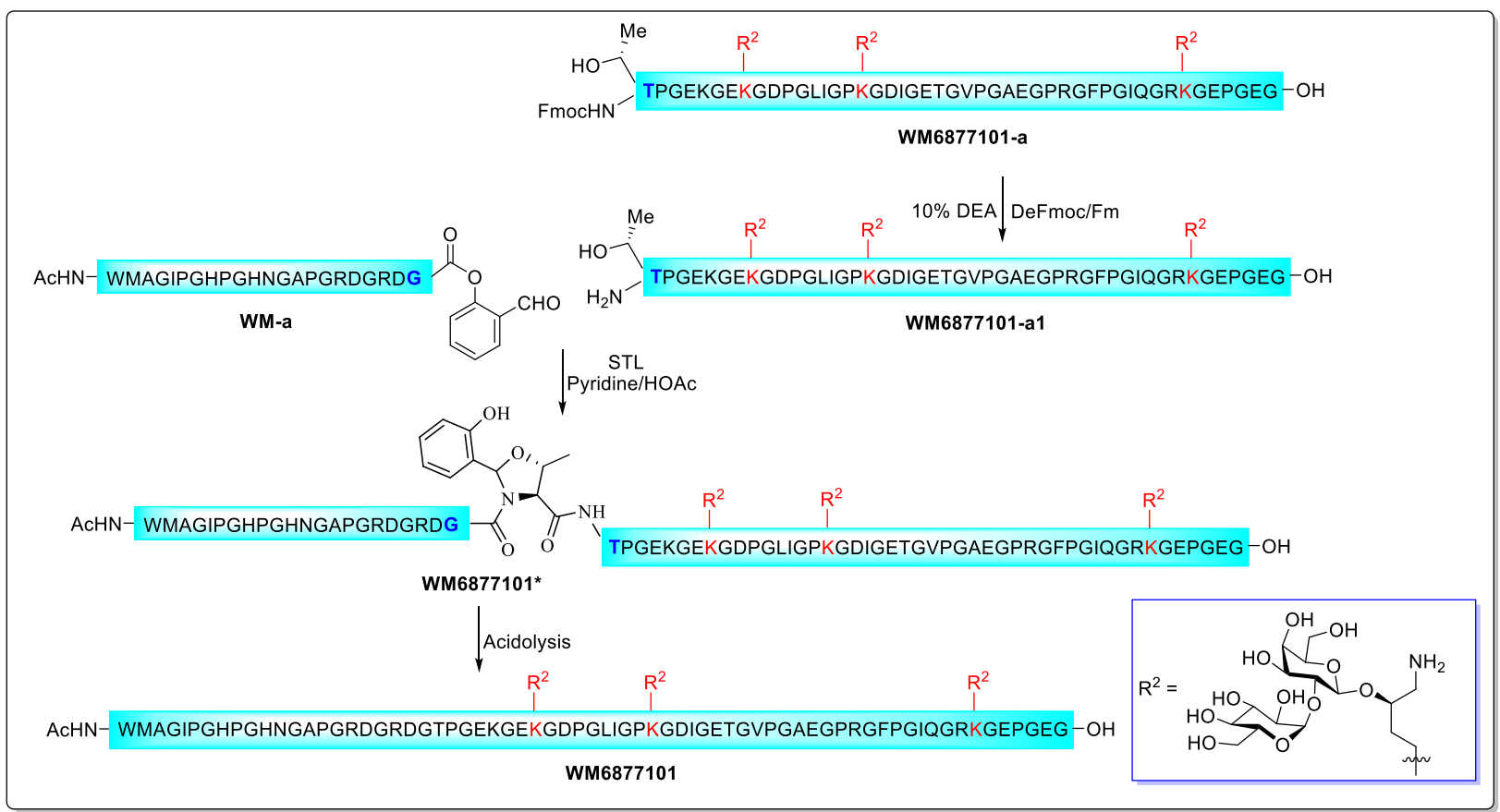

WM6877101-a (8.8 mg, $1.52 \mu \mathrm{mol})$ was dissolved in $250 \mu \mathrm{L} \mathrm{CH}_{3} \mathrm{CN} / \mathrm{H}_{2} \mathrm{O} /$ diethylamine $(4.5 / 4.5 / 1$, v/v/v) at room temperature and stirred at room temperature for $2 \mathrm{~h}$ to give product WM6877101-b1. The reaction mixture was diluted with $50 \% \mathrm{CH}_{3} \mathrm{CN} / \mathrm{H}_{2} \mathrm{O}(20 \mathrm{~mL})$ and subjected to lyophilization to afford 
WM6877101-b1 as a slightly yellow solid. This crude peptide was washed by diethyl ether. After that, WM6877101-b1 and WM-a (3.6 mg, $1.52 \mu \mathrm{mol})$ were dissolved in pyridine/acetic acid (1/1, mole/mole) buffer at a concentration of $15 \mathrm{mM}$ at room temperature. The reaction mixture was stirred at room temperature for $4 \mathrm{~h}$ to give ligation intermediate $\mathbf{W M 6 8 7 7 1 0 1}{ }^{*}$, and the solvent was then blown off under a stream of condensed $\mathrm{N}_{2}$. The residue was treated with $1 \mathrm{~mL} \mathrm{TFA} / \mathrm{H}_{2} \mathrm{O}(95 / 5, \mathrm{v} / \mathrm{v})$ for 20 min to obtain crude product WM6877101, and the TFA was blown off under a stream of condensed $\mathrm{N}_{2}$. The remaining residue was subjected to preparative HPLC purification $\left(10-35 \% \quad \mathrm{CH}_{3} \mathrm{CN} / \mathrm{H}_{2} \mathrm{O}\right.$ over 45 min) and lyophilization to afford WM6877101 (3.0 mg, 25.3\%) as a white powder.
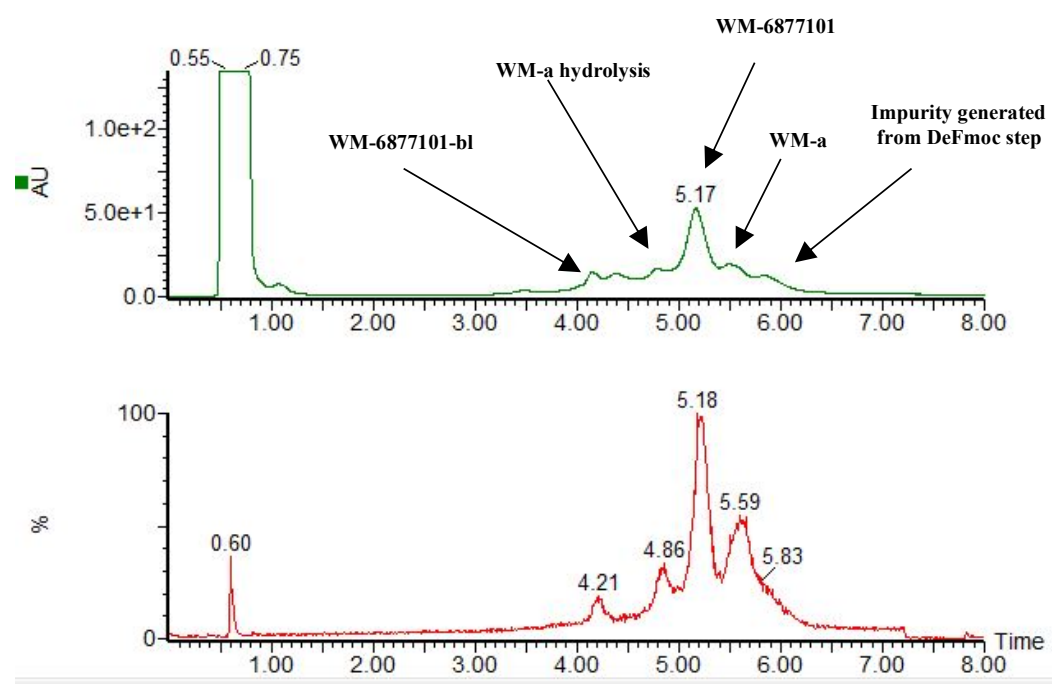

Figure 89. UV (190-400 nm) and MS (250-3000 m/z) traces from UPLC-MS analysis of STL between WM6877101-b1 and WM-a at $4 \mathrm{~h}$ (gradient $10-50 \% \mathrm{CH}_{3} \mathrm{CN} / \mathrm{H}_{2} \mathrm{O}$ containing $0.1 \%$ TFA over 8 min at a flow rate of $0.4 \mathrm{~mL} / \mathrm{min}$ ). 

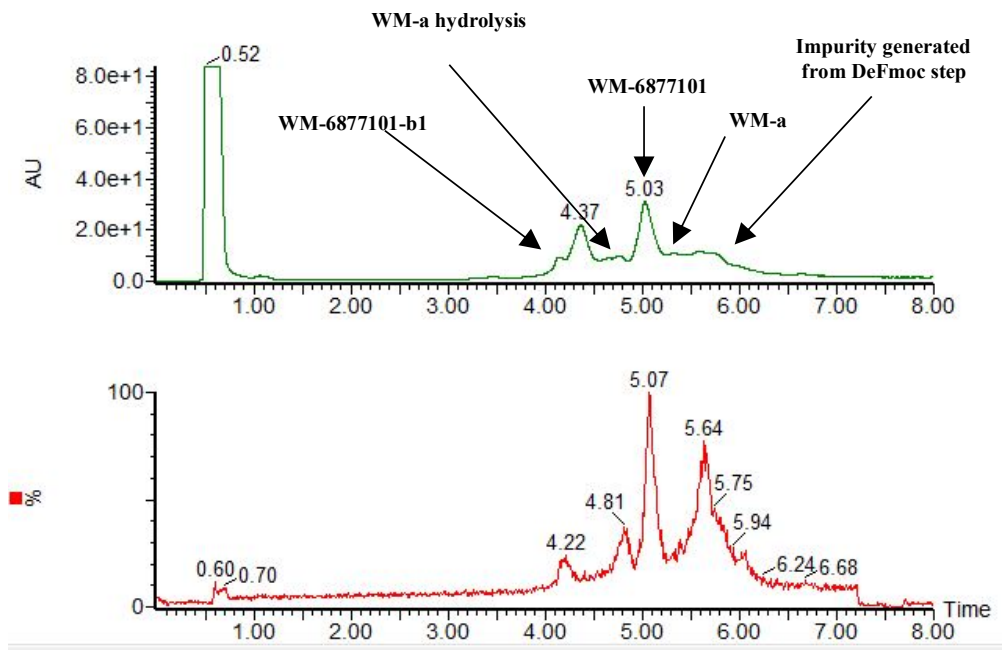

Figure 90. UV (190-400 nm) and MS (250-3000 m/z) traces from UPLC-MS analysis of STL acidolysis between WM6877101-b1 and WM-a at $4 \mathrm{~h}$ (gradient 10-35\% $\mathrm{CH}_{3} \mathrm{CN} / \mathrm{H}_{2} \mathrm{O}$ containing $0.1 \%$ TFA over 8 min at a flow rate of $0.4 \mathrm{~mL} / \mathrm{min}$ ).

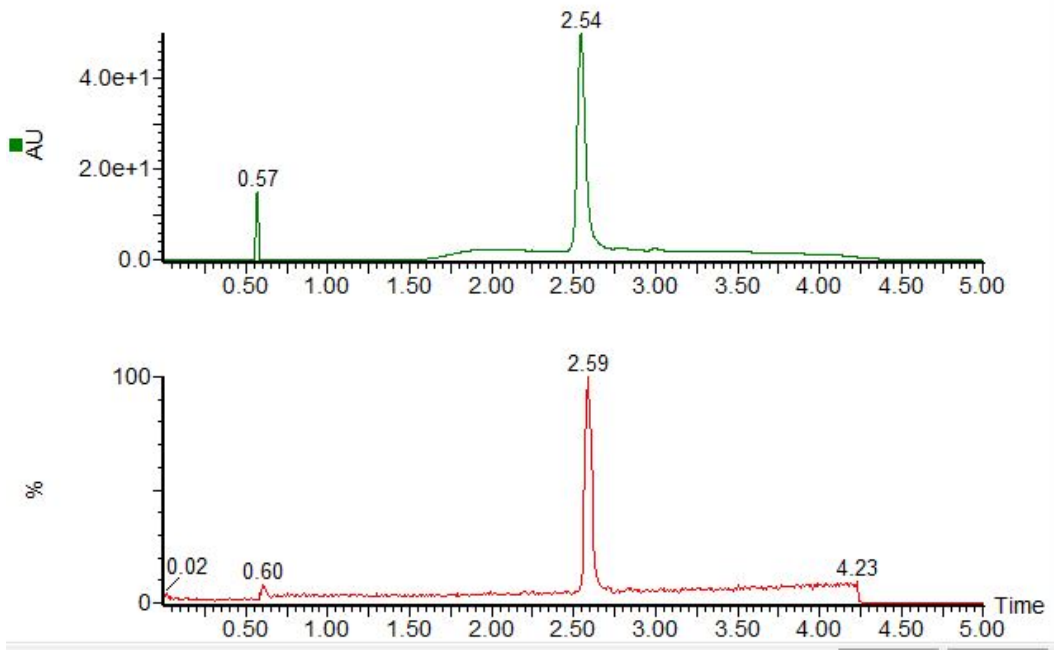

Figure 91. UV (190-400 $\mathrm{nm})$ and MS $(250-3000 \mathrm{~m} / \mathrm{z})$ traces from UPLC-MS analysis of purified WM6877101 (gradient 5-95\% $\mathrm{CH}_{3} \mathrm{CN} / \mathrm{H}_{2} \mathrm{O}$ containing $0.1 \%$ TFA over $5 \mathrm{~min}$ at a flow rate of 0.4 $\mathrm{mL} / \mathrm{min})$. 


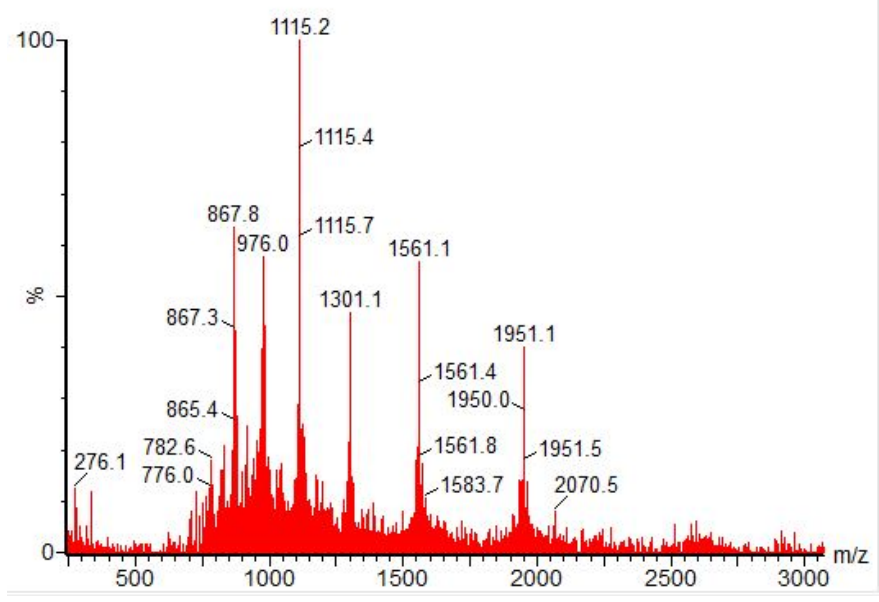

Figure 92. ESI-MS calcd. for $\mathrm{C}_{326} \mathrm{H}_{510} \mathrm{~N}_{92} \mathrm{O}_{128} \mathrm{~S}$, $[\mathrm{M}+4 \mathrm{H}]^{4+} \mathrm{m} / \mathrm{z}=1950.6$, found 1951.1; $[\mathrm{M}+5 \mathrm{H}]^{5+} \mathrm{m} / z=$ 1560.7, found 1561.1; $[\mathrm{M}+6 \mathrm{H}]^{6+} m / z=1300.7$, found 1301.1; $[\mathrm{M}+7 \mathrm{H}]^{7+} \mathrm{m} / z=1115.0$, found 1115.2; $[\mathrm{M}+8 \mathrm{H}]^{8+} m / z=975.8$, found $976.0 ;[\mathrm{M}+9 \mathrm{H}]^{9+} m / z=867.5$, found 867.8 .

\section{Synthesis of peptide WM-656877101}

\subsection{Preparation of WM656877101b}

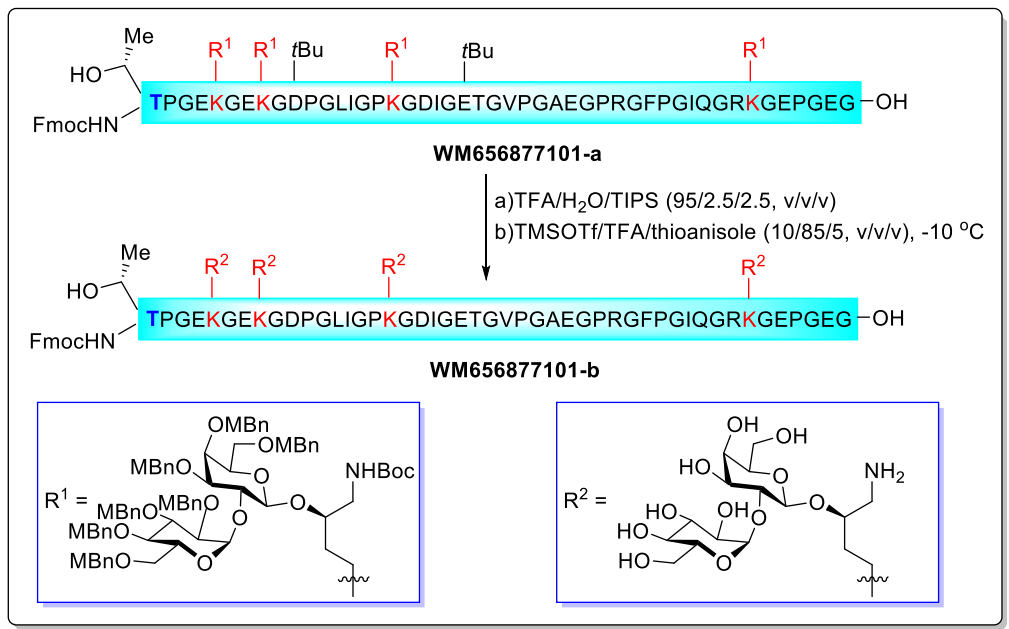


Peptide WM656877101-a was synthesized according to the general procedure A using 2-chlorotrityl chloride resin $(50 \mathrm{mg})$ by introducing the glycosylated 5-hydroxylysine building-block at desired positions. Upon completion of synthesis, the crude peptide was then deprotected and cleaved from the resin using $5 \mathrm{~mL}$ TFA/TIPS/ $\mathrm{H}_{2} \mathrm{O}(90: 5: 5, \mathrm{v} / \mathrm{v} / \mathrm{v})$ for $1 \mathrm{~h}$. The resin was filtered and the combined filtrate was stirred at $-10{ }^{\circ} \mathrm{C}$ cooling bath for $10 \mathrm{~min}$. Then, thioanisole $625 \mu \mathrm{L}$ was added to the above solution and stirred for an additional $10 \mathrm{~min}$. TMSOTf $625 \mu \mathrm{L}$ was slowly added to the above solution and stirred at $-10{ }^{\circ} \mathrm{C}$ for $45 \mathrm{~min}$. The reaction solution was poured into cold $\left(-20^{\circ} \mathrm{C}\right)$ diethyl ether $(45 \mathrm{~mL})$, and the resulting suspension was centrifuged to give a white pellet. After decanting diethyl ether, the remaining solid was dissolved in $2 \mathrm{~mL} 50 \% \mathrm{CH}_{3} \mathrm{CN} / \mathrm{H}_{2} \mathrm{O}$ and $\mathrm{NH}_{4} \mathrm{HCO}_{3}$ solid was added until the solution $\mathrm{pH}$ became 7. The resulting solution was stirred at room temperature for $1 \mathrm{~h}$ and subjected to preparative HPLC purification (20-50\% $\mathrm{CH}_{3} \mathrm{CN} / \mathrm{H}_{2} \mathrm{O}$ over $45 \mathrm{~min}$ ). Lyophilization afforded WM656877101-b (5.6 $\mathrm{mg}, 3.6 \%)$ as a white powder.
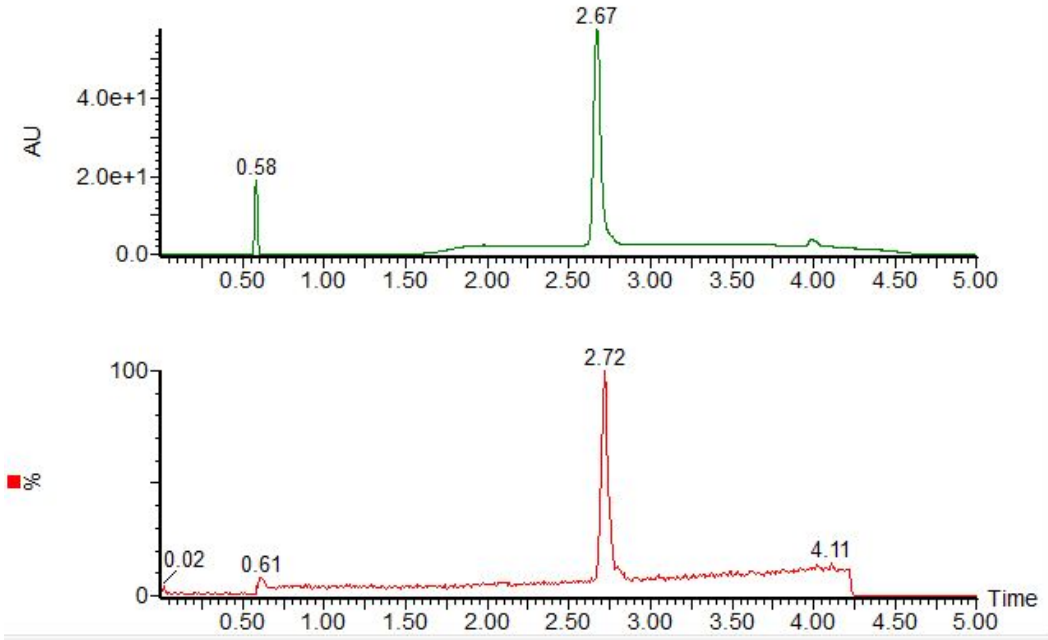

Figure 93. UV (190-400 $\mathrm{nm})$ and MS $(250-3000 \mathrm{~m} / \mathrm{z})$ traces from UPLC-MS analysis of purified WM656877101-b (gradient 5-95\% $\mathrm{CH}_{3} \mathrm{CN} / \mathrm{H}_{2} \mathrm{O}$ containing $0.1 \%$ TFA over 5 min at a flow rate of 0.4 $\mathrm{mL} / \mathrm{min})$. 


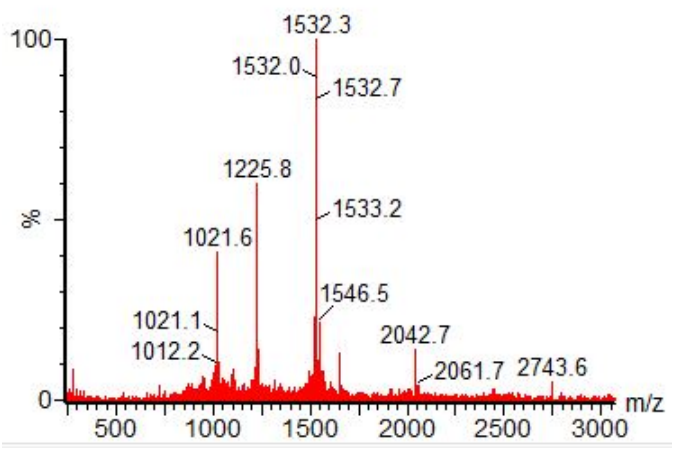

Figure 94. ESI-MS calcd. for $\mathrm{C}_{258} \mathrm{H}_{402} \mathrm{~N}_{58} \mathrm{O}_{113},[\mathrm{M}+3 \mathrm{H}]^{3+} \mathrm{m} / z=2042.5$, found 2042.7; $[\mathrm{M}+4 \mathrm{H}]^{4+} \mathrm{m} / z=$ 1532.1, found 1532.3; $[\mathrm{M}+5 \mathrm{H}]^{5+} \mathrm{m} / z=1225.9$, found 1225.8; $[\mathrm{M}+6 \mathrm{H}]^{6+} \mathrm{m} / z=1021.7$, found 1021.6.

\subsection{Preparation of WM656877101}

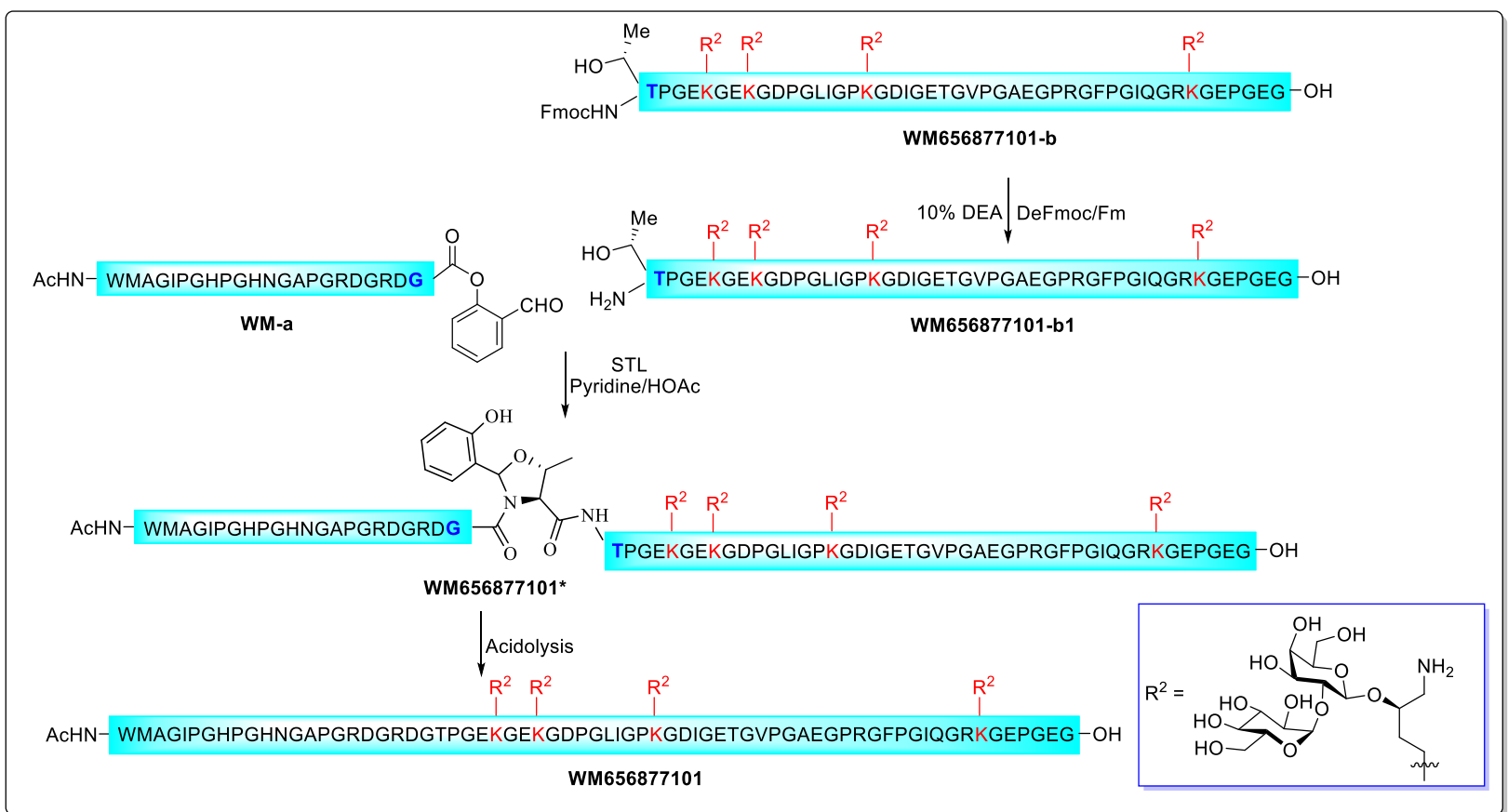

WM656877101-b $(5.6 \mathrm{mg}, 0.91 \mu \mathrm{mol})$ was dissolved in $250 \mu \mathrm{L} \mathrm{CH}_{3} \mathrm{CN} / \mathrm{H}_{2} \mathrm{O} /$ diethylamine $(4.5 / 4.5 / 1$, $\mathrm{v} / \mathrm{v} / \mathrm{v}$ ) at room temperature and stirred at room temperature for $2 \mathrm{~h}$ to give product WM656877101-b1. 
The reaction mixture was diluted with $50 \% \mathrm{CH}_{3} \mathrm{CN} / \mathrm{H}_{2} \mathrm{O}(20 \mathrm{~mL})$ and subjected to lyophilization to afford WM656877101-b1 as a slightly yellow solid. This crude peptide was washed by diethyl ether. After that, WM656877101-b1 and WM-a $(3.1 \mathrm{mg}, 1.34 \mu \mathrm{mol})$ were dissolved in pyridine/acetic acid (1/1, mole/mole) buffer at a concentration of $15 \mathrm{mM}$ at room temperature. The reaction mixture was stirred at room temperature for $4 \mathrm{~h}$ to give ligation intermediate WM656877101*, and the solvent was then blown off under a stream of condensed $\mathrm{N}_{2}$. The residue was treated with $1 \mathrm{~mL} \mathrm{TFA} / \mathrm{H}_{2} \mathrm{O}(95 / 5, \mathrm{v} / \mathrm{v})$ for $20 \mathrm{~min}$ to obtain crude product WM656877101, and the TFA was blown off tunder a stream of condensed $\mathrm{N}_{2}$. The remaining residue was subjected to preparative HPLC purification (10-35\% $\mathrm{CH}_{3} \mathrm{CN} / \mathrm{H}_{2} \mathrm{O}$ over $\left.45 \mathrm{~min}\right)$ and lyophilization to afford WM656877101 (1.2 $\mathrm{mg}, 16.2 \%)$ as a white powder.
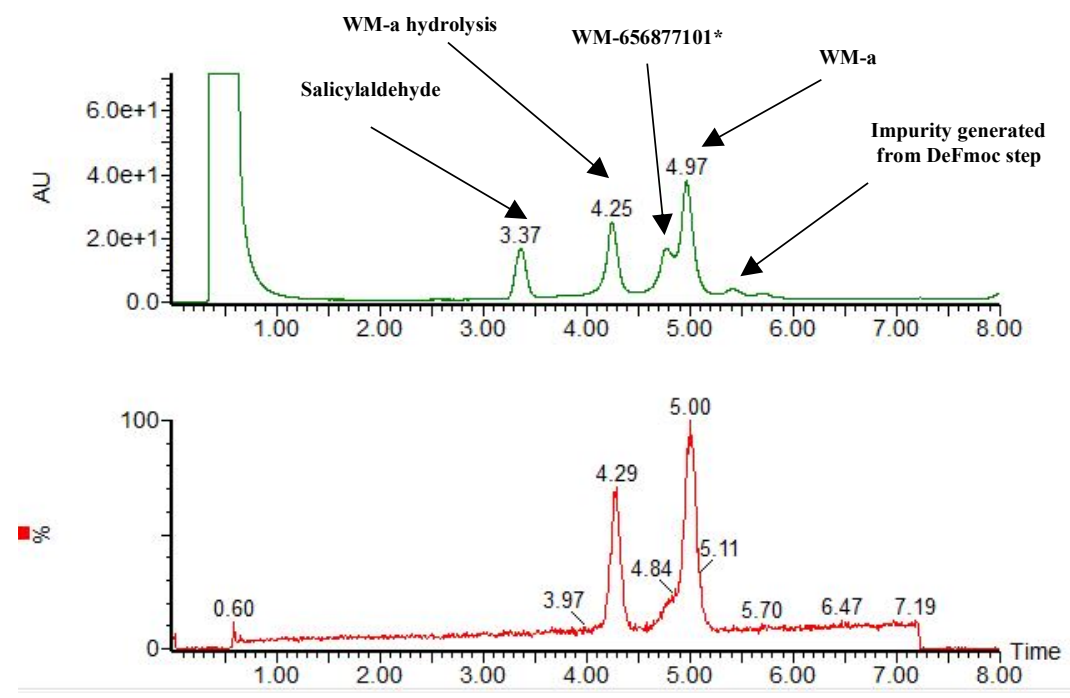

Figure 95. UV (190-400 nm) and MS (250-3000 m/z) traces from UPLC-MS analysis of STL between WM656877101-b1 and WM-a at $4 \mathrm{~h}$ (gradient $10-40 \% \mathrm{CH}_{3} \mathrm{CN} / \mathrm{H}_{2} \mathrm{O}$ containing $0.1 \%$ TFA over 8 min at a flow rate of $0.4 \mathrm{~mL} / \mathrm{min}$ ). 

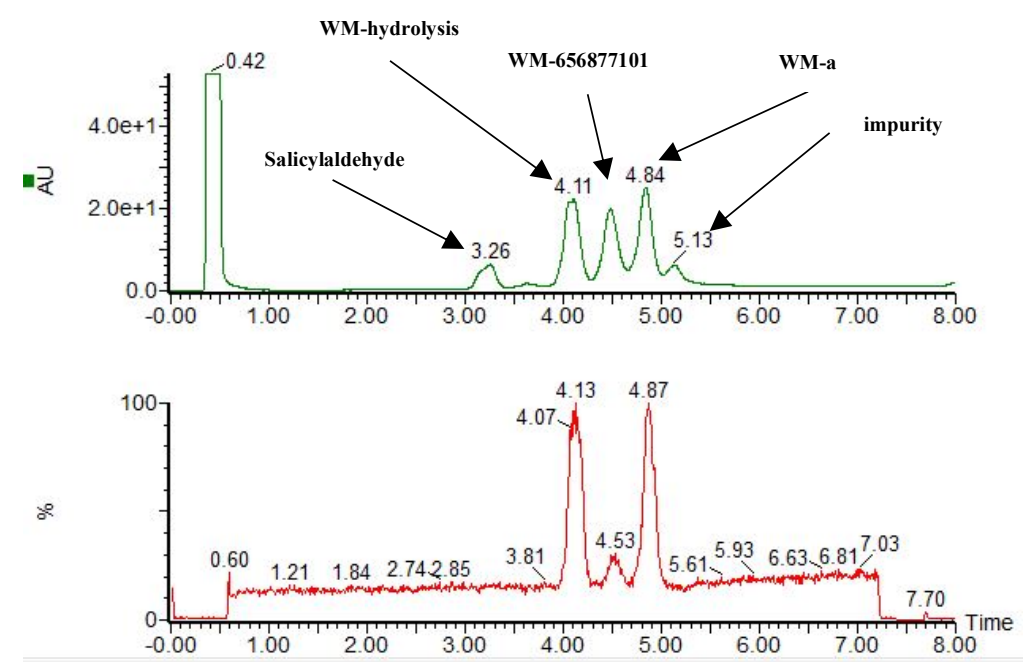

Figure 96. UV (190-400 nm) and MS (250-3000 m/z) traces from UPLC-MS analysis of STL acidolysis between WM656877101-b1 and WM-a at $4 \mathrm{~h}$ (gradient 10-50\% $\mathrm{CH}_{3} \mathrm{CN} / \mathrm{H}_{2} \mathrm{O}$ containing $0.1 \%$ TFA over $8 \mathrm{~min}$ at a flow rate of $0.4 \mathrm{~mL} / \mathrm{min})$.
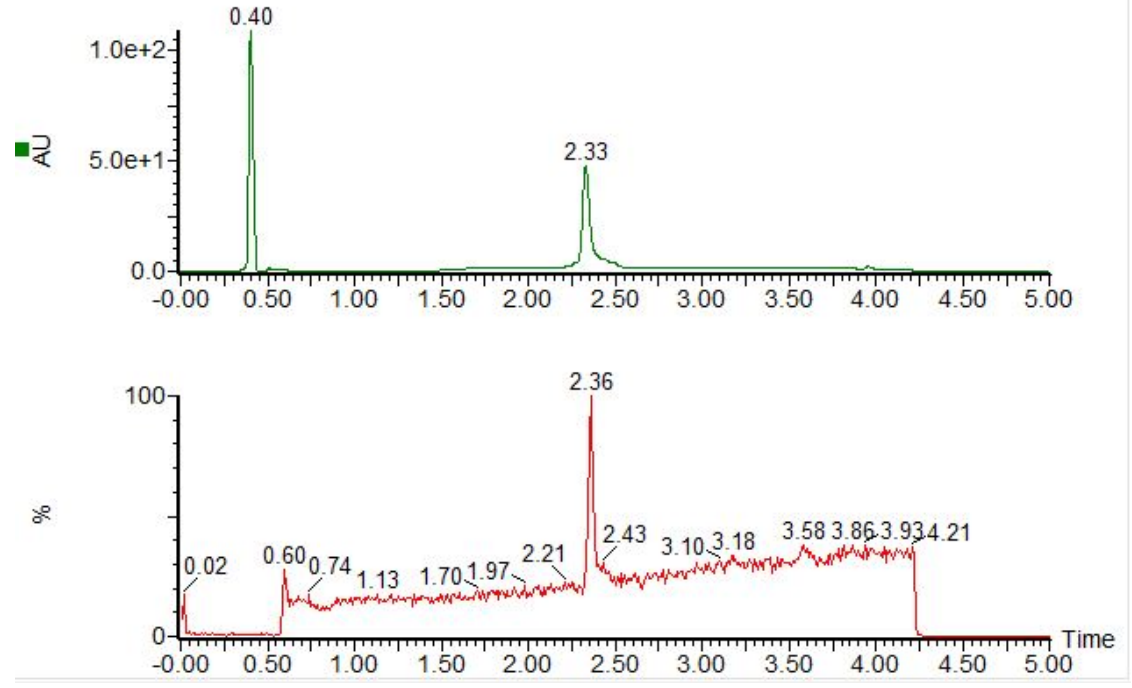

Figure 97. UV (190-400 $\mathrm{nm})$ and MS $(250-3000 \mathrm{~m} / \mathrm{z})$ traces from UPLC-MS analysis of purified WM656877101 (gradient 5-95\% $\mathrm{CH}_{3} \mathrm{CN} / \mathrm{H}_{2} \mathrm{O}$ containing $0.1 \%$ TFA over 5 min at a flow rate of 0.4 $\mathrm{mL} / \mathrm{min})$. 


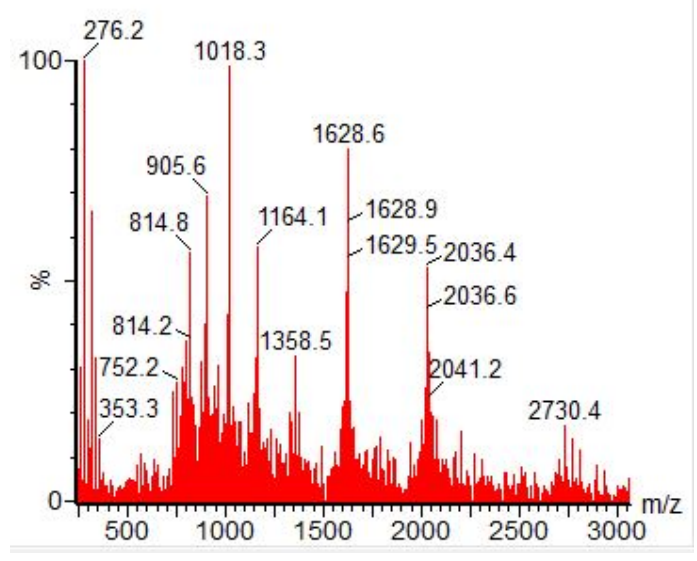

Figure 98. ESI-MS calcd. for $\mathrm{C}_{338} \mathrm{H}_{530} \mathrm{~N}_{92} \mathrm{O}_{139} \mathrm{~S}$, $[\mathrm{M}+4 \mathrm{H}]^{4+} \mathrm{m} / z=2035.6$, found 2036.4; $[\mathrm{M}+5 \mathrm{H}]^{5+} m / z=$ 1628.7, found 1628.6; $[\mathrm{M}+6 \mathrm{H}]^{6+} m / z=1357.4$, found 1358.5; $[\mathrm{M}+7 \mathrm{H}]^{7+} \mathrm{m} / z=1163.6$, found 1164.1 $[\mathrm{M}+8 \mathrm{H}]^{8+} m / z=1018.3$, found 1018.3; $[\mathrm{M}+9 \mathrm{H}]^{9+} \mathrm{m} / \mathrm{z}=905.3$, found 905.6; $[\mathrm{M}+10 \mathrm{H}]^{10+} \mathrm{m} / \mathrm{z}=814.9$, found 814.8 . 
VII. ${ }^{1} \mathrm{H}$ and ${ }^{13} \mathrm{C}$ NMR spectra
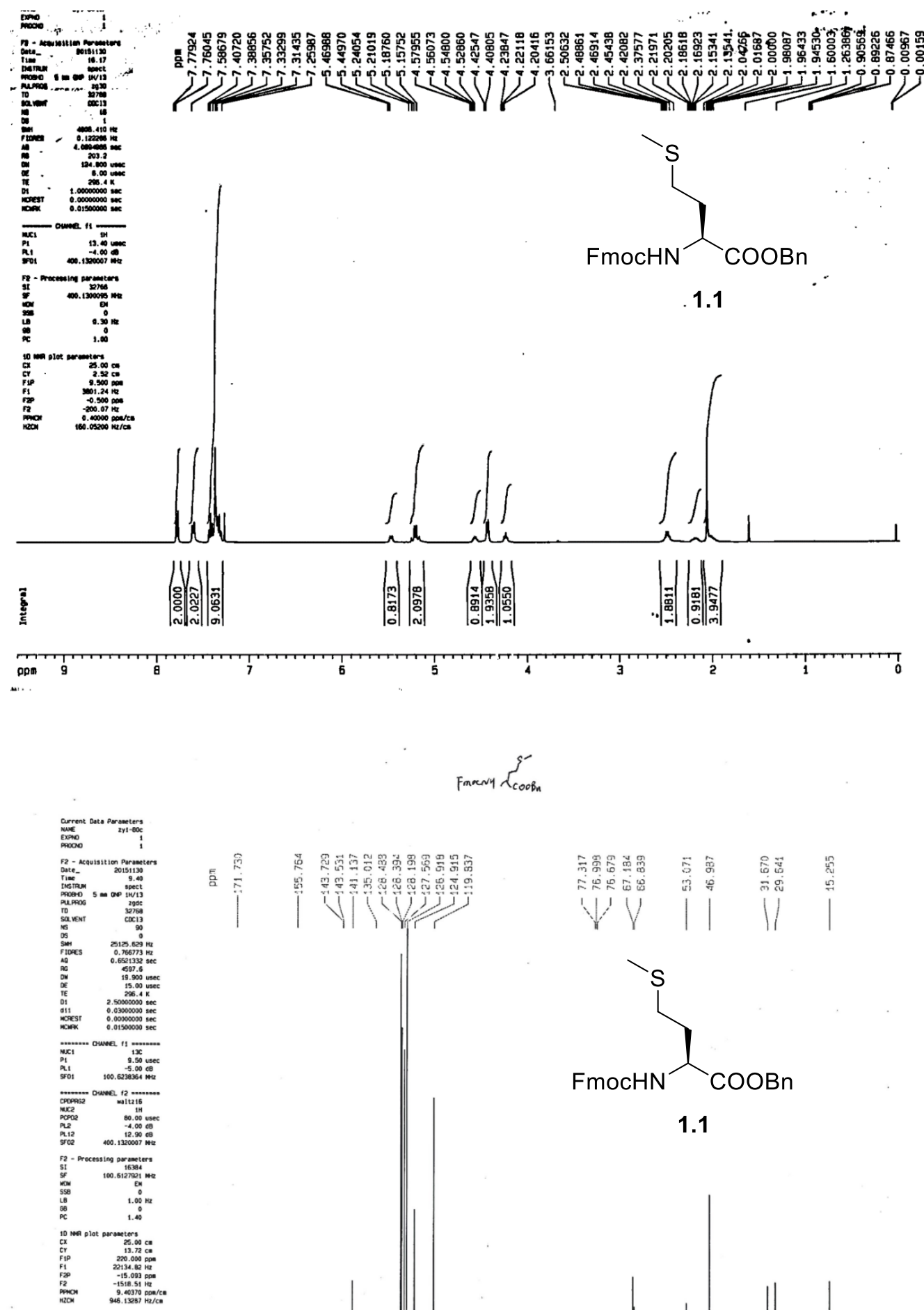

1.1

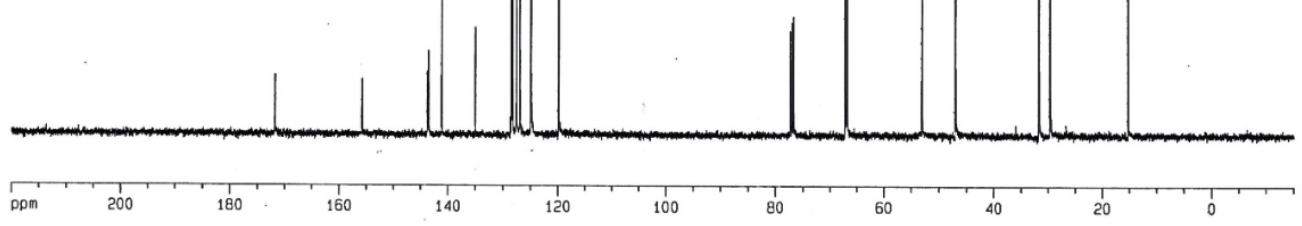



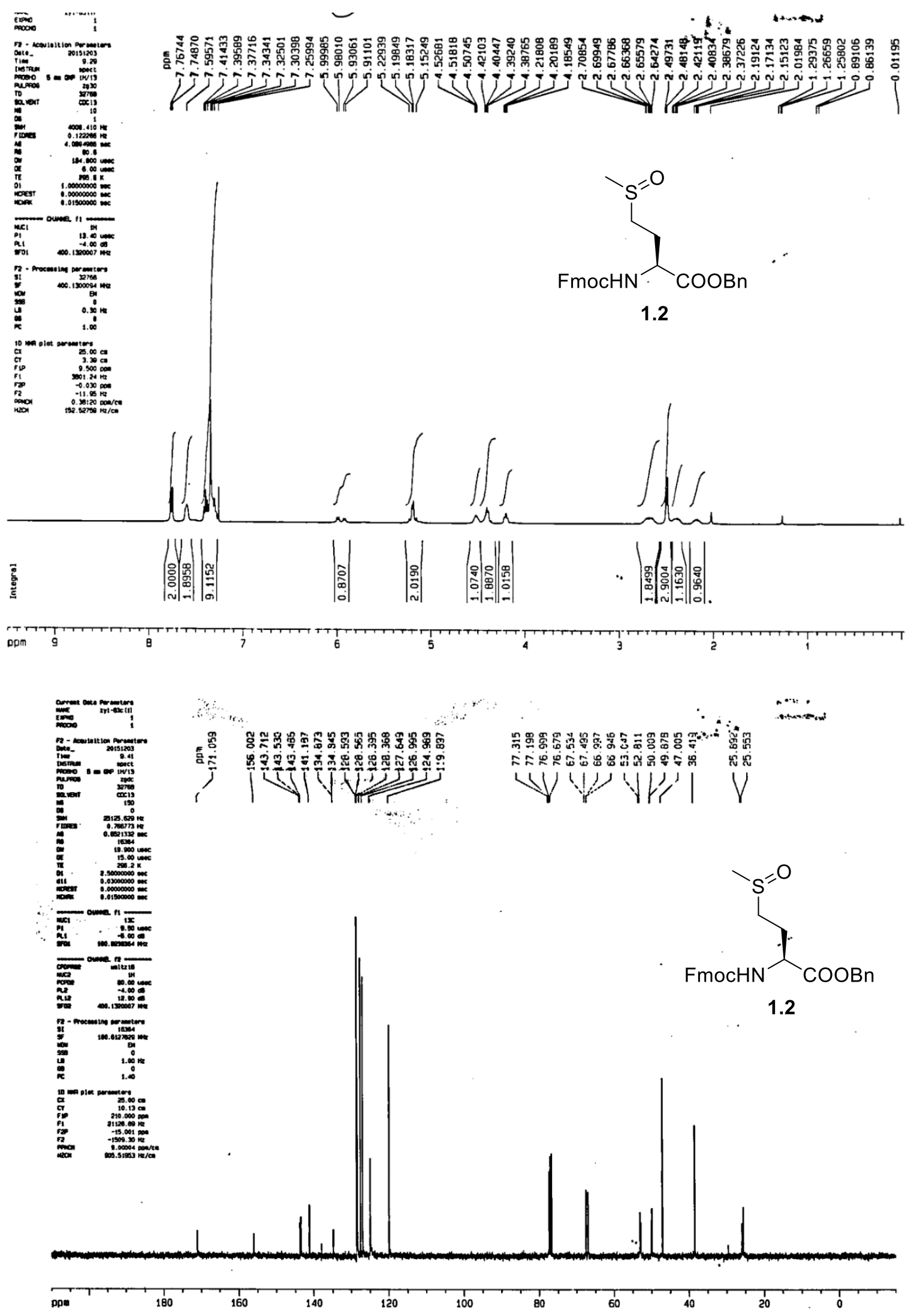


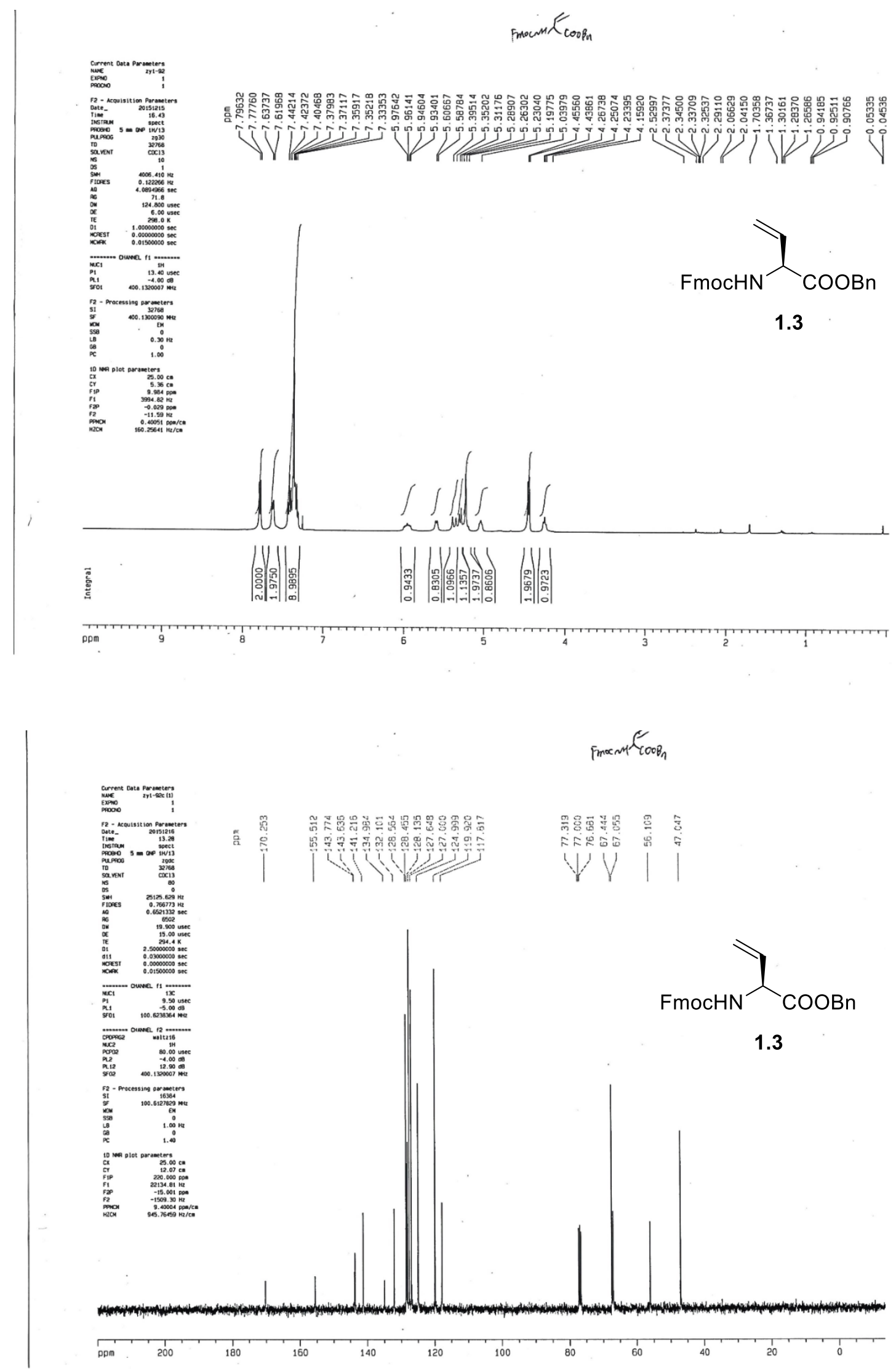



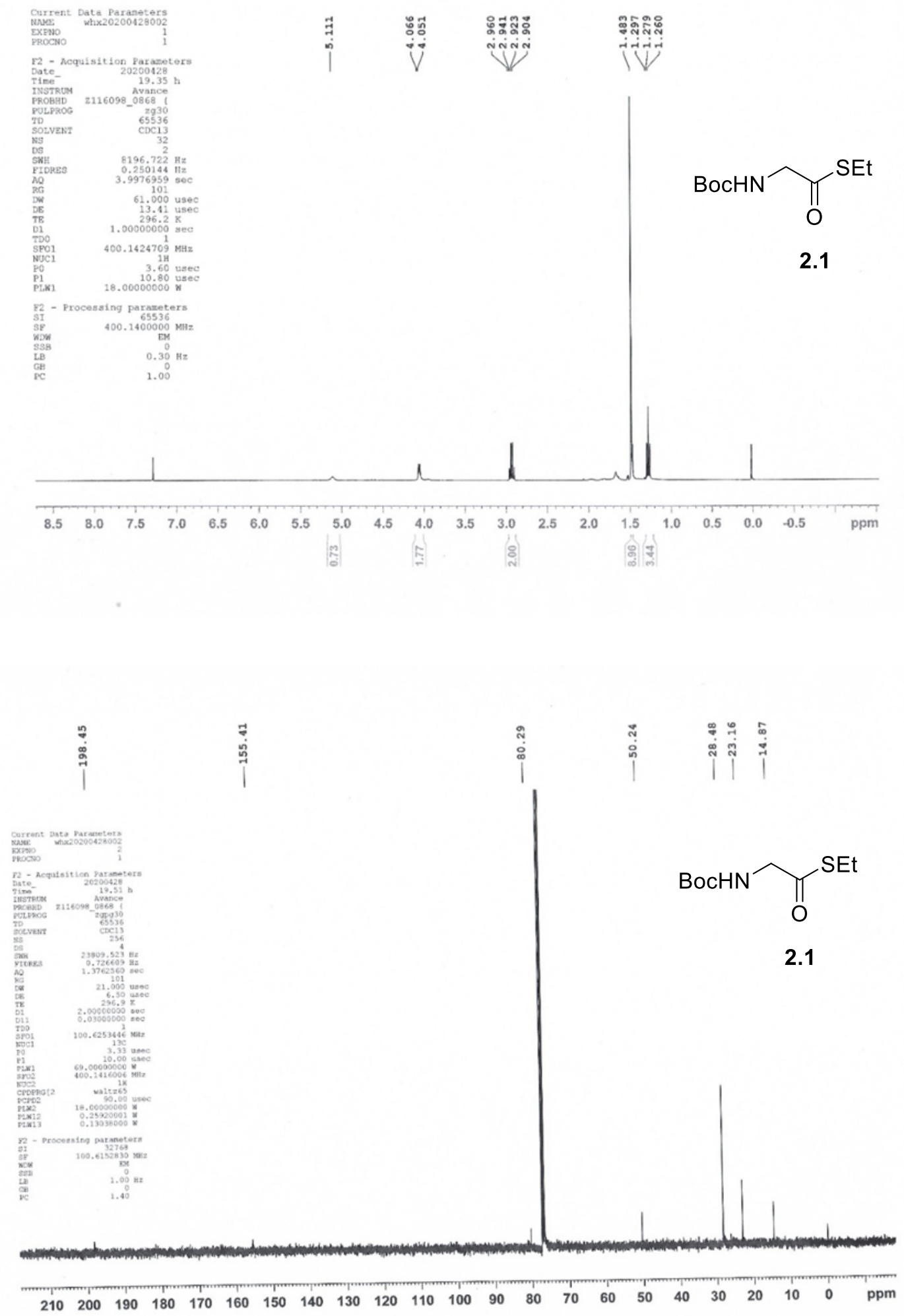

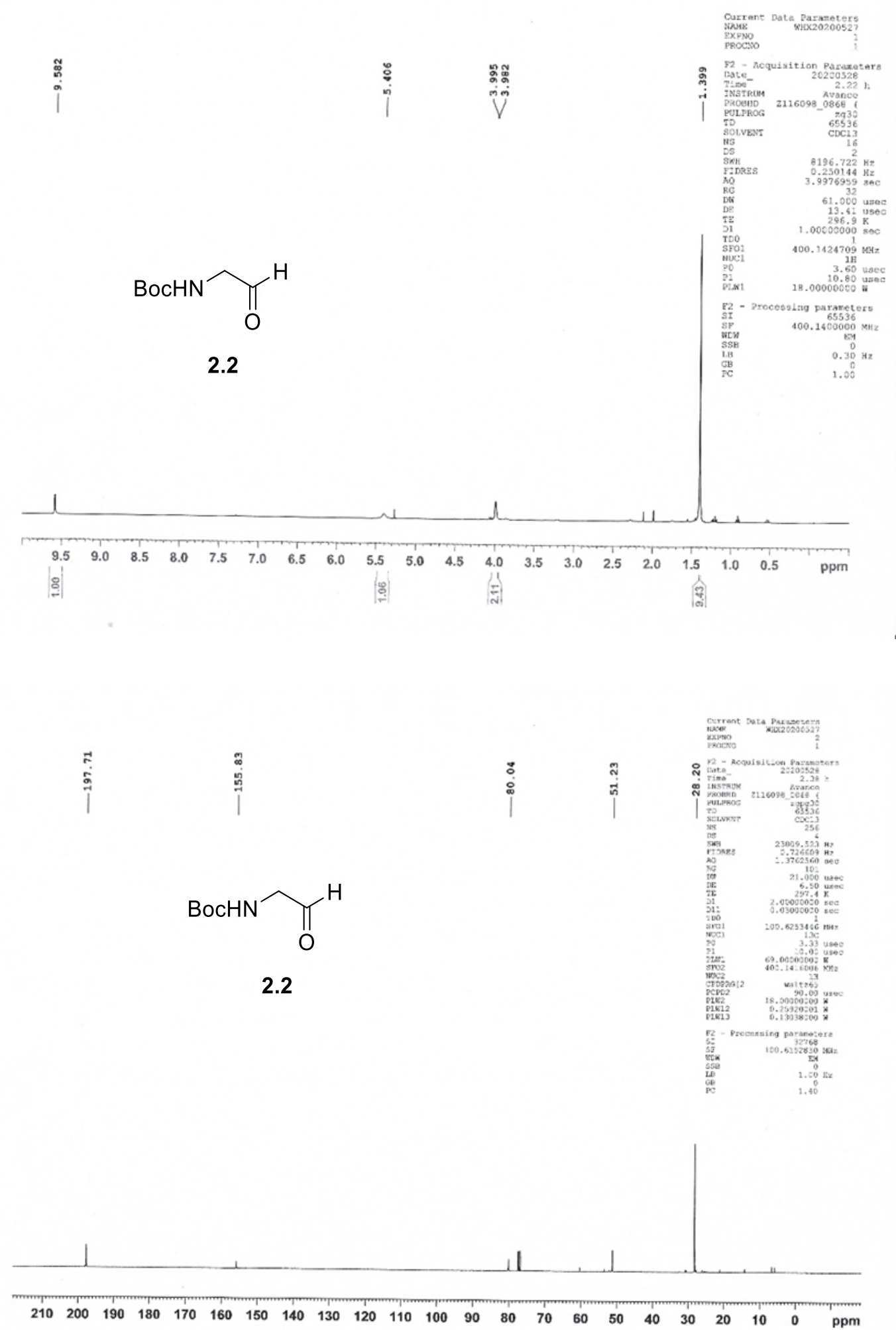

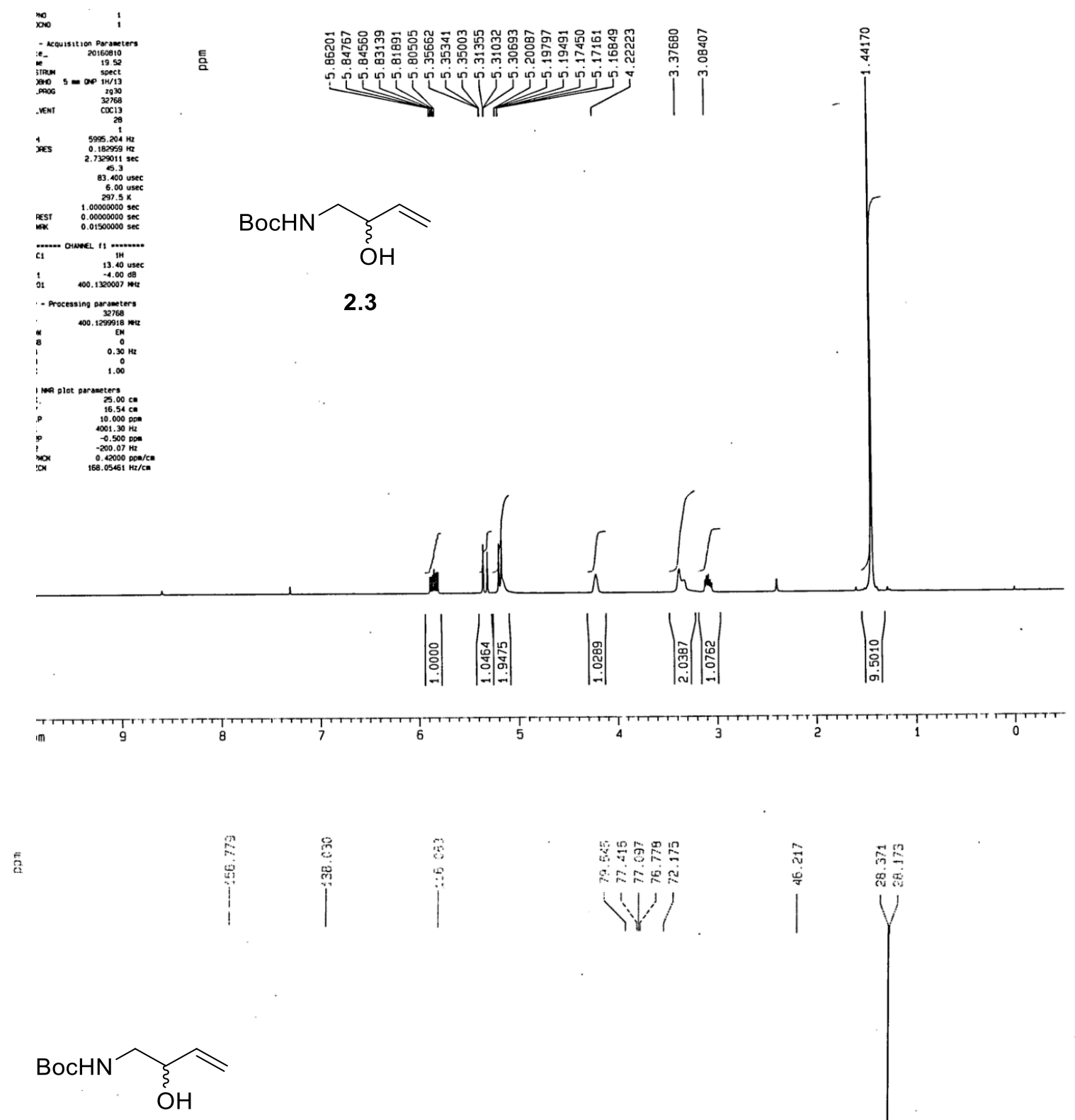

2.3

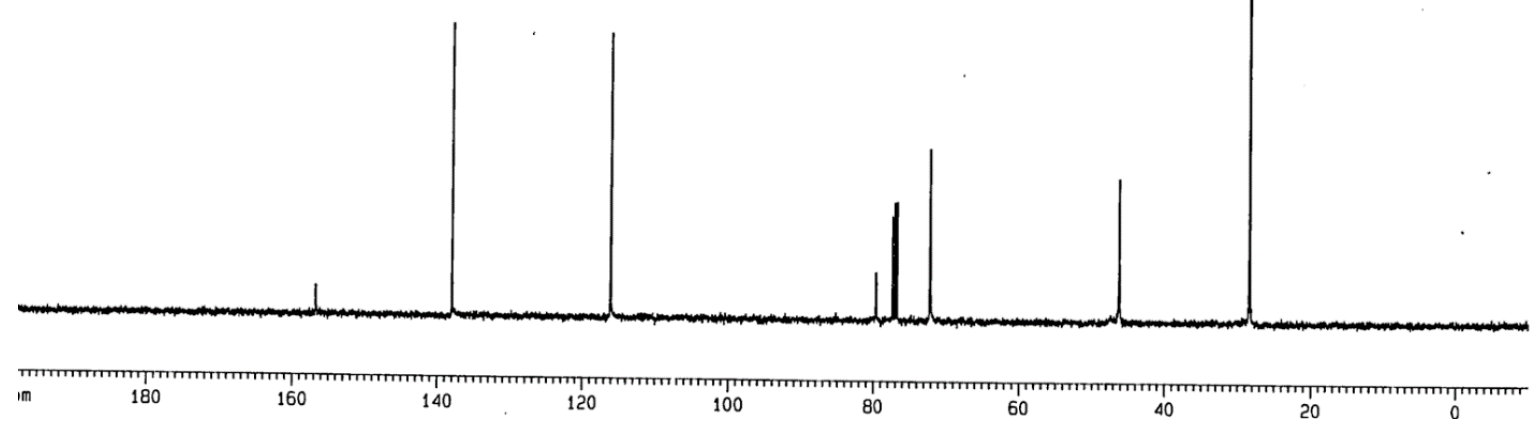



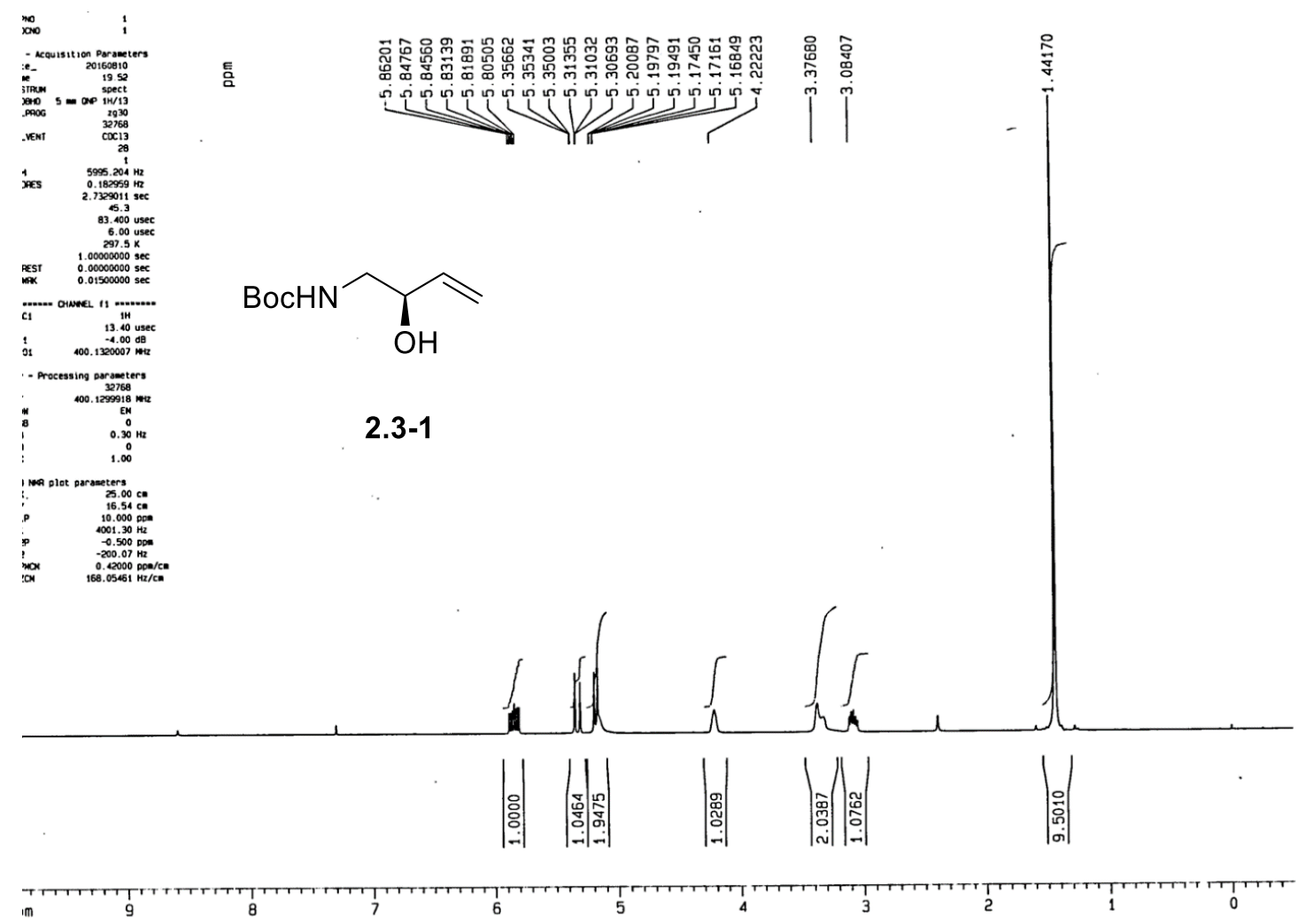

흠

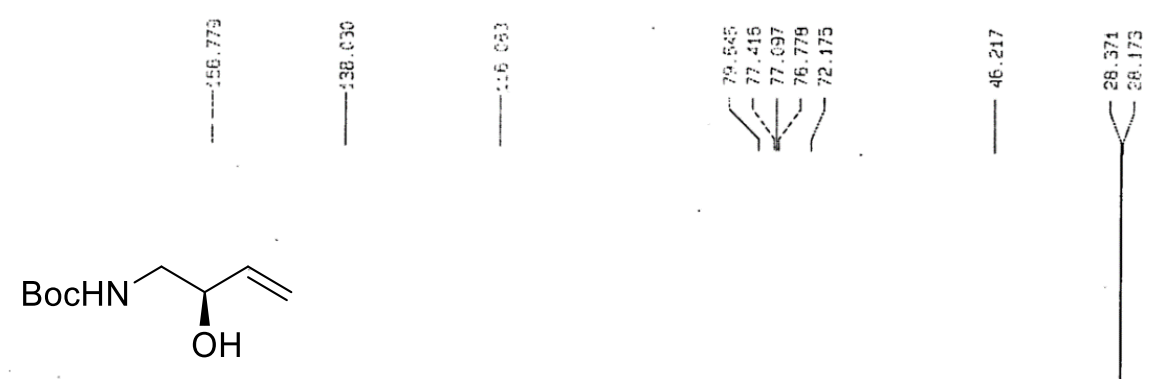

2.3-1

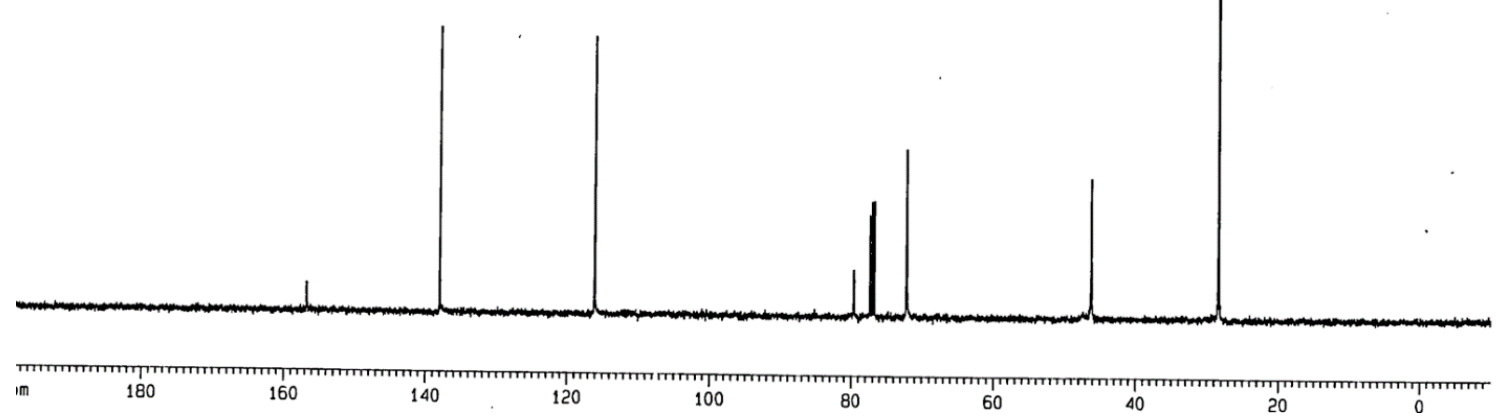



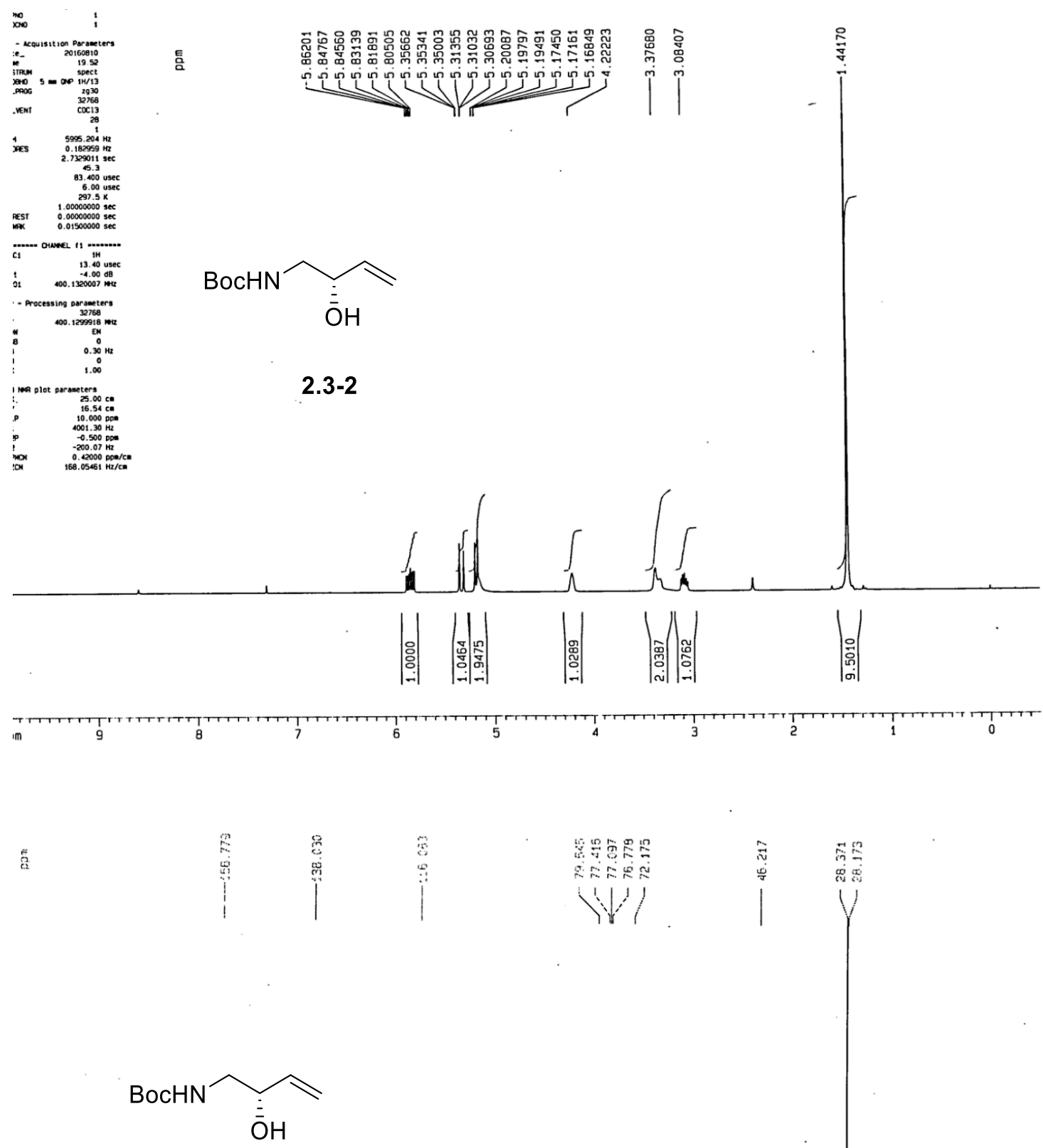

2.3-2
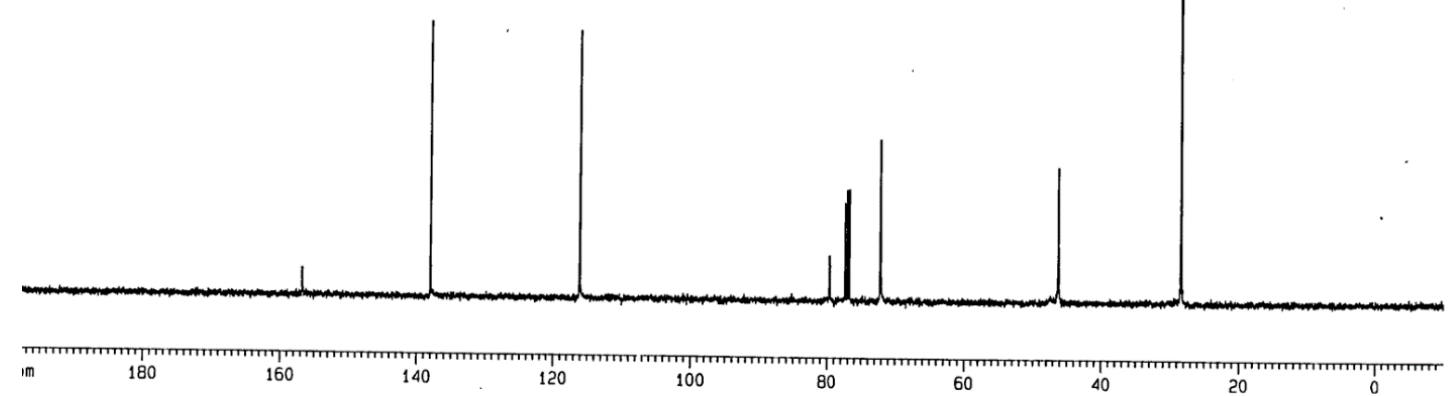

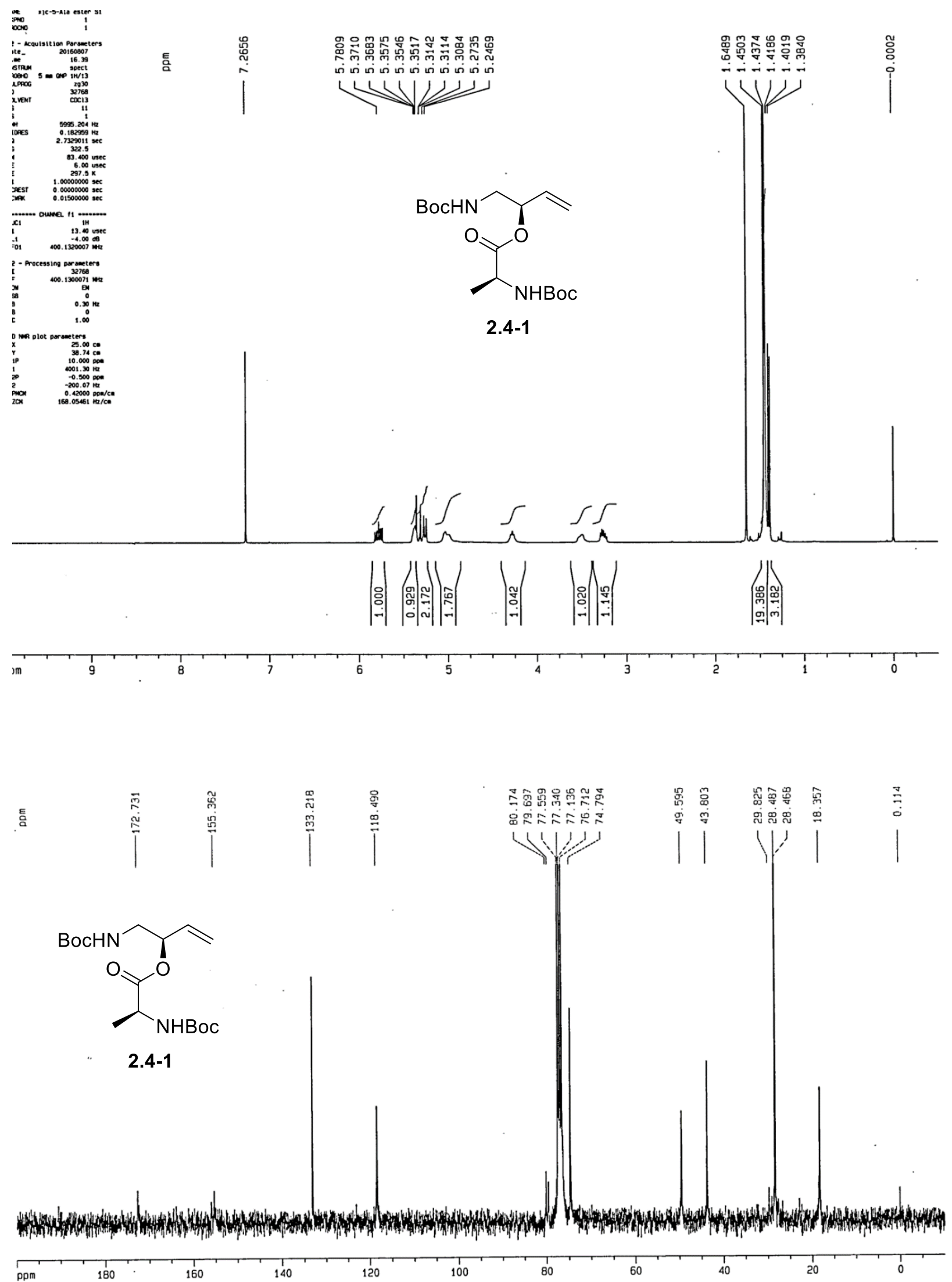


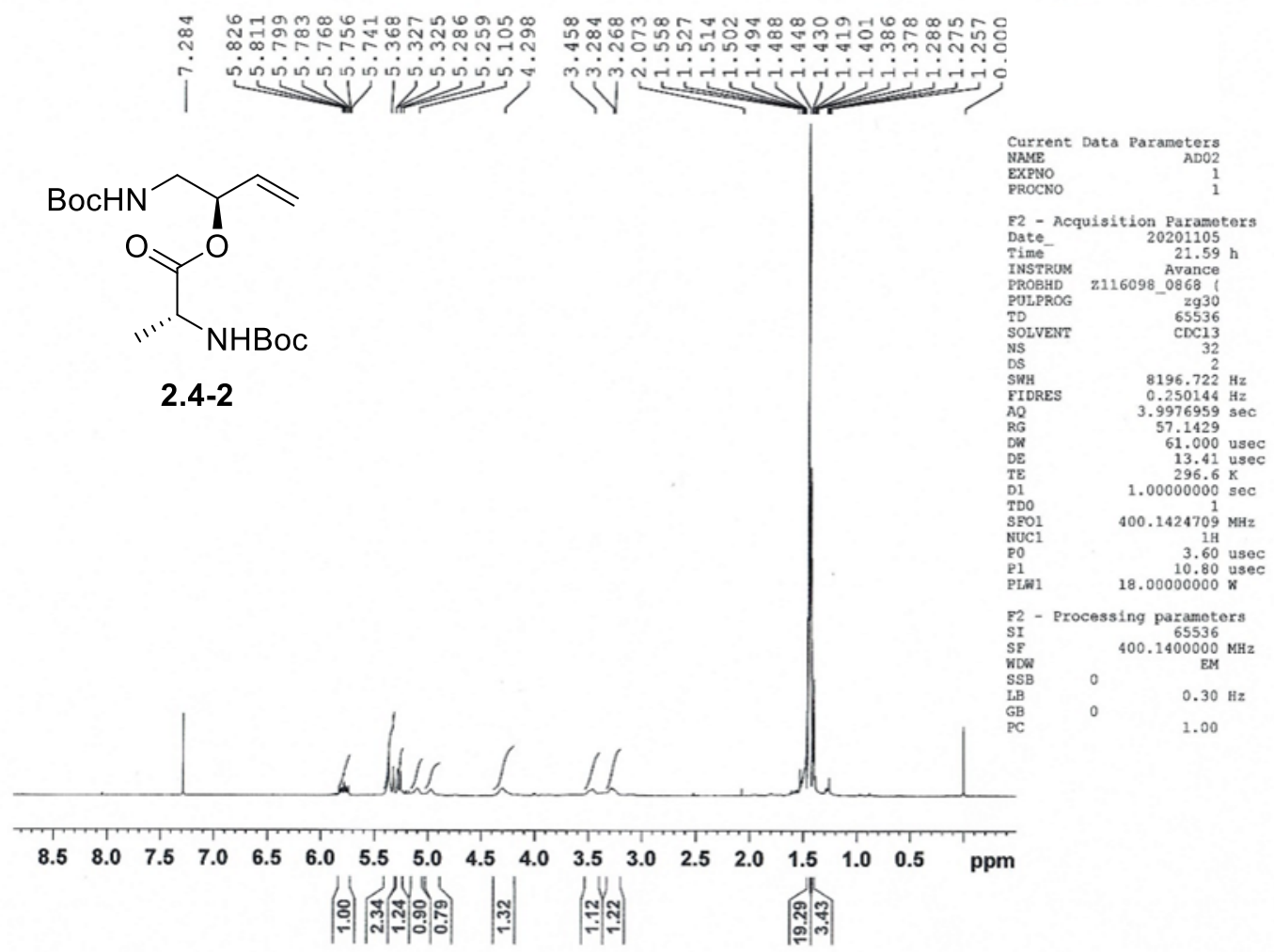

ถ

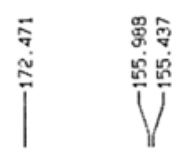

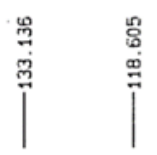

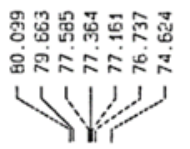

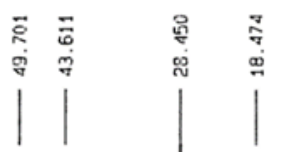

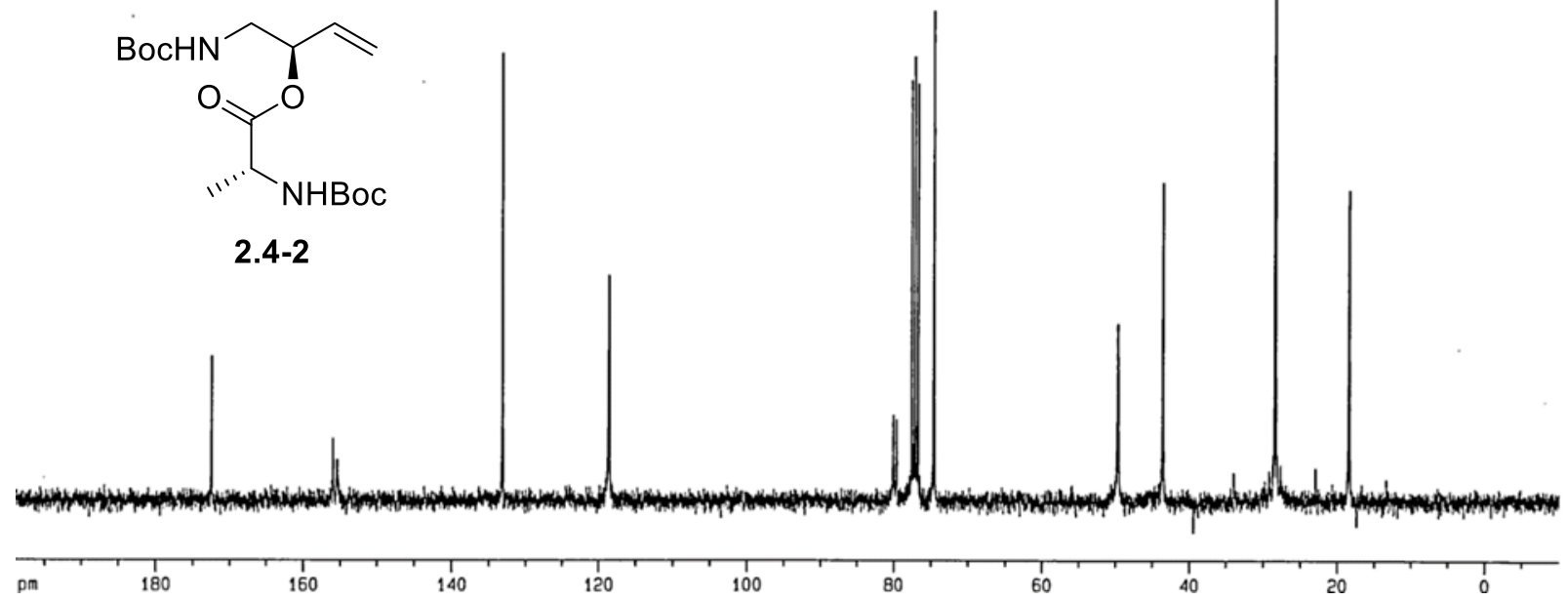



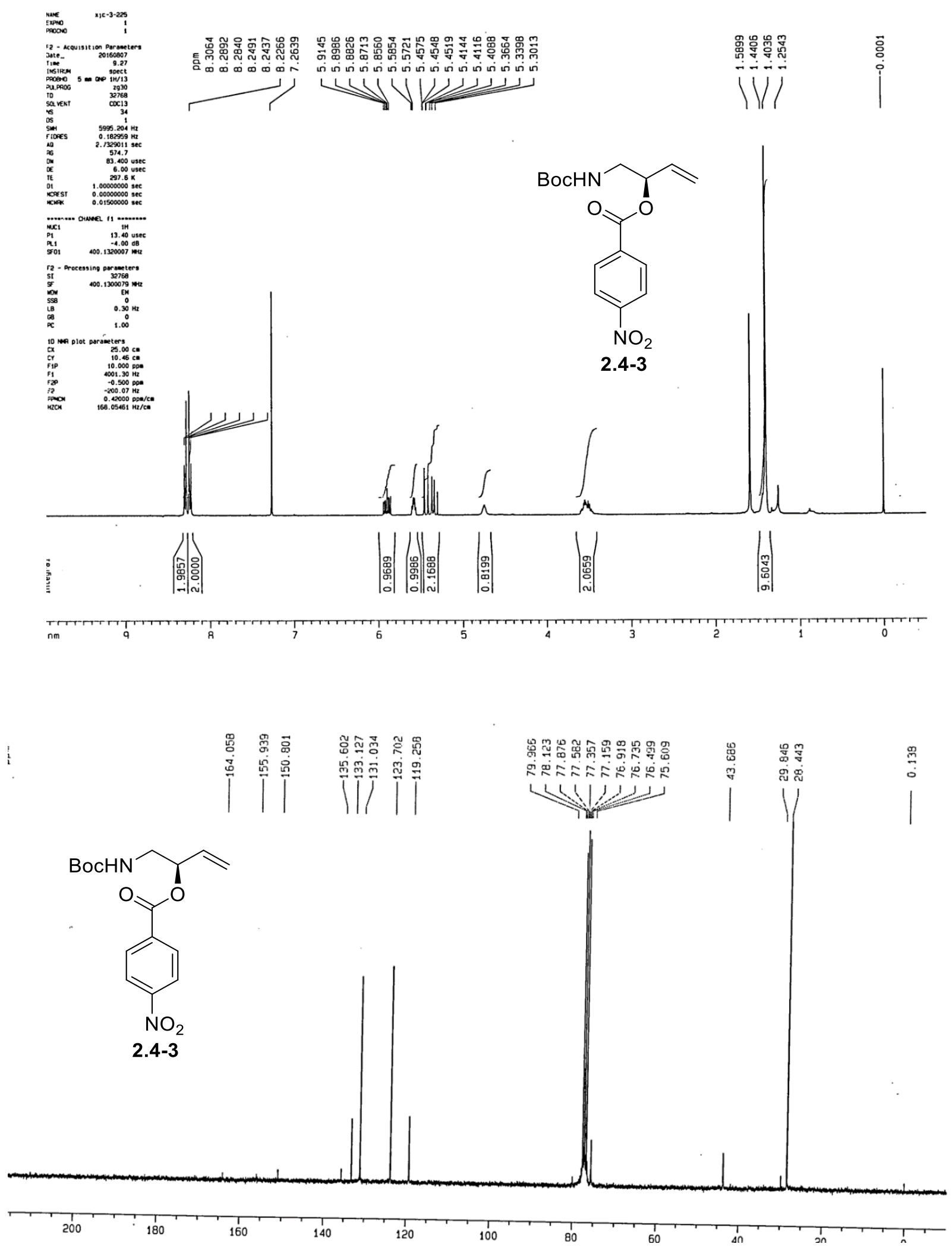


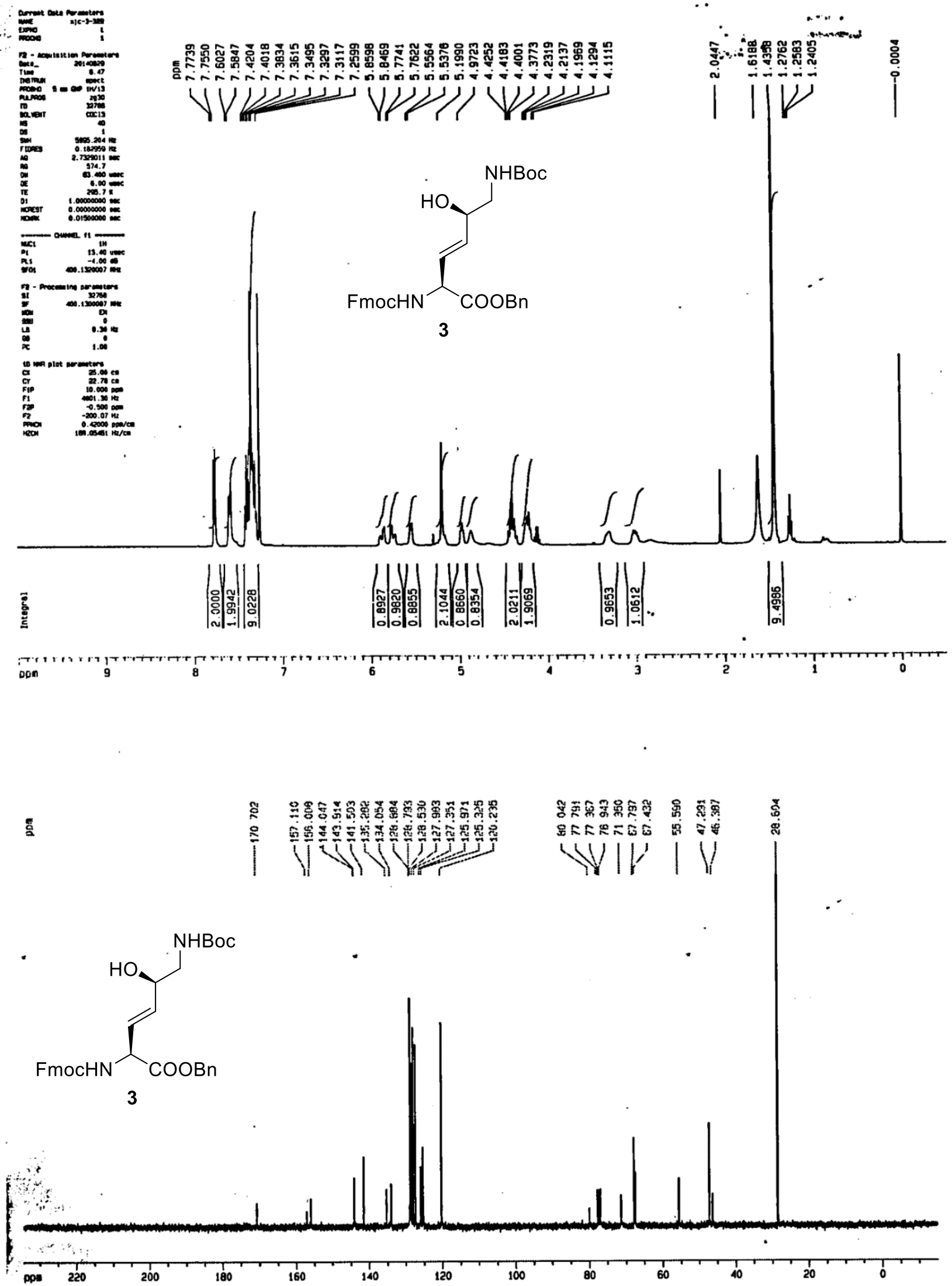




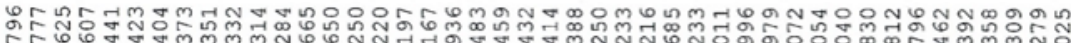

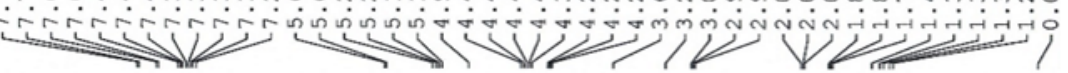

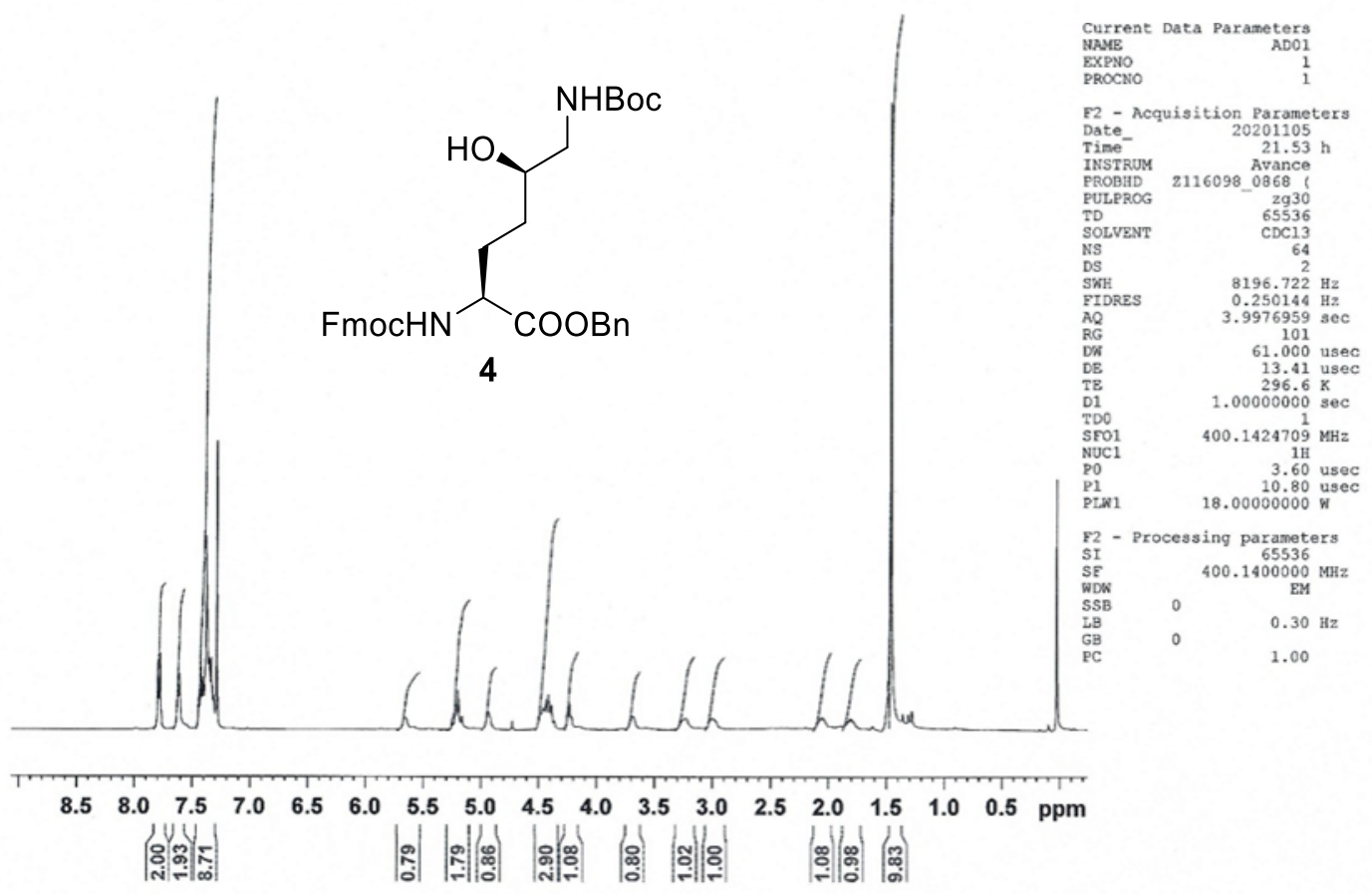

$\Xi$
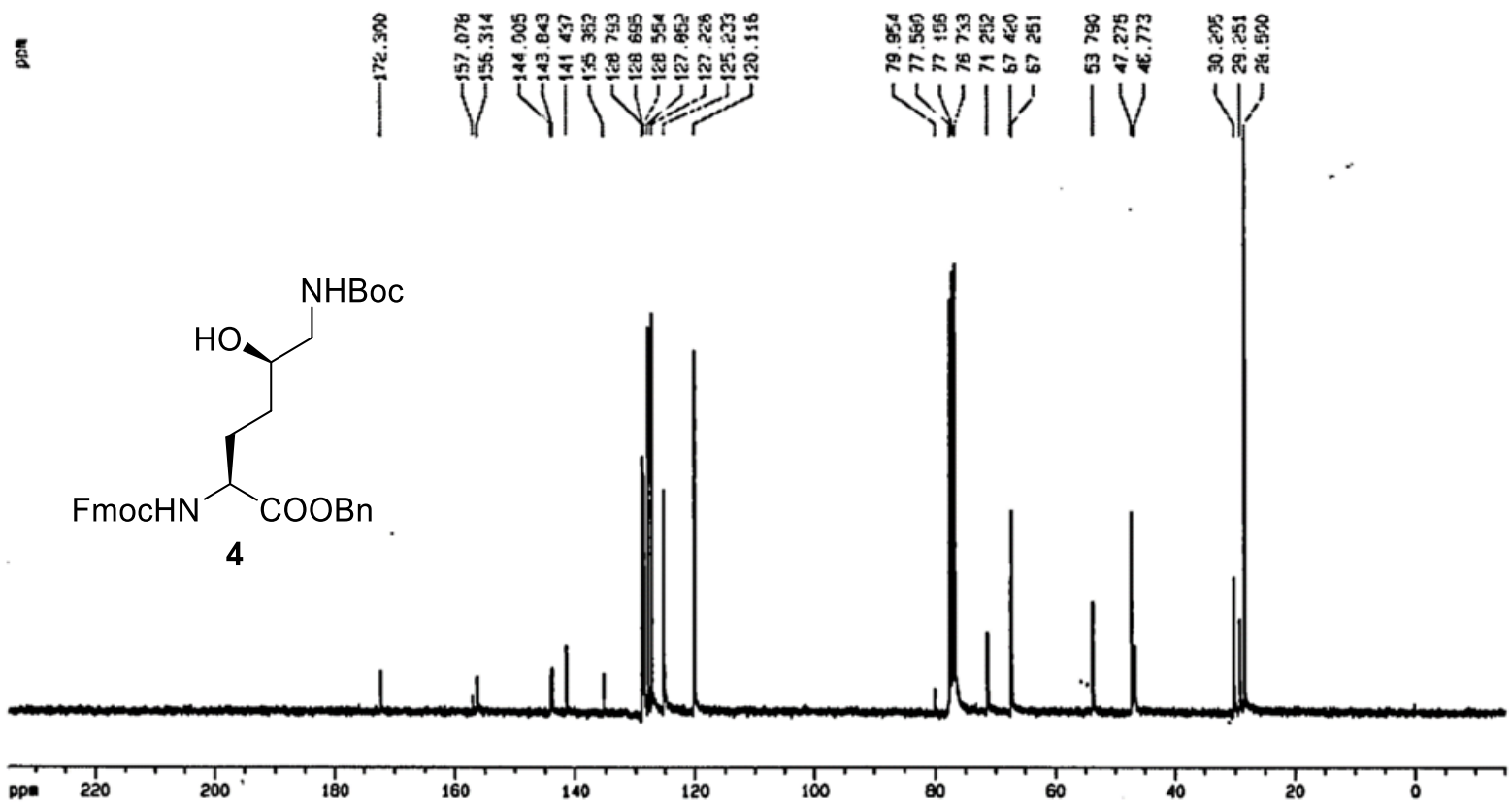

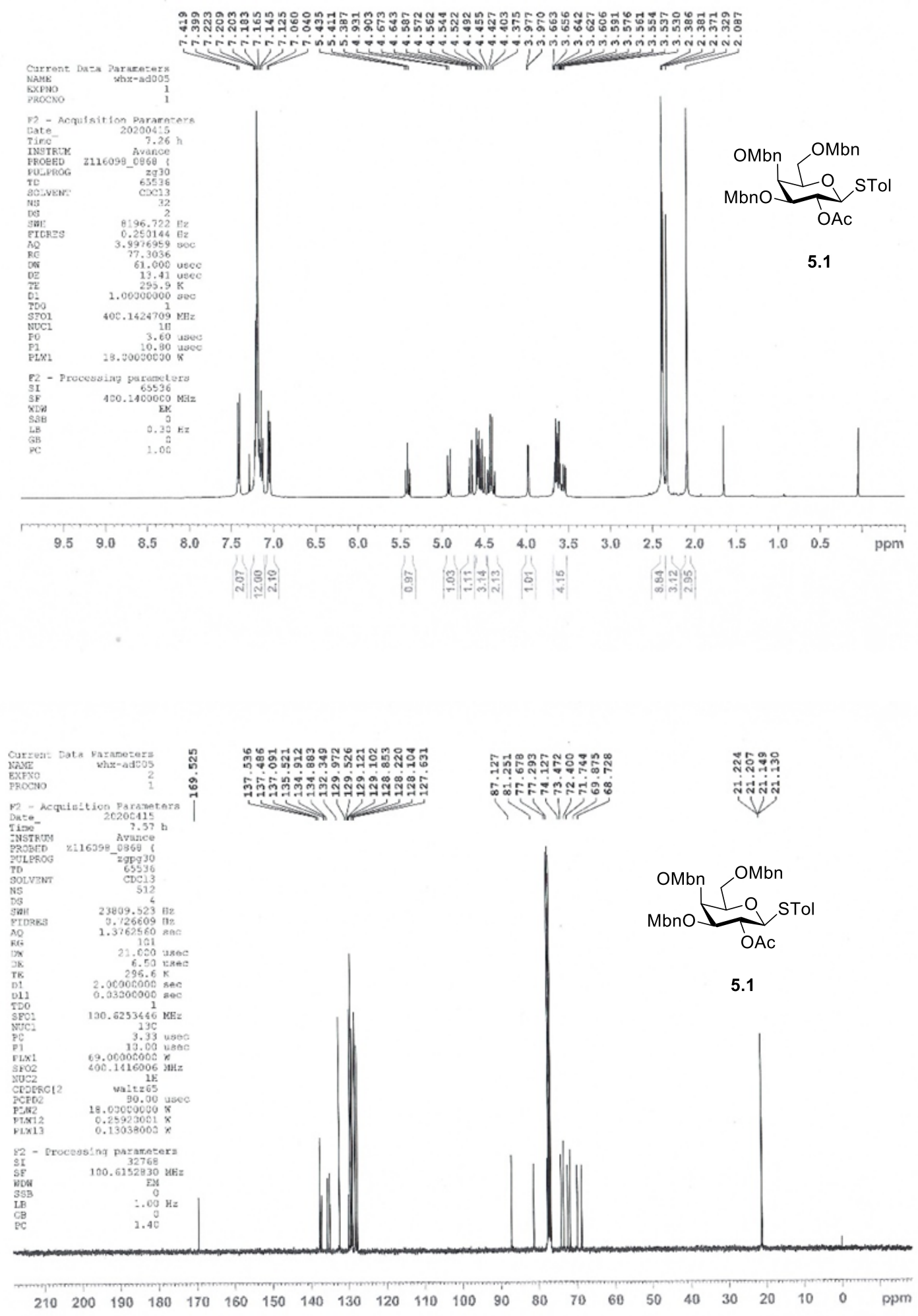


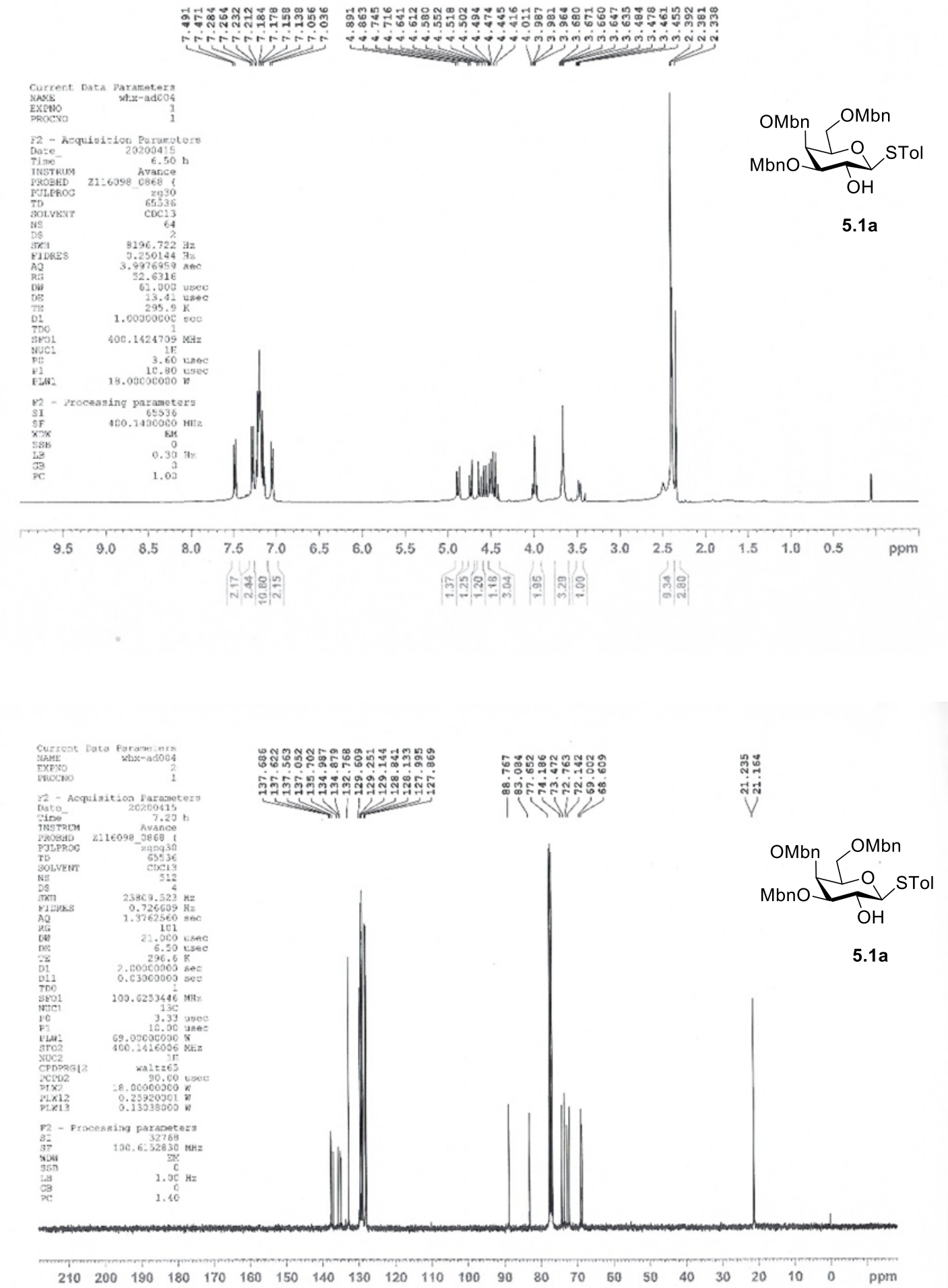



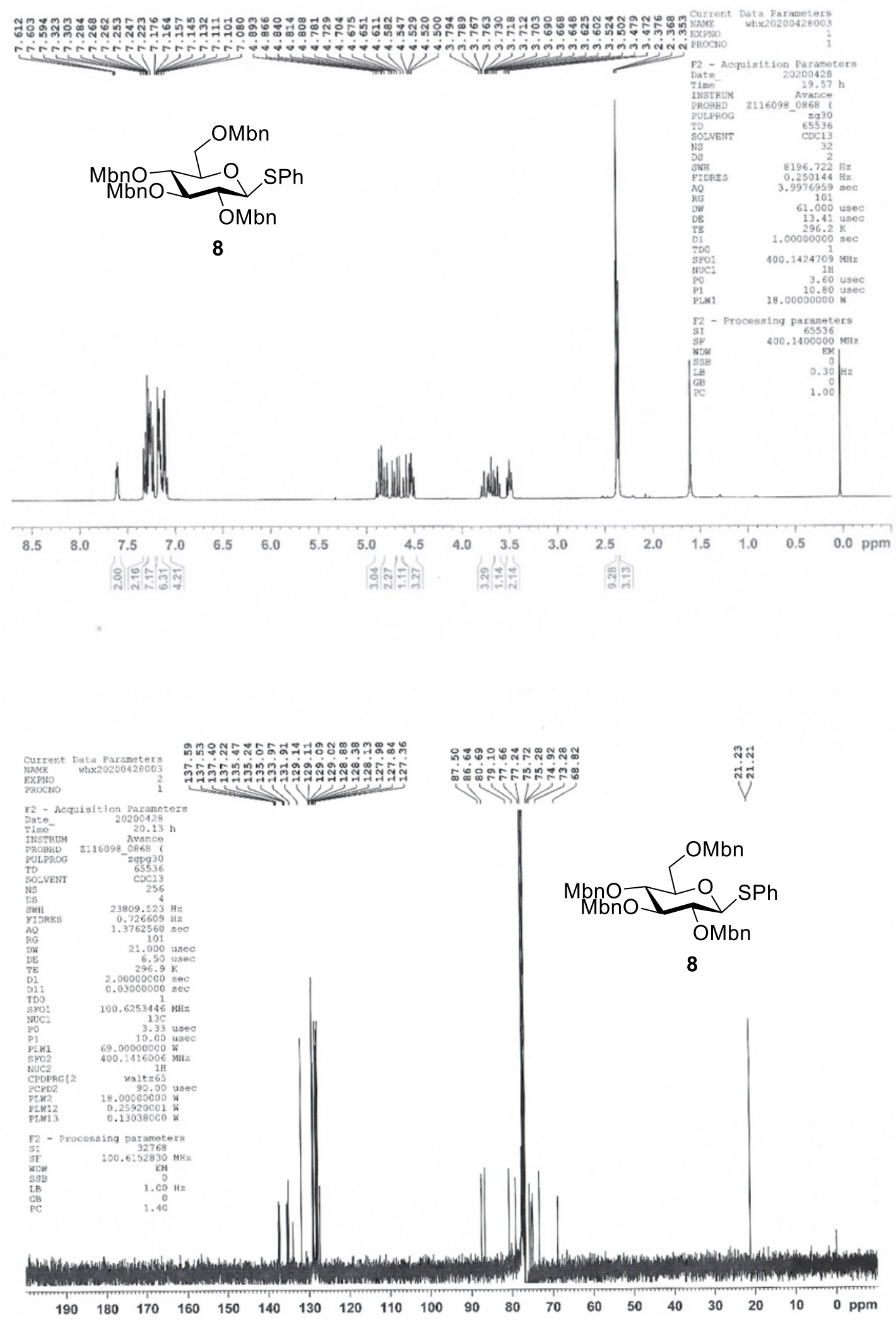

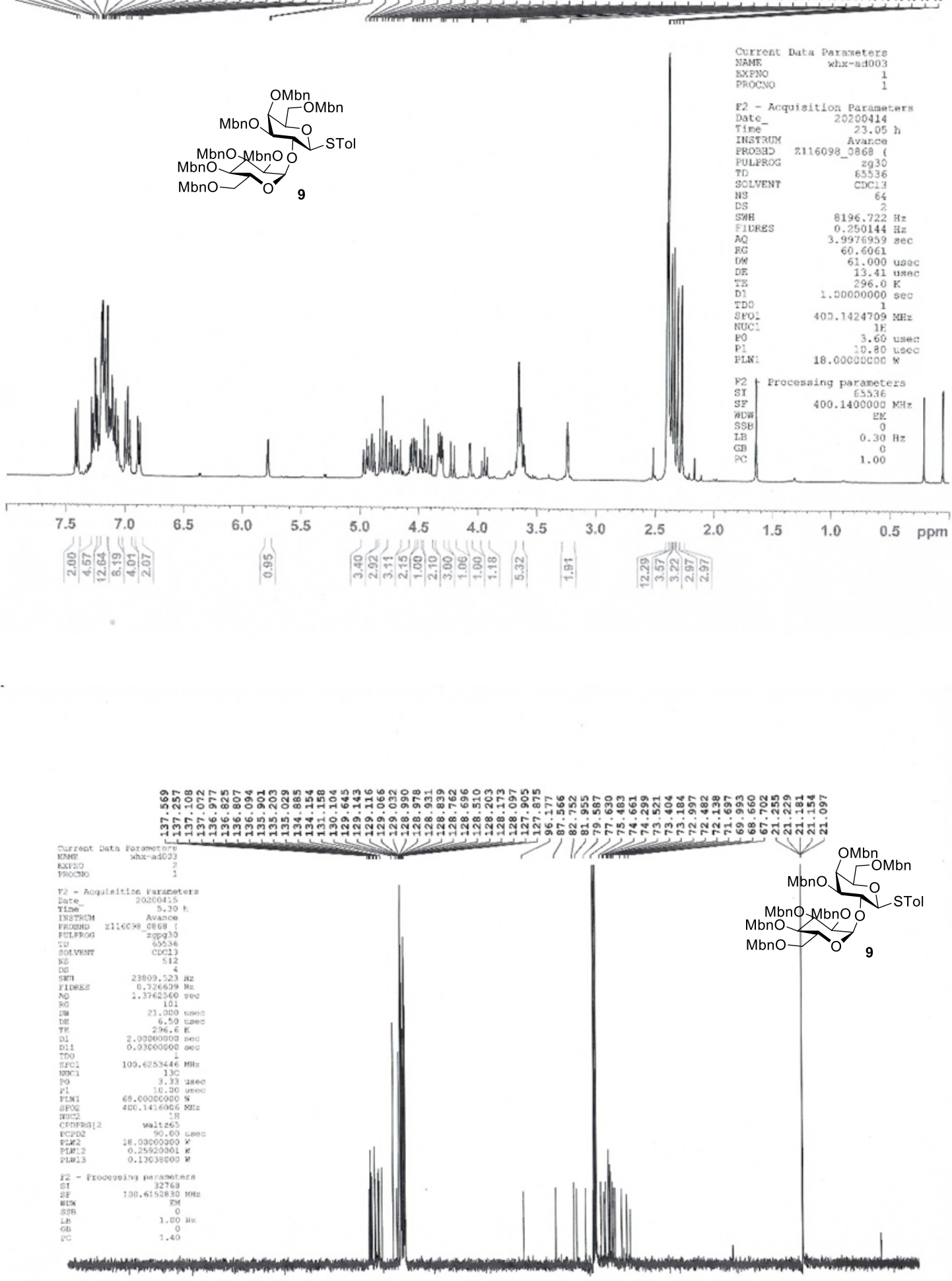

$\begin{array}{llllllllllllllllllllll}210 & 200 & 190 & 180 & 170 & 160 & 150 & 140 & 130 & 120 & 110 & 100 & 90 & 80 & 70 & 60 & 50 & 40 & 30 & 20 & 10 & \mathrm{ppm}\end{array}$ 

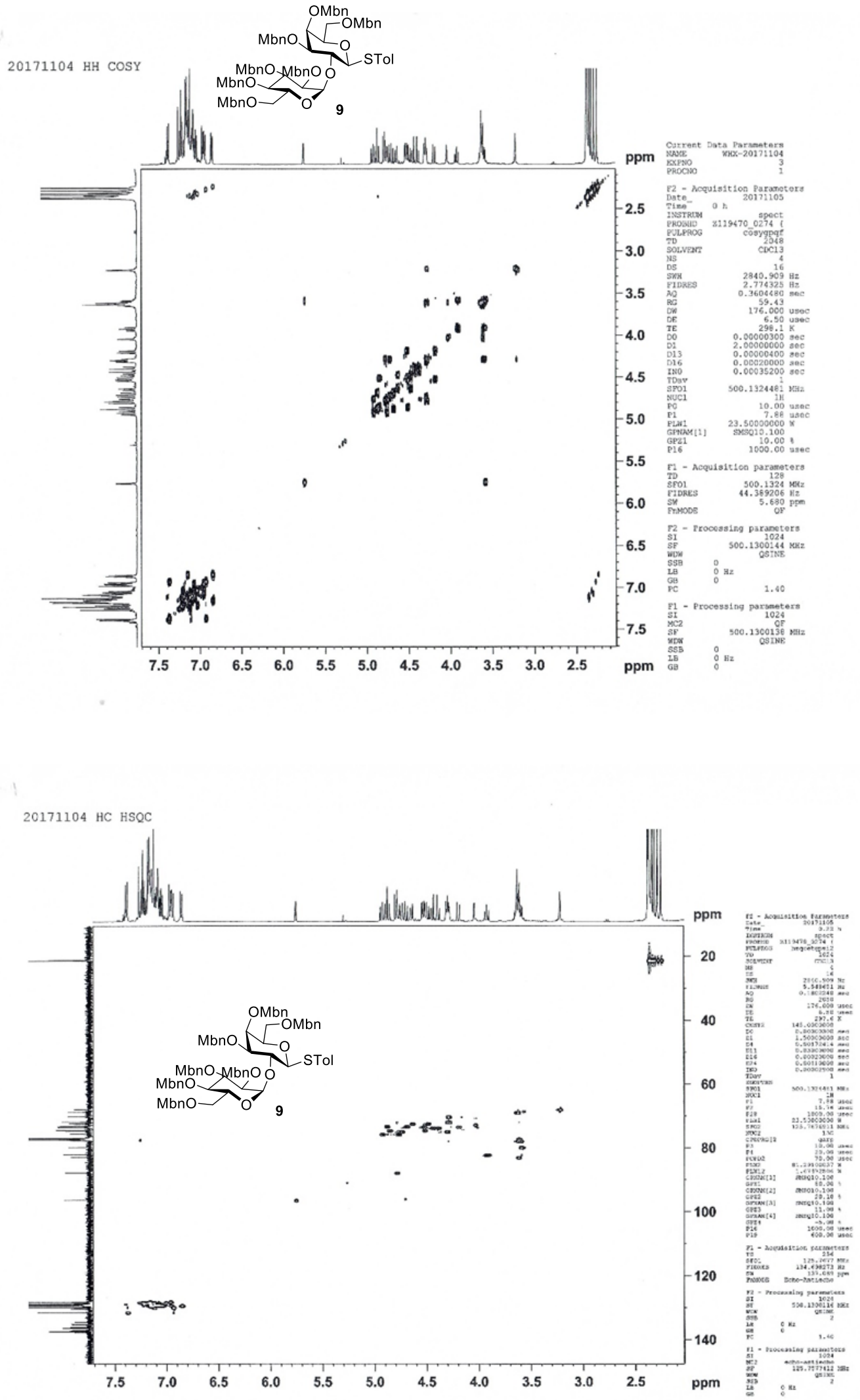


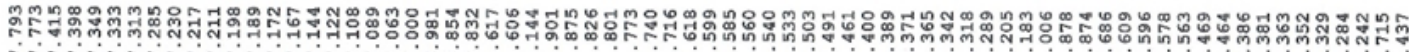

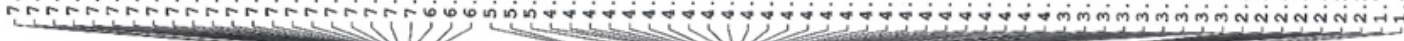

Current Data Parameters
NAME
EXPNO
PROCNO

F2 - Acquisition Parameters

F2 - Acquisition Parameters
Date- 20200414 h
Time

Time
INSTROM
PROBHD 21160980868

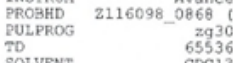

$\begin{array}{lr}\text { TD } & 2959 \\ \text { SOLVENT } & 65536 \\ \text { NS } & 64 \\ \text { DS } & 6413 \\ \text { SNH } & \end{array}$

$\begin{array}{lr}\text { DS } & 64 \\ \text { SWH } & 8196.722 \\ \text { FIDRES } & 0.250144 \mathrm{~Hz} \\ \text { HO } & 3.997699\end{array}$

$\begin{array}{ll}\text { CODRES } & 0.250144 \mathrm{~Hz} \\ \text { RG } & 3.9976959 \mathrm{sec} \\ \text { RG } & 75.4831\end{array}$

61.000 usec

13.41 use
$295.9 \mathrm{~K}$

$\begin{array}{ll}\mathrm{TE} & 1.00000000 \mathrm{sec} \\ \mathrm{D} 1 & 295.9 \mathrm{~kg} \\ \mathrm{TDO} & 400.1424709 \mathrm{2} \mathrm{MHz}\end{array}$

$\begin{array}{lr}\text { SFl } & 400.1424709 \mathrm{MHz} \\ \text { SFUC1 } & 1 \mathrm{H} \\ \text { NO } & 3.60 \text { use }\end{array}$

$\begin{array}{lr}\text { P0 } & 3.60 \text { use } \\ \text { P1 } & 10.80 \text { use }\end{array}$

P2 - Processing parameters

$\begin{array}{ll}S I & 6536 \\ S F & 400.140000\end{array}$

$\begin{array}{lc}\text { KDN } / & \mathrm{EM} \\ \text { SSB } & 0 \\ \mathrm{LB} & 0.30 \mathrm{~Hz} \\ \mathrm{~GB} & 0 \\ \mathrm{PC} & 1.00\end{array}$
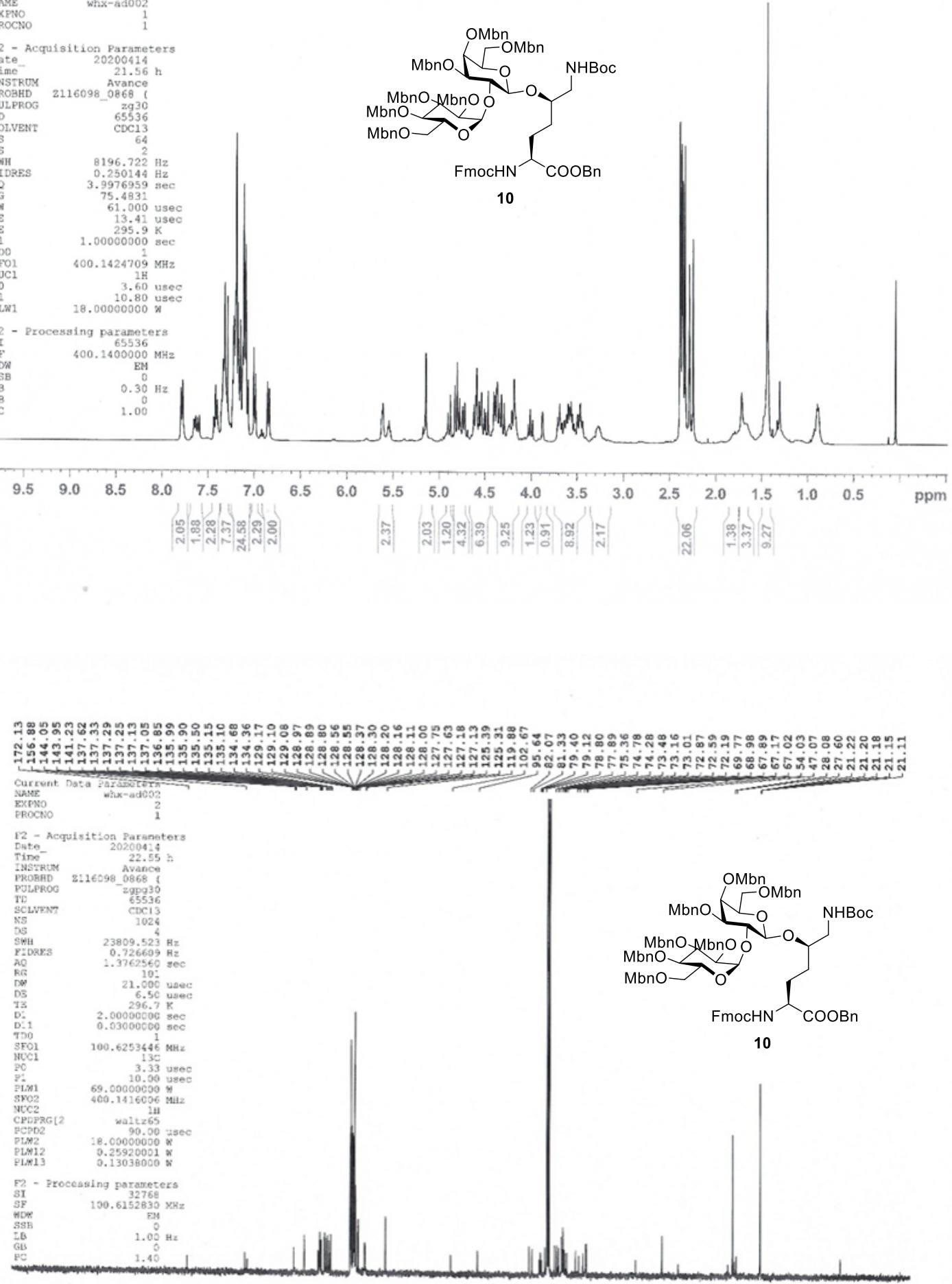

$\begin{array}{llllllllllllllllllllll}210 & 200 & 190 & 180 & 170 & 160 & 150 & 140 & 130 & 120 & 110 & 100 & 90 & 80 & 70 & 60 & 50 & 40 & 30 & 20 & 10 & 0\end{array}$ 

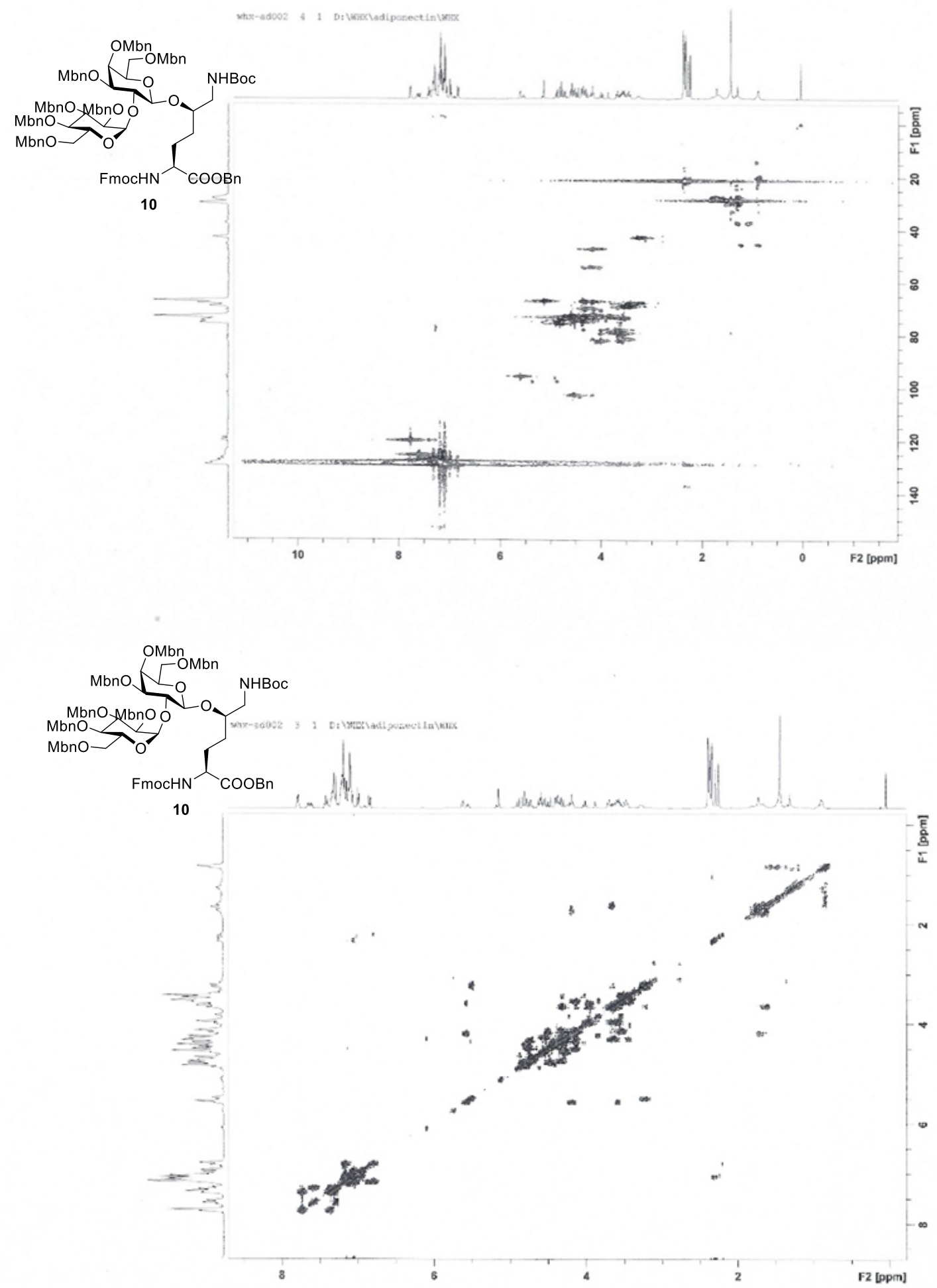


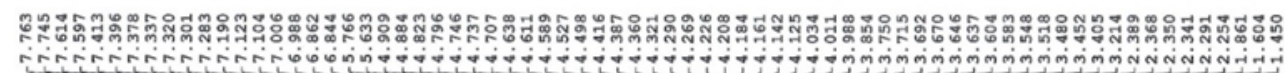
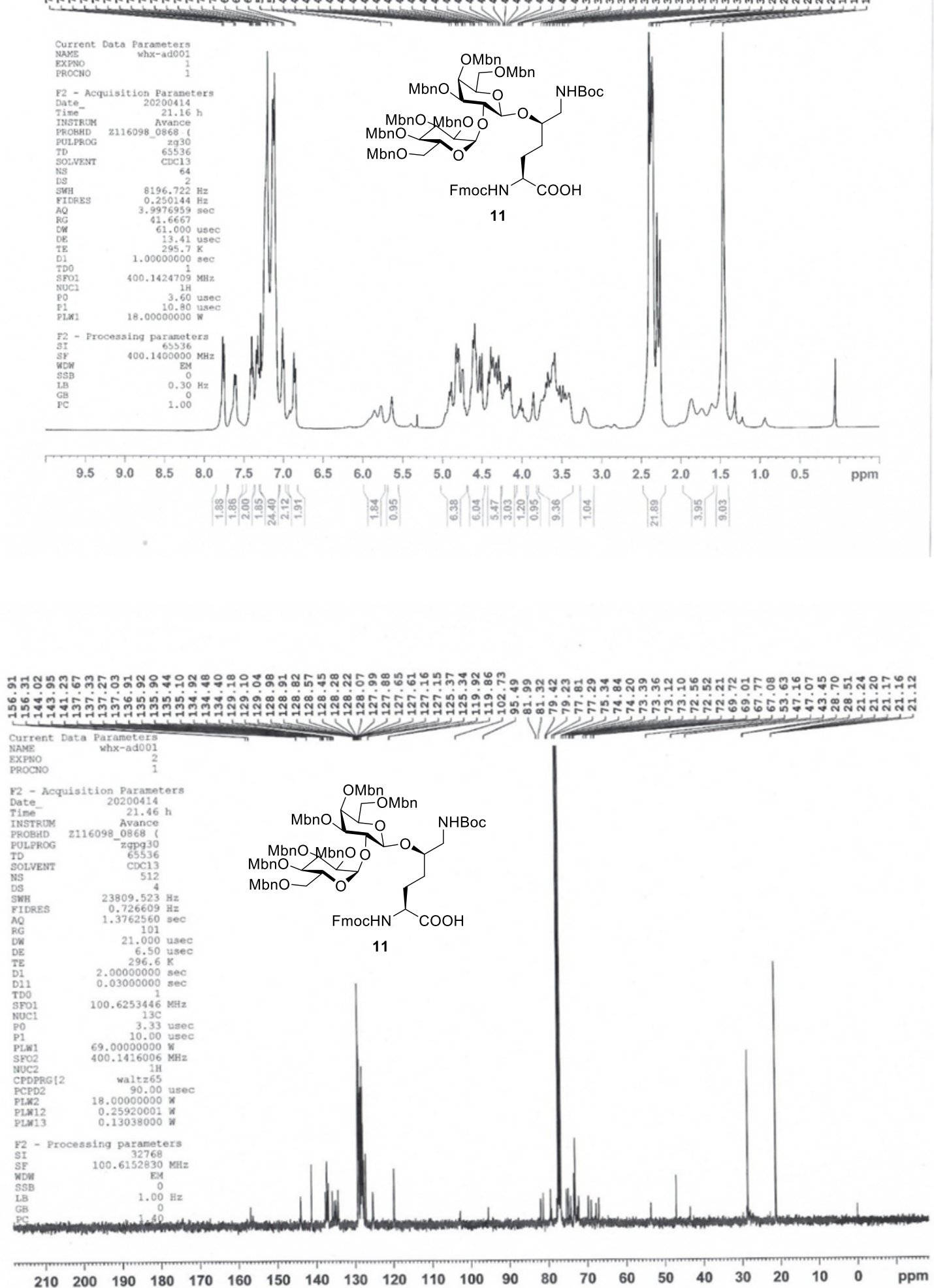

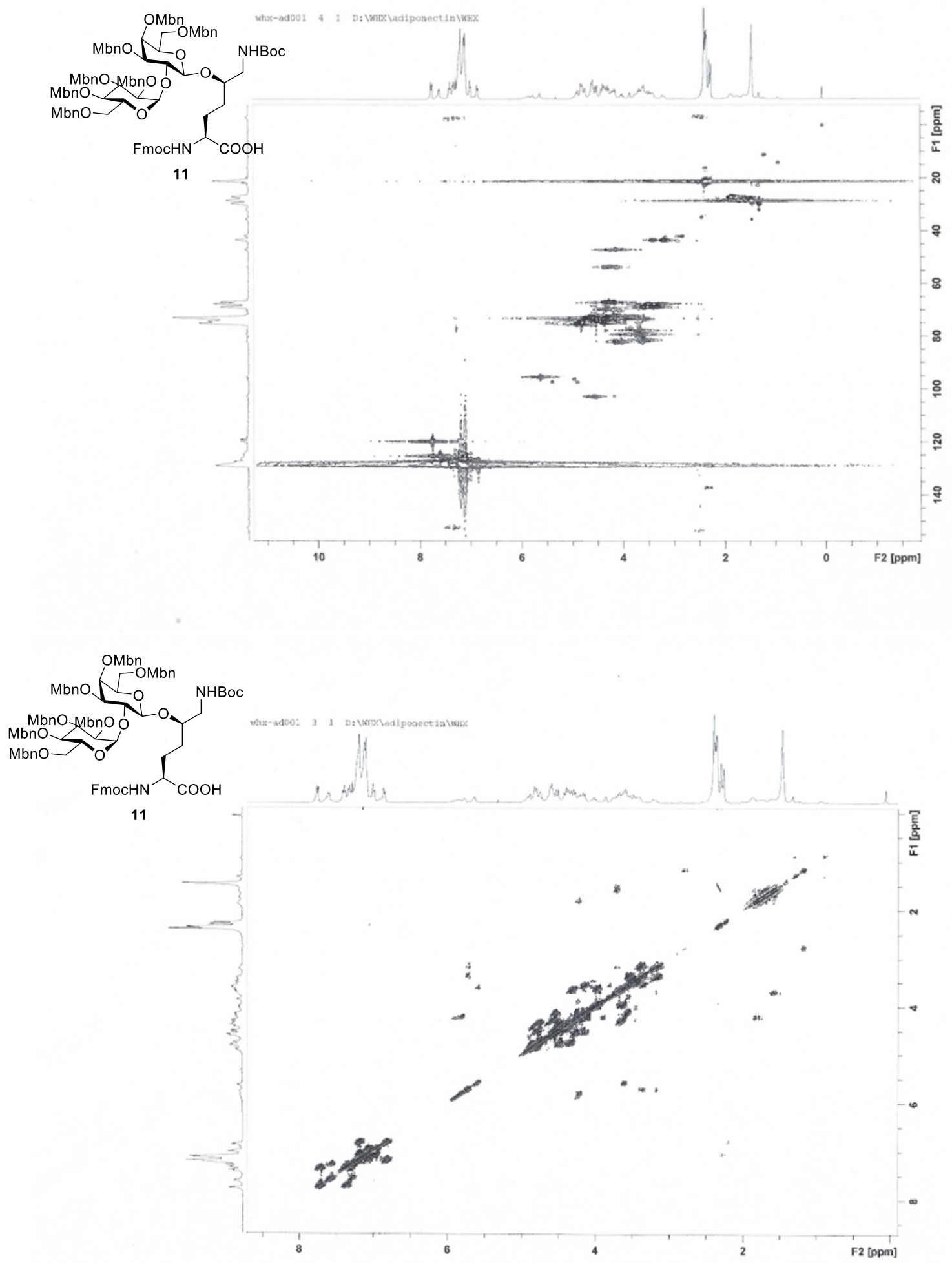